\title{
BUDDHISM IN THE SHADOW OF BRAHMANISM
}

\author{
by
}

Johannes Bronkhorst 
I. INTRODUCTION: BUDDHISM BEFORE THE NEW BRAHMANISM

The original context

Interactions

Imperial help

\section{BRAHMANISM}

II.1 The new Brahmanism

II. 2 The spread of Sanskrit

II.3 The brahmanical colonization of the past

II.4 The brahmanization of borrowed features

\section{BUDDHISM CONFRONTED WITH BRAHMANISM}

III.1 A courtly challenge

III. 2 Science and religion in classical India

III.3 A new language

Appendix to chapter III.3: Jainism, Mathurā and Sanskrit

III.4 Buddhist Hybrid Sanskrit, the original language

III.5 Buddhism sanskritized, Buddhism brahmanized

III.6 Philosophical encounters

III.7 The relics of the Buddha

Relic worship

What happened to the body of the Buddha?

Appendix to chapter III.7: What happened to Mahāvira's body?

III.8 Adjustment to political reality

$\underline{\text { References }}$

$\underline{\text { Abbreviations }}$

$\underline{\text { Index }}$ 


\section{INTRODUCTION: BUDDHISM BEFORE THE NEW BRAHMANISM}

\section{The original context}

Buddhism, we are often told, was a reaction against vedic Brahmanism. Vedic Brahmanism is the religion that finds expression in the Veda, an immense corpus of texts. Vedic Brahmanism, we are made to understand, is much older than Buddhism and was indeed the dominant religion in northern India, including the area in which Buddhism arose.

I do not share this opinion. I do not deny that many vedic texts existed already, in oral form, at the time when the Buddha was born. However, the bearers of this tradition, the Brahmins, did not occupy a dominant position in the area in which the Buddha preached his message, and this message was not, therefore, a reaction against brahmanical thought and culture.

I have argued this position at length in a book - Greater Magadha - that came out in 2007. In this introduction no full justice can be done to the arguments there presented. In order to understand what follows, it is yet necessary to be acquainted with some of its findings. These will here be briefly reviewed. Further information, arguments and references can be found in Greater Magadha. ${ }^{1}$

We do not know exactly when the historical Buddha died. For a long time Buddhist scholars thought they knew. Most Western scholars agreed upon a date close to the year 480 BCE. Few scholars still accept this date. A study in which

\footnotetext{
${ }^{1}$ Geoffrey Samuel, in a recent publication (2008: $48 \mathrm{ff}$.; also $61 \mathrm{ff}$.) which however refers back to an earlier unpublished manuscript of Thomas Hopkins, presents on the basis of primarily archaeological evidence a notion of "two cultural processes moving more or less concurrently toward the use of iron and urbanization from two separate sources: one in the eastern Punjab, Rajasthan, the Doab, and northward to the Himalayas west of $81^{\circ}$ longitude, identified with the Painted Grey Ware culture and the Aryans; the other based on the Eastern Gangetic culture with its apparent initial connection to the Malwatype cultural complex - in the region of Patna, in the valleys of the Ghagara and Gandak rivers northwest of Patna, and westward to the region around the lower Doab." The two areas correspond to those distinguished in Greater Magadha. To the list of aspects in which the two "worlds" may have differed from each other, Samuel (p. 89 ff.) adds gender attitudes. Samuel is no doubt right in concluding (p. 343): "It seems to me that an initial tension between the values of the vedic society of Kuru-Pañcāla and those of the Central Gangetic region can be sensed through much of the early development of Indic religions, and in various ways continues into much later times."
} 
many participated has not led to a result upon which scholars agree. ${ }^{2}$ However, many of them approve of a date not too distant in time from the year 400 BCE, give or take a few decades in either direction. $400 \mathrm{BCE}$ means before the incursion into India by Alexander of Macedonia in the second half of the fourth century BCE, also before the creation of a large empire in northern India by the Nandas and the Mauryas presumably from the middle of the fourth century BCE onward, and much before the Sanskrit grammarian Patañjali, whom we know to have lived around the year $150 \mathrm{BCE}$.

This Sanskrit grammarian provides us with some interesting information about the heartland of Brahmanism in his time. He calls it "land of the Āryas" (āryāvarta), and situates in essentially in the Ganges plain, between the Thar desert in the west and the confluence of the rivers Ganges (Gangā) and Jumna (Yamunā) in the east. ${ }^{3}$ Exactly the same expression is used again in the Manava Dharmaśāstra, a text that was composed three to four centuries later. ${ }^{4}$ Here, however, the "land of the Āryas" (āryāvarta) extends from the eastern to the western sea, and is therefore much larger than Patañjali's Āryāvarta. This suggests that an important change had taken place between the second century $\mathrm{BCE}$ and the second or third century CE: The Brahmins of the second century BCE looked upon the eastern Ganges valley as more or less foreign territory, the Brahmins of the second or third centuries CE looked upon it as their land.

This change concerns the eastward spread of Brahmanism. This should not be confused with the move eastward of individual Brahmins, even though the two are connected. Brahmins carry the claim of being superior to other members of society. A region that has a number of Brahmins living in it but which does not recognize the Brahmins' claim to superiority is not brahmanized. It becomes

\footnotetext{
${ }^{2}$ Bechert, 1986; 1991; 1992; 1995; 1997.

${ }^{3}$ Interestingly, the jaina text (Brhat-)Kalpasūtra also speaks of Āryan countries, in the following manner: "Monks or nuns may wander eastward as far as Anga-Magadha, southward as far as Kosambī, westward as far as Thūṇā and northward as far as Kuṇāla. They may wander thus far, (for) thus far there are Āryan countries, but not beyond unless the Dhamma flourishes there." (Bollée, 1998: xxiv). Even though it is difficult to identify Thūnā, it seems likely that the jaina "Āryan countries" lay to the east of the brahmanical "land of the Āryas".

${ }^{4}$ See Bronkhorst, forthcoming, for a discussion of "Manu"'s date.
} 
brahmanized when this claim comes to be accepted. Until that time the region concerned is not brahmanical territory.

The passages considered suggest that the region east of the confluence of the Ganga and the Yamunā was not considered brahmanical territory at the time of Patañjali. This does not exclude that there were Brahmins living there. Rather, it suggests that the Brahmins living in it did not receive the esteem which they deemed themselves entitled to. In Patañjali's Āryāvarta, on the other hand, we may assume that they did receive this esteem, at least to some extent.

The region east of the confluence of the Gangā and the Yamunā is of particular interest for the study of Buddhism. It is there that Buddhism arose, it is there that the Buddha lived and preached. If this region was not yet brahmanical territory at the time of Patañjali, it was certainly not brahmanical territory at the time of the Buddha, for Patañjali lived two or two and a half centuries after the death of the Buddha. The brahmanization of the eastern Ganges valley is therefore a topic of the greatest interest for the study of early Buddhism.

That this region was not brahmanical territory during the centuries separating the Buddha from Patañjali is supported by the little we know about its political history. It is here that the foundations were laid for the empire that came to cover a large part of the South Asian subcontinent. If our sources can be believed, none of the rulers involved were especially interested in the Brahmins and their ideas. ${ }^{5}$ The early kings of Magadha - Śreṇika Bimbisāra and Ajātaśatru — are claimed as their own by both Buddhists and Jainas. The Nandas, who may have consolidated imperial power at Pātaliputra around $350 \mathrm{BCE}$, appear to have been zealous patrons of the Jainas. Candragupta Maurya overthrew the Nandas, but may have had no more interest in the Brahmins than those whom he replaced. He himself is said to have adopted Jainism and died a jaina saint. His son Bindusāra is believed to have patronized non-brahmanical movements, particularly the Ājīvikas. Aśoka was interested in Buddhism; his immediate successors in Ājīvikism and Jainism. It is only with the Śungas, who supposedly

\footnotetext{
${ }^{5}$ For further details, see the final part of this introduction and chapter II.3, below.
} 
were Brahmins themselves, ${ }^{6}$ that Brahmins may have begun to occupy the place in society which they thought was rightfully theirs. This happened around 185 BCE. Forty or fifty years later, Patañjali the grammarian was still not ready to look upon the Ganges valley east of the confluence with the Jumna as being part of the land of the Āryas. Until Patañjali's date and perhaps for some time after him, our sources suggest, the region east of the confluence of the Gangā and the Yamunā was not brahmanical. I call this area Greater Magadha. Greater Magadha covers Magadha and its surrounding lands: roughly the geographical area in which the Buddha and Mahāvīra lived and taught. With regard to the Buddha, this area stretched by and large from Śrāvastī, the capital of Kosala, in the northwest to Rājagṛha, the capital of Magadha, in the southeast. This area was neither without culture nor without religion. It is in this area that most of the second urbanization of South Asia took place from around 500 BCE onward. It is also in this area that a number of religious and spiritual movements arose, most famous among them Buddhism and Jainism. All these events took place within, and were manifestations of, the culture of that part of northern India.

Vedic and early post-vedic literature contains little to inform us about the culture of its eastern neighbours. However, a passage of the Śatapatha Brāhmana speaks about the "demonic people of the east" who were in the habit of constructing sepulchral mounds that were round, unlike the four-cornered ones used by the followers of the Veda. These constructions were no doubt the ancestors of the stūpas, well-known from Buddhism. Jainism, too, had and has its stūpas, as had Ājīvikism, it seems. ${ }^{7}$ We must conclude that stūpa-like constructions were a feature of funerary practices in Greater Magadha.

Another feature of the spiritual culture of Greater Magadha is especially important, viz. its shared spiritual ideology. Knowing it is necessary if one wishes to understand the background of early Buddhism. This ideology comprised the

\footnotetext{
${ }^{6}$ For a discussion of the evidence, see Tsuchida, 2009: $14 \mathrm{f}$. Bhandare (2006: 97), on the basis of numismatic evidence, states the following: "'Śungas', if they ever existed, were probably as localized as the rest of the groups we know from coins in terms of their political prowess." McClish (2009: 326), referring to Bhandare, suggests that it was the very insignificance of the Sungas that made them resort to political Brahmanism as a way to bolster their political power.

${ }^{7}$ See further chapter III.7, below.
} 
belief in rebirth and karmic retribution. This belief was interpreted differently by different religious currents of the area. The difference of interpretation did not primarily concern the belief in rebirth and karmic retribution as such, but rather what one can do about it. Buddhism stood out in interpreting the belief itself differently (see below). All other currents that we know of shared the belief that all deeds bring about karmic retribution; those who wish to avoid karmic retribution are therefore confronted with the challenge to put an end to all activity. This can be most easily shown in the case of early Jainism.

The most characteristic trait of early Jainism is that it teaches a way of asceticism in which suppression of all activity is central, especially in its more advanced stages. Abstaining from all activity has the obvious consequence that there will be no new deeds leading to karmic retribution. What is more, the painful nature of these ascetic practices — in which practitioners remain motionless for very long stretches of time, in spite of heat, cold, exhaustion, attacks by insects and interference by meddlesome bystanders - was interpreted to bring about the destruction of the traces of earlier deeds that had not yet suffered retribution. The practitioner who is close to the goal starves to death in a state of total restraint with regard to all activity and movement. It is the culmination of a life of training and preparation.

This description, though short, gives us a clear and intelligible picture of the way to liberation in early Jainism. Activity being the source of all unhappiness, the monk tries to stop it in a most radical manner. He abstains from food and prepares for death in a position which is as motionless as possible.

Early Jainism, then, had a straightforward answer to the problem posed by the belief in rebirth and karmic retribution. Those who did not want to be reborn had to abstain from all activity, bodily as well as mental. The result would be twofold. On the one hand there would be no more deeds that would clamour for retribution; on the other, earlier deeds would be rendered ineffectual by those same ascetic practices. Together these two aspects of asceticism might lead the ascetic to the point where, at death, no more karmic retribution is required. This ascetic would then not be reborn: he would be freed from the cycle of rebirths. 
Obviously the complete immobilization practised by the early jaina ascetics only makes sense on the assumption that all deeds, both bodily and mental, were deemed to lead to karmic retribution. It was evidently not sufficient to merely abstain from certain deeds, e.g., immoral deeds. No, even the most innocent activities, right down to breathing itself, had to be stopped by those who seriously aspired for liberation.

Beside Jainism, there were other religious movements which originated in Greater Magadha, most notably Ājīivikism and Buddhism. There is however one reaction to the belief in rebirth and karmic retribution - one method as to what one can do about it - which we cannot associate with any single known movement, but which we can safely accept as being a product of the spiritual culture of Greater Magadha. It is the conviction that a certain kind of knowledge of the true nature of the self can bring about, or assist, liberation. The self, according to this teaching, is not touched by good or bad actions. The advantages in knowing such a self against the background of the belief that all deeds have karmic consequences will be obvious. The self is what one really is, different from one's body and from one's mind. This core of one's being, this self, does not act. It is easy to understand that, seen from the vantage point of this knowledge, all karmic retribution is, in the end, based on a colossal misunderstanding. Deeds are carried out by body and mind, neither of which are to be identified with the self. The self is different from both of them and carries out no activities whatsoever. Since $I$ am my self rather than my body or my mind, I cannot be affected by karmic retribution.

Knowledge of the self, seen in this way, offers extremely interesting perspectives for those who wish to escape from karmic retribution. Numerous brahmanical sources adopted this idea, which sometimes presents itself as a competitor of the path of extreme asceticism.

\section{$\underline{\text { Interactions }}$}


This knowledge of the cultural and spiritual background of Buddhism can help us to understand Buddhism as we find it in its canonical texts. ${ }^{8}$

Consider first the notion of the self. Recall that a number of religious thinkers of Greater Magadha (or influenced by ideas current in this region) postulated the existence of a self which is fundamentally inactive. The self, they maintained, does not participate in any actions whether bodily or mental. Since the self is the innermost kernel of a sentient being, it can be claimed that sentient beings, as far as their innermost kernel is concerned, do not participate in actions. Karmic retribution is therefore strictly speaking not applicable. As a result, those people who acquire knowledge of the true nature of their innermost self have made a major step toward liberation from rebirth and karmic retribution.

Buddhism arose in Greater Magadha, i.e., in the region where these ideas held sway. It seems reasonable to expect that Buddhism was influenced by this notion of the self. Was it? Does the notion of an inactive self have its place in early buddhist thought? Or at the very least, was early buddhist thought acquainted with this notion?

The answer is that early buddhist thought was acquainted with this notion, but did not accept it. This can be most clearly seen in the following passage, which is part of the second sermon which the Buddha is supposed to have delivered after his enlightenment, in Benares. Here he applies the following analysis to the five constituents of the person:

"What do you think about this, monks? Is body (rūpa) permanent or impermanent?"

"Impermanent, Lord."

"But is that which is impermanent painful or pleasurable?"

"Painful, Lord."

"But is it fit to consider that which is impermanent, painful, of a nature to change, as 'This is mine, this am I, this is my self'?"

"It is not, Lord."

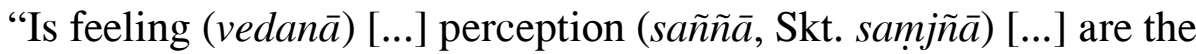
habitual tendencies (samkhāra, Skt. samskāra) [...] is consciousness (viñ̃āṇa, Skt. vijñāna) permanent or impermanent?" "Impermanent, Lord."

"But is that which is impermanent painful or pleasurable?"

\footnotetext{
${ }^{8}$ For details, see Bronkhorst, 2009, part 1.
} 
"Painful, Lord."

"But is it fit to consider that which is impermanent, painful, of a nature to change, as 'This is mine, this am I, this is my self'?"

"It is not so, Lord."

"Wherefore, monks, whatever is body, past, future, present, or internal or external, or gross or subtle, or low or excellent, whether it is far or near all body should, by means of right wisdom, be seen, as it really is, thus: This is not mine, this am I not, this is not my self.

Whatever is feeling [...] whatever is perception [...] whatever are the habitual tendencies [...] whatever is consciousness, past, future, present, or internal or external, or gross or subtle, or low or excellent, whether it is far or near - all consciousness should, by means of right wisdom, be seen, as it really is, thus: This is not mine, this am I not, this is not my self."

Underlying this passage a notion of the self manifests itself as something permanent, unchanging and pleasurable. Indeed, only that which is not impermanent, not painful, and not of a nature to change is fit to be considered as 'This is mine, this am I, this is my self'. This is a way of saying that only that which is permanent, unchanging and pleasurable might be suitably considered as 'This is mine, this am I, this is my self'. The passage does not say that it accepts the existence of such a self; it merely states that anything which is impermanent, painful, and of a nature to change cannot be the self. This rules out the five constituents of the person here enumerated. Since no other candidates are mentioned, this may imply that the existence of a self of this nature is implicitly rejected; this is not however explicitly stated.

The aim of the teaching of the Buddha is evidently not to discover the real self. In his teaching, the insight that the self does not play a part in the activities of body and mind does not help to attain liberation. On the contrary, the preoccupation with the true nature of the self has to be given up. Only then one is ready to follow the path shown by the Buddha. Seen from this practical point of view, the question as to the existence of the self is of minor importance. The main thing is that knowledge of the self plays no useful role on the Buddha's path to liberation.

The early Buddhists, then, were acquainted with the notion of a self (permanent, unchanging) which, by its very nature, cannot be touched by the activities carried out by its body and mind. This notion played, however, no role 
in the soteriological scheme of the early Buddhists. Whether or not they accepted the existence of such a self (and I would say that they probably did not), they assigned to it no soteriological function. Knowledge of such a self was not part of the buddhist way to enlightenment.

It follows that Buddhism, though acquainted with at least some of the religious notions current in its early environment, did not accept them all. Unlike other religious seekers of its age and region, Buddhism did not preach the notion of an inactive self whose knowledge supposedly leads to freedom from karmic retribution, and therefore to freedom from rebirth.

What about the other response to karmic retribution that had found followers in Greater Magadha? Remember that the Jainas were among those who had chosen an ascetic path. To prevent karmic retribution, they had opted for ascetic practices that laid emphasis on physical and mental immobilisation. The early buddhist discourses sometimes refer to Jainas, whom they call Niganththas (Skt. nirgrantha, "free from fetters"). Their methods are consistently rejected in the buddhist texts. This shows, once again, that early Buddhism did not accept all the ideas and practices that were current in its area of birth. Buddhism distantiated itself from the most prominent idea of this area (that of an inactive self) and from its most prominent practice, or rather form of asceticism (immobilisation of body and mind). Buddhism, it appears, taught a different path to liberation.

It follows that the Buddha made a distinction between his own teaching and the ascetic mode of life primarily followed by the Jainas. However, if we accept this, we are confronted with a puzzle. Elsewhere in the ancient discourses the mode of life that is here rejected is propounded by the Buddha himself, sometimes in exactly the same words. This peculiar situation provides an important key to a historical understanding of the ancient buddhist canon. This canon — and the discourses (Sūtra, Sutta) in particular — describe and recommend various practices which are presumably necessary for reaching the goal. However, not all of these were taught by the Buddha. A number of them can be identified as really belonging to other religious currents that existed in Greater Magadha and with which Buddhism was in competition. 
It is easy to understand how such non-buddhist practices could find their way into the buddhist canon. The early converts to Buddhism were drawn from Greater Magadha, some of them from religious currents such as Jainism. Already before their conversion, these people were interested in the goal of liberation from rebirth and karmic retribution. Some of them had perhaps already engaged in non-buddhist ascetic or intellectual practices to reach that goal. The Buddha taught a method to reach the same goal, or at least something that looked very similar to it. His teaching shared a number of presuppositions with those other movements, most notably the belief in rebirth and karmic retribution. It goes almost without saying that a number of those converts brought along with them some other beliefs and practices, some of which did not agree with the vision of Buddhism's founder. Some converts kept in this manner the conviction that the best way to remedy karmic retribution was to abstain from all activity. The link between means and end in this case seemed so obvious that one can hardly blame them for having preserved these forms of asceticism.

It is one thing to know that the buddhist canon contains a mixture of authentic and non-authentic buddhist practices and ideas, it is something different altogether to determine which are authentic and which are not. However, our acquaintance with the ideas and practices of other current in Greater Magadha allows us to do so: Ideas and practices that are both rejected and recommended in the buddhist canon and that correspond to the cultural and religious features of Greater Magadha should be considered borrowings into Buddhism. On the other hand, ideas and practices that are not contradicted in the ancient canon may be accepted as authentic. We thus follow the general rule that the teachings that the ancient discourses ascribe to the Buddha can indeed be ascribed to him. Only where there are reasons to doubt the authenticity of a certain teaching, for example because it contradicts other canonical statements, should we deviate from this rule.

The method here presented has the advantage of allowing for the possibility that early Buddhism introduced innovations into the realm of ideas and practices. This is an advantage, for the buddhist texts state repeatedly that the Buddha taught something new, something that had not theretofore been known in 
the world. The method does not deny that the teaching of the Buddha shared certain features with other movements from the same region. As examples we have already mentioned the belief in rebirth and karmic retribution. Only those features that it shares with those other movements but that are also rejected in the canon must be looked upon with suspicion.

It will be clear that our initial purpose to understand Buddhism in its original context leads to a methodological principle that may help us discover the original teaching of the Buddha. It goes without saying that this method must be applied with the greatest care and that its results must be considered with a healthy dose of scepticism. Too many scholars have used the obscurity that surrounds early Buddhism as an excuse to propose more or less fanciful theories. We do not need more of those. It is at the same time clear that research moves forward by way of "conjectures and refutations". This means that those who are not willing to pay attention to serious hypotheses contribute to a process which renders an interesting and legitimate field of inquiry sterile.

The question what may have been the original teaching of the Buddha has been dealt with in the first part of my book Buddhist Teaching in India (2009). ${ }^{9}$ This question will not be further pursued here. However, one misunderstanding about this teaching may here be mentioned, because it will come up once again later in this book. Whatever its details, our exploration so far suggests that the original teaching of the Buddha was in various respects radically different from other teachings that were current in its time and region. The buddhist texts themselves insist that the Buddha had discovered something new, and that he therefore taught something new. Scholars have not always believed this, but their scepticism was not justified. Some have claimed that Buddhism is a special type of Yoga. They assumed that a form of Yoga similar to Buddhism existed already at the time of the Buddha. ${ }^{10}$ They were wrong on both counts. It is true that

\footnotetext{
${ }^{9}$ In Part II of my book Absorption: Two studies of human nature (2009a) the data are subjected to further analysis and reflection.

${ }^{10}$ This opinion is first found in Senart, 1900; then in Beck, 1916: 136 f.; in Frauwallner, 1953: 173; further references in De Jong, 1997: 34-35; finally King, 1992; contra Kloppenborg, 1990. Angot (2008: 32: "plusieurs siècles avant le [Yogasūtra], du yoga était pratiqué par le Buddha, le Jina et d'autres avant ou avec eux") repeats an old mistake.
} 
classical Yoga has several points in common with Buddhism, but this is due to the influence of Buddhism on Yoga several centuries after the death of the Buddha. There are no indications that classical Yoga, or something like it, existed at his time. One of the aims of pre-classical Yoga as we find it in texts like the Mahābhārata was, like the aim of the practice of the Jainas, to suppress bodily and mental activities, ${ }^{11}$ it has little in common with the practice taught by the Buddha, and it appears that the Buddha regularly tried to make this clear - to no avail. However, we will see in a later chapter that Buddhism itself came to believe that the Buddha had practised some kind of Yoga. ${ }^{12}$

It appears, then, that already the Buddhism that we know from its earliest texts is a Buddhism that has been deeply marked by its surroundings. These early surroundings did not primarily consist of Brahmanism, but rather of the spiritual ideology of Greater Magadha, still free from brahmanical influence. Brahmanism came to play an important role in the history of Indian Buddhism, and most of the present book will deal with this. Its influence on the Buddhism which we find in the earliest buddhist texts, however, is minimal.

\section{Imperial help}

Buddhism was still young when political events took place that were to have a decisive influence on its development, and on the way it was going to interact with other religions. A brief outline of some of these political events is essential.

The region in which the Buddha preached consisted at his time of a number of competing small states. This is how the region is depicted in the early buddhist discourses, and we have no reason to doubt its veracity. One of these states was called Magadha, and this is one reason why I refer to the region as a whole as Greater Magadha. Another reason is that Magadha was to outdo the other states and to become the centre of a vast empire.

\footnotetext{
${ }^{11}$ Cf. Bronkhorst, 1993a: $45 \mathrm{f}$.

${ }^{12}$ Chapter III.5, below.
} 
The first dynasty of empire builders was that of the Nandas. Little is known about them, except that their empire at its height appears to have extended from Punjab in the west to Orissa in the east, with its capital in Pạtaliputra, in Magadha. The last of the Nandas was dethroned, in the year 320 BCE or thereabouts, by Candragupta Maurya, the founder of the Maurya empire. Candragupta was the grandfather of Aśoka, particularly well-known for having left a large number of inscriptions all over the subcontinent. It appears that the empire reached its greatest extent under him. ${ }^{13}$

As little as we know about the different rulers of the Nanda and the Maurya dynasties, one theme comes back with great regularity: most of them were well disposed toward the religions of Greater Magadha, primarily Jainism and $\bar{A}$ jīvikism. The main exception is Aśoka, who converted to Buddhism. The Nandas are remembered for their anti-brahmanical stance, and we will see that the Mauryas appear to have followed them in this, too. Perhaps this preference for the religions of Greater Magadha should not surprise us. After all, both the Nandas and the Mauryas had their capital in Pātaliputra, and therefore in Magadha, in the heart of Greater Magadha. ${ }^{14}$

In spite of their personal preferences, the rulers of the Nanda and Maurya dynasties do not appear to have made attempts to convert their subjects to their religions of choice. This can be shown most clearly in the case of Aśoka, because in his case, and only here, we have long inscriptions which inform us about the intentions of the emperor. Let us consider these inscriptions in some detail. I'll take as point of departure a chapter in a recent book by K. R. Norman, called $A$ Philological Approach to Buddhism (2006). The chapter concerned is "Buddhism and Aśoka".

In his inscriptions, Aśoka regularly emphasizes the importance of Dharma (Norman and the inscriptions have dhamma). ${ }^{15}$ This Dharma, Norman argues, cannot be identified with the Buddha-dharma. Put differently, where Aśoka

\footnotetext{
${ }^{13}$ Smith, 1958: 83 f.; Kulke \& Rothermund, 1998: 56 f.

${ }^{14}$ Pătaliputra may have been the largest city of the ancient world; Schlingloff, 1969: $29 \mathrm{f}$. See further Chakrabarti, 1997: $209 \mathrm{ff}$.

${ }^{15}$ According to Olivelle (2004: 505), "Aśoka uses the term about 111 times (excluding the repetitions found in the multiple versions of the same edi[c]t)."
} 
speaks about Dharma, he does not speak about the buddhist religion. What then is he talking about? Norman's remarks about the nature of this Dharma provide an answer (2006: 151 f.; spelling adjusted):

Aśoka's Dharma is set out clearly in several inscriptions, e.g. in a concise form in the second Minor Rock Edict: "Obey one's parents; obey one's elders; be kind to living creatures; tell the truth". All this is said to be in accordance with ancient usage (porānā pakati) [...] Elsewhere, in the third Rock Edict, a slightly expanded version of this is given: "Obedience to mother and father is good; liberality to friends, acquaintances, and relatives, to Brahmins and Śramanas is good; abstention from killing animals is good; moderation in expenditure and moderation in possessions is good" [...].

The series of seven edicts on pillars, which we call the Pillar Edicts, is devoted to an explanation of Aśoka's Dharma, with an account of how he himself has complied with it, by planting trees for shade by the roadside and digging wells and building fire-places for men and animals. Pillar Edict 1 tells of government by Dharma. Pillar Edict 2 states that Dharma consists of doing little sin, doing much good, showing compassion, making donations, telling the truth, and purity. Aśoka has done much good by not killing. Pillar Edict 3 tells of good and evil, and identified the latter as fierceness, cruelty, anger, pride, and envy. Pillar Edict 4 emphasises the need for equality of justice and the rehabilitation of prisoners. Pillar Edict 5 prohibits the killing of a number of animals which are specified by name. Pillar Edict 6 states that the aim is to bring happiness to all. All sects are to be honoured, especially by personal visits. Pillar Edict 7 seems to be a summary of all that Aśoka has done. He explains how kings in the past had sought to increase Dharma. Aśoka had decided to do it by preaching and instruction, and had instituted Dharmapillars (dhammathambhas) and Dharma-ministers (dhammamahāmātras) to put this decision into effect. The [Dharma-ministers] were concerned with all sects. Dharma is defined again as: obedience to parents, obedience to teachers, respect to the old, and proper behaviour towards Brahmins and Śramanas, to the poor, and to slaves and servants. There had been an increase of Dharma as a result of Aśoka's legislation, e.g. about killing animals, but also because of an attitude of mind, i.e. personal consciences (nighati). In this way the next world is gained.

Elsewhere, in the series of major Rock Edicts, we read that one must obey the Dharma and conform to it [...]. The gift of the Dharma is defined as the proper treatment of slaves, obedience to parents, etc., generosity to Brahmins and Śramanas, and non-killing. The Dharma gives endless merit [...].

Norman concludes that, with the exception of some few passages, it is "very clear that Aśoka's references to Dharma do not refer to the Buddha's Dharma, and 
Aśoka's Dharma was not the same as the Buddha's Dharma” (p. 153). Indeed (p. $155)$,

those who talk of him making Buddhism the state religion are very wide off the mark. In his edicts, Aśoka says little or nothing about Buddhism. There is no reference to any of the basic tenets of Buddhism, e.g. samsāra, mokkha, nibbāna, anattā, the eightfold path or the four Noble Truths. In the Separate Edicts he stated that his aim was the happiness of all [...], and a number of inscriptions include the statement that his aim was that his people may attain happiness in this world, and heaven in the other world.

Norman concludes that Aśoka's Dharma “is exclusively a moral one” (p. 153), and observes: "Except in so far as the moral ideas are quite in conformity with buddhist moral teachings, there is no hint of anything exclusively buddhist in them, and in the insistence on non-killing (ahims $\bar{a})$ his thought closely resembles the jain emphasis on this".

Aśoka's Dharma, then, is not identical with Buddhism, nor with any other specific religion for that matter. In spite of that (or should we say, because of that?), Aśoka's inscriptions betray a positively missionary spirit with regard to this Dharma. Virtually all his Rock Edicts deal with the propagation of Dharma within and beyond his empire. The $13^{\text {th }}$ Major Rock Edict, for example, states (Thapar, 1963: 256):

The Beloved of the Gods considers victory by Dharma to be the foremost victory. And moreover the Beloved of the Gods has gained this victory on all his frontiers to a distance of six hundred yojanas [i.e. about 1500 miles], where reigns the Greek king named Antiochus, and beyond the realm of that Antiochus in the lands of the four kings named Ptolemy, Antigonus, Magas, and Alexander; and in the south over the Colas and Pāndyas as far as Ceylon. Likewise here in the imperial territories among the Greeks and the Kambojas, Nābhakas and Nābhapanktis, Bhojas and Pitinikas, Andhras and Pārindas, everywhere the people follow the Beloved of the Gods' instructions in Dharma. Even where the envoys of the Beloved of the Gods have not gone, people hear of his conduct according to the Dharma, his precepts and his instruction in Dharma, and they follow Dharma and will continue to follow it.

About Aśoka's concern with different religions, Norman (2006: 159-160) states the following: 
Aśoka devotes the whole of the twelfth Rock Edict to making it clear that he is equally concerned with adherents of all religions, and he honours them all with gifts and other sorts of honours. All sects must listen to each others' Dharma [...] Then there will be an increase in each individual sect and an illumination of Dharma [...] Aśoka wishes them all to live in harmony together, without self-aggrandizement or disparagement of other sects.

\section{$[\ldots]$}

His encouragement of all sects must mean that he did not stop feeding Brahmins, and [...] his Dharma in fact specifically includes giving to Sramanas and Brahmins. His donation of caves to the Ājīvikas in his twelfth year is additional evidence that he was not devoted exclusively to Buddhism.

Let us consider somewhat more closely what effect Aśoka's measures may have had on the Brahmins. Already the first Rock Edict shows that their way of life was not made easier by these measures. Here Aśoka states: "Here no living being must be killed and sacrificed". ${ }^{16}$ The form "must be sacrificed" — prajūhitavyam, pajohitaviye, etc. - is derived from the verbal root $h u$ "to sacrifice, offer oblations", whose connection with the vedic sacrifice is well-known. The first Rock Edict, then, forbids the Brahmins to carry out sacrifices in which animals are killed. ${ }^{17}$ This edict, it may be recalled, was hewn into rock at at least nine different places scattered over the whole of Aśoka's empire. ${ }^{18}$ The prohibition to sacrifice living beings had therefore more than mere local significance.

Aśoka often mentions Brahmins in his inscriptions. They are respected, but play no role whatsoever in the administration of the empire. ${ }^{19}$ The thirteenth Rock Edict states that "there is no country where these (two) classes (nikāya), (viz.) the Brahmins and the Śramanas, do not exist, except among the Greeks

\footnotetext{
${ }^{16}$ Tr. Hultzsch, 1925: 2; cp. Bloch, 1950: 91; Schneider, 1978: 21.

${ }^{17}$ On the killing of animals, including cows, in vedic sacrifices, see Jha, 2002: $27 \mathrm{f}$.

${ }^{18}$ See Falk, 2006: 111-138.

${ }^{19}$ Lingat, 1989: 36: "nulle part [in the inscriptions of Aśoka] les brahmanes - et encore moins un purohita ou un moine bouddhiste éminent — n'apparaissent comme des forces capables d'influencer la politique royale, ou comme un contrepoids à son autoritarisme". Cp. Ruegg, 1995: 62 f,
} 
(yona)". ${ }^{20}$ This may not justify the conclusion that there were Brahmins in all parts of the empire, for the combination "Śramanas and Brahmins" or "Brahmins and Śramanas" is a fixed expression, often in the shape of a compound, which can also be used where only one of the two is meant. ${ }^{21}$ It is yet clear that all of them, including Brahmins, were forbidden to kill animals and sacrifice them. This gives rise to the suspicion that Aśoka's impartiality with regard to different religious currents was not perfect: he may have been more impartial with regard to some than with regard to others.

This suspicion may find support in the ninth Rock Edict. This inscription is positively rude about what it calls mamgala "ceremonies". It says: "Men are practising various ceremonies during illness, or at the marriage of a son or a daughter, or at the birth of a son, or when setting out on a journey; on these and other (occasions) men are practising various ceremonies. But in such (cases) women are practising many and various vulgar and useless ceremonies. Now, ceremonies should certainly be practised. But ceremonies like these bear little fruit indeed."22 Aśoka recommends dhamma-mangala "Dharma ceremonies" instead. We are at present more interested in what he rejects. A glance at the Dharmasūtras and other traditional texts will make clear that the Brahmins were masters of such kinds of ceremonies (even though the term mamgala to designate them appears to be rare in their texts). ${ }^{23}$ It seems, therefore, that Aśoka's ninth Rock Edict is criticizing certain brahmanical customs, or also brahmanical customs, without saying so explicitly.

\footnotetext{
${ }^{20}$ Tr. Hultzsch, 1925: 47, modified; cp. Bloch, 1950: 128; Schneider, 1978: 73; Parasher, 1991: 238.

${ }^{21}$ An example is the beginning of the Devadaha Sutta (MN II p. 214), which first states that certain Śramanas and Brahmins (eke samanabrāhmaña) hold a certain opinion, which is then specified as belonging to the Jainas (nigantha). See also Freiberger, 2000: 53, 56 n. 124.

${ }^{22}$ Tr. Hultzsch, 1925: 16-17; cp. Bloch, 1950: 113-114; Schneider, 1978: 52-54.

${ }^{23}$ Note that Aśvaghoșa's Buddhacarita (1.83) enumerates mangala along with japa and homa in a compound which clearly refers to brahmanical practices; see chapter III.5, below. Gautama Dharmasūtra 11.17 enumerates maìgala along with śānti and abhicāra (śānti...mañgalasamyuktāny äbhyudayikāni ... [a]bhicāra ...yuktāni ca ... kuryāt); these latter terms are sometimes associated with the Atharvan ritual (Bloomfield, 1899: 8, 25).
} 
What we learn from the above is the following. Not so very long after the death of the Buddha the north of India and much of the south became united in an empire — strictly speaking, a succession of two empires - that created almost perfect circumstances for the propagation of the religions of Greater Magadha. It seems likely that initially Jainism and Ājīivikism profited most from these exceptional circumstances, partly because both the Nandas and the early Mauryas felt favourably inclined towards these two, partly perhaps because they had more adherents at that time. Only with Aśoka did Buddhism attract the attention and allegiance of the emperor himself, which may have resulted in some specific advantages. We should not however forget that we have no reason to think that any of the Nanda and Maurya rulers discriminated against one or more of the religions of Greater Magadha. The only religion on which restrictions were imposed, at least by Aśoka, perhaps also by his predecessors and successors, may well have been Brahmanism. And yet Aśoka advocates liberality also to Brahmins.

This generosity toward the Buddhists may have resulted in certain changes within the organisation of the religion itself. We have some idea as to how, and why, this change took place. This we owe once again to an inscription of Aśoka. This emperor had a pillar erected in Lumbinī, the village where he believed the Buddha to have been born. This pillar has been found, and carries the following inscription: ${ }^{24}$

When King Priyadarśin [i.e., Aśoka], dear to the gods, was consecrated for this $20^{\text {th }}$ regnal year he came in person and paid reverence. Because the Buddha, the Śăkyamuni, was born at this place, he had a stone railing made and a stone pillar erected. Because the Lord (of the world) was born at this place, he exempted the village of Lumbini from taxes and granted it the eight shares.

Donating the revenue of a village to a worthy recipient became a regular feature in more recent centuries in India. Hundreds, probably thousands of villages have been "given away" in this manner in the course of time, and innumerable inscriptions have been found to commemorate such gifts. However, Aśoka's

\footnotetext{
${ }^{24}$ Falk, 2006: 180.
} 
inscription is unique in that it does not give a village - i.e. the revenue of that village - to a worthy donee, but to the inhabitants of the village themselves. This is puzzling. Why was the gift not granted to a buddhist monastery, or to a monastic group? These latter embodied the memory, and the teaching, of the Buddha in a much more concrete form than the inhabitants of Lumbinī, who may or may not have known what was so special about their village. I agree with Gregory Schopen (2006: 316; 2007: 61) that this strange state of affairs may mean that Aśoka did not know anything about buddhist monasteries, which indeed may not yet have existed at that time. We know that Buddhism started off as a group of mendicants, and Aśoka's inscription counts as evidence that this group was still not in a position to receive collective gifts at his time. ${ }^{25}$

It is only realistic to surmise that at least certain members of the buddhist community considered this, or similar donations elsewhere, a missed opportunity. This surmise is confirmed by the fact that the surviving authoritative texts contain rules which make the acceptance of such gifts henceforth possible. Buddhist literature reports that the merchant Anāthapiṇ̣ika (Skt. ${ }^{\circ}$ piṇḍada) put a park in Śrāvastī called Jetavana at the Buddha's disposal. ${ }^{26}$ The canonical account does not say that this park was given to the Buddha or to his community of followers, but this may be a relatively minor detail. The gift of the Venuvana by King Bimbisāra leaves no such doubts: the park is presented as a straightforward

\footnotetext{
${ }^{25}$ Compare this with Schopen, 2004: 219: "The earliest buddhist inscriptions that have survived do not refer to monasteries (vihāra). In fact, the numerous monks and nuns who made donations at $S a \bar{n} n \mathbf{c}$, for example, identify themselves not by reference to a monastery or Order, but - exactly as lay men and women donors do - by reference to their place of birth or residence. ... The wording here - exactly parallel to the wording in the records of lay donors - would appear to suggest that these nuns and monks lived in villages." Further Schopen, 2007: 61: "Even in the later inscriptions from Bharhut and Sanchi there are no references to vihāras, and they begin to appear — though still rarely - only in Kharoșthī records of a little before and a little after the Common Era, about the same time that the first indications of permanent monastic residential quarters begin to appear in the archaeological record for the Northwest, and this is not likely to be mere coincidence." Buddhist literature also preserves traces of an opposition between monks who lived in monasteries and those who lived in the wild; see Freiberger, 2006. Ray (1994: 399 ff.) suggests that buddhist monasticism arose in emulation of the rival brahmanical tradition; both shared two central preoccupations: a concern for behavioral purity and a preoccupation with the mastery of authoritative religious texts.

${ }^{26} \mathrm{Vin}$ II p. $158 \mathrm{f}$. This is the place where the Buddha, according to tradition, passed most often the rainy season; see Bareau, 1993: 21. On the significance of such traditions, see Schopen, 1997a.
} 
donation to the Buddha and his community of monks, and terminates with the Buddha's permission to his monks to accept such gifts. ${ }^{27}$ Schopen (2006: 317) draws the obvious conclusion: "If the compilers of the various Vinayas considered it 'highly important' to regulate the lives of their monks so as to give no cause for complaint to the laity, and if considerations of this sort could only have assumed high importance after buddhist groups had permanently settled down, then, since the latter almost certainly did not occur until well after Aśoka, it would be obvious that all the Vinayas that we have are late, precisely as both Wassilieff and Lévi have suggested a hundred years ago.”

The historical evidence does not allow us to determine with precision when buddhist monks and nuns settled down permanently in monasteries. ${ }^{28}$ The first epigraphic evidence for the donation of land to monastic establishments in continental India may date from the first century CE. ${ }^{29}$ In Sri Lanka land grants were presumably already given to buddhist monasteries in the latter part of the second century $\mathrm{BCE},{ }^{30}$ which may not be an unlikely date even for continental India. But whatever its exact date, when this important transition took place, Buddhism became more than ever before dependent upon rich and powerful donors. This in its turn involved it inextricably in political and social issues. We will have occasion to study the consequences of this new situation in later chapters.

Let us return to the empire of the Nandas and the Mauryas. In what other ways did it have an effect on Buddhism, and on the religions of Greater Magadha in

\footnotetext{
${ }^{27}$ Vin I p. 39; Bareau, 1963: 336-339. Bareau (1993: 32) states, with regard to the story of this meeting of the Buddha and King Bimbisāra: "Sa réalité historique est ... plus que douteuse ..."

${ }^{28}$ On monasteries for nuns, see Schopen, 2009a.

${ }^{29}$ Ray, 1989: 444. Schopen (2006a: 487 n. 1) concludes: "Since texts as we have them already know the kind of fully developed viharra that appears in the archeological record only [at the beginning of the Common Era], the texts apparently cannot be any earlier". Elsewhere Schopen (2004: 79) refers to some publications by J. Marshall and concludes: "The standardized, ordered vihāra, then, began to appear almost everywhere in the archaeological record just before and just after the beginning of the Common Era. It was then, too, that buddhist monastic communities appear to have had access to the economic resources that would have allowed them for the first time to build on a wide scale in durable materials like stone and baked brick."

${ }^{30}$ Gunawardana, 1979: 53 f.; cp. Xinru Liu, 1988: 106-07.
} 
general? We may take it for granted that the existence of this immense political entity greatly facilitated the possibilities of travel within its boundaries. The religions of Greater Magadha could therefore spread, and it appears that they did. The Jainas preserve a tradition according to which Candragupta Maurya, toward the end of his life, moved to Karnataka in the south with a large number of Jainas. This might be discarded as a late tradition, were it not for the epigraphic evidence from Tamil Nadu that has recently been made available. The earliest cave inscriptions show that there were Jainas in that region from at least the $2^{\text {nd }}$ century BCE onward. These Jainas, moreover, probably arrived from Karnataka. ${ }^{31}$

Buddhism and Brahmanism appear to have come later. ${ }^{32}$

The Jainas may have preceded the Buddhists in other regions as well, and it seems clear that the Jainas (and sometimes the $\bar{A}$ jīvikas), rather than the Brahmins, were the main competitors the Buddhists had to face. There were however some areas in which Buddhism succeeded in gaining a strong foothold already at an early date. ${ }^{33}$ Perhaps not by chance, these include regions far removed from Greater Magadha, far also from the brahmanical heartland. One of these is Sri Lanka; another one the region of Gandhāra situated in the far northwest, on the border between what are now Pakistan and Afghanistan. ${ }^{34}$

\footnotetext{
${ }^{31}$ Mahadevan, 2003: $126 \mathrm{f}$.

${ }^{32}$ According to Schalk (2002: 238-347), Buddhism arrived much later, but Gros (2009: xxvi), referring to the works of Shu Hikosaka and some other publications, has his doubts: "As far as Tamil Nadu is concerned, after the recent Japanese inventories which were eager to uncover all the, if possible ancient, traces, Peter Schalk, on the contrary, insists on demolishing all the 'pseudo' evidence for a significant buddhist presence in Tamil Nadu before the Pallava, even though some archaeological findings and the testimonies of Sri Lanka obviously give us another image." See further Champakalakshmi, 1996: 99 f.: "Institutional forces like the buddhist monastery, with their impressive monuments and cohesive guild organizations as foci of urban development are not attested to in the archaeological and epigraphic records of early Tamilakam, thus marking a major point of difference in the nature and forms of urbanism. The only notable buddhist structures (of brick) have been unearthed in the port town of Kāvērippūmpaținam, and these are dated to the fourth and fifth centuries AD, while the earlier period has no significant architectural remains." Cf. Hikosaka, 1989; Murthy \& Nagarajan, 1998.

${ }^{33}$ For an overview, see Kieffer-Pülz, 2000: 308-321.

${ }^{34}$ Fussman, 1994. According to Faccenna (1980: 32), a stūpa was built in Butkara, Gandhāra, already at the time of Candragupta Maurya, in the third century BCE; Fussman (1994: 19) is sceptical, but does not exclude that it may belong to the second century BCE. See further Falk, 2005. Āndhra in particular could be mentioned as a
} 
These two regions came to play a major role in the preservation and development of Buddhism: the former (Sri Lanka), being relatively isolated, contributed primarily to the preservation of the Buddhism it had received; the latter (Gandhāra) to developments that were to give new impulses to Buddhism in India. I will concentrate on these primarily intellectual developments in the northwest, in Gandhāra and its surroundings. Scholars sometimes speak about Greater Gandhāra, and I will follow this practice.

In order to understand the intellectual developments in Greater Gandhāra it is necessary to recall some political facts which involve a different empire. A few years before the creation of the Maurya empire political events had shaken the northwestern regions of the subcontinent. These northwestern regions had so far been part of an empire whose centre was the city of Persepoles in what we now call Iran. This was the Achaemenid empire, which extended from India in the east to Greece in the west. The downfall of this empire came from the west, and the story is well-known. King Alexander of Macedonia, better known as Alexander the Great, invaded the Achaemenid empire, killed its last emperor, and created an empire of his own that covered the earlier empire and more. In a small number of years he and his army subjected all of the former provinces of the Achaemenid empire, and created Greek settlements in various places with the purpose of keeping those regions under control. Alexander's conquest extended right into the northwestern parts of the Indian subcontinent, and included the whole of what is now Afghanistan and part of Pakistan.

Alexander's empire did not survive him for long. What did survive, was the presence of Greek colonists in places far away from their homeland. There were in this way Greeks in northwestern India who held, with varying degrees of success, political power for some two centuries following the death of Alexander. ${ }^{35}$ Their cultural influence lasted even longer, as is testified by the fact that, even after the disappearance of the last Greek kingdom on the Indian subcontinent in the middle of the second century BCE, subsequent rulers

region where Buddhism appears to have arrived well before Brahmanism; see Ramesh Chandra Babu, 2006: 10 f.; further Fogelin, 2006: 100; Arundhati, 1990: 203 ff.

${ }^{35}$ These Greeks were not confined to northwestern India and even appear for a while to have occupied Pạtaliputra, the ex-capital of the Maurya empire; see Wojtilla, 2000. 
continued the habit of printing their name in Greek characters on one side of their coins, until it finally came to an end around $400 \mathrm{CE} .^{36}$

Why are these political developments important? They tell us something about the cultural context which the Buddhists who had settled in Greater Gandhāra encountered. This region had become part of the Maurya empire around 305 BCE. However, at the time of the collapse of the Maurya empire, around $185 \mathrm{BCE}$, it had once again fallen in the hands of the Indo-Greeks. ${ }^{37}$ This means that the Buddhists of this part of the subcontinent, at that date if not already earlier, were, on an intellectual level, not confronted with Jainas and representatives of other Indian religions of their region of origin, nor were they confronted with Brahmins. Recall what Aśoka said in his thirteenth Rock Edict: "there is no country where these (two) classes, (viz.) the Brahmins and the Śramanas, do not exist, except among the Greeks". Well, these buddhist emigrants now found themselves among Greeks, and indeed ruled by Greeks, far from the Brahmins and from Śramanas different from themselves. Their intellectual and religious surroundings had completely changed, and this was going to have an effect on their own ideas. ${ }^{38}$

The surviving texts from those northwestern regions confirm that the ideas of the Buddhists who settled there did indeed change radically. ${ }^{39}$ The most striking changes concern the way buddhist doctrine was reinterpreted. Unlike earlier Buddhists, and unlike Buddhists elsewhere in or outside the subcontinent, those from the northwest used traditional elements to create something new altogether, viz., an elaborate and systematized ontology. In other words, these Buddhists used preexisting list of what were called dharmas to claim that these dharmas are all there is. What is more, they invented a thorough-going atomism, starting from the assumption that all composite objects consist of ultimate constituents. This atomism was extended to time as well: the buddhist scholiasts

\footnotetext{
${ }^{36}$ Hein, 1989: 229. This same publication proposes the term "Yavanism" to designate the forces under watered-down Greek influence that opposed Brahmanism in the third century CE.

${ }^{37}$ Falk, 2008; Salomon, 2005.

${ }^{38}$ For a more detailed discussion of the absence of Brahmanism in the northwestern parts of the subcontinent, see chapter III.7, below.

${ }^{39}$ For details, see Bronkhorst, 2009, part 2.
} 
from the northwest thought of time as a succession of ultimate, indivisible single moments.

The most remarkable aspect of this ontology is its claim that the ultimate constituents of composite objects are dharmas. Composite objects themselves are not dharmas. It follows that composite objects do not really exist. The same can be said about objects extended in time: such objects do not really exist, they are nothing but a succession of momentary objects which each have a duration of exactly one moment.

When we join up these different ideas, we end up with the claim that the only things that really exist are momentary dharmas. The familiar objects of our ordinary experience are, strictly speaking, no more than collections of successions of dharmas. This at first sight relatively simple (if surprising) way of visualising the world gains unimaginable complexity by the fact that the buddhist doctors from the northwest felt called upon to determine in great details how the different dharmas interact, what exact role each of them plays, etc. etc. We cannot deal with all of this, but a voluminous literature has survived (though mainly in Chinese translation) in which these ideas are elaborated.

There is one feature of this ontology that we cannot pass over in silence. If the objects of our ordinary experience - such as the house in which we live, the chariot we use for our journeys, the jar from which we drink water - do not really exist, why do we believe they do? The answer that is offered is the following. These objects are nothing but words. We travel in a chariot, but when we think about it we discover that a chariot is nothing but the collection of its parts, which are nothing but collections of their parts, and so on until one reaches the ultimate constituents. In reality there is only a collection of dharmas, but the word "chariot" makes us believe that there is a chariot as well.

One final question needs to be asked. Did the Buddhists of the northwestern regions invent this ontology out of nothing? Did they just make it up? The correct answer is probably both yes and no. Anything remotely resembling this ontology is completely foreign to all we know about earlier Buddhism. At the same time, the doctors from the northwest made an effort to anchor their ideas in traditional buddhist concepts. The old rejection of a self, for 
example, had become the rejection of a pudgala "person" thought of as the collection of all that makes up a human being. The conclusion was drawn that this collection does not exist because no collections exist. The lists of ultimate constituents of these Buddhists were the slightly adapted lists of important elements in the teaching of the Buddha drawn up by earlier Buddhists. The momentary nature of all that exists was deduced from declarations by the Buddha to the extent that everything is impermanent. The new philosophy of these Buddhists claimed to continue traditional buddhist teaching. In reality it did no such thing.

I have already suggested that for an explanation of this new way of thinking we have to consider the special cultural and political context in which these Buddhists found themselves. The confrontation with Greeks, with their established tradition of debate, may have been of particular importance. ${ }^{40}$ For in a debate ideas are challenged by outsiders. To hold one's ground in a debate, one has to make sure that the ideas one presents are internally coherent. The changes in buddhist thought just described all boil down to one thing: they are attempts to bring coherence into a set of received ideas, to weld them together into a coherent system of thought. ${ }^{41}$ This is what one would expect to happen in a situation where the Buddhists were challenged in debate, and this is what we see did happen.

It is perhaps no coincidence that the Milinda-pañha, a text which claims to record a discussion between the Indo-Greek king Milinda, i.e. Menander, and the buddhist monk Nāgasena, contains a passage which clarifies the rules of a scholarly debate. It reads as follows in the translation of T. W. Rhys Davids (1890: 46):

The king said: "Reverend Sir, will you discuss with me again?" "If your Majesty will discuss as a scholar (pandita), well; but if you will discuss as a king, no."

"How is it then that scholars discuss?"

\footnotetext{
${ }^{40}$ Fussman (1994: 24 f.) argues that the influence of Buddhism on the Greeks was minimal.

${ }^{41}$ Franco (2007: 76 n. 4) states: "The mere metaphysical principles of a philosophical system are like a dead body; it is the philosophical argumentation which brings it to life." It may be more precise to state that a philosophical system owes not just its life but its very existence to philosophical argumentation, i.e., debate.
} 
"When scholars talk a matter over one with another then is there a winding up, an unravelling; one or other is convinced of error, and he then acknowledges his mistake; distinctions are drawn, and contra-distinctions; and yet thereby they are not angered. Thus do scholars, O king, discuss." "And how do kings discuss?"

"When a king, your Majesty, discusses a matter, and he advances a point, if any one differ from him on that point, he is apt to fine him, saying: 'Inflict such and such a punishment upon that fellow!' Thus, your Majesty, do kings discuss."

It is not clear what historical conclusions can be drawn from this passage. It describes scholarly debates in terms that are perhaps unique in India. Contrary to the other descriptions we have from Indian sources, debates are here presented as relaxed events in which participants do not hesitate to change their opinions where necessary, more or less as in Socratic debates (with due respect for the differences). We are here far removed from the situation in which winning a debate was almost, and sometimes literally, a matter of life and death. ${ }^{42}$ When, then, Halbfass (1988: 19) states that "there is little in the [Milinda-pañha] which is Greek, aside from the name of the king”, he may have overlooked an important feature. $^{43}$

The developments sketched so far affected Buddhism independently of brahmanical influence. This was going to change. The following pages will study some of the ways in which Brahmanism did influence Buddhism. This cannot however be done without knowing something more about some crucial developments Brahmanism itself had gone through. That is therefore what we will turn to first.

\footnotetext{
${ }^{42}$ See chapter III.6, below; further Bronkhorst, 2007a; Angot, 2009: $88 \mathrm{ff}$.

${ }^{43}$ This observation is to be read with caution, for Nyāya, as argued by Nicholson (2010), has undergone a shift from agonistic to non-agonistic debate.
} 


\section{BRAHMANISM}

The political developments that had been so favourable to Buddhism had been much less favourable to Brahmanism. Aśoka's inscriptions leave no doubt that, even though he showed respect for Brahmins (or rather for Brahmins and Śramanas), he had no place for them in his imperial administration. Since his empire also covered the areas in which Brahmins had traditionally been linked to local rulers through offering ritual support, traditional sacrificial Brahmanism had lost its economic basis with the installation of the Maurya empire; presumably this had already begun under the Nandas. The Maurya empire was governed centrally, which means that governors replaced the traditional local kings, and that traditional forms of cohabitation between rulers and Brahmin priests collapsed. And if this was not yet bad enough, we have seen that Aśoka also forbade animal sacrifices. It seems fair to state that the unification of northern India under the Mauryas (and presumably already under the Nandas) was a disaster for traditional Brahmanism.

All this might have signalled its end, but it did not. Brahmanism recovered, be it in a different form. It created the means to conquer itself a new place in the world, and it ended up being extraordinarily successful. A millennium after its most desperate period, under the Mauryas, Brahmanism exerted an influence over large parts of South and Southeast Asia. Both the transformation of Brahmanism and its subsequent development have to be correctly appreciated if we wish to understand how Buddhism came to be influenced by it. A full investigation of these momentous changes are beyond the scope of this book. Only some selected aspects can be discussed in the chapters of Part II.

\section{II.1 The new Brahmanism}

Vedic Brahmanism was not the background out of which Buddhism arose. Vedic Brahmanism had its heartland in a region to the west of Greater Magadha, and did 
not provide the ideological and religious background in and against which the Buddha preached his new message. Inevitably, Buddhism and vedic Brahmanism came in contact and this contact was to have profound consequences for both. For Buddhism it meant, to put the matter in a nutshell, a long drawn-out confrontation that ended in its almost complete disappearance from the subcontinent.

The German Egyptologist Jan Assmann (2003) uses an interesting distinction between different types of religion. ${ }^{44}$ Writing in the first place about the religions of the ancient Middle East, Assmann distinguishes between primary and secondary religions. ${ }^{45}$ Primary religions are each indissociably linked to one single culture, to one single society and, most commonly, to one single language. Examples are the ancient Egyptian, Babylonian and Greco-Roman religions. Unlike primary religions, secondary religions have universal claims. They claim to be, at least in theory, applicable to all, and to be in the possession of a unique truth. Primary religions do not have such exclusive truth claims. Indeed, the ancient Middle East had no qualms about translating the names of the gods of one culture into those of another: lists of corresponding names have been found. Among the first examples of a secondary religion, Assmann counts aspects of the Jewish religion that start manifesting themselves in certain books of the Bible. With Christianity and Islam secondary religions become the norm, at least in the Western world.

This distinction between primary and secondary religions may be useful, because it encourages us to look at the early religions of India with new questions in mind. Primary religions have no exclusive truth claims. They do not therefore have the urge to convert others, and they do not send out missionaries. Secondary religions do have exclusive truth claims. They may either keep these truths to themselves; their adherents may then consider themselves the chosen people of God (this was the position adopted in Judaism). Alternatively, they may feel the urge to convert others, by whatever means they consider appropriate.

\footnotetext{
${ }^{44}$ The distinction was introduced by Theo Sundermeier, but is not identical in details with the way in which Assmann uses it; see Diesel, 2006.

${ }^{45}$ Assmann's views have given rise to an extensive and in part passionate debate; see Wagner, 2006 and the references in Wagner, 2006: 5-6 n. 12.
} 
The religions of Greater Magadha as we know them may be considered secondary religions in the sense that they have universal claims (not, be it noted, in the sense that they are derived from primary religions). These claims are not, or not primarily, truth claims of the kind we find in the monotheistic religions of the West and the Middle East. Buddhism, for example, does not maintain that the gods of other religions are false gods who ultimately do not even exist. ${ }^{46}$ Quite on the contrary, some of the gods from the vedic pantheon regularly make their appearance in the early buddhist texts, be it in roles that are adjusted to their new context. ${ }^{47}$ Other deities, "spirit-deities", some of them local, are mentioned in its texts and depicted in its art. ${ }^{48}$ No, the universal claims of the religions of Greater Magadha are not, or not primarily, truth claims. Aśoka's universal claim, as we have seen, was a moral one. He wanted to spread the Dharma - his kind of Dharma, close to the shared morality of the religions of Greater Magadha - to all people both within and without his empire. The claims of Buddhism and Jainism went further: they claimed to present the way, the only possible way, to become liberated from the cycle of rebirths. The buddhist way was different from the jaina way, to be sure. But both Buddhists and Jainas took the position that only their way was correct, the other one incorrect and useless. And the correct way did not only apply to the inhabitants of some specific regions, or to members of some specific group. No, it applied to everyone, all over the world.

Brahmanism is different. It was at first no doubt a primary religion. It was a priestly religion, not unlike the priestly religions of ancient Egypt and Mesopotamia. As such it was indissociably linked to one single culture, to one single society, and to one single language. It had a close association with the rulers of the society to which it belonged, for whom it provided ritual services. ${ }^{49}$ If Michael Witzel can be believed, the vedic priesthood primarily belonged to a single state, the Kuru state, which was also the first Indian state, formed during

\footnotetext{
${ }^{46}$ Indeed, it appears that Buddhism could live with brahmanical ancestor worship, which it subsequently absorbed in the form of transference of merit; see Herrmann-Pfandt, 1996.

${ }^{47}$ Perhaps we should say, with Ruegg (2008), that these gods were taken from a common substratum.

${ }^{48}$ DeCaroli, 2004.

${ }^{49}$ See Rau, 1957: 87 f.; Proferes, 2007.
} 
the Middle Vedic period. ${ }^{50}$ Vedic Brahmanism had no exclusive truth claims of a religious nature, and did not try to make converts. Like other primary religions, it depended for its survival on the continued existence of the society to which it belonged.

Vedic society did not continue to exist, at least not as before. We do not know when exactly the rot set in, but it is likely that the creation of the Nanda empire followed by the Maurya empire signalled the end of traditional vedic society. We have seen that there are good reasons to believe that none of the rulers of these two empires felt close to this traditional sacrificial cult. It is also important to remember that, even though these empires were not (and could hardly be) fully centralized, the power of the emperor was apparently felt in the different regions of the empire, so that earlier hierarchical structures could not normally survive as before. ${ }^{51}$ Indeed, in the inscriptions of Aśoka, "[t]he former kingdoms, which the buddhist chronicles mention and which the Mauryas had included in their Empire (Avantī, Kosala, Anga, etc.) are not named; they seem to have disappeared as political or administrative entities" (Fussman, 1987-88: 49). It is moreover clear from the language used in various inscriptions "that in the south and in the east of his Empire Aśoka used (and at times introduced) a bureaucracy of foreign origin, in greater part Magadhan, but perhaps also Gandhāran or Punjabi” (ibid., p. 59); the same might be true of the brahmanical heartland (none of the inscriptions are in Sanskrit). ${ }^{52}$ Without regular and

\footnotetext{
${ }^{50}$ Witzel, 1995; 1997.

${ }^{51}$ On the administrative structure of Aśoka's empire in particular, see Fussman, 1974; 1982; 1987-88. Fussman (1987-88: 71 f.) reaches the following general conclusion: "the Mauryan Empire functioned according to the same rules as other Indian empires of comparable size (Gupta, Mughal and British), with a central absolute power, personal, that is, dependent on the personal activity of the sovereign, relying on the army and on efficient officers; with a regional administration organized in a non-systematic fashion exercising royal authority, with more liberty the further away it was from the royal power and putting into practice the king's orders only when they fitted in with the local reality ..."

${ }^{52}$ Fussman (1987: 59 f.) reaches a different conclusion with regard to the northwest: "Aśoka allowed the survival at Kandahar and Laghman of a bureaucracy writing his acts in Aramaic, which he probably inherited from the Persian Empire, and at Kandahar of a Greek bureaucracy which he inherited from the Seleucids. So, in northwestern India none of the Mauryan rulers had interfered with local habits." (Fussman's emphasis)
} 
systematic support from the rulers, the vedic ritual tradition was threatened.

Vedic Brahmanism, if it wanted to survive at all, had to reinvent itself.

Late vedic literature suggests that Brahmins, already in the good old days, had the custom of travelling around and offering their services to kings who needed them for this or that specific ritual event. From time to time they participated in competitive encounters with other Brahmins at the royal court, and occasionally the king himself might show an understanding of the vedic sacrifice on a par with that of the Brahmins. Those good old days did not last, and we have already seen that the imperial unification of northern India by rulers from Magadha, far from the vedic heartland, probably accelerated the decline. Travelling Brahmins were henceforth likely to be faced with a diminished demand for their habitual services, especially outside the vedic heartland. What they did in response was broadening the range of services they offered. They were still willing to carry out elaborate solemn vedic sacrifices in the service of the king, but they also made a point of acquiring the skills required to counsel kings in the more practical arts of statecraft and governing; we may assume that this was no more than an extension of what they had done before. Being in essence priests, they further used their familiarity with the supernatural to predict people's future, interpret signs, pronounce curses or blessings where needed, and other such things. ${ }^{53}$ And wherever they went, and whatever they did, they always made the claim that they, the Brahmins, were entitled to the highest position in

\footnotetext{
${ }^{53}$ Brian Black, in the Conclusion of his study of the early Upanisads (2007: 171), observes: "the early Upanisads strongly criticize the sacrifice and focus on other activities as the practices which most give knowledge authority. This movement away from sacrifice at a textual level indicates that the composers and editors of the Upanisads were attempting to define their roles as Brahmins in different ways to audiences who no longer found the sacrifice favorable. In fact, not only do Brahmins define themselves as teachers and court priests rather than as ritualists, but also the ideal king is one who learns philosophy and hosts philosophical debates rather than one who is the patron of the sacrifice." Chāndogya Upanișad 7.1 contains an enumeration of brahmanical skills containing, in Olivelle's interpretation, the following items: Rgveda, Yajurveda, Sämaveda, Atharvaveda, the corpus of histories and ancient tales, ancestral rites, mathematics, soothsaying, the art of locating treasures, dialogues, monologues, the science of gods, the science of the ritual, the science of spirits, the science of government, the science of heavenly bodies, and the science of serpent beings.
} 
society, ${ }^{54}$ and disposed of great but secret powers which enabled them to impose their will in case that were to be necessary. These claims further encompassed an elaborate vision of society in which there are fundamentally four caste-classes (varna). In descending order these were the Brahmins, the Kṣatriyas (primarily kings), the Vaiśyas (merchants etc.), and at the bottom the Sūdras. ${ }^{55}$

This, then, was the situation at the time of Aśoka. I mention once more his inscription that states that there are Brahmins and Śramanas in all countries, except among the Greeks. We have already seen that this does not necessarily justify the conclusion that Brahmins had settled in, or visited more or less frequently, many or most of the provinces of Aśoka's empire, but presumably they were present in a number of them. This does not however mean that all their claims were accepted in the provinces in which they were present. Aśoka and many others with him were no doubt willing to pay respect to Brahmins, but not to give them the privileged place in society which they aspired to. Note that the inscription does not state that there are Brahmins, Kșatriyas, Vaiśyas and Śudras all over the empire. The last three of these four terms do not figure in any of Aśoka's inscriptions. We must assume that the vision of society that the Brahmins promoted was accepted neither by Aśoka, nor by the majority of his subjects. Recall further that Brahmins, unlike the Jainas, are not mentioned in the earliest inscriptions of Tamil Nadu, as pointed out in the introduction. This suggests that either there were no Brahmins in that part of the subcontinent at that time, or that they did not receive support from its rulers. ${ }^{56}$

\footnotetext{
${ }^{54}$ See e.g. MN II p. 84: "The Brahmins say thus: 'Brahmins are the highest caste-class (vanna, Skt. varna), those of any other caste-class are inferior; Brahmins are the fairest caste-class, those of any other caste-class are dark; only Brahmins are purified, not nonBrahmins; Brahmins alone are the sons of Brahmā, the offspring of Brahmā, born of his mouth, born of Brahmā, created by Brahmā, heirs of Brahmā." (tr. Ñāṇamoli \& Bodhi, 1995: 698)

${ }^{55}$ This social division was not yet all that rigorous even in late vedic days; see Rau, 1957: 62 f. Staal (2008: 59) thinks that the Puruṣa myth, which mentions these four casteclasses, is a late addition to the Rgveda.

${ }^{56}$ Champakalakshmi (1996), speaking about Tamil Nadu until 300 CE, states (p. 93): "It is significant that the impact of the varna ideology in social stratification is hardly visible in the Tamil region except in its nascent stage and in a restricted zone, viz. the eco-zone of marutam (plains / river valleys)." And again (p. 97): "Despite the presence of brähmana households there is no evidence of the impact of the varna ideology, although a late section of the Tamil grammar Tolkāppiyam, i.e. the Porul atikāram shows that
} 
Aśoka's remark if interpreted to be about the omnipresence of Brahmins in all parts of his empire except among the Greeks (a remark that, as we have seen, cannot be taken at its face value) contrasts in an interesting manner with a no doubt much younger passage that occurs in the thirteenth book - the Anuśāsanaparvan — of the Mahābhārata (13.33.19-21). This passage enumerates a number of peoples who, though originally Kṣatriyas, had become Sūdras (the word used is vrṣala), because no Brahmins were seen among them. The peoples enumerated include the Greeks (yavana), but also others: the Śakas and Kāmbojas from the northwest, further the Dravidians (dramila) from the South, the Kalingas from the East, and some others. These same peoples occur in a similar enumeration in the Mānava Dharmaśāstra (Manu 10.43-44): there too they had become Śñdras because no Brahmins were seen among them.

The Sanskrit expressions which I translate "because no Brahmins were seen [among them]" are brāhmaṇānām adarśanāt in the Mahābhārata, brāhmaṇādarśanena in the Mānava Dharmaśāstra. The editors of the Encyclopaedic Dictionary of Sanskrit on Historical Principles, which is being prepared in Pune, apparently do not feel at ease with this translation, for they propose for these passages a special meaning for adarśana "not seeing", viz. "failure to see or meet, neglect, disregard, not taking note of" (EDS vol. 2 p. 1353 no. $6 \mathrm{~B})$. In this interpretation it is their neglect of Brahmins which led to the downfall of the Greeks and others. This interpretation has no doubt been inspired by the prior conviction that there were Brahmins among all the peoples enumerated. There is however no need for a special interpretation of adarśana in these passages if we are willing to consider that, at the time when these passages were composed, there were regions of the subcontinent in which there were few or no Brahmins. This can without difficulty be accepted for the Greeks and the Śakas from among the peoples enumerated above, and for the Persians (pārada), Parthians (pahlava) and Chinese (cina) added by Manu. There is no reason to

varna norms were imposed at a later stage as a theoretical framework on what was basically a non-stratified, clan or kinship based organization with evidence of ranking only among the chiefs and ruling lineages." Palaniappan (2008) argues for an "unintended influence of Jainism on the development of caste in post-classical Tamil society". 
think differently with regard to the other identifiable peoples mentioned by Manu: the Codas and the Draviḍas from South India. ${ }^{57}$ These passages clearly suggest that the brahmanical influence in Southern India was still weak or non-existent at the time when the Anuśāsanaparvan (commonly regarded a late portion of the Mahābhārata) and the Mānava Dharmaśāstra were composed, i.e. probably during the early centuries of the Common Era.

What occupations did Brahmins aspire to in regions where their vision of society and their pre-eminence as a group was not recognized? We have very little evidence pertaining to the role which Brahmins played in regions that were not brahmanized. Perhaps our most important source of information is the early buddhist canon, which often mentions them. However, this source is to be used with great care, for the buddhist canon was not composed in one day. Oskar von Hinüber describes its formation in the following words (1995: 187):

There is no doubt that the Buddha formulated his teaching in oral instruction to his immediate pupils. The extent of this corpus of original Buddhist texts is as unknown as is its actual shape during the days of the Buddha. These texts were learnt by heart, transmitted, and to an unknown, but probably fairly large extent shaped and reshaped by those who handed them down, and they went thus through a considerable transformation before they reached the stage of Pāli and became codified as the canon of the Theravāda school written down for the first time during the reign of Vattagāman̄i Abhaya (89-77 B.C.), or that of true Buddhist Sanskrit as used by the Mahāsāṃghikalokottaravāda school, Gāndhārī or even Paiśācī and other languages now lost.

The practical conclusion we can draw from this state of affairs is that we know that portions, perhaps major portions, were added to the buddhist canon, others changed or edited, but that it is virtually impossible to find out what happened to each separate pericope.

\footnotetext{
${ }^{57}$ An inscription in the southernmost village of India, Kanyākumāri, claims that the founder of the Cola dynasty, finding no Brahmins on the banks of the Kāverī, brought a large number of them from Āryāvarta and settled them there. His remote descendant Vīra-Rājendra created several brahmadeya villages and furnished forty thousand Brahmins with gifts of land. See Gopinath Rao, 1926.
} 
In spite of these complications, the ancient canon is relatively homogeneous in the information it provides about the position of Brahmins and their vision of society. To begin with the latter: the brahmanical vision of society is rarely referred to in the ancient discourses. Society is here not normally divided into the four brahmanical varnas, viz. Brahmins, Kṣatriyas, Vaiśyas and Śūdras. The bulk of society is described as consisting of "house-holders" (Pāli gahapati), without internal distinctions. ${ }^{58}$ This category should not be separated from that of the Brahmins, at least not in principle, because Brahmins, too, can be householders, and are then sometimes referred to as brähmana-gahapati. ${ }^{59}$ The occupation most frequently associated with the gahapati is that of merchant or guild leader (Pāli sețthi), but the PTS Pali-English Dictionary, which makes this observation, adds that a gahapati can also be a kassaka "farmer" or a dārukammika "carpenter", ${ }^{60}$ There is no reason to assimilate the gahapati (Skt. grhapati) to the Vaiśya, as some modern interpreters are inclined to do. ${ }^{61}$ Indeed, "the buddhist scheme of khattiya, brähmana, and gahapati, is never classified as either vaṇna or as jāti". ${ }^{62}$ The Vaiśya is part of the brahmanical vision of society, which the gahapati is not. This is not to deny that these house-holders are often presented, already in the Pāli canon, as "men of substance", but this may be due to the propagandistic tendency of the texts to depict the Buddha as being in interaction with important people rather than with the proletariat. Note further that the same "householder" figures frequently in inscriptions dating from the centuries just before and after the beginning of the Common Era. ${ }^{63}$

There are relatively few exceptions to this in the buddhist canon. The discourses that are aware of the brahmanical varnas (Pāli vaṇna) deal "most often

\footnotetext{
${ }^{58}$ Wagle, 1966: 69; Chakravarti, 1987: 66 f.; 2006: $101 \mathrm{f}$.

${ }^{59}$ Chakravarti, 1987: $72 \mathrm{f}$. This compound does not always need to mean "Brahmins who are house-holders", and may also be used to mean "Brahmins and householders"; see Widmer, 2008: 437 n. 29. Note however that sometimes brāhmanagahapatika ("Brahmins who are house-holders" or "Brahmins and householders") are subsequently addressed as gahapatis, which shows that, independently of the interpretation of the compound, Brahmins are here considered house-holders; so e.g. MN I p. 285-86; 290-91; III p. 291.

${ }^{60}$ PTSD p. 248.

${ }^{61}$ Fick, 1897: 164; Nattier, 2003: 24.

${ }^{62}$ Chakravarti, 1987: 100.

${ }^{63}$ Chakraborti, 1974: $14 \mathrm{f}$.
} 
with situations in which the Buddha converses with a Brahmin"64 and argue against them. An example is the Assalayyana Sutta. Here the Buddha points out to the Brahmin Assalāyana that among the Greeks the four varnas do not exist, that there are there only two varnas, viz., masters (ayya, Skt. ärya) and slaves (dāsa), and that masters become slaves and slaves masters. However, "the term vaṇna ... appears only in the context of abstract divisions of society into various social categories. We have no evidence of it being used in any concrete situation. ... It seems to have remained a theoretical concept without any parallel in actual practice. $" 65$

The example of the Assalayana Sutta is of particular interest, because it is possible to make a reasonable estimate as to its date. The reference to the Greeks shows that this account was composed after the invasion of Alexander, after the time when Greeks had settled in the borderlands of the Indian subcontinent. Perhaps we can go one step further. Remember that Aśoka had stated in one of his inscriptions that there were Brahmins and Śramanas in all countries (of his empire) except among the Greeks. Aśoka had not said a word about the omnipresence of the brahmanical varṇas in his empire, and indeed, he never uses the expressions Kṣatriya, Vaiśya and Śūdra. It seems more than plausible that the Assalayana Sutta (or at any rate this part of it) is not only more recent than the invasion of Alexander, but also more recent, perhaps much more recent, than the inscription of Aśoka. ${ }^{66}$

Also other buddhist discourses that deal with the brahmanical vision of society, or with the claimed superiority of Brahmins, contain indications suggesting that they were composed at a late date. This is not the occasion to enter into a detailed analysis. ${ }^{67}$ Instead I propose to look at two specific Brahmins who are presented in the texts as occupying two different but characteristic positions in society.

\footnotetext{
${ }^{64}$ Chakravarti, 1987: 98; cf. Mertens, 2005: 239 f.

${ }^{65}$ Chakravarti, 1987: 104.

${ }^{66}$ Attempts to date the Assalāyana Sutta before Alexander (e.g., Halbfass, 1995) must therefore be considered with suspicion.

${ }^{67}$ For more details, see Bronkhorst, 2007: $353 \mathrm{f}$.
} 
The first one is Asita, the "buddhist Simeon". Asita, it may be recalled, is the old Brahmin who sees the new-born Gautama and predicts, on the basis of his physiognomy, that this baby will either become a world-ruler or a Buddha. Similar predictions had been made at the cradle of earlier Buddhas, and of the present Buddha, again normally by Brahmins. ${ }^{68}$ There is little reason to believe that the story represents historical reality. The very notion of a world-ruler suggests that it was invented after Aśoka, or in any case after the unification of northern India into an empire by the Nandas; at the time of the historical Buddha there was no world-ruler, and there had never been one in India. But whatever its exact date, the episode of Asita shows that predicting the future was, or became, a typically brahmanical occupation.

The second Brahmin to be considered is Varșākāra (Pāli Vassakāra), whom the texts present as the minister of a king, King Ajātaśatru. This Brahmin has a discussion with the Buddha toward the end of the latter's life, asking him for political advice. ${ }^{69}$ There are various reasons to think that this meeting between the Buddha and Varșākāra never took place, and that the story is a later invention. ${ }^{70}$ This does not change the fact that we find here the notion of a Brahmin who has made himself the minister of a king who is not otherwise known for being partial to the Brahmins. We are of course reminded of Cānakya, supposedly the minister of Candragupta Maurya. In this latter case, there are reasons to think that the story was invented in the light of an increasingly influential brahmanical ideology (chapter II.3, below). It seems possible that Varșākāra owed his (invented) existence to the brahmanization that Buddhism underwent in subsequent centuries (chapter III.5, below).

\footnotetext{
${ }^{68}$ Bronkhorst, 2007: 272 f.; Bareau, 1962: $13 \mathrm{f}$.

${ }^{69}$ For a presentation and analysis of this advice, see Bechert, 1966: $6 \mathrm{f}$.

${ }^{70}$ Bareau, 1970: 67 f.; Schmithausen, 1996: 67; 1999: 50. The story also contains the prediction by the Buddha of the future greatness of Pattaliputra; Schlingloff (1969: 42) comments: "In unserem Falle scheint weniger eine historische Überlieferung den Anstoss zu der Legendenbildung gegeben zu haben, als vielmehr die Tendenz, die erstaunliche Grösse dieser Stadt mit einer Prophezeiung des Religionsstifters in Verbindung zu bringen, und darüberhinaus ihren Namen zu erklären: aus Pāṭali-Dorf (-grāma) wurde Pātali-Stadt (-putra). Gerade dies aber erschüttert die Glaubwürdigkeit der Legende, denn das zweite Glied des Stadtnamens putra ('Sohn') kann niemals die Bedeutung 'Stadt' annehmen."
} 
Varșākāra is described as being the minister of King Ajātaśatru, not as his Purohita. The Purohita "royal chaplain" is yet an important figure in the brahmanical vision of the world. ${ }^{71}$ The Purohita conducts the ceremonial rites of the king, and is his close adviser. The word is known to the buddhist canon, but not frequent in it. An analysis of its occurrences in the Pāli Suttas provides some interesting data.

In the Digha Nikāya the word occurs in this function ${ }^{72}$ only in three discourses: the Kütadanta Sutta, the Mahāpadāna Sutta, and the Mahāgovinda Sutta. ${ }^{73}$ In the first and the last of these, the Purohita concerned is the Buddha himself during an earlier existence, who uses his privileged access to the king to inspire the latter to do good works: in the Kütadanta Sutta to perform a sacrifice in which no living beings are slain, in the Mahägovinda Sutta to renounce the world. The Mahāpadāna Sutta is about earlier Buddhas, most specifically the Buddha called Vipassin. Vipassin was a prince, son of a king who had a Purohita. This Purohita plays no role whatsoever in the story, is however the father of a son who is among Vipassin's first converts.

The Majjhima Nikāya uses the word Purohita in one single passage, which is however repeated in three different discourses: the Kandaraka Sutta, the Apaṇnaka Sutta, and the Ghotamukha Sutta $;{ }^{74}$ it is repeated a fourth time in the Ariguttara Nikāya. ${ }^{75}$ In this passage the Buddha distinguishes four kinds of persons: (i) the person who torments himself, (ii) the person who torments others, (iii) the person who torments himself and others, and (iv) the person who torments neither himself nor others. The Buddha then explains that the third kind of person, clearly the worst because he torments both himself and others, is he who performs brahmanical sacrifices along with his Purohita. The Purohita is here the co-perpetrator of disreputable activities.

None of these Suttas describe, or even pretend to describe, the situation at the time and in the region of the Buddha. They do not suggest, much less state,

\footnotetext{
${ }^{71}$ See, e.g., Spellman, 1964: 72 f.; Willis, 2009: $169 \mathrm{ff}$.

${ }^{72}$ DN II pp. 272 and 275 have the word in the expression kayam brahma-purohitam, apparently without any semantic connection with our royal chaplain.

${ }^{73}$ There is a brief reference to this at AN III p. 373.

${ }^{74}$ MN I p. 343 f.; 412; II p. $161 \mathrm{f}$.

${ }^{75}$ AN II p. $207 \mathrm{f}$.
} 
that the kings whom the Buddha met during his peregrinations in Greater Magadha had Purohitas at their court. All of them, with the exception of the Mahāpadāna Sutta, which is totally uninformative in this matter, criticize the way of life the Purohita stands for, either by involving him directly in activities that are to be rejected, or more subtly by suggesting that the only good Purohita is a buddhist Purohita (to adapt a well-known expression). Either way these discourses can be understood as reactions to a brahmanical challenge which made itself felt during the centuries following the demise of the Buddha.

We have already seen that some of the canonical texts that deal with brahmanical ideas and practices appear to be relatively late additions. Perhaps all of them are. Quite independent of this question is the observation that the buddhist canon often mentions Brahmins, even sometimes Brahmins who are engaged in typically brahmanical activities. However, these Brahmins are presented as living in a world which remains fundamentally non-brahmanical.

Our reflections so far allow us to gain some insight into the way in which Brahmins coped with the changed political circumstances that had arrived with the creation of empire in northern India. Some of them moved beyond the areas where they might hope to be engaged as priests into regions that did not accept their vision of society. In those other regions they offered services adjusted to the new environment. They could not expect there to be asked to carry out major vedic sacrifices, and indeed, certain brahmanical texts admit that the times have changed: sacrifice is here stated to be the dharma of the Dvāpara-yuga, now past, while giving (dāna) is the dharma of the present Kali-yuga. ${ }^{76}$ Brahmins could however perform simpler magical rites for those who needed them, and use their supernatural skills in the service of interpreting signs, predicting the future and other similar things. They also made a point of emphasizing their special aptitude at giving counsel to rulers, at the same time giving up all claims to the royal office. ${ }^{77}$ It seems likely that Brahmins had been royal counsellors in the good old

\footnotetext{
${ }^{76}$ Koskikallio, 1994: 254.

${ }^{77}$ Dumont, 1970: 66, citing W. W. Hunter.
} 
days, apart from being ritual advisors and executioners. ${ }^{78}$ In the new situation, where the kingly interest in their rites had diminished, they still insisted on their practical skills in matters politic. The legend of Cānakya or Kauṭilya illustrates this. We will see below (chapter II.3) that this legend does not report historical truth, as far as we can tell. But lack of historical reliability does not make the legend any the less interesting.

Recall that Cānakya / Kauṭilya supposedly was a Brahmin and the minister of Candragupta, the founder of the Maurya empire. His political skills were such that there was little for Candragupta to do but follow his advice and find himself as a result in the possession of an empire. The Maurya empire, in short, was created by a Brahmin minister for his king. The propagandistic value of this legend is obvious: future rulers who heard it were reminded of the importance of finding a suitable brahmanical counsellor.

Brahmins did more than creating legends. They took their responsibility of giving practical counsel to rulers very seriously. They created a whole literature of a kind that one might designate "advice for kings". They described in great details how kings should behave. One way of doing so was presenting the example of earlier righteous kings. Scholars agree that this was one of the motives behind the composition of the great Sanskrit epics, the Mahābhärata and the Rāmāyaṇa. The famous Bhagavadgìtā, which is part of the Mahābhārata, plays a key role in the brahmanical legitimation of war, ${ }^{79}$ but other portions of the epic, among them the Udyogaparvan, carry a similar message. ${ }^{80}$ There were also treatises containing more direct advice. The most important surviving text of this genre is the Arthaśāstra, whose author has been called, in a recent publication, "the first great political realist". ${ }^{81}$ It was, incorrectly but not surprisingly, attributed to the minister of Candragupta — Cānakya or Kautilya —, mentioned above. Another famous text reserves considerable space for a discussion of correct governance: this is the famous Mānava Dharmaśāstra, better known as Manusmrti or the Laws of Manu. In brief, Brahmins made gigantic efforts to

\footnotetext{
${ }^{78}$ Gonda, 1955.

${ }^{79}$ Stietencron, 1995: $167 \mathrm{f}$.

${ }^{80}$ See, e.g., Malinar, 2007: $35 \mathrm{ff}$.

${ }^{81}$ Boesche, 2002.
} 
justify their positions at or around the royal courts. A complete list of further brahmanical works on politics would include the Tantrākhyāyika or Pañcatantra, long sections of Purāṇas, Kāmandaki's Nītisāra, and much else. ${ }^{82}$

The Arthaśāstra and the Mānava Dharmaśāstra deal, as their names indicate, with artha (wealth) and dharma (virtue) respectively. These were two of the three ends of life, the so-called trivarga, which brahmanical texts promote as legitimate pursuits, the third being kāma (pleasure). Kings were expected, almost required, to pursue these three. The Greeks and their not brahmanically oriented successors in northwestern India were occasionally blamed for not caring about these. $^{83}$

The primary task of the new Brahmanism was to impose its vision of society. Imposing its vision of society meant speaking about society as hierarchically ordered into Brahmins, Kșatriyas, Vaiśyas and Śūdras. Our earliest nonbrahmanical sources do no such thing. The Aśokan inscriptions do not use this terminology, even though they acknowledge the presence of Brahmins. The early buddhist canon does not do so either, with the exception of some passages that normally discuss the brahmanical claims.

Of particular interest are some passages in the buddhist canon which state that Ksatriyas are the best of men, as are, to a lesser extent, those passages that use the expression Kṣatriya at all. Both testify to the fact that the authors of these passages knew the brahmanical division of society. They did not accept this division, to be sure, but they had begun to use some of its terminology. They even used that terminology to state that the Kṣatriyas rather than the Brahmins are the best of men. Clearly, buddhist authors have here started to use the terminology of their opponents, with the very purpose of rejecting their opponents' position. These passages are all the more curious because, to cite the words of Ashok Aklujkar (2003), "it would have been blatantly inconsistent for the Buddha and

\footnotetext{
${ }^{82}$ Scharfe, 1989: $22 \mathrm{f}$.

${ }^{83}$ Pargiter, 1962: 56 (as cited in Hein, 1989: 234 n. 21): bhavisyantīha yavana dharmatah kāmato 'rthatah̆/ naiva mūrdhābhișiktās te bhavișanti narādhipāh// yugadoșadurācārā bhaviṣyanti nrpās tu te/ strīnạ̣̄ bālavadhenaiva hatvā caiva parasparam/l ... vihīnās tu bhavisyanti dharmatah kāmato 'rthatah.
} 
Jina to deny supremacy based on birth to the Brahmins and then to assert the same in the case of the Kṣatriyas”.

These passages may contain an indication as to the direction future developments would take. Adopting the brahmanical vision of society was not, or not always, the result of a sudden decision, a sudden change of mind. The process was much more subtle, much less visible to the unprepared. The first step in the transition was the adoption, or partial adoption, of brahmanical terminology. Adopting a terminology is not the same as adopting an ideology, but it prepares the ground. Imperceptibly the discussion shifts from a total rejection of the fourfold division of society to questions as to which of the four is highest. By the time such questions were raised, the acceptance of the fourfold division as a whole was probably well on its way. ${ }^{84} \mathrm{We}$ will return to this in a later chapter (III.5).

It appears that other brahmanical notions sneaked in in a similarly surreptitious manner. Remember that Brahmins did not try to convert anyone in the usual sense of the term. All they did was remind their interlocutors of some for them elementary facts. The hierarchical division of society was one of them, the role of Brahmins as the natural counsellors to kings another, the natural place of Sanskrit — the only true and correct language — in matters relating to the state a third. Rulers were invited to accept these supposed facts, but accepting them did not imply that support should be denied to other groups. If rulers wanted to get the best out of the Brahmins in their kingdom, they might donate settlements (agrahāras) to some of them: the Brahmin inhabitants of those agrahäras would be able to spend their time performing rites for the benefit of the king and his kingdom. ${ }^{85}$ But once again, the king was not required to convert in anything like its usual sense. Indeed, he did not have to accept the whole package of services that the Brahmins had on offer. Donations to Brahmins might therefore come from a king who was also generous to others, including Buddhists. The fact that

\footnotetext{
${ }^{84}$ The Mahāvastu (Mvu II p. 139) provides an example where it mentions the four varnas for no other reason than to explain the colours of four vultures which the Tathāgata had seen in a dream before his enlightenment. The idea appears to be that liberation is open to all of them.

${ }^{85}$ For a study of the agrahāra, see chapter II.4, below.
} 
King Khāravela of Kalinga in the first century BCE was a Jaina, for example, did not prevent him from providing Brahmins with agrahāras, or at any rate tax exemptions. Indeed, it did not prevent him from carrying out a vedic Rājasūya sacrifice. ${ }^{86}$

An inscription from the middle of the second century CE may be the first from which we can conclude that the brahmanical vision of society had gained the upper hand in the region concerned. It is the famous inscription of the Kṣatrapa king Rudradāman in Girnār (Gujarat), famous because it is the first political inscription of any importance in Sanskrit. This in itself suggests a brahmanical presence, but there is more. This inscription is among the first to mention the varnas "caste-classes" that play a central role in the brahmanical ideas about society, and to refer to a Vaiśya. ${ }^{87}$

People have expressed surprise about the use of Sanskrit by a ruler who is not known to have performed vedic sacrifices. Other rulers, who did perform vedic sacrifices, had not used Sanskrit, but Middle Indic. The confusion resolves itself once we remind ourselves that Brahmanism is not a religion to which one has to convert. Brahmins offered a variety of services to kings, who could choose what suited them. Some might have a vedic rite performed for their well-being without caring too much about other claims of the Brahmins. Others might not care about vedic rites, yet adopt the vision of society that Brahmins offered. Rudradāman appears to belong to this latter category. He was not the last. ${ }^{88}$

\footnotetext{
${ }^{86}$ Jayaswal \& Banerji, 1933. For Khāravela's date, see note 210, below.

${ }^{87}$ Note that not even the inscriptions of the Guptas contain any allusion to the hierarchy of the varnas; Fussman, 2007: 705.

${ }^{88}$ For a more detailed discussion of Rudradāman's inscription, see chapter II.2, below.
} 


\section{II.2 The spread of Sanskrit}

The spread and development of Brahmanism makes its presence primarily felt in the historical record through the extensive use of its sacred language, Sanskrit. This widespread presence of Sanskrit has misled some scholars into thinking that the phenomenon of which it is a manifestation is of a linguistic nature, and should somehow be explained in terms of the Sanskrit language itself. This is not correct. This chapter will present a discussion and analysis of the increased use of Sanskrit in virtually the whole of South Asia and important parts of Southeast Asia. It will show that Brahmanism itself rather than its sacred language is the determining factor behind these developments.

A recent publication - Nicholas Ostler's Empires of the Word (2005) - presents itself in its subtitle as A Language History of the World. Understandably, it deals extensively with what it calls "world languages", languages that play or have played important roles in world history. An introductory chapter addresses, already in its title, the question "what it takes to be a world language". The title also provides a provisional answer, viz. "you never can tell”, but the discussion goes beyond mere despair. It opposes the "pernicious belief" which finds expression in a quote from J. R. Firth, a leading British linguist of the midtwentieth century (p. 20): "World powers make world languages [...] Men who have strong feelings directed towards the world and its affairs have done most. What the humble prophets of linguistic unity would have done without Hebrew, Arabic, Latin, Sanskrit and English, it is difficult to imagine. Statesmen, soldiers, sailors, and missionaries, men of action, men of strong feelings have made world languages. They are built on blood, money, sinews, and suffering in the pursuit of power." Ostler is of the opinion that this belief does not stand up to criticism: "As soon as the careers of languages are seriously studied - even the 'Hebrew, Arabic, Latin, Sanskrit and English' that Firth explicitly mentions as examples it becomes clear that this self-indulgently tough-minded view is no guide at all to what really makes a language capable of spreading." He continues on the following page (p. 21): "Evidently, total conquest, military and even spiritual, is 
not always enough to effect a language change. [...] [C]onsider Sanskrit, taken up all over South-East Asia in the first millennium AD as the language of elite discourse, even though it came across the sea from India backed by not a single soldier."

What then, according to Ostler, made Sanskrit a world language? Still in the same introductory chapter, he makes the following observation (p. 21): "In that muscular quote, Firth had emphasised the religious dimension of power, and this is often important: perhaps, indeed, we should be talking not of language prestige but language charisma. Sanskrit, besides being the sacred language of Hinduism, has owed much to disciples of the Buddha [...]" But for more detailed information we must turn to the chapter dedicated to the career of Sanskrit (pp. 174-226). The spread of Sanskrit across South and Southeast Asia is here presented in the following words (pp. 176-178):

A dialect of Indo-Iranian, [Sanskrit] is first heard of in the North-West Frontier area of Swat and the northern Punjab (now in Pakistan), spoken by peoples who have evidently come from farther north or west [...] Somehow their descendants, and even more their language, spread down over the vast Indo-Gangetic plain, as well as up into the southern reaches of the Himālaya ('snow-abode') mountains, so that by the beginning of the fifth century $\mathrm{BC}$ the language was spoken in an area extending as far east as Bihar, and as far south, perhaps, as the Narmada. [...]

The result was the present-day situation, a northern Indian heartland, stretching from sea to sea, of languages more or less closely related to Sanskrit. [...] It also gained one offshoot in Śrī Lankā to the far south, creating the Simhala [...] community there: according to tradition, this group had come from Gujarat, on the north-western coast, in the fifth century BC. The advance of Aryan is continuing to this day in the northern regions of Assam and Nepal, where the official languages (Assamese, and Nepali or Gurkhali) are both Aryan, but have not yet become the vernaculars of large majorities of their populations.

Not all the spread of Sanskrit was through full take-up of the language as a vernacular. Even when pre-existing languages, such as Telugu, Kannada and Tamil, held their own, they were usually permeated with terminology from Sanskrit. [...]

The process of Sanskritisation did not stop at the boundaries of the subcontinent. Over the course of the first millennium AD, Indian seafaring traders or missionaries made landfall, not only in Śri Lanka, but also in many places along the coasts of South-East Asia. Here, the language spread above all as a language of elite civilisation and religion (whether Hindu or Buddhist), but the influence, and evidently the study made of 
Sanskrit as a vehicle of high culture, was profound. The region is known as Indo-China, quite rightly, for it became a crucible for the competing influences of India and China.

This passage can easily give rise to confusion, for it speaks simultaneously of two altogether different phenomena: the spread of Sanskrit and the spread of the (other) Indo-Aryan languages. Sanskrit is an Indo-Aryan language, to be sure. The spread of the Indo-Aryan languages other than Sanskrit, however, is to be distinguished from the spread of Sanskrit. Both spread over large parts of the South Asian subcontinent, but the spread of the Indo-Aryan languages different from Sanskrit was not the result of the spread of Sanskrit, contrary to what the above passage suggests. We will see below that the two phenomena were largely independent of each other, and were of a different nature.

Ostler also speaks of a spread of Sanskrit northward, round the Himalayas to Tibet, China, Korea and Japan (p. 178). We will not deal with this spread, because it is debatable whether it was one at all. We have no reason to think that Sanskrit established itself in any of these countries. There are no Sanskrit inscriptions, nor do we have any reason to believe that any Sanskrit texts were composed there. We only know that these countries were interested in Buddhism, and to a lesser extent in Indian culture, so that efforts were made to translate texts from Sanskrit into regional languages. As a result there were some scholars in those countries who knew Sanskrit, but this is not to be confused with a supposed spread of Sanskrit, just as little as the Christianization of Europe is an indication of the spread of Hebrew.

With regard to the Southeast Asian region, Ostler compares the widespread embrace of Indian culture with the enthusiasm for Americana that captured the whole world in the second half of the twentieth century (p. 179): "In that advance too the primary motives were the growth of profits through trade, and a sense that the globally connected and laissez-faire culture that came with the foreigners was going to raise the standard of life of all who adopted it. As with the ancient advance of Indianisation, there has been little or no use of the military to reinforce the advance of Microsoft, Michael Jackson or Mickey Mouse. There has been little sense that the advance is planned or coordinated by 
political powers in the centre of innovation, whether in India then, or in the USA today. And the linguistic effects are similar too: English, like Sanskrit, has advanced as a lingua franca for trade, international business and cultural promotion."

Here, then, Ostler gives his opinion about the role of Sanskrit in Southeast Asia, and the reason of its success. It was, he thinks, a lingua franca for trade, international business and cultural promotion. Unfortunately he does not tell us why he thinks so, and we will see that there are good reasons to reject this opinion as not corresponding to historical reality.

As a whole, the picture presented by Ostler is seriously misleading. Contrary to what he suggests, the spread of Sanskrit in northern India did not precede the spread of other Indo-Aryan languages; the opposite is true in many parts. This is not so because Sanskrit developed out of those other Indo-Aryan languages; it did not. The spread of Sanskrit is rather to be looked upon as an altogether different phenomenon. Indeed, the spread of Sanskrit into the southern regions of the subcontinent and into Southeast Asia was not accompanied by any preceding or subsequent spread of other Indo-Aryan languages.

The epigraphical evidence illustrates the above. The earliest inscriptions in Indo-Aryan languages do not use Sanskrit. For some four centuries, from the time of Emperor Aśoka (3rd cent. BCE) onward, they used only Indo-Aryan languages other than Sanskrit. Sanskrit does not make its appearance in inscriptions until the early centuries of the Common Era. Then it gradually takes over and becomes the inscriptional language par excellence in the whole of the South Asian subcontinent and much of Southeast Asia. For almost a thousand years Sanskrit "rules" in this enormous domain. Sheldon Pollock (1996; 2006) speaks for this reason of the "Sanskrit cosmopolis", which he dates approximately between 300 and $1300 \mathrm{CE}$.

How do we explain the strange vicissitudes of the Sanskrit language? Is Ostler right in thinking that it owes its remarkable spread to being a lingua franca for trade, international business and cultural promotion? Does this make sense at all, once we realize that the spread of Sanskrit is to be distinguished from the 
spread of vernacular languages? And is the spread of Sanskrit into Southeast Asia to be explained in the same manner as its spread within the Indian subcontinent?

Pollock puts the emphasis elsewhere. By introducing the expression "Sanskrit cosmopolis", he draws attention to the political dimension of the phenomenon. One defining feature of the Sanskrit cosmopolis, he states (1996: 197), "is that Sanskrit became the premiere instrument of political expression in the polities that comprised it, those of most of South and much of Southeast Asia." He rightly points out that Sanskrit was not a lingua franca of the kind proposed by Ostler: "'Sanskrit's spread was effected by traditional intellectuals and religious professionals, often following in the train of scattered groups of traders and adventurers, and carrying with them disparate and decidedly uncanonized texts of a wide variety of competing religious orders, Śaiva, Buddhist, Vaiṣnava, and others. [...] There is little to suggest [...] that Sanskrit was an everyday medium of communication in South let alone Southeast Asia, or that [it] ever functioned as a language-of-trade, a bridge-, link-, or koiné language or lingua franca (except among those traditional intellectuals) [...]”. Pollock continues: "We have little direct evidence that Sanskrit actually functioned as a language of practical imperium - the medium of chancellery communication or revenue accounting, for example — certainly not in Southeast Asia, almost certainly not in peninsular India or the Deccan [...]". The hypothesis he then proposes (pp. 198-99) is "that Sanskrit articulated politics not as material power — the power embodied in languages-of-state for purposes of boundary regulation or taxation, for example, for which so-called vernacular idioms typically remained the vehicle — but politics as aesthetic power. To some degree the Sanskrit 'cosmopolis' I [i.e., Pollock, JB] shall describe consists precisely in this common aesthetics of political culture, a kind of poetry of politics. ${ }^{, 90}$ Further explanation follows on p. 199: "Constituted by no imperial power or church but in large part by a communicative system and its political aesthetic, the Sanskrit ecumene is characterized by a transregionally shared set of assumptions about the basics of power, or at least about the ways in which power is reproduced at the

\footnotetext{
${ }^{89}$ Pollock, 1996: 198.

${ }^{90}$ Similarly Pollock, 2006: 14. Note that Geertz (1980: 123), too, speaks of "a poetics of power".
} 
level of representation in language, and Sanskrit's unique suitability for this task." Having discussed the epigraphical and related evidence from a number of regions, Pollock then depicts the situation around $1000 \mathrm{CE}$ in the following passage (pp. 229-30):

A traveller around the year 1000 [...] would have seen, from the plain of Kedu in central Java to the basin of Tonlé Sap in Cambodia, from Gangaikondacolapuram in Tamil Nadu to Patan in Gujarat and beyond, imperial formations that had many features in common. The material and social ones I have ignored here: their largely hierarchized societies, administered by a corps of functionaries, scribes, tax collectors, living in grand agrarian cities geometrically planned in orientation to the cardinal points and set within imaginary geographies that with their local mountains, rivers, and springs recapitulated the geography of India, urban structures "freighted with cosmic symbolism, helping one to visualize the order of things" [...] It is their common political-cultural, especially literary-cultural, features I have emphasized: the existence of cultural and political élites assiduously mastering the intricate codes and protocols of Sanskrit poetry, and the publication of their works throughout these cities, in varying degrees of density and grandeur — stately public poems in Sanskrit engraved on the ubiquitous copper-plates recording gifts and donations, or on stone pillars looming up from gigantic architectural wonders.

There was thus, I think, a certain concrete reality to the 'Sanskrit cosmopolis', one that does not exist only in the retrospective gaze of the historian. For a millennium, and across half the world, élites participated in a peculiar supralocal ecumene. This was a form of shared life very different from that produced by common subjecthood or fealty to a central power, even by shared religious liturgy or credo. It was instead a symbolic network created in the first instance by the presence of a similar kind of discourse in a similar language deploying a similar idiom and style to make similar kinds of claims about the nature and aesthetics of polity about kingly virtue and learning; the dharma of rule; the universality of dominion. A network, accordingly, wherein the élite shared "a broadly based communality of outlook", and could perceive "ubiquitous signs of its beliefs".

Readers may be surprised to see that this passage makes no reference to Brahmins. Isn't there an old and well-established link between Sanskrit and Brahmins? Can one speak about the spread of Sanskrit without speaking about Brahmins that presumably introduced and cultivated it? Pollock speaks very little 
of Brahmins in his article. ${ }^{91}$ Where he does so, his aim appears to be to weaken or even to deny the link between the two. He does so, for example, where he criticizes the notion of 'legitimation'. He cites (p. 236) in this connection the following passage from an article by Hermann Kulke (1990: 20 ff.):

At a certain stage of this development Brahmins 'came hither' [to mainland Southeast Asia] in order to legitimize the new status and wealth of these chiefs. Obviously there existed a tremendous need of additional legitimation which obviously no other traditional institution was able to provide fully [...] Brahmins appear to have been invited particularly as a sort of 'extra' legitimators of a new and more advanced type of authority which was not sanctioned by the traditional societies of South-East Asia [...] Obviously in both [South India and Southeast Asia] there had existed the same or at least similar socio-political needs for a new type of legitimation." ${ }^{, 92}$

Pollock is very critical about the notion of 'legitimation', and he argues that "there is no reason to accept legitimation theory". ${ }^{93}$ However, he seems to think that the rejection of "legitimation theory" also does away with the question of the connection between Brahmins and Sanskrit in South India and Southeast Asia, for he does not return to it. And yet, there is ample evidence to show that there were Brahmins in virtually all the regions that were affected by the spread of Sanskrit.

\footnotetext{
${ }^{91}$ This in spite of the fact that he observes in another article that "to choose a language for literature [...] is at the same time to choose a community" (Pollock, 1998: 9).

${ }^{92}$ See, however, Kulke, 1986: 274: "legitimation was not the only attraction of Hinduism for tribal leaders. As pointed out by Wolters, Hinduism must have been particularly attractive for 'men of prowess' because of its highly developed system of magical power derived from meditation (tapas)." Nemec (2007: 210), reviewing Pollock's The

Language of the Gods in the World of Men (2006), expresses some reservations about the rejection of legitimation.

${ }^{93}$ Elsewhere Pollock calls it a "functionalist explanation [which] is not only anachronistic, but really is a mere assumption, and an intellectually mechanical, culturally homogenizing, and theoretically naive assumption at that" (1998: 13; cp. 2006: 18). And again: "It is typical [...] to reduce one of these terms (culture) to the other (power) - a reduction often embodied in the use of the concept of legitimation of power. There is no reason to assume that legitimation is applicable throughout all human history, yet it remains the dominant analytic in explaining the work of culture in studies of early South and Southeast Asia." See further Pollock, 2006: $511 \mathrm{ff}$. The general theory of ritual I have presented elsewhere (2010; forthcoming a) and which argues that ritual anchors situations and events occurring in "ordinary" reality into a "higher" reality yet opens the door to the notion that ritualists can give a deeper and presumably more permanent character to interhuman relationships that may have been created with the help of brute force, thus "legitimating", among others, power relationships.
} 
Even if one were to accept that legitimation theory does not explain their presence in all those regions, this hardly justifies leaving this presence out of consideration. Innumerable Sanskrit inscriptions, both in India and in Southeast Asia, testify to the presence of Brahmins. It is a fair question to ask whether the users of Sanskrit in all these regions were not preponderantly Brahmins. Even if one were to admit that 'legitimation' was not the reason why these Brahmins were there, there is no reason to deny that they were there, and that their presence was intimately connected with the use of Sanskrit in those regions.

Elsewhere in his article Pollock suggests that there was no specific link between Sanskrit and Brahmanism during the period he considers. He does so while discussing the first appearances of Sanskrit in inscriptions in South Asia. In short, his argument is that ruling dynasties with a clear penchant for brahmanical religion did not necessarily use Sanskrit in their inscriptions, and that the first Sanskrit inscriptions we have were commissioned by rulers who had no special links with Brahmanism. The Sātavāhanas — whose rule lasted from the last quarter of the third century BCE to about the middle of the third century CE constitute the most important example of the former. As Pollock puts it (p. 202): "From the multitude of inscriptional and numismatic evidence available to us now [...], something very striking emerges: Although this was a decidedly vaidika dynasty, as evidenced both by their continual performance of śrauta rites and by explicit self-identification (e.g., ekabamhana [...]), there is no evidence for their use of Sanskrit in any non-liturgical context [...]".94

The first political inscription in Sanskrit of importance is the celebrated inscription of the Kṣatrapa king Rudradāman, which dates from shortly after 150

\footnotetext{
${ }^{94}$ Similarly Pollock, 2006: 61 f.; in this publication Pollock further draws attention (p. 62 f.) to the early inscriptions in Prakrit of the Pallavas. The expression ekabamhanasa occurs in the Nāsik Cave Inscription no. 2 (Senart, 1906: 60 1. 7). It allows of various interpretations: if bamhana represents Sanskrit brāhmaṇa, it means "the unique Brāhmaṇa" (Senart) or "of him who alone (was worthy of the name of) a Brāhmaṇa" (Bühler); if bamhana represents brahmanya, it means "the only supporter of Brāhmaṇas" (R. G. Bhandarkar). In the former case one might have to conclude that the Sătavāhanas were themselves Brahmins, in the latter that they supported Brahmins. See on all this Bhandarkar, 1938: 32-33. The mention of a rājarisi, Skt. rājarși "Royal Sage", in this same inscription convinces Bhandarkar (p. 33) that the Sātavāhanas were not Brahmins themselves.
} 
$\mathrm{CE}$ and sets a new trend. ${ }^{95}$ Pollock comments in the following manner (p. 20506): "The appropriation of Sanskrit for public political purposes at the end of the first century $\mathrm{CE}$, is an event symptomatic or causative of a radical transformation of the historical sociology of Sanskrit, comparable, and no doubt related, to the buddhist appropriation of Sanskrit [...] In this process newly settled immigrants from the northwest seem to participate centrally. [...] What is historically important is not so much that newcomers from Iran and central Asia should begin to participate in the prestige economy of Sanskrit [...] but rather that Sakas, Kuśānas [sic] and the Buddhist poets and intellectuals they patronized begin to turn Sanskrit into an instrument of polity and the mastery of Sanskrit into a source of personal charisma." This development should not, according to Pollock, be interpreted as essentially linked to traditional Brahmanism (p. 207): "W6 "We may [...] wish to rethink the received account that imagines a 'resurgence of Brahmanism' leading to a 're-assertion of Sanskrit' as the language of literature and administration after the Maurya period [...], and consider instead the possibility that a new cultural formation, a Sanskrit cosmopolitan formation, was on the point of being invented." Indeed, “[t]he radical reinvention of Sanskrit culture seems to have occurred - at least, it is here that we can actually watch it occurring $-[\ldots]$ in a social world where the presuppositions and conventions of vaidika culture were weakest: among newly immigrant peoples from the far northwest of the subcontinent (and ultimately from Iran and Central Asia), most importantly the Śakas (the so-called Indo-Scythians), especially a branch of the Śakas known as the Western Kṣatrapas, and the Kuṣāṇas” (2006: 67).

By disconnecting Sanskrit from Brahmanism and from Brahmins, Pollock can then formulate questions relating to the spread of Sanskrit in terms of the language itself rather than in terms of its users. This allows him to propose his hypothesis of "politics as aesthetic power". A consequence of this disconnection is that "we cannot simply read off automatically from the choice to express political will in Sanskrit any particular social consequences (e.g., hierarchization, hegemony; the production of false belief)" (p. 245). No, the qualities of the

\footnotetext{
${ }^{95}$ There are some earlier Sanskrit inscriptions, mostly brahmanical in affiliation. For details, see Salomon, 1998: 86 ff.; Pollock, 2006: 60 f.; Witzel, 2006: 479 f.

${ }^{96}$ Similarly Pollock, 1998: 10; 2006: 74.
} 
language itself have to account — if not fully, then at least to a large extent — for its extraordinary expansion: "This had to be a language of transethnic attraction; a language capable of making translocal claims [...]; one powerful not so much because of its numinous qualities [...], but because of its aesthetic qualities, its ability somehow to make reality more real. [...] These aesthetic qualities, moreover, are authenticated by the language's possessing a tradition of literary texts that embody and realize them." (p. 239-40). Indeed, "the unique expressive capabilities of Sanskrit poetry allow the poet to make statements about political power that could be made in no other way" (Pollock, 2006: 139). ${ }^{97}$

All this is interesting and deserves careful consideration. It yet leaves one with the apprehension that the traditional connection between Sanskrit and Brahmins has been too hastily disposed of. Pollock is no doubt right in rejecting "the received account that imagines a 'resurgence of Brahmanism' leading to a 're-assertion of Sanskrit' as the language of literature and administration after the Maurya period". Indeed, one of the main points of the preceding chapter is that Brahmanism did not resurge after the Maurya period, but commenced at that time its spread over the subcontinent and beyond for the first time. We are, as a matter of fact, confronted with two remarkable instantiations of spread: the spread of Brahmanism and the spread of Sanskrit. And the question that cannot be avoided is: Were these two really unconnected? Is it not more likely that they had something to do with each other?

In order to answer these questions we must be clear what we are talking about. Pollock's observations about the spread of Sanskrit are enlightening and, by and large, sufficient for our present purpose. But what is meant by "spread of Brahmanism"? The expression Brahmanism can be used to designate the religion and culture of the Veda, but it is only in a very limited sense that these can be said to have spread during the period following the Mauryas. No, the spread of Brahmanism was primarily the spread of Brahmins as Brahmins. That is to say, a region is brahmanized when its population, or its rulers, accept Brahmins as the by right most eminent members of society. This population, or these rulers, are not so much converted to a different religion: no converts are made to vedic

\footnotetext{
${ }^{97}$ See further Pollock, 2006: $254 \mathrm{f}$.
} 
religion, or to any other specific religion promulgated by the Brahmins. No, these populations or rulers are made to accept a different vision of society, in which Brahmins are highest because they have access to the supernatural. An important instrument in the hands of the Brahmins is their knowledge of the Veda, a collection of texts which the vast majority of the population is not even allowed to hear recited, much less study. ${ }^{98}$ It is their often secret knowledge that gives them the power to work for the good of a kingdom, its ruler and its population. It also allows them to do the contrary, and this is an important reason to humour them.

For reasons that are in need of further investigation, Brahmins succeeded in the course of time to convince many rulers that it was a good thing to provide them with what they needed to carry out their rites and do whatever else would benefit the kingdom. The growing presence of Brahmins all over South Asia is well documented, but they also came to be present in Southeast Asia, even in countries that became buddhist: "even in states where Hinayana Buddhism prevailed, Brahmans played an important ceremonial part, especially at Court, and still do so in Burma, Siam and Cambodia, though themselves strikingly different from their counterparts in India." 99

The oldest known inscriptions in Indonesia - we read in The Economic and Administrative History of Early Indonesia (van Naerssen \& de Iongh, 1977:

\footnotetext{
${ }^{98}$ Udbhatasiddhasvāmin's Viśeșastava contrasts the vedic and the buddhist attitudes with regard to their sacred texts as follows: "Die vedischen Worte der Irrlehrer trägt man nur heimlich vor; du [i.e. the Buddha] (aber) hast brüllend mit der Stimme eines Löwen den Dharma dargelegt" (v. 23); "Die, die den Dharma wünschen, sagen, dass man den Śūdras kein Wissen vermitteln solle; du (aber) hast aus Mitleid auch den Canḍālas den Guten Dharma dargelegt" (v. 59) (tr. Schneider, 1993: 59, 69).

${ }^{99}$ Hall, 1968: 12; Skilling, 2007. About Champa, Mabbett (1986: 294) observes: "Except for a short while around the end of the ninth and the beginning of the tenth centuries, Buddhism in Champa never really rivalled Hinduism. Epigraphic statistics give some idea of the relative importance of the two faiths, at least in royal and courtly circles: of 130 inscriptions published, 21 are not sectarian, 92 refer to worship of Śiva, 3 are directed to Viṣnu, 5 to Brahmā, 7 to Buddhism, and 2 to Śiva and Viṣnu jointly." (These numbers correspond to those given in Mus, 1934: 369.) For the fate of Sanskrit after the introduction of Theravāda Buddhism in Burma, see Bechert \& Braun, 1981: xxxviii f.: this language continued to be used for some time for the secular sciences, i.e., grammar, lexicography, metrics, poetics, medicine, pharmacology, astrology, gemmology, logic. Interestingly, in Burma a work dealing with the right conduct of a king (the Rājanititi) was composed in Pāli by court Brahmins (Bechert \& Braun, 1981: 1xi). However, "it seems that all Rājanīti verses are direct translations from Sanskrit" (Bechert \& Braun, 1981: 1xxvii). See further Skilling's (2009: 36) remarks on the Lokaneyyapakarana.
} 
18) - are those of East Borneo. Here there are seven stone sacrificial posts, called yūpas by archaeologists, that date from around $400 \mathrm{CE}$. What is written on them is described in the following terms: ${ }^{100}$

In clear, well written Sanskrit verses Mūlavarman 'the lord of kings', his father - Aśvavarman, 'the founder of a noble race' — and his grandfather, 'the great Kundungga, the lord of men' — are mentioned on the occasion of a sacrifice. 'For that sacrifice', we read on one of the stone poles, 'this sacrificial post has been prepared by the chief amongst the twice-born [dvija, JB]'. ('Twice-borns' is applied to the members of the brahmanical or priestly caste.) Apparently these "priests [vipra, JB] who had come hither" (as is written on the second pole) were rewarded by king Mūlavarman for their religious services. Thus the third inscription sounds: "Let the foremost amongst the priests and whatsoever other pious men hear of the meritorious deed of Mūlavarman, the king of illustrious and resplendent fame - (let him hear) of his great gift, his gift of cattle, of a wonder-tree [...], his gift of land. For this multitude of pious deeds this sacrificial post has been set up by the priests."

A Sanskrit rock inscription in West Java dating from about $450 \mathrm{CE}$ deals with an occasion on which the Brahmins were presented with 1000 cows. ${ }^{101}$

About Cambodia we read the following: ${ }^{102}$

In Cambodia the Brahmans for many centuries maintained a powerful hierarchy. They were the only one of the four castes that was really organized, this caste having taken form in the fifth century and been constantly augmented by immigrants from India. ${ }^{103}$ In the days when

\footnotetext{
${ }^{100}$ van Naerssen \& de Iongh, 1977: 18. Cf. Vogel, 1918.

101 van Naerssen \& de Iongh, 1977: 23.

${ }^{102}$ Quaritch Wales, 1931: 58-60.

${ }^{103}$ Even though the system of four varnas does not seem to have taken root in Southeast Asia, this may not be due to lack of trying. In Cambodia, according to Chatterji (1928: 239), Sūryavarman I is stated to have "established the division of castes", and Harșavarman III boasts of having made the people observe strictly the duties of the four castes. Chatterji adds, however (p. 240): "We do not get much substantial evidence of the other [i.e., different from Brahmins] castes however." See further Mabbett, 1977 (p. 439: "varnas [in Angkor] were largely ceremonial orders"); Sanderson, 2004 (p. 394: "The superficiality of the concept of caste among the Khmers is also evident in the fact that varnah, the Indian Sanskrit term for the [four] caste-classes from Brahmin to Sūdra, was put to other use in Cambodian Sanskrit and Old Khmer. There it denotes title-groups or corporations associated with various kinds of royal service. A person could be honoured by enrolment into such a Varna, and new Varnas could be created by royal decree."). A text which seems to have been issued in the fourteenth century CE by King Krtanagara of East-Java prescribes: "The Śivaite's son shall be a Śivaite, the Buddhist's son a Buddhist,
} 
Yaśovarman was king (acceded A.D. 889), Śaivism was predominant, and we learn from the following inscription that the Brahmans still enjoyed a position similar to that which was theirs in India:

"This king, well-versed (in kingly duties), performed the Kotihoma and the Yajñas (vedic sacrifices), for which he gave the priests magnificent presents of jewels, gold, etc."104

The cult of the Royal God, though founded by Jayavarman II (A.D. 802), did not reach the height of its development until some two centuries afterwards, and was especially associated with Vaiṣnavism and the temple of Ankor Vat. This cult led to the Brahmans enjoying an even more exalted position. The Cambodian hierarchy was established by Jayavarman II, and the priesthood became hereditary in the family of Śivakaivalya, who enjoyed immense power; indeed, this sacerdotal dynasty almost threw the royal dynasty into the shade. ${ }^{105}$ Brahmans were depicted on the reliefs of Ankkor Vat and Coedès has identified Drona and Viśvāmitra amongst them. ${ }^{106}$ In one of the reliefs which illustrates a royal procession, it is interesting to note that the Brahmans are the only onlookers who do not prostrate themselves before the king, as was also the case in India. [...] Another point of interest that we learn from the reliefs of Ankor Vat and Ankor Thom is that not only the Brahmans, but also the aristocracy wore the chignon, the lower classes having short hair.

One very remarkable sign of the power of the Brahmans during the Ankor period is that, contrary to the modern custom, by which princesses of the royal blood rarely marry, formerly alliances were common with the Brahmans; ${ }^{107}$ and up to the present day there is a tradition amongst the Bakus, who are the descendants of the ancient Brahmans, that in the event of the royal family failing, a successor would be chosen from amongst them.

As early as the reign of Jayavarman V (A.D. 968) we find evidence of the admixture of Mahāyāna Buddhism with the cult of the Royal God.

"The purohita should be versed in Buddhist learning and rites. He should bathe on the days of the festivals the image of the Buddha

the rāja's son a rāja, the manuh's (common layman's) son a manuh, the śūdra's son a sūura, and so on all classes shall follow their own avocations and ceremonies." (Ensink, 1978: 188)

${ }^{104}$ Reference to Chatterji, 1928: 114.

${ }^{105}$ Reference to Chatterji, 1928: $80 \mathrm{f}$.

${ }^{106}$ Reference to Coedès, 1911: plates xii and xiii.

${ }^{107}$ Cp. Coedès, 1964: 219: "Jayavarman V [Cambodia, 10th century] maria sa soeur Indralakshmī au brahmane hindou Divākarabhața, né dans l'Inde sur les bords de la Yamunā, auteur de diverses fondations çivaïtes"; p. 223: "Les familles brahmaniques s'alliaient souvent avec la famille royale: les mariages entre brahmanes et kshatriyas semblent avoir été fréquents, ces deux castes constituant, au-dessus de la masse, une classe à part, représentant l'élément intellectuel et la culture hindoue, sans qu'il faille en conclure que, du point de vue racial, cette aristocratie ait été très différente du reste de la population". 
and should recite Buddhist prayers."

And the rites and duties of the purohitas remained a mixture of Hinduism and Mahāyānism until the introduction of Pāli Buddhism in the thirteenth century, ${ }^{109}$ after which this powerful sacerdotal caste degenerated with their religion to the position occupied by the modern Bakus. But the Brahmans of Cambodia perhaps never sank so low as did those of Campā, where "In the Po Nagar Inscription (No. 30) we read that the king's feet were worshipped, even by Brāhmaṇas and priests".

King Yaśovarman of Cambodia created numerous āśramas, among them some that were specifically meant for Vaiṣnavas, Śaivas and Buddhists. Interestingly, in all three, including the buddhist âśrama, Brahmins had to be honoured more than anyone else: "In the Saugatāśrama, too, the learned Brāhmaṇa should be honoured a little more than the āchārya versed in Buddhist doctrine [...]". ${ }^{110}$

It would be a mistake to think of the Brahmins in Southeast Asia as an endogamous group of people, as they were in India. Indeed, G. Coedès (1964: 54) cites a Chinese text from the 5th century which states that "dans le royaume de Touen-siun il y a plus de mille brahmanes de l'Inde. Les gens de Touen-siun pratiquent leur doctrine et leur donnent leurs filles en mariage; aussi beaucoup de ces brahmanes ne s'en vont-ils pas". ${ }^{111}$

de Casparis \& Mabbett (1992: 287) sum up present knowledge about the role of Brahmins in Southeast Asia:

Brahmins had great influence in the Southeast Asian courts in various capacities. As they had access to the sacred texts, the lawbooks and other literature in Sanskrit, they were employed as priests, teachers, ministers and counsellors: the principal advisers of the kings. Government,

\footnotetext{
${ }^{108}$ Reference to Chatterji, 1928: 163. Pāsādika (2006: 468), referring to an unpublished lecture by Peter Skilling, provides the following information about the second SamborPrei Kük inscription in Chenla: "A Sanskrit inscription [...] from the reign of Áśānavarman I, records the erection of a linga in Śaka $549=$ CE 627, by the high official Vidyāviśeșa, a Pāśupata brahman, who was versed in grammar (śabda), the brahmanical systems of Vaiśeșika, Nyāya, and Sāṃkhya, and the doctrine of the Sugata."

${ }^{109}$ An inscription from Arakan, which Johnston (1944: 365) dates to the beginning of the ninth century, speaks of a king named Ānandacandra, who was a Mahāyāna Buddhist and an upassaka. This did not prevent him from having four monasteries (mața) built for fifty Brahmins, "provided with lands and servants, furnished with musical instruments and musicians" (pp. 381-82).

${ }^{110}$ Goyal, 2006: 221.

${ }^{111}$ Coedès explains in a note (1964: 54 n. 6): "Le Touen-siun était une dépendance du Fou-nan, probablement sur la Péninsule Malaise".
} 
particularly in early centuries, depended upon such men, who were the chief available sources of literacy and administrative talent and experience. As in the early Indian kingdoms, an important office was that of the purohita, a chief priest with ritual and governmental functions. The epigraphic record of the mainland kingdoms demonstrates the powerful influence of purohitas, notably in Burma and Cambodia, where they often served under several successive rulers and provided continuity to the government in troubled times. In ninth-century Angkor, for example, Indravarman I had the services of Śivasoma, who was a relative of the earlier king Jayavarman II and was said to have studied in India under the celebrated Vedānta teacher Śañkara.

About the origins of these Brahmins - were they Indians or not? - de Casparis and Mabbett have the following to say: ${ }^{112}$

If such Brahmins were Indians (the Indian Brahmins are indeed occasionally mentioned in Southeast Asian inscriptions), one wonders how or why they should have left India. This is the more surprising since Indian lawbooks contain prohibitions for Brahmins against overseas travel, which was regarded as ritually polluting. These prohibitions may have had little practical effect, and would not have deterred ambitious men lured by the hope of honour and fortune in a distant land. It has been suggested that some learned Brahmins were invited by Southeast Asian rulers at a time when commercial relations between Indian and Southeast Asian ports had spread the fame of such Brahmins to the courts. It is indeed likely that this happened sometimes, but probably not on a large scale. It is, for example, striking that the Indian gotra names, never omitted in Indian inscriptions, are not normally mentioned in Southeast Asia. On the other hand, in the few cases where they are mentioned it is likely that they refer to Indian Brahmins. It therefore follows that the great majority of Southeast Asian Brahmins would have been Southeast Asians, many of whom had acquired their knowledge of the Sanskrit texts and of brahmanic ritual in Indian ashrams.

The services of the Southeast Asian Brahmins extended beyond the limits of any single religion: ${ }^{113}$

Not only in the 'Hindu' courts, such as Angkor, but also in the Buddhist courts, such as those of Pagan in Burma and Sukothai in Thailand, the brahmins conducted the great ceremonies, such as the royal consecration, and functioned as ministers and counsellors, but had to share their

\footnotetext{
112 de Casparis \& Mabbett, 1992: 287.

${ }^{113}$ de Casparis \& Mabbett, 1992: 288. Cp. Golzio, 2003: 79 f.
} 
influence with that of the Buddhist monks. By its very nature Buddhism was concerned with the acquisition of spiritual merit and moral perfection rather than with the rites and ceremonies of a royal court, which were left to the brahmins. The grand ceremonies in Pagan [...] required the services of numerous brahmins, although Theravāda was then well established. In Cambodia, as late as the thirteenth century [...], Jayavarman VIII built a temple for the scholar-priest Jayamangalārtha, and likewise for the brahmin Vidyeśavid, who became court sacrificial priest. The Chinese visitor Chou Ta-kuan refers to the presence of brahmins wearing the traditional sacred thread.

de Casparis and Mabbett (1992: 288) draw the following conclusion:

What is shown by the role of such brahmins is that it is appropriate to speak of Brahmanism as distinct from the specific cults of Siva or Viṣnu, or any of their innumerable kin: the priests stood for a social order and for the rituals that gave to the political or local community a sense of its unity and its place in the world.

The part of this conclusion which must be emphasized is that Brahmanism is distinct from the specific cults of Śiva or Viṣnu, or any of their innumerable kin, and that the Brahmins stood for a social order. ${ }^{114}$ This seems obvious and undeniable, and yet it is often overlooked by scholars who wish to assign Brahmanism to the category 'religion'. In reality, Brahmanism represents primarily a social order. Only this way can we make sense of the evidence from Southeast Asia, ${ }^{115}$ as well as of the evidence from South Asia. ${ }^{116}$

It appears, then, that some of the proposals made already in 1934 (in

\footnotetext{
${ }^{114}$ Pāsādika (2006: 465), referring to Bhattacharya (1997), mentions the "synthesis of Śaivism and gruesome local cult or possibly 'the' indigenous religion of Cambodia". "Originally this cult culminated in human sacrifices to the mountain-spirit performed by the king himself. [...] The early Cambodian kings could have had no objection to the assimilation of a primitive and gruesome cult by Brahmanism thanks to which [...] the mountain-spirit [...] became Bhadreśvara, i.e. Śiva [...]"

${ }^{115}$ A modern example is the following (Ensink, 1978: 188): "in Bali today we see the Buddha priest and the Siva priest (padanda Buddha, - Siva) officiating in one and the same religion, the Āgama Tīrtha, 'religion of holy water', or Āgama Hindu Bali. Both belong to the highest class, the brahmans. Outwardly they are distinguished - among other things - by the way they wear their hair, the Sivaite tying it in a knot on the crown of his head, the Buddhist combing his locks backwards and down to the neck. Each has his rules (brata) [:] the padanda Buddha is allowed to eat everything, while the diet of the padanda Śiva is subject to many restrictions."

${ }^{116}$ See chapter III.6, below.
} 
Dutch) by J. C. van Leur still hold good. ${ }^{117}$ About South Asia he said (van Leur, 1955: 97$):^{118}$

The chief disseminator of the process of 'Indianization' was the Brahman priesthood; the aim of the 'Brahman mission' was not the preaching of any revealed doctrine of salvation, but the ritualistic and bureaucratic subjugation and organization of the newly entered regions. Wherever the process of 'Indianization' took place, 'religious' organization was accompanied by social organization - division in castes, legitimation of the ruling groups, assurance of the supremacy of the Brahmins. The colossal magical, ritualistic power of the Brahman priesthood was the most characteristic feature of early Indian history. The rationalistic, bureaucratic schooling of the priesthood as the intellectual group, which went to make up its great worth, its indispensability even, for any comprehensive governmental organization, was [...] interwoven with the sacerdotal function. The Brahman priesthood developed high qualities in that field as well, but its decisive influence came from the magical, ritualistic power of domestication it in the absoluteness of its power was able to develop.

The spread of brahmanical institutions to Southeast Asia was hardly more than a continuation of this process (pp. 103-04):

The Indian priesthood was called eastward - certainly because of its wide renown - for the magical, sacral legitimation of dynastic interests and the domestication of subjects, and probably for the organization of the ruler's territory into a state.

Pollock may object to the word legitimation in these two passages. Nothing much is lost by removing it. ${ }^{119}$ The factual situation remains the same. Brahmins were called to Southeast Asia (or were found in Southeast Asia; there is no reason to insist on the Indian origin of all of them), and these Brahmins brought with them their sacred language, Sanskrit. ${ }^{120}$

It will be interesting to draw also Sri Lanka into the discussion. This country was buddhist for most of its history, and it had to be governed and needed

\footnotetext{
${ }^{117}$ Cp. Kulke, 1986a: $256 \mathrm{f}$.

${ }^{118}$ On the 'Indianization' of Southeast Asia, see further Mabbett, 1977a.

${ }^{119}$ Or one might replace it with protection: "protection of the ruling groups" and "sacral protection of dynastic interests" may give less reason for objections.

${ }^{120}$ They also brought with them the information about the consecration of temples that we find in Indian texts such as the Käsyapaśilpa, information which was also used in the building of buddhist structures; see Ślaczka, 2006, esp. chapters 7.3 and 7.4.
} 
organization. Where did the Singhalese rulers find information about these matters? Lingat (1989: 152) has the following to say about this: ${ }^{121}$

Où les rois de Ceylan vont-ils chercher des conseils sur l'organisation administrative du royaume, sur le choix et les attributions des ministres, sur la police des villes et des villages, sur les impôts, leur taux, leur perception, sur l'organisation de la justice et comment elle doit être rendue, et sur les questions multiples que pose sur le plan interne le gouvernement d'un Etat? Ce n'est certes pas dans les Ecritures, que ces problèmes ne concernent pas, mais dans une littérature indépendante. [...] il semble qu'il n'y ait eu à Ceylan aucun ouvrage consacré à la politique; du moins aucun traité de littérature pâlie n'en mentionne. [...] Il est dès lors naturel que les rois de Ceylan se soient tournés vers la littérature sanskrite qui est fort riche en ouvrages de ce genre. Outre l'Arthaśāstra de Kautilya qui paraît bien être mentionné dans les chroniques sous le nom de Koțalla (LXIV, 3; LXX, 56) mais surtout comme traité militaire, une référence semble nettement être faite au Code de Manu sous le nom de Manunītivisārada (LXXXIV, 1). Mais, le plus souvent, il est seulement fait allusion à l'art de la politique, nīti, ou rājanīti, l'art de la politique à l'usage des rois. On trouve aussi Manunīti (LXXX, 9: Vijayabāhu II), l'art de la politique selon Manu, expression dans laquelle le mot Manu, croyons-nous, ne vise pas nécessairement l'auteur mythique du Mānavadharmaśāstra mais plutôt le prototype du législateur humain. Manunīti, comme rājanīti, désigne l'ensemble des règles et des principes suivant lesquels la société humaine, entendez la société laïque, doit être organisée, administrée, pour fonctionner convenablement. Le Bouddha n'a touché à ce sujet qu'incidemment [...] Mais ce sont les ouvrages brahmaniques qui contiennent l'exposé le plus détaillé des institutions nécessaires à une bonne organisation de la société. [...] pour les rois de Ceylan, la société indienne, telle que la décrivent les dharmaśāstra et les ouvrages d'arthaśāstra, reste le modèle même de la société; ils ne peuvent la concevoir autrement. D'ailleurs, ils sont élevés dans une ambiance purement indienne. Les rites brahmaniques sont pratiqués à la cour. Le couronnement est une institution brahmanique. Pour le futur Dutṭhagāmaṇī, on célèbre la cérémonie de la dation du nom et celle de la première bouchée de riz (nāmadheya [...]; annaprāśana: XXII, 65 et 74), qui sont des samskāra. A la nouvelle de la naissance prochaine de Parakkamabāhu, Mānābharaṇa fit non seulement réciter sans cesse le paritta par la communauté des bhikkhu, mais, dit la chronique (LXII, 33), à la naissance furent célébrés les divers rites prescrits par le Veda (LXII, 45) et, durant son enfance, tous les autres rites (LXII, 53), y compris le cūdākaraña correspondant au sikhāmaha (LXIII, 5) et l'upanayana (LXIV, 13) qui est célébré avec une grande solennité. Il fit également accomplir par des purohita et des brahmanes versés dans le Veda et le Vedanta des sacrifices tels que le homa et d'autres rites tenus pour salutaires. Il est

${ }^{121}$ See also Bechert, 1966: 24. 
donc naturel que les rois de Ceylan se soient tournés vers les ouvrages brahmaniques pour y puiser des conseils sur l'art de gouverner leur royaume. Les réformes accomplies par Parakkamabāhu dans le Dakkhiṇa$\mathrm{d}$,sa quand il fut devenu roi de cette partie de l'île — réformes qui sont décrites dans le Cūlavamsa (LXIX) ... et qui donnent un rare aperçu de l'administration des provinces - sont évidemment inspirées des ouvrages de nīti, l'Arthaśāstra de Kauṭilya et le Code de Manu ... .

The comparison with Sri Lanka is interesting in that Sanskrit never predominated there. ${ }^{122}$ Something like the Indian caste system ${ }^{123}$ survives until today but, as Ryan (1953: 8) points out, "the most significant factor for an understanding of Sinhalese caste structure is not, as is commonly supposed, that the Sinhalese preserved Buddhism, but that the Sinhalese did not preserve the Brahmin". ${ }^{124}$ The subsidiary role of Sanskrit, which is no doubt connected with a feeble presence of Brahmins in historical times, ${ }^{125}$ did not prevent the brahmanical vision of how to run a state from exerting a strong influence on the island. ${ }^{126}$ If Lingat is right, the reason in this case is not the need for legitimation but the absence of a workable

\footnotetext{
${ }^{122}$ There was a Sanskrit presence; see Bechert, 2005; Chhabra, 1935: 12 f. Bechert points out that Sanskrit was and remained a requirement for the study of certain sciences, among them medicine and astrology, and was also used at the royal court; see e.g. Bechert, 2005: 35: "Der Gebrauch des Sanskrit ist in diesen frühen Perioden [i.e. until the 11th century $\mathrm{CE}$ ] ganz deutlich auf einige, genau abgegrenzte Bereiche des kulturelen Lebens beschränkt, nämlich auf den der weltlichen Wissenschaften, den des königlichen Hofes [...] und auf Werke des Mahāyāna-Buddismus sowie des tantrischen Buddhismus." The Sanskrit play called Kundamālā, dating from before the eleventh century CE, may have been composed in Anurādhapura in Ceylon; Dezsó, 2007: 10-11.

${ }^{123}$ Lingat (1989: $89 \mathrm{ff}$.) presents evidence for the presence of caste in Sri Lanka from an early period on. See further Seneviratne, 1978: 9 ff.; Ryan, 1953: 17 ("There is [...] some doubt as to whether the Sinhalese have ever known the plethora of cultural differences, injunctions, tabus, and discriminations which have been the most sensational parts of the Hindu social organization"); Gombrich, 1971/1991: 345 ff. (p. 345-46: "The Sinhalese caste system is historically and conceptually related to the Indian; but there are fewer castes, and there is less scope for ritual pollution through the violation of caste tabus than in India.")

${ }^{124}$ The same, it appears, can be said about modern Pakistan; see Das, 2005.

125 'La présence des brahmanes à la cour du roi de Ceylan est attestée jusqu'à l'époque de Kotṭē (Inscription de Parakkamabāhu VIII au XVIe siècle [...]). Mais leur rôle paraît avoir été éclipsé par le rājaguru, le précepteur spirituel du roi." "Jusqu'à une époque récente, des rois bouddhistes comblèrent les brahmanes de présents. Une inscription de Parakkamabāhu VIII de Kotțē (1484-1518) relate le don du village d'Oruvila à deux purohita". "Jusqu'au règne d'Aggabodhi Ier (568-601) et peut-être même jusqu'à une époque plus tardive, les rois singhalais eurent pour purohita un brahmane à l'instar des rois hindous." (Lingat, 1989: 155, 93, 92)

${ }^{126}$ In medieval times the Mānava Dharmaśāstra and the Arthaśāstra were known in Sri Lanka; see Bechert, 2005: $133 \mathrm{f}$.
} 
alternative. ${ }^{127}$ Perhaps this applied to the countries of Southeast Asia as well, thus contributing to the explanation of the presence of Sanskrit and of Brahmins there.

We see that it will be hard to separate Sanskrit from Brahmins, both in South and in Southeast Asia. The one complicating factor is Buddhism. During most of the period of the Sanskrit cosmopolis, Buddhists appear to have coexisted successfully with Brahmins at the royal courts of Southeast Asia. The question why Buddhists in South Asia adopted Sanskrit for their texts is essentially different, and will be discussed in chapter III.3, below.

Pollock does not deny the presence of Brahmins in the different regions of Southeast Asia. The growth of a class of Khmer Brahmins, he states on p. 222 of his article (1996), is perfectly reasonable, for precisely such a development occurred in Java and Bali. On the same page he notices that Indian Brahmins were occasionally imported, "as for example for the lustration of the Khmer domain in the ninth century". Is it, in view of all this, correct to disconnect the spread of Sanskrit from the spread of Brahmins? At first sight one would think not, but there are some issues that need to be dealt with before a decision can be taken.

It cannot be denied that the first political use of Sanskrit did not take place under the Sātavāhanas, who had a strong (though not exclusive) connection with Brahmanism, but under the western immigrant kings known as Kṣatrapas, whose brahmanical connection was less strong. ${ }^{128}$ What conclusion can be drawn from this? One more look at the inscription of the Kṣatrapa Rudradāman from the second century CE, already referred to above, may be useful. This inscription records the restoration of a lake, called Sudarśana, which had been constructed

\footnotetext{
${ }^{127}$ This appears to be a recurring theme in the history of Brahmanism; cf. Bayly, 1999: 73-74: "By the mid-eighteenth century [the] skill [of scribal Brahmins] had become indispensable to the forms of statecraft which had emerged in the subcontinent's proliferating post-Mughal realms and chiefdoms." Interestingly, other countries - most notably Tibet, China and Japan - had political reasons to adopt Buddhism, this time without Brahmins (Samuel, 2002). It may be significant that these countries looked for political support in tantric forms of Buddhism, which exerted much less influence in Sri Lanka. On the link between Tantrism and political power, see chapter III.8, below.

${ }^{128}$ See already Lévi, 1902.
} 
during the reign of Candragupta Maurya. ${ }^{129}$ Rudradāman's inscription refers back to these earlier events, recalling that the lake had been dug by the governor of Candragupta Maurya and embellished for Aśoka Maurya by the Yavana king Tusāaspha. What strikes us most in the context of our investigation is that the governor of Candragupta is referred to as "the Vaiśya Pusyagupta" (vaiśyena pusyaguptena). ${ }^{130}$ Here, then, there is an explicit reference to a Vaiśya. There is no need to recall that Vaiśyas constitute the third of the four brahmanical varnas: Brahmin, Kṣatriya, Vaiśya, Śūdra. They have their place in society as conceived of in Brahmanism. This brahmanical conception of society became very popular in India, but owed this popularity to Brahmins. The vision of society as being thus hierarchically layered spread with Brahmanism and was an integral and even essential part of it. This raises a puzzling question: Rudradāman's inscription claims that the governor of Candragupta, who ruled more than four centuries before him, had been a Vaiśya. Brahmanism and the brahmanical vision of society had little or no influence in the realm of Aśoka, even less in that of his grandfather Candragupta (see chapter II.3, below). How can we believe that the usual brahmanical division of society played any role at the court of these rulers?

Kielhorn, the editor of the Junāgaḍ inscription, was obviously aware of the problem. He made a feeble attempt to solve it in a footnote (1906: $41 \mathrm{n} .8$ ), stating: "The Vaiśyas according to Varāhamihira are a people of the western division". But a much simpler solution would be to assume that Rudradāman, though not a "brahmanical" ruler in any strict sense, had adopted the brahmanical vision of society. He may not have been the first to do so; perhaps he simply inherited it from his father and grandfather, both mentioned in the original inscription. Having adopted this view, he retroactively assigned previous rulers and their collaborators a place in the brahmanical order of varnas. ${ }^{131}$ Indeed, he refers to "all the varnaas" (p. 43 1.9), and takes care to specify that King Tusāâspha,

\footnotetext{
${ }^{129}$ For a description and depiction of the site, see Falk, 2006: $118 \mathrm{f}$.

${ }^{130}$ Kielhorn, 1906: 43 1. 8; cp. Hinüber, 2004: 990.

${ }^{131}$ This process of retroactive superimposition also appears to be responsible for the attribution of the Arthaśāstra to Kautilya, supposedly the minister of the same Candragupta Maurya. See chapter II.3, below.
} 
who does not fit well into the system, is a Yavana, i.e., presumably a Greek. ${ }^{132}$

It follows that the contrast between Rudradāman and the Sātavāhanas with regard to their brahmanical connections should not be exaggerated. We may have no records of vedic sacrifices being carried out by Rudradāman, ${ }^{133}$ but his inscription does reveal partiality toward Brahmins where it says: ${ }^{134}$ "he, the Mahākșatrapa Rudradāman, in order to [benefit] ${ }^{135}$ cows and Brahmins for a thousand of years, and to increase his religious merit and fame, - without oppressing the inhabitants of the towns and country by taxes, forced labour and acts of affection - by [the expenditure of] a vast amount of money from his own treasury and in not too long a time made the dam three times as strong in breadth and length [...]"

It is clear, then, that Rudradāman knew and honoured Brahmins. He also knew and respected their vision of society as consisting of a number of varnas, one of them being that of the Vaiśyas. ${ }^{136}$ There is therefore no reason to disagree with the following general appreciation: ${ }^{137}$ "It appears that the use of Sanskrit for inscriptions was promoted, though not originated, by the Scythian rulers of northern and western India in the first two centuries of the Christian era. Their motivation in promoting Sanskrit was presumably a desire to establish themselves as legitimate Indian or at least Indianized rulers, and to curry the favor of the educated Brahmanical elite." 138 Indeed, "the shift to using Sanskrit, the Brahmins'

\footnotetext{
${ }^{132}$ Rudradāman's own minister Suviśākha is specified as being a Pahlava (p. 45 1. 19).

${ }^{133}$ It seems unlikely that making their kings perform vedic sacrifices was among the first priorities of the Brahmins scattered over the subcontinent and beyond.

${ }^{134}$ Kielhorn, 1906: 44 1. 15; tr. p. 49. For a description and depiction of the site, see Falk, 2006: $118 \mathrm{f}$.

${ }^{135}$ This is the interpretation suggested by Kielhorn (1906: 49 n. 2).

${ }^{136}$ Pollock (2006: 177-78) himself emphasizes that "the social and [Sanskrit] grammatical orders are related by their very nature". He does so while commenting upon the "semantic coreferentiality" of the expression varna-sthiti ("preservation of language sounds" and "preservation of social orders") which occurs in an inscription from around $1100 \mathrm{CE}$.

${ }^{137}$ Salomon, 1998: 93; emphasis mine.

${ }^{138}$ Lubin (2005: 94) states: "Perhaps the key detail that might throw light on Rudradāman's motive in having this inscription composed in Sanskrit is the description of him as 'having attained wide fame for mastering, remembering, fathoming, and practicing the great sciences of word-and-meaning, music, logic, and so forth' (śabdārthagāndharvvanyāyādyānām vidyānām mahatīnām pāranadhäranavijāānaprayogāvāptavipulakīrttinā [1. 13]). The notion that expertise in the various branches of vidy $\bar{a}$ was the dharma of a ksatriya directly reflects the influence
} 
liturgical language, for the business of state was primarily the initiative of foreign rulers — Scythians and Kuṣānas — anxious to align themselves with a priestly class firmly rooted in Āryāvarta, the 'Land of the Āryas' [...] Once introduced by arrivistes, this policy was fully established as the royal standard by the imperial Guptas."139

Respect for Brahmins in South and Southeast Asia should not be confused with "conversion" to Brahmanism. This is still true at the time of the Pāla rulers of northeast India. We have, for example, a copper-plate grant of the end of the ninth century, in which King Devapāladeva appears as a devout worshipper of the Buddha. In spite of this, he gives a village to a Brahmin of the Aupamanyava gotra and Āśvalāyana śākhā. ${ }^{140}$

The brahmanical vision of society is largely absent in South Asian inscriptions that are not in Sanskrit and whose makers or instigators have no association with Brahmanism. It is absent from the inscriptions of Aśoka. ${ }^{141}$ They refer to none of the four varnas except the Brahmins, nor to the system as a whole. ${ }^{142}$ The same is also true of the early Tamil inscriptions, edited and studied by Iravatham Mahadevan (2003), which concern Jainas but not Brahmins, and depict a society with an "absence of a priestly hierarchy" (p. 162). It is equally true of other inscriptions in Kharoșthī, judging by Konow's index, ${ }^{143}$ and of most non-Sanskrit inscriptions in Brāhmī that precede $150 \mathrm{CE} .{ }^{144}$ Among the exceptions we must count, not surprisingly, Nāsik Cave Inscription no. 2 of the Sātavāhanas, the one which also contains the expression ekabamhaṇa (Skt.

of the brahmanical doctrine of Sanskrit learning as a criterion of high varna. The fact that this Indo-Scythian ruler was one of the first to employ Sanskrit in a political forum suggests that this innovation was a calculated effort to demonstrate publicly the legitimacy of his rule by embracing the sacred authority of the Brahmins."

${ }^{139}$ Lubin, 2005: 94.

${ }^{140}$ Kielhorn, 1892; Barnett, 1926.

${ }^{141}$ There is a passage in the fifth Rock Edict which has sometimes been interpreted as concerning the four varnas. The important words have the form bhatamayesu bambhanibbhesu, with variants. The interpretation of these words is far from obvious. Bloch (1950: 104) does not translate these words, but comments in a note (n. 10): "Très obscur. On a tiré mayesu, ou plutôt mayyesu, de marya, ou de arya avec un -meuphonique; donc 'serfs et nobles, brahmanes et bourgeois': en somme les quatre castes?"

${ }^{142}$ See, e.g., the indexes in Hultzsch, 1925; Schneider, 1978; Andersen, 1990.

${ }^{143}$ See the index in Konow, 1929.

${ }^{144} \mathrm{Cp}$. the index of miscellaneous terms in Lüders, 1912. 
ekabrāhmaña): it has the term khatiya (Skt. kṣatriya), refers to the four varnas (cātuvana), to the twice-born (dija), and even to the (brahmanical) three objects of human activity (tivaga). ${ }^{145}$ Also a number of Pallava inscriptions fall in this category. ${ }^{146}$ Rudradāman, one of the early rulers to refer to the brahmanical (di)vision of society, is also one of the first to use Sanskrit. Is this coincidence? The obvious answer to this question must be: no.

${ }^{145}$ Senart, 1906: 60 1. 4-6. Bhandarkar (1938: 33) proposes to understand the term khatiya as referring to a tribe in northwestern India, but the multitude of brahmanical terms shows that no doubt members of the second varna (Kșatriya) are meant.

${ }^{146}$ It may be useful to recall G. Bühler's (1892: 5) observation concerning a Pallava grant: "Like the great Nānāghāt inscription of Sātakanni's widow Nāyanikā and like the Elliot grant of Vijayabuddhavarman's queen, [our grant] shows that the use of Prākrit in the older inscriptions is not due to the influence of Buddhism, but that in early times Prākrti was the official language of the Indian kings, while the use of Sanskrit was still confined to the Brahmanical schools. Our grant and the other two documents mentioned were issued by adherents of the Brahmanical faith. The use of Sanskrit in the comminatory verses, included in the Elliot grant, and in the mangala at the end of our grant, show that the said language was not unknown to the persons who composed the text. If, nevertheless, the chief portions of the grants are written in Prākrit, some reason, not of a religious nature, must have dictated the use of the vulgar idiom." 


\section{II.3 The brahmanical colonization of the past}

The Brahmanism that succeeded in imposing itself, and its language, on regions that had thus far never heard of it was a reinvented Brahmanism. It was not a simple continuation of the vedic priesthood, but something new that proposed far more than simply executing sacrifices for rulers who needed them. Brahmanism had become a socio-political ideology, but one that disposed of a number of tools in the service of the one ultimate goal: establishing the superiority of the Brahmins in all domains that the ideology claimed were theirs. This included securing their privileged position in virtually all realms connected with the supernatural in all of its forms: predicting the future through reading signs (bodily, astrological, etc.); providing ritual protection on all scales, including the use of curses, talismans, etc.; curing the ill by means of magically efficacious incantations and the like; and so on. It also included counselling rulers in all matters related to society and politics.

Among the methods used by the new Brahmanism to attain its goals we must count the adoption of a new life-style (one aspect of this new life-style will be studied in chapter II.4, below), and the composition of literary works that address both a brahmanical and a non-brahmanical audience to emphasize the features and claims that Brahmins presented as rightfully and inherently theirs. All these tools share one feature: they all deny that the new Brahmanism is new at all. Brahmanism and all that is part of it has always been there, and is the very opposite of new. The sacred language of the Brahmins, for example, came to be thought of as being without beginning: Sanskrit is eternal, the original language that is as old as or older than the world itself. ${ }^{147}$ The same applies to other aspects of brahmanical culture.

This tendency to colonize the past expresses itself in a particularly interesting manner in the way in which Brahmanism came to think of the cause of their past agonies. Remember that the Maurya empire had spelt disaster for Brahmanism. What better way to take revenge than by claiming that this mighty empire, far from almost vanquishing Brahmanism, had obeyed the brahmanical

\footnotetext{
${ }^{147}$ For further ideas about the original language, see chapter III.4, below.
} 
order of things? Rudradāman's inscription, studied in the preceding chapter, shows that this is what he, or his advisors, believed. What is more, the Maurya empire had itself been created by brahmanical acumen. ${ }^{148}$ This claim took shape in the story of Cānakya, the brahmanical minister of Candragupta.

Candragupta Maurya was the creator of the Maurya empire. ${ }^{149}$ Under him and his successors, this empire united under one sceptre most of the South Asian subcontinent and some regions outside it (most notably in what today is called Afghanistan). We have direct evidence of the extent of the Maurya empire thanks to the so-called edicts of Aśoka, Candragupta's grandson. These edicts also provide us with contemporary information about Aśoka's policies and personal thoughts. They are virtually the only contemporary evidence we have on the Maurya empire. Candragupta himself left us no inscriptions, even though there are accounts from outside India, most notably the information (or what is left of it) provided by Megasthenes, the Seleucid ambassador who spent time in Candragupta's capital around the year 300 BCE. Apart from this, we depend on more recent sources, whose historical reliability is not always guaranteed.

We have already seen that Brahmanism found itself at the loosing end of the political unification of northern India. What is more, it had to transform itself in order to survive. In spite of this, the tradition of Cānakya claims the opposite, by stating that a Brahmin created the empire to begin with. Cānakya is furthermore identified with Kautilya, the author of the Arthaśāstra. The Arthaśāstra gives detailed indications on the way a state should be run, and there can be no doubt that its advice has been taken to heart by numerous rulers over the centuries.

This tradition is in obvious conflict with our reflections about the state of Brahmanism under the Mauryas. If it is true that Candragupta and the empire he established spelt disaster for Brahmanism, if it is further true that neither Candragupta nor any of his successors had any interest in Brahmanism, it becomes difficult to believe that this very empire was created by a Brahmin. It is

\footnotetext{
${ }^{148}$ Interestingly, also the creation of the Vijayanagara empire in the $14^{\text {th }}$ century CE came to be (incorrectly) attributed at least in part to a famous brahmanical scholar, MādhavaVidyāranya; see Kulke, 1985.

${ }^{149}$ See e.g. Thapar, 2002: 174 ff.; Witzel, 2003: 78 ff.
} 
possible to believe either that the Maurya empire was a disaster for traditional Brahmanism or that it was created by a Brahmin, but very difficult to believe both at the same time.

These doubts take shape in two questions in particular. Can we use the Arthaśāstra as evidence to find out more about the way Candragupta organized his empire? And is it true that the Maurya empire was created with the indispensable help of a Brahmin minister?

It is important to keep these two questions apart. Theoretically, it is possible that the Maurya empire was created with the help of a Brahmin minister, who was yet not the author of the Arthaśāstra. It is equally conceivable that the Arthaśāstra can justifiably be used to find out more about the way Candragupta organized his empire, without believing that this text, or the whole of it, was composed by a Brahmin.

Consider first the tradition which claims that Candragupta had a brahmanical minister, Cāṇakya, who was instrumental in creating the Maurya empire. Scholars have pointed out that the earliest sources do not mention him, and that the sources that do mention him are separated from the times to which they refer by many centuries. ${ }^{150}$ Moreover, the brahmanical tradition raises the political skills of Cānakya to such a level that there was little for Candragupta to do but follow the advice of his minister. The propagandistic value of this story can easily be appreciated. Future rulers who heard it were reminded of the importance of finding a suitable brahmanical counsellor. In other words, there is a priori little reason to accept this tradition at its face value, and a good deal of reason to suspect that it was invented for propagandistic purposes. It seems advisable to remain wary with regard to the legend of Cānakya.

Let us therefore forget Cānakya, at least for the time being, and turn to the text of the Arthaśāstra. This text has intrigued scholars since its first modern

\footnotetext{
${ }^{150}$ Bongard-Levin, 2001; Trautmann, 1971: 10-67. Willis (2009: $201 \& 325$ n. 163) misleadingly states that the "Milindapañho refers to the clash between the Nandas on one side and Candragupta and Cânakya on the other", with a reference to T. W. Rhys Davids, The Questions of King Milinda, SBE, vol. 36 (Oxford, 1894): 147-48; to my knowledge the Milindapañha contains no such reference.
} 
publication, and attempts have been made to find out whether it is a unitary text, and whether anything sensible can be said about its date of composition.

Regarding the unitary nature of the text, the following observations can be made. The Arthaśāstra consists of verses and prose. Hartmut Scharfe (1968; 1993) has argued that at least two persons left their traces in the composition of this work, one of whom wrote in verse, the other one in prose. Scharfe adduces several arguments in support of this, among them the fact that the contents of the verses do not always agree with those of the prose. The verse text, moreover, calls its author Kautilya in the very beginning and states that he tore away the land of the Nandas at the very end, while the prose text calls itself a compilation in the first line and its author Viṣnugupta in the last. ${ }^{151}$ The exact relationship between the portions of Kautilya and those of Viṣnugupta is not clear. The concluding lines of the text state that Viṣnugupta composed both Sūtra and Bhāṣya. What exactly is meant is again not clear. It is possible that the verses and parts of verses adopted in the prose are referred to as sütras. This custom is adopted in some other texts known to us. ${ }^{152}$

The concluding lines of Viṣnugupta are interesting in this context. They form a verse in $\bar{a} r y \bar{a}$ metre and read:

dṛștvā vipratipattị̣ bahudhā sāastreșu bhāṣyakārānām/ svayam eva viṣnuguptaś cakāra sūtram ca bhāṣam call

The second line means that Viṣnugupta himself made Sūtra and Bhāṣya, which does not exclude the possibility that he borrowed extensively from earlier authors, as we shall see. The first line can be interpreted in different ways. Vipratipatti means basically 'opposition' or 'contradiction'. The line may therefore speak of the opposition of the Bhāṣyakāras against the Sūtra, or against each other. In the first case it concerns an incorrect interpretation of the Sūtra, in the second a difference of opinion among themselves. Another and at least

\footnotetext{
${ }^{151}$ Scharfe, 1968: 80-81. Note that the text is only ascribed to Kautilya in its verses, which, as convincingly argued by McClish (2009: 117; 143 ff.), constitute a later addition.

${ }^{152}$ Among them the Abhidharmakośa Bhāssya and Sthiramati's commentary on the Madhyāntavibhāga Śāstra; see Bronkhorst, 1991.
} 
equally important difficulty lies in the word śāstreșu. Does this word refer to the books, or sciences, on which the Bhāṣyakāras wrote their Bhāṣyas? Another interpretation is possible. The whole line may be understood to speak about the opposition of the Bhāṣyakāras in the Śāstras. ${ }^{153}$ This would mean that the Bhāṣyakāras were at the same time the writers of Śāstras. This is less peculiar than it seems. Viṣnugupta describes himself in the same verse as the author of a Bhāṣya, but he is also the author of a Śāstra, the Arthaśāstra. A parallel case is constituted by the Yoga Bhāsya, which calls itself — including the sütras contained in it — Yogaśāstra. ${ }^{154}$ A Śāstra is in these cases a work which combines sūtras (or kārikās) and Bhāṣya, bringing a number of elements together and uniting them into one. This is exactly what Viṣnugupta's Arthaśāstra says in its first line:

\section{... yāvanty arthaśāstrāṇi pūrvācāryaih prasthāpitāni prāyaśas tāni} saṃhrtyaikam idam arthaśāstrạ̣ krtam

This single (eka) [work called] Arthaśāstra has mainly been made by compiling all the Arthaśāstras produced by earlier teachers. ${ }^{155}$

It seems clear that several authors have contributed to the Arthaśāstra as we now know it. The prose sections may contain parts that derive from various earlier commentators. The statistical investigations of Th. R. Trautmann (1971) do indeed support multiple authorship. ${ }^{156}$ It seems, moreover, safe to say that the text in its present shape is much more recent than the time of Candragupta. Some scholars date it between the middle of the second century CE and the fourth

\footnotetext{
${ }^{153}$ Falk (1986: 59, 58 n. 12) has a third interpretation: "Viṣnugupta sah häufig einen Widerspruch in den Lehren der Kommentar-Verfasser ...".

${ }^{154}$ A further example of this usage is constituted by the buddhist text that calls itself Madhyāntavibhāga-kārikā Bhāṣya, Madhyāntavibhāga-sūtra Bhāṣya and Madhyāntavibhāga Śāstra.

${ }^{155}$ Note that Arthaśâstra 2.10 .63 claims a similar activity for Kautilya: sarvaśāstrāny anukramya prayogam upalabhya ca/ kautilyena narendrārthe śāsanasya vidhih krtah// "After going through all the śāstras in detail and after observing the practice (in such matters), Kautilya has made these rules about edicts for the sake of kings."

${ }^{156}$ For a discussion of Trautmann's methods, see Fosse, 1997: 73-82. On multiple authorship, see also Falk, 1986, esp. p. 69; Bronkhorst, 1991.
} 
century CE. ${ }^{157}$ One scholar, Michael Willis (2009), argues in favour of the most recent of these possible dates, i.e., the fourth century CE. He bases an argument on the fact that Kāmandaki, author of a work called Nìtisāra, celebrates the qualities and achievements of Viṣnugupta, Kāmandaki’s master in polity and statecraft. Viṣnugupta, as we saw, is presented as the name of the author of the Arthaśāstra in its present form. Willis further argues that the opening verse of the Nìtisāra can be understood as an oblique dedication to Candragupta II, the Gupta ruler who ruled circa CE 375-415. He concludes from this that "the archaeological and textual evidence points to a date in the mid-fourth century for the Arthaśāstra" (Willis, 2009: 62). ${ }^{158}$ Even if we remain prudent with regard to Willis's final conclusion, it seems clear that the Arthaśāstra as we now know it does not date from the time of Candragupta Maurya.

Are we at least entitled to accept the attribution of some portion of the text to a minister of Candragupta Maurya? This is highly improbable. The fact that no writing was used in India at the time of Candragupta Maurya is one reason to entertain doubts. ${ }^{159}$ Another one is that the Arthaśāstra presupposes a kingdom that can be surrounded by more powerful rivals, whereas the empire of Candragupta Maurya and his successors could not be encircled. ${ }^{160}$ Then there is the obvious advantage, already pointed out before, which more recent Brahmins could derive from the claim that the Maurya empire - which had not been sympathetic to them — had really been created by a Brahmin, using the methods which those more recent Brahmins promoted among their contemporaries.

\footnotetext{
${ }^{157}$ So Willis, 2004: 57 n. 114. It dates from "the first or perhaps the second century A.D." according to Scharfe (1993: 293).

${ }^{158}$ Willis (2009: 170) cites and translates the relevant verses of the Nittisāra, and it is clear from these that they can be read as indicating that Viṣnugupta destroyed the Nandas and created an empire for Candragupta: yasyābhicāravajrena vajrajvalanatejasah/ papāta mūlatah śrīmān suparvā nandaparvataḥ/l ekākī mantraśaktyā yah śaktyā śaktidharopamah/ ājahāra nrccandrāya candraguptāya medinīm// nītiśāstrāmṛtam dhīmān arth [a]śāstramahodadheh/ samuddadhe namas tasmai viṣnuguptāya vedhase// "Obeisance to [that] Viṣnugupta, whose magical spell, splendid as a flash of lightning, uprooted the foundation of the mountain-like Nanda, prosperous and powerful; who, like the weapon-bearing Kārttikeya, used his weapon of wise counsel to single-handedly secure the world for Candragupta, that prince among men; salutations to that author, who produced the nector of Nìtiśastra out of the mighty ocean of Arthaśāstra."

${ }^{159}$ Note that the Arthaśāstra (2.10 and elsewhere) is familiar with writing and scribes (lekhaka).

${ }^{160}$ Fussman, 1987-88: 46.
} 
We still have to consider the possibility that the oldest core of the Arthaśāstra was not composed by a Brahmin (or by Brahmins), and may therefore conceivably preserve traces of the way the Maurya empire (whether the empire of Candragupta Maurya or that of one of his successors) was organized. A doctoral dissertation recently submitted to the University of Texas at Austin, by Mark McClish (2009), is highly relevant in this context. McClish comes to the conclusion that "the ideology of Brahmanism, which promotes the political interests of the brahmanical community, was a later addition to a text previously devoid of such concerns" (p. vi). There was, he claims (p. 317), "sometime around the turn of the millennium, a comprehensive articulation of the state (within śâstric convention) that displayed little, if any, evidence of the political interests of the brahmanical community (the so-called 'prakarana-text'). And, in one major overhaul (the adhyāya redaction), a religious ideology had been inserted into the text sufficient to recast the entire project of statecraft as being carried out within a greater religious order."

I find McClish's arguments on the whole convincing. We must however keep in mind that he would be the last to claim that the prakarana-text is the original or earliest Arthaśāstra; it seems to preserve traces of interpolations, even though a reconstruction of an even earlier text seems for the time being impossible. The prakarana-text as McClish has reconstructed it, though free from evidence of the political interests of the brahmanical community, is not altogether free from brahmanical elements. Indeed, McClish believes (p. 310) "that it would be erroneous to draw the conclusion that the prakaraṇa-text of the Arthaśāstra is somehow anti-brahmanical or non-brahmanical. ... On the contrary, the text seems to assume a privileged social position for Brahmins, even though it does not address it in its policy or law. Moreover, the king's prime minister, the mantripurohita, his astrologers, diviners, and many other functionaries were almost certainly Brahmins." The prakarana-text may well be "a text written by Brahmins and possibly also for Brahmins, at least in part" (p. 311). The fact that it was composed in Sanskrit further supports this assumption. But judging by its contents, “it doesn't appear that varnadharma had made a very large impression on kings and states in the period in which it was composed" (p. 312). 
The prakarana-text, then, was not a text used in organizing the Maurya empire. Quite on the contrary, it represents an earlier and as yet less confident brahmanical attempt to develop a śāstra on statecraft. As such, it is an exceedingly important and interesting historical document, but not, I repeat, because it supposedly tells us something about the Maurya empire: it does not. ${ }^{161}$ It does, on the other hand, appear to provide us with information about the early development of Brahmanism as a socio-political ideology, a topic that deserves more attention than can be given to it here.

The Arthaśāstra, then, may not be a reliable source for finding out the way in which Candragupta's empire was run. If our earlier reflections are right, it is rather an expression of the brahmanical reaction against the political changes his empire had brought about. It was because of the Maurya empire that Brahmanism had to reinvent itself. It was because of that empire that Brahmanism transformed itself from a ritual tradition linked to local rulers in a relatively restricted part of India into a socio-political ideology that succeeded in imposing itself on vast parts of South and Southeast Asia, together covering an area larger than the Roman empire ever did.

If, then, the Arthaśāstra is not a reliable source of information for Candragupta Maurya and his empire, are there other sources that are more reliable? There are, and a particularly important one is the testimony left by Megasthenes, a Greek visitor who spent time at the court of Candragupta Maurya, in Pātaliputra. Megasthenes was an ambassador of king Seleucus, and wrote a book containing his observations on India, fragments of which have survived in the works of other Greek authors. We will see that the picture we can derive from this text agrees in a crucial respect with the picture presented so far.

\footnotetext{
${ }^{161}$ In McClish's words (p. 315 n. 472): “[W]hat we have in the Arthaśāstra is not a description, nor even an idealization, of any given historical state. It is a set of intertwined, exhaustive refractions of the state within the contours of śâstric priorities." McClish finishes his study with the following cautious words (p. 328): "Whether any part of [the Arthaśāstra] may be used for the Mauryan period is as yet unclear. Considerations for dating the prakarana-text certainly deserve their own study once the character of its composition is known more clearly."
} 
The no doubt most puzzling feature of the testimony left by Megasthenes is his account of Indian society as being composed of seven classes, viz., the philosophers, farmers, shepherds and hunters, artisans and tradesmen, warriors, inspectors, and advisers and councillors. Numerous modern scholars have racked their brains trying to make sense of this enumeration. A number of them have tried to bring this list in agreement with the traditional brahmanical division of society into four varnas, others, in desperation, have claimed that Megasthenes imposed categories that he had brought from Egypt or somewhere else. ${ }^{162}$ No one seems to have stated what seems now obvious, viz. that Megasthenes spent time in Magadha during a period when this region had not yet been brahmanized. Megasthenes' puzzling enumeration constitutes in this way a striking confirmation of our point of departure, viz., that the region of Magadha had not been brahmanized at the time of Candragupta. Recall that brahmanization means, first of all, the imposition of the brahmanical vision of society, typically into four varnas. In Magadha, at the time of Candragupta, people did not think of themselves as being hierarchically organized in this particular manner, just as people of the same region had not thought of themselves in that manner at the time of the Buddha. Indeed, at the time of Candragupta, the brahmanization of society still belonged to a distant future.

The preceding reflections show that the new picture of Candragupta and his empire that is emerging is not quite the same as the one cherished by tradition. The tradition, moreover, is clearly a brahmanical tradition, whose purpose was altogether transparent: to project back into the past a picture of the role Brahmins have to play in creating and governing a kingdom. The fact that the legend of Cānakya is not confined to brahmanical sources merely testifies to the fact that this reconstruction of the past was not confronted with organized opposition. Even the Buddhists, who glorified the memory of Emperor Aśoka as a buddhist ruler, mention the name of Cāṇakya (Cāṇakka in Pāli) in their Mahāvaṃsa (5.16). The rule of the Mauryas, it appears, was remembered in various ways by Brahmins and Buddhists alike. Rudradāman's inscription, considered earlier,

${ }^{162}$ See Karttunen, 1997: 82-87. 
provides further evidence for this, for it refers to Candragupta Maurya and several events and persons of his time. This shared memory, it appears, could be moulded by Brahmins in a manner that suited their purposes. Such colonization of the past became all the easier in later days when the influence of Brahmins at the court had become a fact with which all were familiar. We will see in a later chapter (III.5) that the Buddhists of the subcontinent came to reformulate their own past in brahmanical terms. Accepting that the Maurya empire had been created with the help of a brahmanical minister may have come to be looked upon as natural, even by Buddhists. 


\section{II.4 The brahmanization of borrowed features}

One important aspect of the new Brahmanism has not as yet been discussed. Brahmanism made a major effort to assure its separate identity. Codes of behaviour were adopted that guaranteed that Brahmins would always stand out and be thought of as examples incorporating values and principles that were there for others to imitate, or respect. Part of the literature created by Brahmanism during the centuries around the beginning of the Common Era - such as the Dharma- and Gṛhya-sūtras — is primarily directed at Brahmins themselves, and details the behaviour they are supposed to adopt at all times.

A detailed study of this literature and of its significance for the new Brahmanism must be postponed to another occasion. The present chapter will concentrate on one feature of renascent Brahmanism, its association with the hermitages called āśramas. This particular feature, it will be argued, was no brahmanical invention, but an adaptation of a notion borrowed from the religions of Greater Magadha.

We have seen that at least from the time of the Mauryas on, shelters came to be created for the ascetic members of the religious movements of Greater Magadha, primarily the Jainas, the $\bar{A} j \bar{j}$ vikas and the Buddhists. Initially these gifts were presumably just shelters created for the ascetic members of these communities, where they might spend the rainy seasons. In due time these shelters were also allowed to profit from the produce of a piece of land or of a village. In such cases the donor, normally the ruler or someone close to him, stipulated that the revenue that would normally accrue to him in the form of taxes would henceforth be used for the upkeep of the shelter and for feeding its inhabitants.

The Brahmins could not profit from this largesse. In order not to loose out, they created a new brahmanical institution out of thin air, so to say. They invented the brahmanical hermitage, áśrama in Sanskrit. The thesis here to be explored is that hermitages are the brahmanical response to the dwellings, later 
monasteries, of buddhist and jaina ascetics, places that were frequent objects of generosity. ${ }^{163}$

Monasteries, whether buddhist or other, are not always totally and exclusively dedicated to spiritual pursuits. But ideally they are. And without the ideal, monasteries would not benefit from donations provided by the rich and powerful.

With this in mind, let us consider brahmanical hermitages. Their depiction in brahmanical literature is almost without exception idyllic. ${ }^{164}$ An example is provided by the probably best known âśrama, the one described in Kālidāsa's famous play Abhijñānaśākuntala. This play contains a scene in which King Dusyanta, in hot pursuit of an deer, is stopped with the words: ${ }^{165}$ "No, no Your Majesty! Don't kill him, he's a deer of the hermitage." It turns out that Duṣyanta, without realizing it, has come close to the hermitage of the sage Kanva where, we now learn, deer cannot be killed. The king is subsequently invited to visit the hermitage and does not fail to recognize the signs:

Those grains of wild rice beneath the trees must have dropped from fledgling mouths in parrots' nests, While the oily stones here and there must have been used for crushing ingudī nuts.

The deer are so trustful their pace doesn't alter at the noise of our approach,

And on the paths from the pool clothes made of bark have dripped long trails of water. (tr. Coulson)

Hermitages obey different rules of behaviour than other parts of the kingdom, rules which even the king must obey. Yet a hermitage, too, needs the protection of the king. This is clear from the compliment which Dusyanta receives from one of its inhabitants: "By seeing how the ascetics' holy rites are free of all hindrance,

\footnotetext{
${ }^{163}$ This thesis is not altogether new. Witzel (2006: 476 n. 57) wonders "whether the forest idylls of the [Mahābhārata] (such as that of Śakuntalā and her stepfather Kānva) are, in reality, a copy of the jaina practice of establishing ascetic's dwellings (or caves) in the south". The thesis presented in this chapter does not exclude that shelters, of whatever kind, were also provided in the North, and also to ascetics who were not Jainas, already during the centuries preceding the Common Era.

${ }^{164}$ See, e.g., Shee, 1986: 306 f.; Pontillo, 2009.

${ }^{165}$ Tr. Coulson, 1981.
} 
you will realize how much your bow-scarred arm protects."166

Hermitages of this kind, i.e. places inhabited by ascetically inclined Brahmins, are a common feature of brahmanical literature. They are frequently mentioned in the two Sanskrit epics - the Mahäbhārata and the Rāmāyaṇa and in more recent brahmanical literature, but not in the vedic Saṃhitās, Brāhmaṇas and early Upanișads. ${ }^{167}$ This raises the question: how, when and why did this institution arise? Is it true that "[m]ost of even the largest äśrama-s [...] began as a simple dwelling of a sādhu who had ceased travelling and settled, frequently after many years of pilgrimage to holy places throughout the Indian subcontinent"? ${ }^{168}$ This chapter will explore the alternative possibility suggested above.

Romila Thapar (2005: 164) makes the following observation about Kālidāsa's play: "The āśrama of the Kanvas carries traces of a new incipient institution which was to develop into the agrahäras of post-Gupta times, institutions which changed the socio-economic landscape. Tax-free land was donated by the king for settlement by brāhmaṇas which could be in areas already

\footnotetext{
${ }^{166}$ The manner in which Dusyanta, wishing to conceal his identity, initially presents himself suggests that beside protection also supervision of hermitages was the responsibility of rulers. Dusyanta initially claims to have been appointed by the king to the office of Superintendent of Religion (dharmādhikāre niyukta). For a discussion of this function here and elsewhere, see Sanderson, 2009: 104-105 n. 220.

167 "In the older vedic literature the word āśrama in the sense of a hermitage seldom occurs. Virtually the only example of the word in a śruti-text is an aśrama called Vasișthaśilā in Gopathabrāhmaṇa 1,2,8." (Tsuchida, 1991: 79-80; similarly Olivelle, 1993: 18).

${ }^{168}$ Clark, 2006: 29. It is possible to wonder, with Annemarie Mertens (2005: 255 n. 95), whether there really were brahmanical ascetics. As she puts it: "Denkbar wäre ..., dass [die brahmanischen Asketen] lediglich ein weiteres 'Konstrukt' der beiden Gruppen (i.e., Brahmins and Buddhists, JB) darstellen, das ihnen zur eigenen Profilierung diente". It would indeed be interesting to know whether the ecological conditions of the Indian subcontinent make it possible for an individual to survive on nothing but the fruits and roots which he comes across in his corner of the forest, without any access to the agricultural products of society (and without the use of animal products); yet this is what the normative texts suggest. Wrangham (2009: ch. 1) shows that survival in the wild without cooking is scarcely if at all possible for humans. And the BBC television series "Wild Food" by Ray Mears (2007) reminds us of the massive amount of time huntergatherers require to find and prepare their food; this hardly corresponds to the image of the peaceful life of the brahmanical ascetic in his âsrama who, moreover, is not supposed to hunt.
} 
under cultivation or newly opened to cultivation. These were to become powerful nuclei and networks of brahmanical culture."

Thapar's remark suggests that two initially different institutions started influencing each other at the time of Kālidāsa, that people began to think of $\bar{a}$ śramas as being similar to agrahäras even though they were originally different from each other. But is this correct? Were āśramas and agrahāras originally different institutions that subsequently came to influence each other, or were they rather, right from the beginning, two aspects of one and the same institution? Or is the historical situation perhaps more complex than either of these two possibilities?

At first sight the Arthaśāstra appears to support the view that two different institutions are involved. In its chapter on the settlement of the countryside this text states: ${ }^{169}$ "He should grant [lands] to priests, preceptors, chaplains (purohita) and Brahmins learned in the Vedas [as] gifts to Brahmins (brahmadeya), exempt from fines and taxes, with inheritance passing on to corresponding heirs, [and] to heads of departments, accountants and others, and to gopas, sthānikas, elephanttrainers, physicians, horse-trainers and couriers, [lands] without the right of sale or mortgage." This passage speaks about brahmadeyas, a term which is close in meaning to agrahāra and is sometimes compounded with it in the early sources (brahmadeyāgrahāra; see below). Another passage of the Arthaśāstra speaks about land to be given to ascetics (tapasvin): ${ }^{170}$ “On land unsuitable for agriculture, he should allot pastures for cattle. And he should grant to ascetics wildernesses (aranya) for Veda-study and soma-sacrifices, with safety promised to [everything] immovable and movable in them, one goruta at the most."

As stated above, two different forms of land grants seem to be spoken about in these passages, which might be characterized, respectively, as rewards for past (and perhaps ongoing) services, and as support for future religious

\footnotetext{
${ }^{169}$ Arthaśāstra 2.1.7: ṛtvigācāryapurohitaśrotriyebhyo brahmadeyāny adạ̣dakarāny abhirūpadāyādakāni prayacchet, adhyakṣasaṃkhyāyakādibhyo gopasthānikānīkasthacikitsakāśvadamakajañghākārikebhyaś ca vikriyādhānavarjāni. Ed., tr. Kangle.

${ }^{170}$ Arthaśāstra 2.2.1-2: akrșyāyām bhūmau paśubhyo vivītāni prayacchet/ pradiș̣ābhayasthāvarajangamāni ca brahmasomāranyāni tapasvibhyo gorutaparāṇi prayacchet//. Ed., tr. Kangle. This is the beginning of the Prakarana called Bhümicchidrāpidhāna, on which see Hinüber, 2005: $491 \mathrm{ff}$.
} 
practices. The āśrama in Kālidāsa's play apparently belongs to the second category.

The Arthaśāstra also speaks of áśramas in the sense 'hermitage'. They may need adjudication in the royal court (1.19.29), they figure in a list of isolated places (2.35.14), in conquered territory they must be honoured (13.5.11). Here one's first impression is that these âśramas should be connected with the second category of donated land.

But let us not jump to conclusions. Brahmins can be the beneficiaries of both kinds of land grants. Indeed, given that Veda-study and soma-sacrifices are brahmanical activities, we must assume that Brahmins were the ones that would primarily profit from the second kind of land grant; they are also explicitly and prominently mentioned in connection with the first kind. If we now confine our attention to the Brahmin recipients of both kinds of grants, we have to ask what difference it would make to receive one or the other. The Brahmins listed to receive the first kind of land grant are priests ( $r t v i j)$, preceptors ( $\bar{a} c \bar{a} r y a)$, chaplains (purohita) and Brahmins learned in the Vedas (śrotriya). All of these are presumably involved in vedic study and vedic ritual. It goes almost without saying that, from the point of view of the Arthaśāstra, they will continue these activities if and when they retire to the land that has been granted to them. Like the ascetics, they too will be involved in Veda-study and sacrifices, whether soma-sacrifices or other kinds. It follows that, at least in theory, the end result of the two kinds of land grants to Brahmins is very similar, for both types of Brahmins are expected to continue carrying out their ritual activities and Veda studies.

The buddhist canon, too, makes a distinction, this time between Brahmins who have received a brahmadeya (brahmadeyya in Pāli) and those who live in āśramas (Pāli assama): the former are often depicted as being rich, the latter as ascetics. ${ }^{171}$ However, the opposition may have to be taken with a grain of salt, as it was apparently already by the composers and editors of the buddhist Suttas.

\footnotetext{
${ }^{171}$ Tsuchida, 1991. On pp. 56-57 Tsuchida gives a list of brahmadeyas figuring in the Nikāya texts; see also Wagle, 1966: 18-19. Note that the mention of these two kinds of Brahmins in the buddhist canon does not necessarily imply that they existed already at the time of the Buddha.
} 
Tsuchida, describing the ascetic Keniya, is led to observe (1991: 82): "we must admit that the Keniya depicted in the Sela-sutta exhibits several features which do not fit with the image of a hermit. For instance, one who was capable of giving a feast for one thousand two hundred and fifty monks all at the same time could hardly have been found even among the mahāsāla-Brahmins, [not] to say anything of the hermits." Tsuchida attributes these features to the narrator's exaggeration or even caricaturization, "which blurs to no small extent the essential difference between Keniya and those wealthy Brahmins living in villages". This may be correct, but the exaggeration may also be explained by the fact that the narrator knew that there was a continuity between these two kinds of Brahmins, and therefore that the difference between them was not all that essential. Both, at any rate, were preoccupied with vedic ritual in various forms, and with the transmission of vedic texts. ${ }^{172}$

The importance of ritual activities and Veda studies in the case of recipients of agrahäras is confirmed by inscriptional evidence from various periods. A copper-plate from Gujarat, dated $812 \mathrm{CE}$, specifies that a local ruler donates a village to a number of Brahmins "for the increase of the religious merit of my parents and of myself; for the sake of acquiring a reward in this world and in the next; [and] for maintaining the bali, the caru, the vaiśvadeva, the agnihotra, the sacrificial rites, etc." ${ }^{173}$ Bali, to cite Apte's dictionary, is the offering of a portion of the daily meal of rice, grain, ghee \&c. to all creatures, caru the oblation of rice or barley boiled for presentation to the gods and the manes, vaisvadeva an offering to all deities. The maintenance of the bali, caru, vaiśvadeva, agnihotra and other rites is a frequent theme in inscriptions. It is, for example, the reason for the gift of a village to a Brahmin recorded on copper plates from Baroda dated 609 or 610 CE. ${ }^{174}$ Another inscription on copper-plates from Gujarat, this one

\footnotetext{
${ }^{172}$ Perhaps a distinction can be made between recipients that live on the land or in the village which they receive, and those who don't. The inscriptional evidence sometimes suggests that a donee may live somewhere different from the village which he receives, as in the case of a fifth-century inscription from Gujarat, in which the Brahmin Naṇnasvāmin, residing in Kāpura, receives "the village Kanīyas-Taḍākāsārikā included in this same district" (atraiva vișayāntargata-Kanīyas-Tadākāsārikā-gramo; E. Hultzsch in EpInd 10 (1909-10), p. 53-54).

${ }^{173}$ J. F. Fleet in EpInd 3 (1894-95), 53-58.

${ }^{174}$ F. Kielhorn in EpInd 6 (1900-01), 294-300.
} 
dated 910-911 CE, concerns the gift of a village to a Brahmin "in order [to enable the donee to perform] the bali, caruka and vaiśvadeva". ${ }^{175}$ Sometimes a village is donated to a Brahmin "who keeps alive the sacred fire (ähitägni), [...] knows the whole Veda, [and] delights in the six duties [enjoined on Brahmins]." ${ }^{176}$ An inscription from around $540 \mathrm{CE}$ makes reference to a grant to several Brahmins for enabling them to offer the five mahāyajñas, i.e., bali, caru, vaiśvadeva, agnihotra and havana. ${ }^{177}$ The five mahāyajñas are specified in the Mānava Dharmaśāstra in the following manner: "The sacrifice to the Veda is teaching; the sacrifice to ancestors is the quenching libation; the sacrifice to gods is the burnt offering; the sacrifice to beings is the Bali offering; and the sacrifice to humans is the honouring of guests." ${ }^{178}$ Providing for the expenses of the five great sacrifices, i.e., the five mahāyajñas, is a common purpose of donations. ${ }^{179} \mathrm{We}$ find it in a copperplate inscription from Bengal dated $488 \mathrm{CE}$ and elsewhere. ${ }^{180}$ The village Cūkutțūr was donated in the fifth century CE to seventy-four Brahmins for the purpose of vedic study, performing sacrifice and teaching. ${ }^{181}$ The Cambay plates of Govinda IV, dating from $930 \mathrm{CE}$, contain a long specification of the

${ }^{175}$ E. Hultzsch in EpInd 1 (1892), 52-58.

${ }^{176} \mathrm{~F}$. Kielhorn in EpInd 6 (1900-01), $18 \mathrm{ff}$.

${ }^{177}$ Sten Konow in EpInd 10 p. 74: bali-caru-vaiśvadevāgnihotra-havana-pañcamahāyajña-kriyotsarpanārtham. Konow translates (p. 76): "for the maintenance of the five great sacrifices, (viz.) bali, caru, vaiśvadeva, agnihotra (and) havana, and of (other) rites". Kane, HistDh II, 2 p. 854, referring to this passage, interprets it differently, saying "for enabling them to offer bali, caru, vaiśvadeva, agnihotra and the five mahāyajñas" (my emphasis). Virtually the same expression occurs also elsewhere, for example in an inscription from 736 CE (G. V. Acharya in EpInd 23 (1935-36), p. 152 lines 36-37: balicaru-vaiśvadevāgnihotrātithi-pañca-mahāyajñādi-kriyotsarpaṇārthaṃ; Acharya translates (p. 154-55): "for the purpose of performing the five great sacrifices, viz., bali, caru, vaiśvadeva and atithi”). Cf. Njammasch, 2001: 289.

${ }^{178}$ Manu 3.70: adhyāpanam brahmayajñah pitryajñas tu tarpanam/ homo daivo balir bhauto nryajño 'tithipūjanam//. Ed. tr. Olivelle. Nalinikanta Bhattasali in EpInd 18 (1925-26), p. 78 n. 9 observes: "Of these [five great sacrifices specified in the Manava Dharmaśästra], the 2nd, 3rd and 4th (which are equivalent to caru, bali and sattra) appear to have been the most important, and the term bali-caru-sattra-pravartanam (i.e. establishment of bali, caru and sattra) came to mean the establishment of a householder." ${ }^{179}$ See, e.g., H. H. Dhruva in EpInd 2 (1894), p. 22; Datta, 1989: 92. The fact that the mahāyajñas, unlike śrauta rites, are for the benefit of virtually all inhabitants of the universe ("the Creator, the ancient sages, the Manes, the whole universe with myriads of creatures of various grades of intelligence"; Kane, HistDh II, 1 p. 697) may explain to at least some extent this popularity.

${ }^{180}$ N. G. Majumdar in EpInd 23 (1935-36), 52 ff.

${ }^{181}$ Chauhan, 2004: 89, with a reference to K. V. Ramesh, Inscriptions of the Western Gangas, Delhi 1984, p. 23. 
purposes for which the village Kevañja is granted to a Brahmin called Nāgamārya: "for the purpose of (maintaining) the bali, caru, vaiśvadeva and atithitarpana; for the performance of the optional, indispensable and occasional rites; for the performance of the śräddha and sacrificial ceremonies such as the darśapūrṇamāsa, cāturmāsya, aștakā and āgrayaṇa (rites) and the fortnightly (śrāddhas); for the purpose of preparing the caru, purodāśa, sthālīpāka and so forth; for the purpose of (granting) priestly fees and gifts in connection with homa, niyama, the study of one's own Veda, and religious service; for the purpose of (providing) accessory assistance for the rites concerning rājasūya and the seven forms of the soma sacrifice such as the väjapeya, agniștoma and so forth; for the purpose of (offering) garments, ornaments, entertainment, gifts, sacrificial fees, etc. to the various priests, such as Maitrāvaruna, Adhvaryu, Hotr, Brāhmaṇācchamsin, Grāvastut and Agnidh; and for the purpose of (supplying) the requisite materials for preparing sattra, prapa $\bar{a}$, pratiśraya, vṛ̣otsarga, reservoirs, wells, tanks, orchards, temples, etc." ${ }^{\prime 82}$ Most inscriptions are not quite as specific as this, but we may assume that it gives expression to the purpose that is behind many if not most other donations of land to Brahmins. ${ }^{183}$

An inscription from the end of the seventh century CE and originally put up somewhere in the northwest records the erection of a building for Brahmins familiar with the three Vedas; the way in which the place is described - "where the quarters of the heavens are deafened by the noise of the constant explanation of vedic lore" (samtatavedavyākhyānaghoṣabadhirīkrtadinmukha) — shows that its donor, a certain Harivarman, intended to further promote this activity. ${ }^{184} \mathrm{~A}$ pillar inscription from Mysore that may be assigned to the first half of the sixth century CE tells us that a king had a great tank made at a spot "which is ever praised with auspicious recitations of sacred texts by Brahmin students solely devoted to manifold vows, sacrifices and initiatory rites" (vividha-niyama-homa-

\footnotetext{
${ }^{182}$ D. R. Bhandarkar in EpInd 7 (1902-03), 26-47.

${ }^{183}$ Cp. Lubin, 2005: 95: “The recipient's qualification for such patronage, wherever it was mentioned, was his training in textual recitation and the application of mantras in ritual performances, or expertise in a learned discipline such as grammar, logic, law, astrology, or poetics. The authority of the Brahmin was thus explicitly justified, in principle anyway, by his mastery of sacred knowledge."

${ }^{184}$ F. Kielhorn in EpInd 1 (1892), 179-184.
} 
dīkșā-parair brāhmanai snātakai stūyamāne sadā mantra-vādais śubhaih) ${ }^{185} \mathrm{It}$ seems implied that the pious act of the king is meant to encourage these Brahmins to continue these activities. An inscription from the area of Baroda dated in the middle of the twelfth century CE recalls the fact that King Kumārapāla ordered that ramparts be built for the city of Nagara-Ānandapura; the benefit is mutual, for "there the Brahmins [...] protect the king and the realm and guard them by sacrifices that ward off evil and cause prosperity". ${ }^{186}$ A copper plate inscription from the south, dated at the beginning of the sixth century $\mathrm{CE}$, renews the gift of a village to eight Brahmins "who are engaged in performing and helping others to perform sacrifices, in study and in teaching, and in making and receiving gifts". 187 The link between sacrifices and the well-being of political power is clear from an inscription from the eighth century CE which mentions a Mahārāja Mādhavavarman "who washed off the stains of the world by his ablutions after eleven aśvamedha sacrifices, who celebrated thousands of sacrifices, who by a sarvamedha sacrifice obtained the supreme dominion over all beings, who celebrated a hundred thousand bahusuvarna, pauṇ̦arīka, purușamedha, vājapeya, yūdhya (?), șodaśin, rājasūya, prādhirājya, prājāpatya and various other large and important excellent [sacrifices], who by the celebration of excellent sacrifices attained to firmly established supremacy". ${ }^{188}$ A copper plate inscription in Prakrit from the Telugu country "to be assigned to a much earlier period" than the eighth century $\mathrm{CE}$ records the donation of a village to two Brahmins "for conferring on ourselves victory [in war] and for increasing [our] merit, length of life, and power". ${ }^{189}$ Other copper plates in Prakrit, these ones dating from around the year $100 \mathrm{CE}$, state confidently: "Fortune, wealth, power and victory were given [by the donees to the king as a reward for the grant]." ${ }^{, 190}$ The Junagadh Rock inscription of Skandagupta from the middle of the fifth century CE expresses the wish that a certain city "may become prosperous, full of inhabitants, cleansed

\footnotetext{
${ }^{185}$ F. Kielhorn in EpInd 8 (1905-06), 24-36.

${ }^{186}$ Vajeshanker G. Ojhā in EpInd 1 (1892), 293-305.

${ }^{187}$ G. V. Srinivasa Rao in EpInd 24 (1937-38), 47-52.

${ }^{188}$ F. Kielhorn in EpInd 4 (1896-97), 193-198.

${ }^{189}$ E. Hultzsch in EpInd 6 (1900-01), 84-89.

${ }^{190}$ E. Hultzsch in EpInd 6 (1900-01), 315-319.
} 
from sin by prayers (brahman) sung by many hundreds of Brahmins". ${ }^{191}$ A stone inscription from Sirpur to be dated in the 8th or 9th century CE states clear conditions with regard to the descendants of the twelve Brahmins who receive a share in the villages there specified: "Their sons and grandsons [who succeed them] should be such as offer sacrifice to fire and know the six supplements of the Vedas, who are not addicted to gambling, prostitutes and such other [bad associations], who have their mouths clean and who are not servants. If one does not answer to this description, [he should be abandoned]; also one who dies sonless — in their places must be appointed other Brahmins possessing the foregoing qualifications". 192

Gifts of land to Brahmins, as these and other inscriptions suggest, were not merely rewards for services rendered in the past but also spiritual investments for the future. ${ }^{193}$ This explains why Brahmins could receive agrahāras without having a voice in policy decisions. ${ }^{194}$ The purpose of these gifts - to cite Burton Stein (1980: 146) — was "to provide a reliable source of support to Brahmins for the pursuit of their sacral responsibilities". The benefit was mutual and concerned the donor as much as the donee. This implied that donors would look for Brahmins who could be considered the best investments. ${ }^{195}$ Theoretically it also meant that Brahmins would not accept donations of land from unworthy kings. We do not know how many Brahmins actually refused a land grant for this reason, but we do know that Kalhana's Rajjataraingiṇi (1.307) looks down upon the Brahmins from Gandhāra for this very reason: they accepted agrahāras from a worthless king.

The sacral responsibilities of the Brahmins in their agrahāras usually concerned rites they could carry out on their own. Grants of land or villages are

\footnotetext{
${ }^{191}$ Fleet, 1887 (CII 3), pp. 56-65.

${ }^{192}$ Rai Bahadur Hira Lal in EpInd 11 (1911-12), 184-201.

${ }^{193}$ Honoring Brahmins - as Manu 7.82-83 reminds us — is an inexhaustible treasure (aksayo nidhih), which neither thief nor enemy can steal, and which never perishes.

${ }^{194}$ This may have been the case in the Maitraka kingdom of early medieval Gujarat; Njammasch, 2001: 288.

${ }^{195}$ A late copper-plate inscription speaks of Brahmins who are "fit to receive land-grants" (bhüdānapātrabhūta); Gopinatha Rao in EpInd 18 (1925-26), p. 167 1. 62-63. Cp. Manu 7.86. Already some Dharmasūtras (Gautama 11.11; Vasiștha 1.44) point out that the king takes a share of the merits of Brahmins, or a sixth part of their sacrifices and good works.
} 
rarely associated with the Brahmins' participation in solemn vedic rituals. Kings sometimes boast of having performed major sacrifices such as the aśvamedha, but these are not the sacrifices which Brahmins perform in their agrahäras. This would normally not even be possible, for such solemn rites require Brahmins from various Vedas, plus of course a yajamāna, preferably the king himself. Solemn rites were performed by some rulers, but they are not normally the reason why agrahāras were given. Land or villages were not given in order to secure the presence of Brahmins who might then perform the major vedic sacrifices. There are some indications suggesting that Brahmins invited to participate in a vedic sacrifice might afterwards return home. ${ }^{196}$ Such invitations and visits were not in need of official deeds, and would therefore not leave traces in the epigraphic record.

The donors - in the case of land grants very often kings, queens or others close to the centres of political power - were keen to emphasize their generosity; surviving inscriptions, which typically represent their point of view, deal exhaustively with this side of the transaction. Inscriptions, to be sure, were not normally composed by kings and other power brokers themselves, but they were very often composed for them and in their name.

The Brahmin donees had other concerns. For them it was vital to show that land gifts were good spiritual investments. They did so by depicting the life in Brahmin settlements as being profoundly religious, with an emphasis on all those activities (ascetic practices, vedic sacrifices) which were held to benefit rulers that supported them and their kingdoms. Where kings blew their own trumpets in the inscriptions composed on their behalf, the Brahmins used the literature for which they were responsible to exalt the concentration of religious energy in what they called âśramas, depicted as places of great peace and intense religious activity. ${ }^{197}$ The literature for which Brahmins were responsible is, of

\footnotetext{
${ }^{196}$ Datta, 1989: 84 f.; 92.

${ }^{197}$ Cp. Malamoud, 2005: 173: “Le 'bois d'ascétisme' est, dans l'Inde, la forme simple et parfaite de l'Utopie."
} 
course, what we habitually refer to as classical Sanskrit literature, including the Sanskrit epics. ${ }^{198}$

Seen in this way, it is possible to consider that the references to agrahäras which we find mentioned primarily in inscriptions, and those to âsramas which are so frequent in classical Sanskrit literature, concern one and the same historical institution, or better perhaps: two different institutions with considerable overlap. Agrahäras were donated to Brahmins because their donors expected their occupants to live more or less in accordance with life as it was presumably lived in àśramas, and Brahmins depicted āśramas in this particular manner at least in part in order to entice their rulers to create such settlements, or more of them.

This, then, is a hypothesis that is to be tested. Consider the following challenge it has to face. Thapar's formulation "new incipient institution which was to develop into the agrahāras of post-Gupta times" suggests that the forerunners of the agrahäras of post-Gupta times were still a new phenomenon at the time of Kālidāsa, and as yet non-existent at the time of the Sanskrit epics. In other words, it suggests that âśramas existed well before the institution associated with the name agrahäras came about. Is this correct?

An inspection of the available evidence shows that nothing is less certain. We have seen that the Sanskrit epics are among the earliest sources that use the term āśrama to refer to places where ascetically inclined Brahmins reside. Well, the Mahābhärata is also among the earliest sources that use the term agrahāra. ${ }^{199}$ It is used several times in books 3 and 15, at least once in a passage that shows that its meaning corresponds to later usage: Bhīma, the father of Damayantī,

\footnotetext{
${ }^{198}$ Occasionally the voice of a donee finds expression in an inscription. The Śaiva ascetic named Prabodhaśiva, for example, created an āśrama in the second half of the tenth century which is described as follows (R. D. Banerji in EpInd 21 (1931-32), p. 152): "At night, this hermitage (ā́rama) causes to the people the semblance of lightning on account of the phosphorescence of plants (growing near it), resembling lightning, (that) of clouds on account of the (dark) bees flying at the sides of mountain peaks, (that of thunder) on account of roars of lions causing the skies to echo (and that of showers) on account of the air being cooled by the sprays of the waters of the Śnna. In this place herds of monkeys kiss the cubs of lions, the young one of a deer sucks at the breast of the lioness; so other (lower animals), who are (natural) enemies, take leave of their antipathy; indeed, in forests devoted to austerities (tapovana) the minds of all become peaceful." ${ }^{199}$ We have already seen that the Pāli buddhist canon speaks about both āśramas and brahmadeyas. It is possible that these concepts belong to a relatively late layer of the texts; see below.
} 
promises to give as agrahära a village the size of a town to the Brahmin who will find his son-in-law Nala. ${ }^{200}$ Book 15 uses the compound brahmadeyāgrahära. ${ }^{201}$ There is also a section on the donation of land (bhümidāna) in the Anuśāsanaparvan (Mhbh 13.61), which we may legitimately suspect of being more recent. We read here that "nothing is superior to the giving of land" (v. 4) and other laudatory remarks. Donations of land are also mentioned elsewhere in the Mahābhārata, regularly in other sections of the Anuśāsanaparvan, but also in the first book (Mhbh 1.57.26; where it is a source of purification) and in the Śantiparvan (at Mhbh 12.36.16 it is once again a means of purification). According to the Anuśāsanaparvan, "whatever sin a man may commit when in straitened circumstances, he is purified therefrom by making a gift of only as much land as is equal to gocarma". ${ }^{202}$ The Rāmāyana states that the giver of land (bhümida) attains the highest destiny (paramā gati; v. 35), the one also attained by heroes and good people as a result of vedic study (svādhyāya) and asceticism (tapas) (Rām 2.58.37).

Other ancient texts confirm that land grants were known from an early time onward. Several passages in vedic and its auxiliary literature contain references to land grants. ${ }^{203}$ Consider the following passage from the Śatapatha Brāhmaṇa (13.7.1.15; tr. Eggeling): "It was Kaśyapa who officiated in his sacrifice, and it was concerning this that the $\operatorname{Earth}^{204}$ also sang the stanza; — 'No mortal must give me away; thou wast foolish, Viśvakarman Bhauvana: she (the earth) will sink into the midst of the water; vain is this thy promise unto Kaśyapa." Here, then, a land grant is referred to in disapproving terms. The same verse, slightly modified, is again put in the mouth of the earth (bhümi) at Aitareya Brāhmaṇa 39.8 (8.21), once again in connection with Viśvakarman Bhauvana. A passage in the Chāndogya Upanișad (4.2) is less antagonistic to the gift of land. It tells the story of Jānaśruti Pautrāyaṇa, a generous donor who wishes to be

\footnotetext{
${ }^{200}$ Mhbh 3.65.1-3: agrahāram ca dāsyāmi grāmam nagarasammitam. See further Mhbh 3.222.43 (unusually explained by Nīlakantha and van Buitenen).

${ }^{201}$ Mhbh 15.2.2; 15.16.15; 15.19.11.

${ }^{202}$ Kane, HistDh II, 2 p. 859, with a reference to Mhbh 13.61 .16 and other texts.

${ }^{203}$ Cp. Chauhan, 2004: 79; Thaplyal, 2004: 233 ff.

${ }^{204}$ Eggeling explains: "Or, the ground, which Viśvakarman Bhauvana gave away as sacrificial fee".
} 
instructed by a certain Raikva. He offers him "six hundred cows, a gold necklace, and a carriage drawn by a she-mule" (tr. Olivelle), but Raikva is not interested. Only when a wife and the village in which he lives are added to the list does he agree.

[A word should be added about passages in vedic and para-vedic literature that refer to a sacrificer "who desires a village". The expression grāmakāma occurs in various Saṃhitās of the Black Yajurveda (TaitS; MaitS; KāthhS; see VWC I, 2 p. 1266), in a number of Brāhmaṇas (VWC II, 1 p. 613) and Śrautasūtras (VWC IV, 2 p. 1028). Rau (1957: 59) observes that those desirous of a village probably feel entitled that a village be given as a fiefdom to them ("Wo immer unsere Quellen für einen grāmakāma bestimmte Opfer vorschreiben, denken sie wahrscheinlich zunächst an eine Person, die vom König ein Dorf als Lehen zu erhalten sich gerechtigt glaubt”). Bodewitz (1990: 227 n. 2), citing Rau, comments: "This may apply in the case of [the Jaiminīya Brāhmana], where the economic profit is of central importance, but in [the Pañcavimsśa Brāhmana] the leadership of the grāma, to be regarded as a 'Schar wandernder Viehzüchter' (Rau, p. 53) or a clan, seems to be meant." Whatever the historically correct interpretation in each text and context, the frequent occurrence of this term in vedic and para-vedic literature may have contributed in later times to giving a solid foundation to the aspirations of those who wished to become recipients of a village as agrahära. Indeed, the ninth century author Jayanta Bhatta reports that his grandfather, wishing a village, performed the sāmgrahaṇ̄ sacrifice; as a result he obtained the village Gauramūlaka. ${ }^{205}$ ]

Some Dharmasūtras present further material. The Āpastamba Dharmasūtra (2.26.1) stipulates: "If [a king] gives land (kșetra) and wealth to Brahmins according to their worth without depriving his own dependents, he will win eternal worlds." (tr. Olivelle). The Gautama Dharmasūtra (19.16) enumerates land (bhūmi) in a list of gifts: "Gold, cow, garment, horse, land,

\footnotetext{
205 "My own grandfather, desiring a village, performed the sāmgrahaṇi sacrifice. Immediately after the completion of the sacrifice he obtained the village of Gauramūlaka." (tr. Dezsö, as cited in Kataoka, 2007: 314 n. 5.) François Voegeli draws in this connection my attention to TaitS 2.3.9.2: vaiśvadevīn sāmgrahaṇịn nirvaped grāmakāmah. See further Caland, 1908: $106 \mathrm{f}$.
} 
sesame seeds, ghee, and food — these are the gifts." (tr. Olivelle). The Vasiștha Dharmasūtra (28.16) specifies: "A man who gives gifts of gold, land, or cows obtains an eternal reward." (tr. Olivelle). And again (29.19): “Three, they say, are super-gifts: cows, land (prthvi) , and knowledge. The gift of knowledge is superior to all gifts and surpasses even those super-gifts." (tr. Olivelle). The Śāikhāyana (1.14.13-14), Kaușītaka (1.8.33-34) and the Pāraskara Gṛhyasūtras (1.8.15-16) state: "A cow is the optional gift to be given by a Brahmin, a village by a Rājanya ..." (tr. Oldenberg). The Gobhila Grhyasūtra (4.8.14-16) describes an oblation of butter made with the mouth while repeating a certain mantra with the mind, then adds: "If (that oblation of butter) catches fire, twelve villages (will be his). If smoke arises, at least three."206

These passages show that there is no reason to think that agrahäras — or rather the institution of giving land to Brahmins, under whatever name ${ }^{207}$ — are a more recent institution than the āśramas, the "hermitages" where pious Brahmins dedicate themselves to their religious duties. Chronological considerations do not oblige us to abandon the hypothesis that these two expressions refer to related institutions - in some cases one single institution seen from two different angles — rather than to two altogether different ones.

The two different angles can easily be specified. Broadly speaking, the word áśrama is used from the perspective of the Brahmin recipient (or of him who wishes to become a recipient), agrahära from the perspective of the donor, often a royal donor. Prima facie, much pleads in favour of this distinction. The word āśrama is omnipresent in brahmanical literature from a certain date onward, agrahāra is equally omnipresent in inscriptions made on behalf of donors. ${ }^{208}$ Only rarely are these perspectives interchanged, as in Aśvaghoṣa's Buddhacarita 2.12: "And by constructing there gardens, temples, âśramas, wells, water-halls, lotusponds and groves, they showed their devotion to dharma, as if they had seen

\footnotetext{
${ }^{206}$ GobhGS 4.8.15-16: jvalantyām dvādaśa grāmāh/ dhūme tryavarārddhyāh/. Tr. Oldenberg.

${ }^{207}$ Other frequently employed expressions are brahmadeya and brahmadāya. In later sources brahmadeya and agrahära do not always mean quite the same; see Stein, 1980: 145.

${ }^{208}$ Cp. EDS s.v. agrahāra. A number of inscriptions are, inevitably, forgeries; see Salomon, 2009. Texts like the Rājatarangin̄in, which already by its title reveals itself as a history of kings, are exceptions, for obvious reasons.
} 
Paradise before their eyes." (tr. Johnston, modified). Here, exceptionally, āśramas are described as having been provided by donors. In the Sutasoma Jätaka which is chapter 31 of Āryaśūra's Jātakamālā a prince announces to have established (niveśita) hermitages (áśramapada), beside other things. ${ }^{209}$ More typically descriptions of áśramas do not mention donors, or even the fact that they have donors: âśramas are simply there, presumably created by their virtuous inhabitants themselves.

What do inscriptions tell us about the time when land gifts to Brahmins became current? Already the Hāthīgumphā Inscription of King Khāravela of Kalinga, which appears to belong to the middle of the first century BCE, ${ }^{210}$ records that Khāravela gave parihāra to Brahmins (Bamaṇānam jātị̣ parihārạ̣ dadāti; Kant, 1971/2000: 15, tr. p. 28; Jayaswal \& Banerji, 1933: 79, 88). Parihāra ("exemptions"), according to Olivelle (2005: 303 n. 7.201), refers “to tax holidays of varying lengths granted to Brahmins and other significant individuals of $[\ldots]$ conquered lands". Freedom from taxation is one of the principal characteristics of the agrahäras. It seems therefore permissible to assume that already Khāravela, though himself a Jaina, gave agrahāras or similar gifts to Brahmins. [It may be significant that this fact is mentioned in a passage in which Khāravela is recorded to have been close to (to have conquered?) Rājagrha and perhaps Mathurā. This might suggest that Khāravela came in contact with Brahmins in regions to the west of his homeland Kalinga. In other words, the wording of the inscription allows us to consider the possibility that the presence of Brahmins in Kalinga at that time was still feeble or even non-existent.] $]^{211}$

Gifts to Brahmins are also mentioned in the Nānāghāt inscriptions presented and discussed by G. Bühler. ${ }^{212}$ These too may date from the middle of the first century BCE (Ray, 1986: 36 f., 212) and appear to have been ordered by the widowed queen of King Sătakarni. We learn from them that sacrifices had

\footnotetext{
${ }^{209} \mathrm{Jm}$ p. 219 1. 14-15; Jm(V) p. 228 1. 11-12.

${ }^{210}$ Kulke \& Rothermund, 1998: 95. For arguments in support of this date, see Sircar, 1951: 215 f.; see further Dundas, 2006: 392 n. 17. Dates as early as 172 BCE have been proposed, but may have to be abandonded. Cf. Kumar, 1999: 901.

${ }^{211}$ We have seen in the introduction that Aśoka's thirteenth Rock Edict, which states that there are Śramanas and Brahmins everywhere in his kingdom, except among the Greeks, has to be interpreted loosely.

${ }^{212}$ Cp. Lüders, 1912/1973: 121 no. 1112.
} 
been performed and what and how much had been given by way of sacrificial fees to the Brahmins involved. The inscriptions are damaged, but enough remains to see that the remuneration had been generous: numerous cows, coins, waterpots, elephants, and much else. Most interesting for our purposes is the mention of one excellent village (gamavaro) and again one village (gâmo) amongst the things donated. ${ }^{213}$ This means that the first inscriptional sources that enumerate gifts to Brahmins mention, among those gifts, twice the gift of a village. This confirms the idea that donations of land — including villages, i.e., inhabited land — are already part of the remuneration of Brahmins in our earliest surviving relevant inscriptional sources. They are frequent in slightly more recent inscriptions, too. King Nahapāna, for example, gave sixteen villages to gods and Brahmins (devatābhyaḥ brāhmaṇebhyaś ca) according to inscriptions in Nāsik and Karle dating from the first century $\mathrm{CE}^{2}{ }^{214}$

Note in passing that the relationship between land and inhabited villages is close: inhabited villages can provide the manpower to work the land. This is particularly clear from two inscription in Nāsik that concern a gift of land donated by King Sătakarṇi Gautamīputra, dating from around the year 100 CE (Ray, 1986: 38). The first inscription stipulates that a field of 200 nivartanas is given to certain ascetics. The second inscription refers back to the first one and states: "We have formerly given a field in the village of Kakhadī to the ascetics (and) mendicants who live here on the mount Triraśmi in the cave that is our meritorious gift; and that field is not (now) tilled, and that village is no (longer) inhabited." To compensate for this loss, another field is given to the same ascetics and mendicants. ${ }^{215}$ This may be generalized in the sense that the gift of what seems to be mere land may often have implied that people living on or near that

\footnotetext{
${ }^{213}$ Burgess, 1883: 59 ff. The transcript of no. I (10) has gamavaro, that of no. II (1) has gāmo. See also Sircar, 1965: p. 194 1. 10-11 and p. 196 (Sanskrit). Sircar dates this inscription in the second half of the first century BCE. The translation "village" for gāma is used, "not in its strict English sense but, as Baden-Powell used it in his well-known work on land tenure in India, to mean "a group of landholdings aggregated in one place" (Gunawardana, 1979: 55, with a reference to B. H. Baden-Powell, Land Systems of British India, Oxford, 1896, Vol. I, p. 21).

${ }^{214}$ Burgess, 1881: 99-101; Ray, 1986: 38, 212. For a list of such donations, see Ray, 1986: $221 \mathrm{ff}$.

${ }^{215}$ Burgess, 1881: 104 ff.; E. Senart in EpInd 8 (1905-06), 71 ff.
} 
land — in a "village" — were obliged to work on it. ${ }^{216}$ So when another inscription from Nasik states that a field is given to a cave, with the specification that "from this field [accrues] the providing of clothes for the ascetic [living there]", we can be sure that the ascetic living in the cave is not supposed to till the land in order to buy clothes; ${ }^{217}$ it is rather local villagers who are expected to work on the land and put the benefit at the disposal of the ascetic. ${ }^{218}$ An inscription from the middle of the fourth century CE concerns, among other things, a grant of land to a Brahmin, specifying the name of the family-men (kutumbin) by whom the pieces of land are ploughed. ${ }^{219}$ It is in this connection interesting to recall that the Mānava Dharmaśāstra includes the person who lives from agriculture (krșijīvin) in its list of people to be avoided (3.165-66).

Brahmins, we are tempted to conclude from this, should not themselves till the land they have been granted. ${ }^{220}$

This does not mean that no Brahmins ever tilled the soil with their own hands. ${ }^{221}$ An interesting counterexample may be constituted by the Ghugrāhāti copper-plate inscription, presumably dating from the end of the sixth century CE. Its main content is summarized in the following manner.:"222 "Supratīka Svāmī, a Brahmin, approached the District Court [...] and applied for a piece of waste land of that locality for settling himself on it. The Elders and the men of experience decided to give him the piece of land free of any consideration, and after authorising Keśava, Nayanāga and others to mature the transaction on their behalf

\footnotetext{
${ }^{216}$ Compare this with the following remark by Oskar von Hinüber (2007: 186-87): “one of the rules given in the collection of ācāras 'customary law', in an ācārasthitipātra 'a vessel for the continuity of customary law' ..., enumerated in a contract between a king Viṣnuṣeṇa and the merchants at Lohātakagrāma located probably in Gujarat, shows that peasants certainly were not free: no. 24 (line 10 of the inscription) varșāsu svavisayāt bījārttham āgatakakarșakāh svāminā na grāhyāḥ "Those peasants, who came here from their area during the rains to buy seeds, must not be apprehended (and thus prevented from buying) by (their) owner"."

${ }^{217}$ EpInd 8 (1905-06), 77.

${ }^{218}$ On the question whether Brahmins themselves ever cultivated the land that was granted to them, see below.

${ }_{219}^{19}$ D. B. Diskalkar in EpInd 21 (1931-32), p. 181.

${ }^{220}$ The circumstance that there are books in Sanskrit on agriculture (krsisiśastra) shows that Brahmins were interested in agriculture, but does not by itself constitute compelling evidence that they practised it with their own hands; see Wojtilla, 2006.

${ }^{221}$ See Ritschl, 1980; Gupta, 1983: 40 f.; Njammasch, 2001: 298 f.; Virkus, 2004: 44 f.

${ }^{222}$ Nalinikanta Bhattasali in EpInd 18 (1925-26), p. 75-76.
} 
gave the piece of land to Supratīka Svāmī. The transaction was ratified by the District Court by the issue of a copper-plate deed." Supratīka Svāmī wants this land, the inscription specifies, "for the establishment of bali, caru and sattra, (thus) getting it to be of use to a Brahmin”. The Elders and others gave it to him on the basis of the following consideration: "The land, which is full of pits and which is infested with wild beasts, is unprofitable to the king both as regards revenue and religious merit (dharmārthanisphalā). That land, if made capable of being used, does bring revenue and merit (arthadharmakrt) to the king himself." 223 Here one gains the impression that the donee himself is going to work on the land. It is perhaps significant that this donation is not called agrahāra or brahmadeya in the inscription and that it is not exempted from taxes (the king is going to derive revenue from it). The very fact that the donee is recorded to have asked for it is remarkable and rare. ${ }^{224}$

Often the donation of a village is presented as follows: the taxes and other income that the king would customarily receive from that village should now be handed over to the donee. This is sometimes explicitly stated, as in a Gupta copper plate inscription from 493-94, which records the gift of a village to a Brahmin; the inhabitants of the village receive the following command: "You yourselves shall render to him (i.e., to the Brahmin) the offering of the tribute of the customary royalties and taxes, and shall be obedient to [his] commands."225 Another copper plate inscription, some twenty years later, adds "gold etc." to the items to be rendered to the donees. 226

\footnotetext{
${ }^{223}$ Most frequently, "land-grants are not made in the intention to increase the agricultural area, but, as stated in the documents, to make merit. Then often fields already under cultivation are donated, and not khila land. [...], seen in the proper perspective in time and space, perhaps hardly any ruler contributed substantially to the enlargement of land under cultivation." (Hinüber, 2007: 192 n. 38). Vijay Nath's (2001: 23) opinion, according to which "reclamation of virgin tracts was a primary purpose of such gifts of land, at least during the initial phase", must therefore be treated with caution.

${ }^{224}$ A fifteenth century copper-plate inscription records that a certain Vīranārya, apparently a Brahmin, asked for a village in the following words: "Oh! King Virūpākșa! grant us the village situated there named Somalāpura." It appears that this Vīranāârya subsequently distributed it among Brahmins. See K. V. Subrahmanya Aiyar in EpInd 17 (1923-24), pp. 193-204.

${ }^{225}$ Fleet, 1887 (CII 3), pp. 117-120.

${ }^{226}$ Fleet, 1887 (CII 3), pp. 125-129.
} 
The gift of a village may also cover cases where a village that is largely or even exclusively inhabited by Brahmins is freed from all taxes. The parihära given by King Khāravela of Kalinga to Brahmins (see above) may be of this nature. There are reasons to believe that Brahmins often clustered together in villages. Passages belonging to the earliest layers of the buddhist canon use the expression brāhmana-gāma to refer to them. ${ }^{227}$ However, a Brahmin village (brāhmaṇa-gāma) is not to be confused with a brahmadeyya, and it is not impossible that this latter concept did not find its way into the buddhist canon until later. The introduction of the Ambattha Sutta shows the difference between the two. ${ }^{228}$ It speaks of the Brahmin village called Icchānankala, where the Buddha is visited by Ambatțha. Ambattha lives somewhere else, viz., in a place called Ukkattha which is a brahmadeyya, a royal gift (rājadāya) given by King Pasenadi of Kosala. Apparently the Brahmin village Icchānankala is not itself a royal gift, a brahmadeyya. ${ }^{229}$ The introduction to the Kütadanta Sutta, on the other hand, shows that a Brahmin village can be a royal gift and a brahmadeyya, for the village Khānumata is here described both ways. ${ }^{230}$

Our reflections so far have led us to the following. There are good reasons to think that the āsramas which we find so often depicted in brahmanical literature correspond to an idealized vision as to what brahmanical settlements looked like or should look like. Their idealized depiction also had political purposes, among them to induce kings and those around them to grant land to Brahmins. These idealized depictions could fulfil this aim if they convinced those in power that by creating such settlements they could harness brahmanical power and use it for their own benefit. The long-term success of this brahmanical initiative was great. We have already seen that agrahāras changed the socio-economic landscape in post-Gupta times. But the initiative to try to induce rulers to part with land (or rather, the benefits to be derived from it) had been taken many centuries earlier;

\footnotetext{
${ }^{227}$ See Hinüber, 2008a.

${ }^{228}$ On the relatively late date of the Ambattha Sutta, see Bronkhorst, 2007: $353 \mathrm{ff}$. (Appendix VI).

${ }^{229}$ DN I p. 87.

${ }^{230}$ DN I p. 127.
} 
the Sanskrit epics contain perhaps the earliest expressions of the ideal of the $\bar{a}$ śrama, i.e., the ideal which induced rulers to part with land in favour of Brahmins. Let us look at a concrete example.

The Rāmāyana tells us that Rāma, Lakṣmaṇa and Sītā come to the âśrama of the muni Bharadvāja, situated at or near the confluence of the Gangā and the Yamunā. ${ }^{231}$ Bharadvāja is described as being surrounded by deer, birds and munis (Rām 2.48.17: mrgapakșibhir āsīno munibhiś ca samantatah), no doubt an indication of the peaceful treatment accorded also to animals. Bharadvāja is further said to have performed the Agnihotra (v. 11: hutägnihotra), as we might expect from the chief inhabitant of an ásrama. However, we then learn that there are people from town and countryside nearby (v. 22: ita āsannah paurajānapado janaḥ) who might come and disturb the áśrama out of curiosity to see Rāma and his companions. To preserve the peace, Rāma decides to stay somewhere else, along with his brother and wife.

So far there is little in the description that might make us suspect the great powers that are associated with the chief inhabitant of the āśrama, Bharadvāja. This becomes clear later on in the story (Rām 2.84 ff.). Bharata is determined to find Rāma, his older brother, in the hope of taking him back to the capital so as to accept kingship. Bharata, too, arrives at Bharadvāja's āśrama, but unlike Rāma he is accompanied by a large army. Knowing how to behave, he leaves the army behind when approaching the āśrama, takes off his arms, and enters alone with his ministers. Bharadvāja is, once again, hospitable, and insists on offering hospitality to the whole army, in spite of protestations by Bharata. In order to do so, he invokes a number of gods and other supernatural beings, and the result is amazing. The soldiers receive their best meal ever, including meat and alcoholic beverages, but not only that. There are pleasures for all the senses, including music and, perhaps more importantly, beautiful damsels, fifteen for each man. Not surprisingly, the soldiers have the time of their lives, and express their intention never to return to the capital, nor to move on, saying: "This is heaven."

It is not necessary to dwell on the delights which Bharata, his officers and

\footnotetext{
${ }^{231}$ See further Pieruccini, 2009. Bharadvāja's āśrama may be depicted in a sculpture at Bharhut; see Mookerji, 1947: illustration facing p. 344.
} 
soldiers receive, for the duration of one night, in the āśrama of Bharadvāja. It is clear to everyone, including Bharata's own soldiers, that this is better than anything they can expect from the king. It also shows that this humble Brahmin in his âśrama can compete, if he so wishes, with anything the king might have on offer, and will win this competition hands down. Bharadvāja, by being a religious Brahmin, disposes of unsuspected powers, and the king, any king, is well advised to stay on good terms with him. What is more, by encouraging outstanding Brahmins to dedicate themselves to religious practices in appropriate surroundings — read: âśramas — a king creates a spiritual powerhouse that can supplement his own worldly powers.

For the Mahābhärata we can refer to Monika Shee's study of tapas and tapasvin in the narrative portions of this epic (1986). Shee dedicates several pages (305-315) to the characteristics of áśramas. She emphasizes their idyllic nature, and the double perfection found in them: the perfection of nature in the âsramas, and the perfection of its inhabitants. This double perfection, and the sacredness of the place in general, may account for the fact that here wild animals are no threat to each other, that there are flowers around the year, and that beauty and loveliness characterize the áśrama throughout. The Mahābhārata leaves no doubt as to the fearful power of ascetically inclined Brahmins. It is not surprising that kings could be persuaded that the peace of the ásrama makes it the safest place for these potentially terrifying beings to live in. One passage adds that there are no āśramas during the evil times at the end of the Yuga. ${ }^{232}$

The power of Brahmins, and the care kings should take not to offend them, is a theme that occurs also in later texts. ${ }^{233}$ The following passage from the Mānava Dharmaśāstra says it all:234

\footnotetext{
${ }^{232}$ Mhbh 3.186.43: āśramā ... na bhavanti yugakșaye.

${ }^{233}$ A useful collection of passages dealing with the Brahmins' "weapons of virtue", both in the epics and in more recent literature, is provided by Minoru Hara (2007: 613-618).

${ }^{234}$ Manu 9.313-316: parām apy āpadam prāpto brāhmaṇān na prakopayet/ te hy enam kupitā hanyuh sadyah sabalavāhanam// yaih krtạ̣ sarvabhakșo 'gnir apeyaś ca mahodadhiḥ/ kṣaȳ cāpyāyitaś cenduḥ ko na naśyet prakopya tān// lokān anyān sṛjeyur ye lokapālāmśs ca kopitāh/ devān kuryur adevāṃś ca kah kṣinvams tān samrdhnuyāt// yān samāsritya tiș̣thanti lokā devāś ca sarvadā/ brahma caiva dhanam yeșām ko himsyāt tāã jijivișuhl/. Tr. Olivelle.
} 
Even in the face of the deepest adversity, he must never anger Brahmins; for when they are angered, they will destroy him instantly along with his army and conveyances. They made the fire a consumer of everything, the ocean undrinkable, and the moon to wane and wax - who would not be destroyed when he angers these? When angered, they could create other worlds and other guardians of the world, they could convert gods into nongods - who would prosper when he injures these? The worlds and the gods always exist by taking refuge in them, and their wealth is the Veda who would injure them if he wishes to live?

Indeed, when it comes to it, the Brahmin does not need the king: ${ }^{235}$

\begin{abstract}
A Brahmin who knows the Law shall not inform the king about any matter; solely with his own power should he chastise men who do him harm. Between the king's power and his own, his own power is far more potent. A twice-born, therefore, should punish enemies solely with his own power, and make use of vedic texts of Atharva-Ängirasa - that is indisputable. Clearly, speech is the Brahmin's weapon; with that a twiceborn should strike down his enemies.
\end{abstract}

Where did the idea of brahmanical âsramas come from? If the theory here presented as to the link between âśramas and land grants is accepted, at least a partial answer to this question may be found. The vedic Brahmins were not the only ones to receive land grants in early India nor, it would seem, the first ones. The very fact that the presumably oldest references to the giving of land in vedic literature are, as we have seen, critical of this practice suggests that the practice existed outside its milieu and was frowned upon. ${ }^{236}$ We have seen in the introduction that according to the buddhist textual tradition, Anāthapiṇ̣ika put a park in Śrāvastī called Jetavana at the disposal of the Buddha, and that King Bimbisāra presented the park called Venuvana to him and to the community of monks. It is more than likely that these stories from the Vinaya do not date back to the time of the Buddha, but they may be relatively old. The earliest gift of an immovable object recorded in an inscription is the donation of a cave to the

\footnotetext{
${ }^{235}$ Manu 11.31-33: na brāhmaṇo vedayīta kimcid rājani dharmavit/ svavīryenaiva tā̃n chișyān mānavān apakārinah// svavīryād rājavīryāc ca svavīryạ̣ balavattaram/ tasmāat svenaiva vīryeṇa nigrhnn̄yād arīn dvijah// śrutīr atharvāngirasīh kuryād ity avicāritam/ vāk śastrạ̣ vai brāhmanasya tena hanyād arīn dvijahl/. Tr. Olivelle.

${ }^{236}$ Śabara's Mìmāmsā Bhāsya still maintains that land cannot be given away, only the share of its produce that the "owner" may be entitled to; Kane II, 2, p. 865-66.
} 
Ājīivikas by emperor Aśoka. ${ }^{237}$ Another inscription of Aśoka declares the village Lummini, where the Buddha was born, free of taxes; ${ }^{238}$ this is what might be called a donation of a village, even if the donees in this particular case appear to be the inhabitants of the village itself.

It seems, then, that the Brahmins of the centuries preceding the Common Era had to compete for favours from the rich and powerful. One of the areas in which this competition found expression was the suitability to receive presents, including presents of land and villages. The Buddhists, Jainas and Ājīivikas were obvious and rewarding recipients for such generosity, for they needed shelter for their monks, whether in the form of caves or in some other form. ${ }^{239}$ Note that a shelter by itself is of limited use, for its inhabitants have to eat. The gifts of caves (or of other forms of shelter) could therefore be accompanied by the gift of land (including people to work it), or of one or more villages. An inscription from Karle indicates, as a matter of fact, that the son-in-law of King Nahapāna, whom we encountered earlier and situated in the first century $\mathrm{CE}$, gave a village "for the support of the ascetics living in the caves at Valūraka (= Karle) without any distinction of sect or origin, for all who would keep the varșa (there). ${ }^{, 240}$ Various other gifts of villages for the inhabitants of caves are recorded in inscriptions from the same area and approximately the same time. A cave inscription from Nasik, for example, concerns the gift of the cave and "grants to this meritorious donation (viz., the cave) the village Pisājipadaka". ${ }^{241}$ The Brahmins were at a disadvantage in this respect, unless they too created - at least in name, perhaps also in reality - communities of ascetics dedicated to the religious life, brahmanical fashion. The āśrama (whether only literary fiction or real) appears to

\footnotetext{
${ }^{237}$ Bloch, 1950: 156.

${ }^{238}$ Bloch, 1950: 157; G. Bühler in EpInd 5 (1898-99), 4 ff.

${ }^{239}$ Cp. Lubin, 2005: 80: "Ritualist Brahmins do not appear to have established monastic or scholarly centers comparable to those of the Buddhists. What institutions did Brahmin priests and scholars develop that allowed them to carry on and eventually to attain equal success in many of the domains where Buddhism was successful?" Part of the answer to this question may well be: āśramas / agrahāras. An inscription from Nālandā mentions the expression agrahāra where one should perhaps have expected vihära; see Sastri, 1942: 83. On the idyllic side of buddhist monasteries, see Schopen, 2006a. The combination āśrama-vihāra, too, occurs in inscriptions; see note 242, below.

${ }^{240}$ E. Senart in EpInd 7 (1902-03), 57 ff.

${ }^{241}$ E. Senart in EpInd 8 (1905-06), 59-65.
} 
have been their response. ${ }^{242}$

Timothy Lubin states, in a recent article (2005: 82): "Brahmins did gather to meet in assemblies called parișad, samsad, or sabha to decide questions of ritual or social dharma, and to serve as a local court of law. But the development of durable, large-scale brahmanical institutions lagged behind that of buddhist monasteries. When it came, it took the form of brahmin settlements on endowed, tax-free lands (agrahāras) and royally sponsored temples." At the conclusion of this chapter we may think that, if brahmanical institutions lagged behind, this was not for lack of trying.

\footnotetext{
${ }^{242}$ The existence, many centuries later, of a buddhist monasteryin East Bengal called āśrama-vihāra (Barua, 1969: 179) suggests that the Buddhists were well aware of the parallelism of the two institutions. The same expression āśrama-vihāra to refer to a buddhist monastery is attested in an inscription from the Gupta period; see Chatterjee, 1999: 239-40; Chakraborti, 1978: 31.
} 


\section{BUDDHISM CONFRONTED WITH BRAHMANISM}

\section{III.1 A courtly challenge}

The preceding chapters have shown that the revised form of Brahmanism that had come to the fore during and especially after the Maurya empire was quickly becoming a major competitor for royal support. In this competition the Brahmins had several advantages which the Buddhists had not. The Brahmins, for example, had always been involved in affairs of state, and were therefore well prepared to take on tasks such as counselling the king. The Brahmins, moreover, had clear ideas about society, how it should be and how it could and should be governed. They could advise and encourage the king in his political ambitions, and did not hesitate to justify his military ventures if that seemed fruitful. The Buddhists, if they wanted to be heard at court, had to be able to give some sensible advice, too. They had to develop some ideas as to what society should be like and how it should be governed. They had to have notions about war and peace, and other issues related to statecraft. ${ }^{243}$

The Buddhists were aware of all this, and had been aware of it from an early date onward. Already some ancient discourses address these questions. The challenge was however daunting. Buddhist thinkers were not and could not be as pragmatic as their brahmanical confreres. Unlike Brahmanism, Buddhism did not start out as a vision of society, even less as a model for governing a state. It taught a path to escape from rebirth, and following this path implied leaving society. The nature of the society left behind was of little concern to those who decided to follow the teaching of the Buddha. ${ }^{244}$

This initial situation did not last long. Buddhism soon became the victim of its own success. The community of monks and nuns organized itself, and monasteries were created. ${ }^{245}$ Questions regarding the interaction between the buddhist community and society at large became inevitable. In order to build

\footnotetext{
${ }^{243}$ Cp. Faure, 2008: $51 \mathrm{ff}$.

${ }^{244}$ In his contacts with contemporary kings, the Buddha abstained from giving them political advice, if the early sources are to be trusted; Bareau, 1993: 38.

${ }^{245}$ See note 25 , above.
} 
monasteries and places of worship, a steady stream of gifts from donors was necessary. ${ }^{246}$ The Buddhists could not for ever go on hiding their heads in the sand as far as questions of society and its political organization were concerned. But the challenge they had to face was, as said above, daunting.

Consider first a discourse in the ancient buddhist canon that deals with the organization of society and explains how it came to be what it is. This text, the Aggañña Sutta, criticizes the brahmanical vision of society and rejects the notion according to which Brahmins are fundamentally different from all other members of society. In this discourse a Brahmin justifies his belief in the pre-eminence of his caste-class with the help of a myth which recounts that Brahmins were born from the mouth of the Creator God. The Aggañña Sutta does not accept this myth, and presents a creation story of its own. In this alternative story, differences between people came about as a result of differences of behaviour in some unspecified past. Brahmins, for example, are the descendants of people who meditated or compiled books. They yet have a common ancestry with all other caste-classes of society. The kingly caste-class came about when people chose one from among themselves to impose order on society. Once again the text emphasizes the common origin of the king with the other caste-classes. ${ }^{247}$

The Aggañ̃̃a Sutta, while criticizing brahmanical ideas, yet adopts some of them. It criticizes the notion that there is a fundamental difference between the four caste-classes of society as taught by the Brahmins, yet accepts this division as being social reality. It also accepts without discussion that kings behave the way they do. In the words of the Aggañña Sutta, a king is a being who, appointed by the rest of the population, "would show anger where anger was due, censure those who deserved it, and banish those who deserved banishment" (tr. p. 413). No further guidelines are provided.

Yet this is where the shoe pinches. Buddhism teaches a path that leads to liberation. This path is open to all human beings, not just Brahmins or certain others. Buddhism is therefore bound to encourage behaviour that, in the long or short run, leads to that goal. The strong arm tactics that worldly rulers use (and

\footnotetext{
${ }^{246}$ For a discussion of gifts to buddhist monasteries in Gujarat, and of the economic position of such monasteries in North India in general, see Njammasch, 2001: $199 \mathrm{f}$. ${ }^{247}$ Cp. Meisig, 1988: $142 \mathrm{f}$.
} 
may be compelled to use) do not lead in that direction. Quite on the contrary, they do the opposite. The Brahmins could maintain that a certain class of people, the warriors, were born with the obligation to use violence in appropriate circumstances, that violence is the svadharma, the correct behaviour of members of that class of society. They could point out that a warrior who does not use violence in such circumstances might expect to be punished for this omission, in this or a next life. For Buddhists this was harder to maintain. They recognized no separate class of warriors, fundamentally different from other human beings, with different obligations and different fates. For Buddhists there was no fundamental difference between a monk and a warrior. If violence was wrong for one, it was wrong for the other.

An edifying story (nr. 46) from Kumāralāta's Kalpanāmaṇịitikā Drsștāntapankkti (perhaps first half of the fourth century CE) ${ }^{248}$ illustrates this. It is about an outcast (candāla) who refuses to execute a criminal, even against the order of the king. The king is furious and kills off most of the family members of our poor outcast, until he understands his mistake. ${ }^{249}$ The story shows that it is wrong to kill a criminal. It is implied that, if it is wrong for an outcast to execute a criminal, it is also wrong for a king to order his execution.

This, then, is the conundrum in which buddhist theoreticians of political power found themselves. Was there a right way of ruling a country, preferably without violence? To cite Bruce Lincoln (2007: xi): "When would-be imperialists come to regard [military conquest, political domination, cultural encompassment, and economic extraction] — and the violence that goes with them - as religiously wrong or morally repugnant, the likelihood that they will realize their ambitions is, thereby, greatly diminished." Or can these goals be attained without violence?

In answering this question the memory of the Maurya empire, and especially of its emperor Aśoka, appears to have made itself felt. There was, on the one hand, the legend of King Aśoka, preserved in buddhist texts in various

\footnotetext{
${ }^{248}$ De Jong, 1988: 429.

${ }^{249}$ Huber, 1908: 216 ff.
} 
languages. ${ }^{250}$ However, Cristina Scherrer-Schaub (2007: 762 n. 14) may well be right in saying that the memory of the "epigraphical" Aśoka survived him for a number of centuries. ${ }^{251}$ Aśoka, as we have seen, talked about the victory of Dharma, i.e. of "righteous rule, correct behaviour". The notion of Dharma in connection with political power had great appeal to the Buddhists. They thought and spoke about a Dharma-king, who conquered the world in an unobjectionable manner. The Cakkavatti-Sïhanāda Sutta, another canonical text, describes what happened to one such righteous king. One day a Wheel appeared to him: ${ }^{252}$

Then, rising from his seat, covering one shoulder with his robe, the king took a gold vessel in his left hand, sprinkled the Wheel with his right hand, and said: "May the noble Wheel-Treasure turn, may the noble WheelTreasure conquer!" The Wheel turned to the east, and the king followed it with his fourfold army. And in whatever country the Wheel stopped, the king took up residence with his fourfold army. And those who opposed him in the eastern region came and said: "Come, Your Majesty, welcome! We are yours, Your Majesty. Rule us, Your Majesty.” And the king said: "Do not take life. Do not take what is not given. Do not commit sexual misconduct. Do not tell lies. Do not drink strong drink. Be moderate in eating." And those who had opposed him in the eastern region became his subjects.

\footnotetext{
${ }^{250}$ See Strong, 1983.

${ }^{251}$ The fact that both Rudradāman (ca. 150 CE) and Samudragupta (two centuries later) left inscriptions in places where there were already inscriptions of Aśoka (Falk, 2006: 118 f.; 158 f.) may be understood as supporting this belief (cf. Hinüber, 2008a: 194-195). Far from being "curieux" and "peu digne d'un grand souverain" (Fussman, 2007: 707), is it not possible that these rulers thus augmented their glory through association with the great former emperor? Note Strong's (1983: 6 f.) observation to the extent that the testimonies of Xuanzang ( $7^{\text {th }}$ century) and Faxian (around $400 \mathrm{CE}$ ), show that there were traditions of interpretation of certain Aśokan edicts, which were however incorrect because no one could read the script any longer. Salomon (2009a: 48) assumes that in Rudradāman's time the Aśokan inscriptions were still at least partially legible and comprehensible, but provides no proof. References back to Maurya times also occur elsewhere (Falk, 2005: 348 f.).

${ }^{252}$ DN III p. $62 \mathrm{f}$;; tr. Walshe, 1987: $397 \mathrm{f}$. For the parallel in Chinese translation, see Warder, 1980: 165 f. Gombrich (1988: 83-84) says the following about this Sūtra: "At the end of the sermon we meet the next Buddha, Metteyya. Since he occurs in no other sermon, this casts doubt on the sermon's authenticity. Another suspicious feature is that the myth is set in an inappropriate frame. Most of the Buddha's sermons are presented as preached in answer to a question or in some other appropriate context; but this one has a beginning and an ending in which the Buddha is talking to monks about something totally different. Either the whole text is apocryphal or at least it has been tampered with. The Theravādin tradition itself, however, does not doubt that the text is authentic ..."
} 
Then the Wheel turned south, west, and north ... (as before). Then the Wheel-Treasure, having conquered the lands from sea to sea, returned to the royal capital and stopped before the king's palace $[\ldots] .{ }^{253}$

We do not know how many buddhist monarchs waited in vain for a WheelTreasure to appear and help them in the task of conquering the world. Without it the task was a lot less enviable, and would inevitably breach the rules that the king was supposed to promulgate, especially those concerning the taking of life and of what is not given. There were, to be sure, always volunteers willing to try to conquer the world even without a Wheel-Treasure. However, what practical advice could their buddhist counsellors give them?

The answer is: very little. ${ }^{254} \mathrm{We}$ are in the possession of some works whose stated aim is to give advice to (sometimes identifiable) kings. One of these is a letter sent to the young King Kaniṣka by the buddhist scholar Mātṛceṭa in the second or third century CE. It is not clear to which Kaniska the letter was addressed (several kings bore that name), nor indeed whether it was really sent to a king of that name. ${ }^{255}$ However, the most famous Kaniṣka (Kaniṣka I) was a king of the Kuṣāna dynasty, ${ }^{256}$ about whom the Indian historian Romila Thapar writes the following (2002: 221): "The Kushana dynasty was in the ascendant in central Asia under Kanishka, whose relationship to the earlier kings has been confirmed by the recent discovery of an inscription in Afghanistan. In this he claims that he conquered hindo/India, i.e., the better-known northwest of India, and proclaimed his conquest in all the cities as far as Champa (in the middle Ganges Plain).” Perhaps the most striking feature of Mātrceța's letter, addressed as it is to the successor and descendent of a king known for his conquests (if not to that king

\footnotetext{
${ }^{253}$ The word cakravartin (Pāli cakkavatti) can mean "being situated in a wheel" as well as "who sets rolling the wheel (of his dominion), turner of the wheel". Gonda (1969: $123 \mathrm{f}$.) thinks that the former may have been its original meaning. The present extract from the Cakkavatti-Sìhanāda Sutta, among the earliest sources that use the term, suggests the opposite. This does not change the fact that this same term may have come to be interpreted in the first of these two senses in later times.

${ }^{254}$ It is certainly no coincidence that J. Gonda's Ancient Indian Kingship from the Religious Point of View (1969) draws almost exclusively on brahmanical sources. ${ }^{255}$ Hartmann, 1987: 36 f.

${ }^{256}$ The beginning of Kaniska's realm appears to have been 127 CE; Falk, 2001. See also Golzio, 2008.
} 
himself), is its emphasis on saving the life of animals. ${ }^{257}$ Nothing at all is said about the killing of humans. ${ }^{258}$

Nāgārjuna was more or less a contemporary of Mātṛceța. ${ }^{259}$ The Precious Garland (Ratnāvalī) attributed to him ${ }^{260}$ contains advice for kings. ${ }^{261}$ Some of the passages involved show that Nāgārjuna's political ideas were still very close to those which we found in the canonical texts mentioned above. Consider the following verse (p. 118): “Through proper honouring of stūpas, honorable beings, Superiors, and the elderly, you will become a Universal Monarch, your glorious hands and feet marked with [a design of] wheels." A Universal Monarch is the same as a Dharma-king, mentioned earlier. Like the Dharma-king, the Universal Monarch is associated with wheels, with this difference that this time wheels appear as marks in his hands. Universal kingdom, here as there, is presented as the outcome of merit. Violent conquest, the verse suggests, can be avoided. ${ }^{262}$

Other passages from the Precious Garland are no more practical, even though the pious and virtuous intentions of its author cannot be doubted. No one would be averse to living in a country ruled by Nāgārjuna's ideal king. ${ }^{263}$ Whether

\footnotetext{
${ }^{257}$ Hahn, 1999: $38 \mathrm{f}$.

${ }^{258}$ This would be a case of "compartmentalization of values", for which Schmithausen (1999: 53 f.) gives some canonical and further non-canonical examples.

${ }^{259}$ Mātrceța was the intellectual "grandchild" of Nāgārjuna according to Bu ston and Tāranātha, but the value of this testimony is dubious; Hartmann, 1987: 36. On

Nāgārjuna's date (probably second century CE), see Walser, 2002.

${ }^{260}$ There is no agreement among modern scholars about this attribution; see Sanderson, 2009: 103 n. 217.

${ }^{261}$ See further Pāsādika, 2001; also 1996.

${ }^{262}$ Perhaps inevitably, Buddhists had a tendency to believe that kings whose memories they cherished had attained power in this ideal manner. The Chinese pilgrim Xuanzang tells the story that King Harsavardhana had invoked the help of the Bodhisattva Avalokiteśvara before ascending the throne. The Bodhisattva had answered: "In your previous life you were a forest-dwelling bhikșu in this wood and practiced the Way diligently. By the power of this meritorious action, you are now a prince in this life. ... With a mind of great compassion, and having sympathy for the people, you will soon become king of all the five parts of India." (Li Rongxi, 1996: 143; cp. Hazra, 1995: 89). The Abhidharma-vibhāșā-śăstra, a buddhist text from the early centuries CE, describes a certain ceremony that is held every five years (the pañcavārșika) as follows: "and the distribution of drink and food to many people is said to have been held in order to cause the fulfilment of the donor's vow to become a cakravartinrāja." (Klimburg-Salter, 1989: 124).

${ }^{263}$ Scherrer-Schaub (2003: 132; cited 2007: 768 f.) draws the following conclusion from Nāgārjuna's advice: "La Ratnāvalī peint une société opulente vivant à une époque très prospère. Le fait que Nāgārjuna exhorte le Roi aux oeuvres d'utilité publique et de
} 
such a king would remain in charge for long is a different question. It seems that even Nāgārjuna himself had some doubts, for he ends his political advice with the following verse (p. 148): "However, if from the unrighteousness of the world it is difficult to rule religiously, then it is right for you to become a monastic for the sake of practice and grandeur." In other words, trying to be a good and virtuous king may turn out to be impossible. In that case the Buddhists have no further advice to offer, except that it is time to turn one's back to the world and become a monk.

The Letter to King Gautamīputra, attributed to the same Nāgārjuna, is even less practical in its advice and even more insistent that a king really finds himself in the wrong place (p. 14): "[In choosing] between the one who conquers [attachment to] the ever unsteady and momentary objects of the six sense-organs and the one who conquers the enemy's army in battle, the wise know the first to be a far greater hero." The advice it gives is, as the text itself admits, more suitable to monks than to kings (p. 65): "It is difficult even for a monk in isolation to follow the counsel which has been given to you; [yet] make this life meaningful through cultivating the quality of the essence of any of these practices."

Another buddhist author belonging roughly to the same time is Âryadeva, who wrote critically about kings in the fourth chapter of his Catuhśataka. ${ }^{264}$ Candrakīrti, in his commentary on this work, presents in no uncertain terms the unwholesome after-effects of kingship:

It is just as if in order to perform a buffalo sacrifice somebody would kill [the animal] and many would eat [its meat], and this evil, however, would only appertain to the killer; in the same way, for the sake of the kingdom,

charité (hôpitaux, lazarets, hospices pour les animaux, points d'eau etc.), qu'il recommande l'institution d'écoles pour l'enseignement de l'écriture, l'enseignement gratuit aux indigents ..., le partage de la nourriture, la libre circulation des biens et la distribution des richesses, accuse une société riche, adonnée aux dépenses somptuaires ..." This conclusion does not seem compelling to me. Is it not easier to conclude that Nāgārjuna had but hazy notions of economics?

${ }^{264}$ See Lang, 1986: 46 f.; 1992. In a private communication, Karen Lang draws attention to the fact that verse 6.6 "seems to refer to castes/classes having their own work/duties [svadharma?] and the idea of the king getting demerit (apunya) from his subjects who fail to do their work properly". 
the king performs [protective] acts of evil and many enjoy the wealth [resulting from it], but the evil he performed, which has terrible fruits [leading] to bad existences, pertains alone to the king. ${ }^{265}$

The story of the prince Temīya, told in a Pāli Jātaka, carries the same message. Prince Temīya knows and remembers from earlier lives that the throne of a king can only lead to hell; he therefore decides to act as if he were lame, deaf and dumb, with the sole purpose of escaping the royal duty awaiting him, even at the expense of being put to death. ${ }^{266}$

A passage from the Questions of King Milinda gives another twist to the dilemma, in such a manner that the punishing king is free of all guilt. Here are some extracts (Rhys Davids, 1890: 254-257):

"Venerable Nāgasena, the Blessed One said: 'Doing no injury to any one, Dwell full of love and kindness in the world.' And on the other hand, he said: 'Punish him who deserves punishment, favour him who is worthy of favour.' Now punishment, Nāgasena, means the cutting off of hands or feet, flogging, casting into bonds, torture, degradation in rank. Such a saying is therefore not worthy of the Blessed One, and he ought not to have made use of it. ..."

"Whosoever, great king, may be put to death, he does not suffer execution by reason of the opinion set forth by the Tathāgatas. He suffers by reason of what he himself has done. But notwithstanding that the doctrine of the Dhamma has been taught (by the Buddhas), would it be possible, great king, for a man who had done nothing wrong, and was walking innocently along the streets, to be seized and put to death by any wise person?" "Certainly not." ...

"Just so, great king, since the thief is not put to death through the word of the Tathāgata, but only through his own act, how can any fault be rightly found on that account with the Teacher?"

It follows that no fault can be attributed to the Buddha, nor, we may add, to the king who orders these punishments. The king is no more than the instrument through which karmic retribution takes place.

\footnotetext{
${ }^{265}$ Zimmermann, 2006: 220.

${ }^{266}$ Zimmermann, 2006: 218 f., with a reference to the Mügapakkha Jätaka (no. 538).
} 
It is conceivable, though not certain, that Mātrceța and Nāgārjuna had read Aśvaghoṣa's Life of the Buddha (Buddhacarita). ${ }^{267}$ Aśvaghoṣa puts the following assessment of kingship in the mouth of the future Buddha after he has left home but before he has reached enlightenment: ${ }^{268}$ "In what way could it be right for a wise man to take sovereignty on himself? It is the abode of delusion in which are to be found fearfulness, the intoxication of pride, weariness and loss of Dharma by the mishandling of others. For kingship is at the same time full of delights and the vehicle of calamity, like a golden palace all on fire, like dainty food mixed with poison, or like a lotus-pond infected with crocodiles. ... For it is better to eat herbs in the forest, embracing the highest contentment as if one were concealing a jewel, than to live with the dangers to which sovereignty is exposed, as if with loathsome black snakes." We may assume that Aśvaghoṣa, one of the very early buddhist authors to compose works in Sanskrit, addressed a courtly audience, as did Mātṛceța and Nāgārjuna. ${ }^{269}$ The topic he is dealing with in his poem allows him to be even more outspoken than the other two, and he does not mince his words.

To conclude this discussion, I will cite one more buddhist text, Vasubandhu's Abhidharmakośa Bhāṣya, which dates from the fourth or fifth century CE. ${ }^{270}$ This text mentions kings, judges (dandanetṛ) and ministers (vyāvahärika) as self-evidently (arthatah) belonging to the group of indisciplined people, along with fishermen, hunters, bandits, executioners, jailors and others. ${ }^{271}$ No comments are necessary.

\footnotetext{
${ }^{267}$ Johnston (1936: II: xiv) provides a piece of evidence, which he does not press, suggesting that Mātrceța is somewhat later in date than Aśvaghoṣa.

${ }^{268}$ Buddhac 9. 40-41, 43.

${ }^{269}$ In the penultimate verse of his Saundarananda (18.63), Aśvaghoṣa states that he composed this poem "with the intention of capturing hearers devoted to other things" (śrot•ṇām grahanāartham anyamanasām). Johnston (1936: II: xxxvii) points out that anyamanas covers both "worldly-minded" and "non-believer".

${ }^{270}$ Saito (2010) proposes a link between, on one hand, the conquest of Purușapura by the Sasanid ruler Sapur I and its subsequent Sasanid occupation from ca. 350 to ca. 410 CE and, on the other, and the fact that Vasubandhu, who was born in Purușapura, left (i.e. presumably fled) this place. This would situate Vasubandhu in that same period, roughly 350-410 CE.

${ }^{271}$ Abhidh-k-bh(P) 4.36, p. 221 1. 13-15; Abhidh-k(VP) vol. 4 p. 91.
} 
Edward Conze wrote, in his book Buddhism, Its Essence and Development (1951: 73), that Buddhism "does not only bring peace of mind to the other-worldly, but it also hands over the world to those who wish to grab it". ${ }^{272}$ I consider this remark overly cynical. I do not deny that there are always plenty of people ready to grab the world when they have a chance. I would however add that those people, even if they are successful (or especially when they are successful), want to think and believe, or want others to think and believe, that their power is somehow justified, that there is an order in which they have a place, preferably at the top. It is easy to see that in this regard Buddhism had less to offer than Brahmanism. Nor could it offer much in matters of practical statecraft and policy. How did the Buddhists deal with this? In order to answer this question I propose a short excursion into a domain which is at first sight unrelated.

Remember Asita. Asita, the "buddhist Simeon", was the Brahmin who predicted the future of the newly born Buddha-to-be: the new-born baby would either become a world-ruler or a Buddha. Asita was a Brahmin, but why? In an earlier chapter we saw that predicting the future was one way in which Brahmins made a living. For our present purposes it is important to note that the Buddhists left these and related occupations to others, i.e., primarily to Brahmins. The result was that Buddhists did not participate in the development of certain sciences in classical India, a phenomenon to be studied in chapter III.2, below.

The Brahmins had one more skill which the Buddhists, it appears, were loath to share. It is the use of formulas and incantations, called mantras in India. The Brahmins derived much of their supernatural power from their knowledge of mantras: the Veda is primarily a collection of mantras. Buddhists could not compete with Brahmins in this respect, and there are indications to show that they did not wish to. By way of example I refer to the first chapter of Kumāralāta's

\footnotetext{
${ }^{272}$ According to Demiéville (1957: 354), "la non-violence bouddhique ... a certainement contribué à affaiblir militairement les peuple lamaïstes, Tibétains et Mongols. Dès le VIII siècle on conseillait à un khan turc de se garder du bouddhisme (et du taoïsme), car, lui disait-on, ces doctrines 'rendent bon et faible et sont, en leur principe, contraires au recours à la guerre et aux conflits de force'; et au XIII ${ }^{\mathrm{e}}$ siècle Khubilai devait se servir du bouddhisme pour neutraliser le Tibet."
} 
Kalpanāmaṇditikā Drṣțāntapañkti, ${ }^{273}$ which recounts a discussion between a buddhist layman and several Brahmins. Told that the Buddha does not pronounce curses after the manner of brahmanical seers, the Brahmins conclude that he has no power, whether for good or bad. In this story the willingness to pronounce curses is clearly depicted as something that characterized Brahmins but not Buddhists. $^{274}$

[It may here in passing be remarked that the Jainas, who had as many and as good reasons for staying away from all forms of prognostication, did not do so. Their Angavijjā "Knowledge of the Parts of the Body", in particular, is a semicanonical text "devoted to the science of prognostication through the observation of external bodily modifications, that is to say "signs". ${ }^{275}$ We will come across further instances that show that Jainism did not succeed quite as well as Buddhism in keeping its distance from the brahmanical tradition.]

It appears, then, that the Buddhists were ready to concede that there were occupations that were best left to Brahmins. These occupations covered all forms of divination and the interpretation of signs. They also covered certain sciences, most notably mathematics and astronomy. To this I propose to add the art of giving professional advice to kings. ${ }^{276}$

This proposition may at first sight look surprising and evoke scepticism. Are there historical examples of Buddhists leaving the task of advising the king to Brahmins even in situations where they were influential enough to take on that task themselves? In the case of physiognomy, astrology, astronomy and mathematics the situation is simple and straightforward: there are brahmanical, but no buddhist treatises in these fields. It is also true that there are no buddhist

\footnotetext{
${ }^{273}$ This work was first thought to be a work of Aśvaghoșa, called Sūtrālaṃkāra; see Hahn, 1982. A French rendering of the Chinese translation is provided in Huber, 1908. ${ }^{274}$ Hahn, 1982: 331; Huber, 1908: $6 \mathrm{f}$.

${ }^{275}$ Dundas, 2006: 403 f. See also Qvarnström, 2002: 112 ff.; 2000: 599 ff.

276 The predominant position of Brahmins at and around the royal courts is visible in inscriptions. Hinüber (2009: 168), after discussing a number of examples, speaks of "die sprachliche Welt der Brahmanen, die die Kanzleien beherrscht haben". He then continues: "Daher überlagert der Sprachgebrauch der Kanzleien der Herrscher die sprachlichen Bedürfnisse der Buddhisten nach einer terminologisch korrekten, vor allem dem Vinaya gemässen Ausdrucksweise. Es prallt also die Tradition der Texte des buddhistischen Kanons auf eine zweite, in den Kanzleien gepflegte, gegen die sich, wie die Inschriften zeigen, die Buddhisten oft nur ein wenig mühsam sprachlich behaupten können."
} 
treatises that might compete with the brahmanical Arthaśāstra, or with the Laws of Manu. But are there cases where a majority of Buddhists was happy to be governed by a king assisted by Brahmins?

Such examples exist. Some particularly clear ones lie beyond the boundaries of the Indian subcontinent. Brahmanical influence, once it had started to spread, did not stop at these boundaries. It moved on right into the countries of Southeast Asia. There, too, it proceeded essentially in the same way as in South Asia: It did not convert people, least of all the common population. No, it assisted the local rulers in ways with which we are now familiar: by offering ritual support and expertise in running the state. Numerous Sanskrit inscriptions from almost all countries of that region testify to the presence of Brahmins and their activity in and around the royal courts. ${ }^{277}$

This did not change when these countries converted to Buddhism! Brahmins played until recently an important ceremonial role at the Burmese and Cambodian courts, and they still do so in Thailand. About Thailand, for example, we read in the scholarly literature: ${ }^{278}$

Though the Thai were Buddhists, their kings surrounded themselves with the appurtenances of Khmer royalty, and recruited their Court Brahmans from Cambodia. For centuries, indeed, Brahmanism enjoyed quite an important position; for although Buddhism was the religion of the people, and was protected by the kings, Hinduism was still considered as essential to the monarchy, and so received a great share of royal favour. The famous inscription (about A.D. 1361) of King Dharmarāja I mentions the king's knowledge of the Vedas and of astronomy, ${ }^{279}$ while the inscription on the Śiva statue found at Kāmbèn Bejra records the desire of King Dharmaśokarāja to exalt both Hinduism and Buddhism. And this is as late as A.D. $1510 .^{280}$

Peter Skilling (2007: 199), citing a publication by Griswold and Prasert that is not accessible to me, observes "that the courts of South-East Asian rulers had brahmans 'to advise on statecraft, law and technical matters; to regulate the

\footnotetext{
${ }^{277}$ See chapter II.3, above.

${ }^{278}$ Quaritch Wales, 1931: 60.

${ }^{279}$ References to Coedès, 1924: 98.

${ }^{280}$ References to Coedès, 1924: 159. For Buddhism in the Khmer empire, see Snellgrove, 2001.
} 
calendar and cast horoscopes; to manage the Swinging Festival, the First Ploughing, and rites for the control of wind and rain; to perform ceremonies; and to discharge a host of other tasks.",

The influence of Brahmins in historical Southeast Asia is known to us from an earlier chapter (II.2). What interests us in particular is that this brahmanical influence was independent of the religion or religions of the country concerned. Brahmins would still be there even if the country had become buddhist. This is of course precisely what we have seen before: Brahmanism stands for a social order. ${ }^{281}$ Buddhism in Southeast Asia accommodated itself to this social order. This was possible, because Buddhism and Brahmanism were not two religions in competition. Buddhism was rather a religion which had to adjust itself to this particular social order. Buddhism may not always have liked the brahmanical social order, but it could live with it where the latter was imposed. This happened several times in Southeast Asia (at least in theory). ${ }^{282}$ We will see below that the situation in South Asia was different, but not altogether different.

Before moving on, it will be useful to recall once again the situation in Sri Lanka. This island - or at least its Singhalese part — was buddhist for most of its history. The Singhalese kingdom, too, needed to be governed, and could do with good advice. Where did the Singhalese rulers look for such advice? As we have seen, they turned to brahmanical Sanskrit literature. The Ceylonese historical chronicles repeatedly mention various Sanskrit treatises of this kind that were consulted, most specifically the Arthaśāstra and the Laws of Manu. This is an example of a buddhist kingdom in which Sanskrit never predominated, but in

${ }^{281}$ Cp. Sanderson, 2004: 389: "Brahmanism, then, was certainly present among the Khmers, at least within the élite of society. But I see no evidence that it amounted to a fourth religion. The Indian Śaivas claimed to go beyond Brahmanism through practice authorized by their own, higher bodies of scripture; but they underwent Brahmanism's rites of passage, performed many of its regular ceremonies in addition to their own, and adhered to its regulations concerning such matters as caste-endogamy, inheritance, and the administration of law under royal authority. Only their path to salvation was peculiarly theirs. The Brahmanism that we find among the Khmers was of this subsidiary kind. There is no trace of the exclusive variety that many in India considered to be the sole means of access to salvation, denying the validity of the Śaiva and Vaiṣnava scriptures."

${ }^{282}$ Bhattacharya (2006: 1), for example, refers to a buddhist king of Cambodia from the $12^{\text {th }}$ century who boasts that in his hospitals "all the four social classes are to receive medical treatment" (cikitsyā atra catvāro varnāhh). 
which brahmanical political ideas yet exerted a strong influence.

These examples from Southeast Asia should not make us forget that the relationship between Brahmanism and Buddhism was complex in the South Asian subcontinent as well. The double loyalty of King Harșavardhana in the first half of the seventh century CE can serve as example. About him, Réné Grousset said: ${ }^{283}$

Harșa never broke with official Brahmanism, nor even with the Hindu sects, any more than the other Indian sovereigns of his time. [Xuanzang] depicts him as loading the Brahmans with gifts, and in his works he himself declares that he is a worshipper of Śiva; his confident and friend, the novelist Bāna, was, moreover, Brahman by caste and Hindu by religion. But the personal sentiments of the monarch were clearly Buddhist, and of the Mahāyāna school. In the Mahāyāna even, his sympathies appear to have attached him to the Yogācāra school, as it was taught in the monasteries of Nālandā, and as [Xuanzang] professed it. This tells us how close was to be the bond between these two. Indeed, during the few weeks they spent together, a firm friendship grew up between the Indian maharajah and the Chinese pilgrim.

About King Vikramendravarman I of Āndhra, who ruled during the first decades of the sixth century, Sanderson reports the following (2009: 71-72):

A ... set of plates discovered at Tummalagudem contains a charter issued by Vikramendravarman II which records his granting a village for the support of the Buddhist community at [a] monastery. The founder's husband Govindavarman I is described as having beautified the whole of the Deccan with splendid Stūpas and monasteries, and Vikramendravarman I, his grandson and the grandfather of Vikramendravarman II, is identified as paramasaugatah "entirely devoted to the Buddha'. However, in a charter issued by Vikramendravarman II in the previous year, recording a grant of a village to a Śaiva temple, he is referred to as paramamāheśvarah, as is his father Indrabhatțārakavarman, drawing to our attention that if a king supported Buddhism he did not necessarily cease to support other faiths or abandon his own.

We have come to think that Buddhism - more or less consciously, and more or less willingly — left a considerable number of activities to Brahmins. The list we

${ }^{283}$ Grousset, 1932: 205-06; cited in Hazra, 1995: 90. 
have considered so far is no doubt not exhaustive. A complete list will be difficult to establish, given that there are no explicit statements in the buddhist texts to the effect that this or that field of activity was left to Brahmins. To the list of items enumerated so far, it seems likely that at least one more can be added: the realm of rituals that accentuate major events in the life of an individual. Unlike Buddhism, Brahmanism had a whole series of these. One reason to believe that many Buddhists availed of the existence of these rites is a statement by the brahmanical philosopher Udayana in his Âtmatattvaviveka. Udayana states: ${ }^{284}$ "There is no philosophy (darśana) in which people, even if they claim that [the world is] illusory, do not perform the vedic rites ${ }^{285}$ from impregnation ( arbhädhāna) to funeral rite (antyești) ${ }^{286}$ or do not agree that there is a distinction between touchable and untouchable [people] and so on; or in which people do not, in the case of a transgression, perform expiations such as sipping water, bathing, etc." Udayana lived in the tenth century, at a time when rites had become important in Buddhism, as we will see in a later chapter. But these were tantric rites, whereas Udayana refers explicitly to vedic domestic rites (vaidik $\bar{l}$ $k r i y \bar{a}){ }^{287}$ These domestic rites may have been in use for a long time, also among Buddhists, perhaps from the time Indian Buddhism agreed to leave certain aspects of ordinary life, i.e., life in society, to the Brahmins and their customs.

\footnotetext{
${ }^{284}$ Udayana, Ātmatattvaviveka, ed. Dravid, p. 413 (corrected): nāsti eva taddarśanam yatra sāmvvrtam ity uktvāpi garbhādhānādyantyeștiparyantām vaidikịm kriyām janah na anutișthati, spṛ́syāspṛ́syādivibhāgam vā na anumanute, vyatikrame ca ācamanādisnānādiprāyaścittạ̣ vā na anutiș̣thati.

285 "Gunaprabha, in his Vinayasütra [...], reminds the monks of the need to conduct festivals that celebrate the Buddha's birth $(j \bar{a} t i)$, the shaving of his hair (jațā) at the age of five, the putting aside of the top-knot ( $c \bar{u} d \bar{a})$ at the age of six" (Pagel, 2007: $371 \mathrm{n} .3$ ).

${ }^{286}$ On the antyesți, see note 605 , below. Note further that there is also a Śaiva funerary rite called antyestiti; see Sanderson, 1995: 32.

${ }^{287}$ This does not mean that buddhist monks had not been involved in ritual in earlier days; Schopen (1992a) draws attention to passages in three distinct Vinaya traditions that both assume and enjoin monastic participation in at least some domestic, lay life-cycle rituals.
} 


\section{III.2 Science and religion in classical India}

We had occasion to observe in the preceding chapter that the Buddhists left certain sciences to the Brahmins. This is correct, but in need of further precision. The attitude of both Brahmanism and Buddhism toward the sciences was complex. This chapter will offer a first analysis, taking as point of departure the attitude toward the sciences in the Christian Middle Ages.

David S. Landes, author of The Wealth and Poverty of Nations: Why some are so rich and some so poor (1998), is interested in what he considers one of history's great questions, namely: Why was Europe different? Part of the answer to this question can be found, he states, ${ }^{288}$ in a book by David F. Noble, called The Religion of Technology: The divinity of man and the spirit of invention (1999). In this book Noble draws attention to the religious roots and spirit of Western technology. He traces the Western idea of technological development from the ninth century, when the useful arts became connected to the concept of redemption, up to our own time, as humans begin to exercise Godlike knowledge and powers with nuclear weapons, manned space exploration, Artificial Intelligence, and genetic engineering. The link with redemption, he notes, is not known to have existed before the ninth century. Noble (p. 16) mentions in particular Martianus Capella's fifth-century work The Marriage of Philology and Mercury (in Latin: de nuptiis Philologiae et Mercurii). In this work, Mercury gives his new bride the gift of seven arts - Grammar, Dialectic, Rhetoric, Geometry, Arithmetic, Astronomy, and Harmony - each represented in a performance by a maiden. Capella omits the two mechanical disciplines Medicine and Architecture, because of their "baseness" and "unworthiness". This is justified in the following words: "Since these ladies are concerned with mortal subjects and their skill lies in mundane matters, and they have nothing in common with the celestial deities, it will not be inappropriate to disdain and reject them." 289 This changed with the Carolingian philosopher John Scotus Erigena, who commented upon this work, and rewrote Capella's allegory so as to include

\footnotetext{
${ }^{288}$ In a review published in the Los Angeles Times and reproduced on the back cover of Noble's The Religion of Technology.

${ }^{289}$ Stahl \& Johnson, 1977: 346.
} 
the hitherto disdained mechanical arts. In Erigena's version, the bride Philology first receives Mercury's gift of the liberal arts, then gives him in return the parallel gift of seven mechanical arts, including Medicine and Architecture. In this way the mechanical arts are introduced, ${ }^{290}$ and are represented as having equal significance as the liberal arts. A new attitude towards these arts manifests itself here for the first time. Henceforth it accompanies them and their successors until the present day. This new attitude, according to Noble, has a clearly religious dimension.

It cannot be our task to pronounce on the correctness or otherwise of Noble's thesis. It should of course not be forgotten that many centuries were still to elapse between the Carolingian Erigena and the European Renaissance, centuries during which European technical and scientific prowess did not reach the height of certain other civilisations, most notably that of China. It will nevertheless be interesting to ask whether, and to what extent, religious attitudes may have played a role in the development of science in India. A study of this question will throw light on the sometimes complex interaction between Brahmanism and Buddhism.

According to Martianus Capella, then, the two disciplines Medicine and Architecture "are concerned with mortal subjects and their skill lies in mundane matters". This in its turn allowed him "to disdain and reject them", and to contrast them with Grammar, Dialectic, Rhetoric, Geometry, Arithmetic, Astronomy, and Harmony, which are obviously not concerned with mortal subjects and which do not deal with mundane matters. The Indian enumerations of sciences are very different from the Western medieval enumeration of arts, but a superficial comparison of some items is possible. India, like Europe, had a tradition of Medicine, which by its very nature dealt with mortal subjects and mundane matters. Are there reasons to think that in India, too, Medicine was looked down upon by comparison with sciences that deal with "higher" matters? ${ }^{291}$

\footnotetext{
${ }^{290}$ Erigena appears to be the first whose use of the expression artes mechanicae has survived, but he may not have been the first to use it; cf. Sternagel, 1966: $30 \mathrm{f}$. See further Whitney, 1990.

${ }^{291}$ For inscriptional evidence for the existence of Brahmins who practised the medical profession, see Gupta, 1983: $32 \mathrm{f}$.
} 
There are. Already in vedic literature it is clear that the profession of a physician is progressively becoming less respectable. The Taittirīya Samhitā (6.4.9.1 f.) has the following to say about the two Aśvins, divine physicians: "The gods said of the two: Impure are they, wandering among men as physicians. Therefore a Brahmin should not practice medicine, for the physician is impure, unfit [to participate] in sacrifice." ${ }^{292}$ And the Āpastamba Dharmasūtra (1.19.14) contains the following verse, which it ascribes to a Purāna: "It is forbidden to eat the food of physicians, hunters, surgeons, fowlers, unchaste wives, or eunuchs." 293 The Vasiștha Dharmasūtra (14.2), similarly, states: "The following are unfit to be eaten: food given by a physician, a hunter, a harlot, a law enforcement agent, a thief, a heinous sinner, a eunuch, or an outcaste." ${ }^{, 294}$ And again (14.19): “Almsfood given by physicians, hunters, surgeons, fowlers, eunuchs, and unchaste wives is not to be accepted even if it is given unasked." 295 The Mānava Dharmaśâstra (3.152) counts physicians among those to be excluded from certain privileges: "Doctors, priests who attend on idols, people who sell meat, and people who support themselves by trade are to be excluded from offerings to the gods and ancestors. ${ }^{296}$ Elsewhere this same text (10.46-47) counts medicine (cikitsita) among the occupations despised by twice-born (dvijānām nindita karman), and specifies that this one should be practised by the Ambasthas. The Mahābhärata (12.37) enumerates the physician along with those who live by dancing or singing, clowns, a drunk, a crazy man, a thief, one who cannot speak, one whose skin is discolored, one who is missing a limb, a dwarf, a villain, and others; a virtuous man should not give gifts to them. ${ }^{297}$ Elsewhere (3.124.9), the following observation about the Nāsatyas is put in Indra's mouth: "I hold that

\footnotetext{
${ }^{292}$ Scharfe, 2002: $252 \mathrm{f}$.

${ }^{293}$ Olivelle, 2000: 56-57: cikitsakasya mrgayoh śalyakrntasya pāśinah/ kulatāāāh sandhakasya ca teșām annam anādyam//

${ }^{294}$ Olivelle, 2000: 404-05: cikitsakamrgayupuṃścalīdaṇdikastenābhiśastașaṇdhapatitānām annam abhojyam. ${ }^{295}$ Olivelle, 2000: 406-07: cikitsakasya mrgayoh śalyahartus tu pāśinah/ śandhasya kulațāyāś ca udyatāpi na grhyat[e]//

${ }^{296}$ Manu 3.152: cikitsakā devalakā māmsavikrayoṇas tathä/ vipaṇena ca jīvanto varjyāh syur havyakavyayoh//; tr. Doniger \& Smith, 1991: 59

${ }^{297}$ Mhbh 12.37.29-31: na dadyād .../ na nrttagītaśîleșu hāsakeșu ca dhārmikahl/ na matte naiva conmatte na stene na cikitsake/ na vāgghīne vivarne vā nāngahìne na vāmanel/ na durjane dauṣkule vā vratair vā yo na samskrtah/; tr. Fitzgerald, 2004: 252.
} 
these two Nāsatyas are unworthy of the Soma. Since they are healers to the sons of the Gods, their calling excludes them."298

A number of Purānic passages suggest that not only the medical profession, but also mathematics/astrology/astronomy ${ }^{299}$ was frowned upon in classical India. In a list of sinners drawn up by Marc Tiefenauer — in a study about the Purānic hells (2001: 106-108) — we find a number of unexpected terms, among them gaṇaka, nakṣatrapāțaka, nakṣatrasūcaka, nakṣatrin, and cikitsaka. The first four of these terms refer to astrologers and/or mathematicians; the last one to medical doctors.

Tiefenauer's list of 54 different terms contains some further surprises (why, for example, is it a sin to be a potter?), but the two noted above deserve further reflection. Neither medicin nor astral studies are in any way in opposition to the Sanskrit tradition. Medicin (āyurveda) can boast of some important early treatises in Sanskrit, and counts as an Upaveda. Astral studies (jyotih) is nothing less than a Vedānga, a "limb of the Veda"! ${ }^{300}$ Thakur (1981: 197) suggests that the opposition against the latter "was natural because astrological practices were contradicting the very basis of brāhmanical philosophy. While the brāhmanical philosophy emphasised the theory of karma the astrologers bred an altogether different view of life, i.e., bhāgyavāda or fatalism." This proposed explanation must however be looked upon with scepsis. Brahmanical religion allowed various sometimes mutually contradictory points of view with regard to one's future destiny to coexist, and some of the most conservative Brahmins, the Mīmāmsakas, had no place for the theory of karma right up to the middle of the first millennium $\mathrm{CE}$ and beyond.

However, the critical attitude towards astrology was not confined to the Purānas. The Mānava Dharmaśāstra forbids this activity to those Brahmins who,

\footnotetext{
${ }^{298}$ Mhbh 3.124.9: ubhāv etau na somārhau nāsatyāv iti me matih/ bhișajau devaputrāṇām karmaṇa naivam arhatah̆//. Tr. van Buitenen. Cp. Brinkhaus, 1978: 90.

${ }^{299}$ These three are quasi-inseparable, as Albiruni confirms; cf. Sachau, 1888:152: "The science of astronomy is the most famous among them, since the affairs of their religion are in various ways connected with them. If a man wants to gain the title of an astronomer, he must not only know scientific or mathematical astronomy, but also astrology."

${ }^{300}$ Inscriptional evidence confirms that brahmanical astrologers sometimes received strong support from the royal court; see Gupta, 1983: $24 \mathrm{ff}$.
} 
having abandoned all their possessions, spend the fourth quarter of their life wandering (pra- or pari-vraj): ${ }^{301}$

He must never try to obtain almsfood by interpreting portents or omens, by his knowledge of astrology or palmistry, by giving counsel, or by engaging in debates.

Elsewhere this same text (Manu 3.162-166) stipulates that an astrologer by profession (nakșatrair yaś ca jivvati) counts among those who should be diligently avoided (varjanīyāh prayatnatah). The inevitable question is: why should brahmanical texts be critical with regard to people who practise a Vedānga? To find out, we have to turn to the attitude of Buddhism with regard to the sciences.

Buddhist texts mention five sciences (vidyāsthāna or sthāna). An enumeration occurs under verse 11.60 of the Mahāyānasūtrālaṃkāra (Sūtrāl(B) p. 70 1. 10-11): pañcavidham vidyāsthānam/adhyātmavidyā hetuvidyā śabdavidyā cikitsāvidyā śilpakarmasthānavidya ca/"Science is fivefold: the science of the self, the science of logic, the science of words, the science of medicine, and the science of arts and crafts (?)." We learn from the same text that a Bodhisattva "investigates the science of logic and the science of words to defeat others who are not so inclined, the science of medicine and the science of arts and crafts to help others who need it, and the science of the self to obtain perfect knowledge for himself." ${ }^{302}$ These five sciences are referred to in a number of works in connection with the education of a prince. ${ }^{303}$

The precise range of each of the five sciences is not in all cases equally simple to determine. The sciences of logic, words and medicine do not appear to be particularly problematic. The science of the self looks at first somewhat surprising in that most Buddhists reject the very existence of a self; perhaps it

\footnotetext{
${ }^{301}$ Manu 6.50: na cotpātanimittābhyām na nakșatrāingavidyayā/ nānuśāsanavādābhyāṃ bhikșām lipseta karhi cit//. Tr. Olivelle. This same verse occurs in the Vasiștha Dharmasūtra (10.21).

${ }^{302}$ Sūtrāl(B) p. 70 1. 12-14: ... hetuvidyām śabdavidyām ca paryeșate nigrahārtham anyeșām tadanadhimuktānām/ cikitsāvidyām șilpakarmasthānavidyām cānyeșām anugrahārtham tadarthikānām/ adhyātmavidyām svayam ājñārtham/ ${ }^{303}$ BHSD s.v. vidyā-sthāna, sthāna.
} 
would be more correct to translate "science concerning oneself". It seems plausible that it covers much of what we would call buddhist philosophy, which concerns the inner constitution of the person, and competes with brahmanical philosophies that do centre on the nature of the self. The term "science of arts and crafts", finally, is obscure, and it is not impossible that this category would in practice be used, if at all, to find a place for areas of knowledge not covered by the other four sciences.

It is yet striking that astrology, astronomy and mathematics are absent from this list. It is all the more so when we recall that we have no knowledge of any buddhist contributions to this science. ${ }^{304}$ This is in marked contrast with the contributions made by Buddhists to other areas of knowledge. Buddhists played an important role in the development of logic, of medicine, and of grammar. Buddhist philosophy has been particularly rich, and constituted for a long time a major challenge to brahmanical thinkers. The areas just mentioned, be it noted, correspond to four of the five "sciences" enumerated above. Whatever developments there have been in the area of astrology, astronomy and mathematics - which do not figure among the five sciences — are due to the efforts of brahmanical and jaina thinkers; ${ }^{305}$ for reasons that remain to be elucidated, the Buddhists did not participate. ${ }^{306}$

\footnotetext{
${ }^{304}$ See Pingree, 1981; Plofker, 2009.

${ }^{305}$ Note however Bapat, 1928: 97 ("He [a jaina monk, like a buddhist monk] does not engage himself in any worldly trades, nor does he earn his livelihood by prescribing medicines or by interpreting signs, prognostications or dreams or by telling prophecies") with references to Āyār I.2.5.4,13.2.14; Utt II.33, VIII.13, XV.7, XX.45; Sūy I.12,9-10 I.14.19; SN 360, 927, 929; DN I.23-25.

${ }^{306}$ Note however Pingree, 2001: 655 ("In or shortly before 1055 Daśabala, an astronomer from Gujarât (he belonged to the Vālabhyānvaya) who enjoyed the buddhist title Mahākārunika Bodhisattva, composed a set of tables for computing tithis, nakṣatras, and yogas entitled Cintāmaṇi") with a reference to D. Pingree, The Astronomical Works of Daśabala, Aligarh: Viveka Publications 1988 (Aligarh Oriental Series 9), inaccessible to me. Yano (1987), moreover, discusses a Chinese text on Indian astrology, whose "author is the buddhist monk Amoghavajra (A.D. 705-774) whose native place was somewhere in north India" (p. 125); Yano comments, however, that "Amoghavajra's knowledge of Indian astrology [...] is far from professional" (p. 133). Amoghavajra's interest in astrology may have to be explained in the light of his tantric connections; see chapter III.8, below. The Mūlasarvāstivāda Vinaya does allow monks to calculate dates; see Salomon, 2001: 249-250, with a reference to Schopen, 1998: 173. Scharfe (2002: 158) comments on the absence of mathematics and astronomy/astrology in the list of sciences taught at Nālandā.
} 
The one apparent exception to this observation turns out, at closer inspection, to confirm it. The long presentation of astronomical and astrological knowledge in the Śărdūlakarṇāvadāna (practically the whole of which was translated into Chinese already in the third century CE; see Mukhopadhyaya, 1954: xii f.; 1967: 71 f.; Burrow, 1956) $)^{307}$ is put in the mouth of Triśanku, the king of the Mātangas, and is part of his attempt to show the Brahmin Puṣkarasārin that he is well acquainted with brahmanical knowledge, and his son therefore worthy of the latter's daughter. Pușkarasārin enumerates a long list of items which, in his opinion, justify the Brahmins' elevated position in society. ${ }^{308}$ Beside a number of terms that refer to vedic or related knowledge, there are several that are connected with astronomy and astrology: the zodiac (mrgacakra), constellations (nakșatragaṇa), lunar days (tithikramagaṇa), eclipses (?; rāhucarita), the course of the planet Venus (?; sukracarita), the courses of the planets (grahacarita). Triśanku is able to show Puṣkarasārin that he masters brahmanical knowledge as well as his interlocutor. This demonstration contains lots of information about the Veda (including the quoted Sāvitrī-mantra, RV 3.62.10) and other things of importance to Brahmins, including precisely a long section about astronomy and related matters. ${ }^{309}$ This does not therefore indicate that the Buddhists were interested in this, but rather that they looked upon

\footnotetext{
${ }^{307}$ Another name appears to be Mātañgī Sūtra. Nakamura (1980: 318) states: "This sūtra (i.e., the Mātañgi Sütra, J.B.), translated into Chinese in the third century, was most likely compiled in Samarkand, judging from its astronomical informations." Regarding the origin or justification of this opinion, Nakamura gives no further information than that contained in his note 54: "Zenba in Tōa Sekai-shi (...), published by Kōbundō (...), vol. 2, p. 264." Yano (2005: 45) makes the following observation about this text: "The Śărdūlakarṇāvadāna, a part of Divya-avadāna, is one of the few Sanskrit texts in which the earlier stage of Indian astrology is systematically described. The date of this text is not known, but the knowledge of astrology in this text shows that the original part was formed sometime in the first to the second century A.D."

${ }^{308}$ Mukhopadhyaya, 1954: 31; Divy(V) p. 328 1. 9-13. The complete list enumerates the following items: Rgveda, Yajurveda, Sāmaveda, Atharvaveda, Āyurveda, Kalpa, Adhyātma, Mrgacakra, Nakṣatragaṇa, Tithikramagaṇa, Karmacakra, Añgavidyā, Vastravidyā, Śivāvidyā, Śakunividyā, Rāhucarita, Śukracarita, Grahacarita, Lokāyata, Bhāṣyapravacana, Pakṣādhyāya, and Nyāya.

${ }^{309}$ Mukhopadhyaya (1954: x f.) recalls that Triśanku in brahmanical literature (Rāmāyaṇa, Mahābhārata, Harivamśa, Viṣnu Purāna, Bhāgavata Purāna) is the name of a king who was first degraded to the rank of Caṇ̂āla and subsequently became a constellation suspended in the air; the fact that Triśanku himself forms one of the constellations might explain that he says so much about the nature, characteristics, movements and activities of the constellations.
} 
astronomy and astrology as being typically cultivated by Brahmins. We will come back to this point below.

Why did the Buddhists not participate in the development of what came to be known as jyotihśāstra, which combines astronomy, astrology and mathematics? To find an answer to this question it will be useful to recall what jyotiḥsāstra consists of: "Traditionally jyotiḥsāastra is divided into three skandhas: saṃitā (omens), gaṇita (astronomy), and horā (astrology) [...] The validity of [this] tradition was maintained only by artificially including new forms of scientific writing - e.g., treatises on mathematics, on muhūrta, or on praśna in one or another of the three skandhas [...]" (Pingree, 1981: 1). Unlike Geometry, Arithmetic and Astronomy in the early European tradition, jyotihśastra was not originally, or in essence, far removed from mundane matters. Quite on the contrary, it may have been inseparably connected with mundane matters, in that those who practised it may often have had to make their living through explaining omens and predicting the future with its help. Such practices were however frowned upon in the buddhist tradition from an early date onward. The following passage occurs in a number of early buddhist sermons, and was believed to give expression to the Buddha's position in this matter (tr. Walshe, 1987: 71-72): ${ }^{310}$

Whereas some ascetics and Brahmins, feeding on the food of the faithful, make their living by such base arts, such wrong means of livelihood as palmistry, divining by signs, portents, dreams, body-marks, mousegnawings, fire-oblations, oblations from a ladle, of husks, rice-powder, rice-grains, ghee or oil, from the mouth or of blood, reading the fingertips, house- and garden-lore, skill in charms, ghost-lore, earth-house lore, snake-lore, poison-lore, rat-lore, bird-lore, crow-lore, foretelling a person's life-span, charms gainst arrows, knowledge of animals' cries, the ascetic Gotama refrains from such base arts and wrong means of livelihood. Whereas some ascetics and Brahmins make their living by such base arts as judging the marks of gems, sticks, clothes, swords, spears, arrows, weapons, women, men, boys, girls, male and female slaves, elephants, horses, buffaloes, bulls, cows, goats, rams, cocks, quail, iguanas, bamboorats, tortoises, deer, the ascetic Gotama refrains from such base arts. $[\ldots .$.

${ }^{310}$ DN I.9-11 (Brahmajāla Sutta $)=$ DN I.67-69 $($ Sāmañ̃̃aphala Sutta $)=$ DN I.100 $($ Ambațtha Sutta, pe $)=$ DN I.124 (Soṇadaṇda Sutta, pe $)=$ DN I.147 (Küțadanta Sutta, pe) $=$ DN I.157 (Mahāli Sutta, pe) = DN I.159 (Jäliya Sutta, pe) = DN I.170 (Kassapa Sìhanāda Sutta, pe). 
Whereas some ascetics and Brahmins make their living by such base arts as predicting an eclipse of the moon, the sun, a star; that the sun and moon will go on their proper course - will go astray; that a star will go on its proper course - will go astray; that there will be a shower of meteors, a blaze in the sky, an earthquake, thunder; a rising, setting, darkening, brightening of the moon, the sun, the stars; and 'such will be the outcome of these things', the ascetic Gotama refrains from such base arts and wrong means of livelihood.

Whereas some ascetics and Brahmins make their living by such base arts as predicting good or bad rainfall; a good or bad harvest; security, danger; disease, health; or accounting, computing, calculating, poetic composition, philosophising, the ascetic Gotama refrains from such base arts and wrong means of livelihood.

[.....]

Whereas some ascetics and Brahmins, feeding on the food of the faithful, make their living by such base arts, such wrong mean of livelihood as appeasing the devas and redeeming vows to them, making earth-house spells, causing virility or impotence, preparing and consecrating buildingsites, giving ritual rinsings and bathings, making sacrifices, giving emetics, purges, expectorants and phlegmagogues, giving ear-, eye-, nose-medicine, ointments and counter-ointments, eye-surgery, surgery, pediatry, using balms to counter the side-effects of previous remedies, the ascetic Gotama refrains from such base arts and wrong means of livelihood.

Passages like this were obviously a strong disincentive for future monks and nuns to occupy themselves with such activities, which include the activities that came to be associated with jyotiḩśāstra. And indeed, these practices - collectively referred to as "pseudo-sciences" (tiracchānavijjā) — are again rejected in the monastic rules (Vin II p. 139). The combination of these canonical passages with the appropriation of this field by Brahmins were apparently sufficient ground for Buddhists to abstain from participating in the development of mathematics, astronomy and astrology.

Interestingly, this abstention by Buddhists had some effect on Brahmins. We know that Buddhists and Brahmins did not like each other. The surviving literature of both is full of criticism that they addressed at each other. The history of Indian philosophy, for example, is in part the history of an ongoing battle between these two.

The profound distrust which Buddhists and Brahmins had for each other should not make us forget that the two lived for many centuries in the same areas, and could not but exert an enormous influence upon each other. The brahmanical 
obsession with ritual purity had an effect on the Buddhists, so much so that it finds expression in the Vinaya rules of the Mūlasarvāstivādins. ${ }^{311}$ We will see in chapter III.6, below, that this influence may be responsible for certain theoretical developments in Buddhism, such as the elaboration of the notion of dharmakaya. Here it is important to recall that this influence went both ways. Buddhist influence on Brahmanism can be shown to have taken place in various domains. In view of this, it is tempting to infer that the buddhist rejection of astrology and related activities infected orthodox Brahmanism. Indeed, activities that were not good enough for Buddhists could not possibly be good enough for Brahmins, or at least for certain Brahmins.

If this understanding is correct, we see that the historical development has gone full circle. Buddhists did not participate in anything connected with mathematics, astronomy and astrology, at least in part because they had ceded these activities to Brahmins. In return, certain Brahmins frowned upon these same activities, presumably at least in part because Buddhists looked upon them as improper.

Buddhist influence did not stop the development of astrology, astronomy and mathematics in Brahmanism. Indeed, brahmanical mathematics counts a number of remarkable accomplishments. Buddhists did not participate in these developments. And certain normative brahmanical texts, probably under buddhist influence, expressed themselves in negative terms about these sciences. Fortunately not all Brahmins were ready to obey these prohibitions.

\footnotetext{
${ }^{311}$ See, e.g., Schopen, 1992: 215 ff.
} 


\section{III.3 A new language}

Sometime during the early centuries CE, the Buddhists of northwestern India adopted Sanskrit. The present chapter will argue that this transformation cannot be dissociated from the confrontation with Brahmanism that Buddhism underwent, and will propose an explanation as to why it happened.

Regarding the exact time of the buddhist adoption of Sanskrit, the recently discovered Schøyen collection of manuscripts from Bamiyan provides some help. Richard Salomon (2006: 358) says the following about it:

The oldest fragments of that collection, which seem to date from about the late second or early third centuries CE, include manuscripts in both Gāndhārī and Sanskrit. This situation may reflect a transitional period during which the Kharoșthī script and Gāndhārī language were being gradually ... replaced in Greater Gandhāra by Brāhmī and Sanskrit ...

If it is true that Aśvaghoṣa, probably one of the first buddhist authors to write in Sanskrit, is to be dated in the first century $\mathrm{CE},{ }^{312}$ the period of transition must have covered the second century CE plus perhaps some decenniums before and after. $^{313}$

The adoption of Sanskrit is to be distinguished from the sanskritization of other languages such as Gāndhārī, but the two may be related. About the latter Salomon (2001: 248) makes the following observation:

The new manuscript material indicates a gradual movement toward sanskritization of Gāndhārī whose roots go back to the first century, but which seems to have intensified in the second century, apparently during the reign of Kanișka and his Kuṣanna successors. This agrees well with the chronology of hybridization as previously deduced for northern India from later Buddhist manuscripts and from inscriptions in Mathurā and surrounding areas. Thus the incipient sanskritization of Buddhist textual and epigraphic languages probably accelerated simultaneously in the two main centres of the Indian empire of the Kușānas, namely Gandhāra and

\footnotetext{
${ }^{312}$ Hiltebeitel, 2006: 233 f. Olivelle (2008: xix f.) argues for the second century CE.

${ }^{313}$ The tradition of a Sarvāstivāda synod under Kong Kanișka, though far from certain, is interesting in this connection. See Lamotte, 1958: 648; Dessein, 1999: I: xxv; II: 7 notes 68 and 69; Willemen et al., 1998: 116 ff.
} 
central northern India, and it is hard to avoid concluding that the bulk of the sanskritization of Buddhist literature took place under the Kuṣānas.

The period of sanskritization of Gāndhārī coincides, it appears, with the beginning of the transitional period during which the Buddhists of northwestern India shifted to Sanskrit. ${ }^{314}$

Whatever the precise limits of the period of transition, until that period the Buddhists had used regional languages, perhaps also some literary Middle Indic, but not Sanskrit. ${ }^{315}$ And indeed, why should they? Sanskrit was the language of the Brahmins, with whom the Buddhists had little in common. Buddhism had survived for centuries using other languages than Sanskrit, had developed a highly technical philosophy, and had lived in kingdoms and empires that had not used Sanskrit either. It may be worth repeating that the Middle Indic languages used or adopted by the Buddhists were not derived from Sanskrit, not even from the earliest form of Sanskrit we know, Rgvedic Sanskrit. The base dialect (or dialects) of Pāli, for example, was (were) in several points more archaic than Rgvedic Sanskrit. ${ }^{316}$ What, then, may have driven certain Buddhists to adopt the language of their most fearsome competitors?

One answer has been suggested by John Brough (1954: 368/147). According to him, the effort of these Buddhists to write Sanskrit was "to present their doctrine in the language of learning and prestige". This, however, begs the question. For why should Sanskrit, rather than any of the Middle Indic languages that were in use, be the language of learning and prestige? Sheldon Pollock's following critical remarks are therefore justified (2006: 513): “The adoption of Sanskrit by Buddhists after centuries of resistance is often explained by its being 'the language of learning' or possessing 'technical precision'. We are never told why, after five centuries, it suddenly became necessary or desirable for Buddhists to begin to participate in such learning, or indeed why the precision of the local languages of Buddhism (Gandhari, Tocharian, and so on), which had often been

\footnotetext{
${ }^{314}$ Fussman (1988: 17) emphasizes that sanskritization was no continuous process: "Le degré de sanskritisation d'un texte ne permet ... pas — à lui seul — de dater celui-ci, même relativement." See further Schopen, 2009: 191.

${ }^{315}$ See Hartmann, 2004.

${ }^{316}$ Oberlies, 2001: $6 \mathrm{f}$.
} 
vehicles for liturgy, metaphysical doctrine, and moral discourse, had suddenly failed." Pollock's remarks are justified, but they do not go far enough. There had not been "centuries of resistance" against Sanskrit on the part of the Buddhists of India, as he suggests, because there had been no pressure that had to be resisted. To state it once again, Sanskrit was the archaic language of a group of people, the Brahmins, whom the Buddhists had no particular reason to imitate or please.

Pollock (2006: 56-57) sums up the situation in the following words, and this time we can fully agree with him: "What exactly prompted the Buddhists to abandon their hostility to the [Sanskrit] language after half a millennium [...] and finally adopt it for scripture, philosophy, and a wide range of other textual forms, some of which they would help to invent, is a question for which no convincing arguments have yet been offered." Pollock further observes that in this process "newly settled immigrants from the northwest seem to participate centrally" (1996: 205-06). ${ }^{317}$

In order to make headway in answering this question, two issues have to be distinguished. One can easily imagine that Buddhism, which tended to adopt the language of the region in which it found itself, felt the need for a common language of communication. This is what Oskar von Hinüber (1989: 351) describes in the following words: "[...] as soon as Buddhism began to spread over a larger area, the development of a language widely understood became imperative. The linguistic medium answering this demand eventually, was a literary Middle Indic language adapted, but hardly invented by the Buddhists themselves. [...] Once the Buddhists began to adopt the literary language current at their times, they started to move away from the spoken language, and ended up almost automatically in a [...] Buddhist Middle Indic [...]"318 These remarks

\footnotetext{
${ }^{317}$ Perhaps the Sarvāstivādins played a key role here. Cp. Brough, 1954: 367 [146]: "in the case of the Sanskrit canon, it is obvious from comparing the Pali version that it is very largely constructed out of older material in some Prakrit dialect; but there seems to be no reason for assuming that it is anything other than a quite definite translation into Sanskrit, done at a specific period, when the Sarvāstivādins decided to adopt Sanskrit as their official language."

${ }^{318}$ In another article Hinüber (1983/1994) argues that Buddhist Middle Indic subsequently developed into Pāli and Buddhist [Hybrid] Sanskrit. See pp. 192-93: "Pāli and Buddhist Sanskrit have common roots and develop in the same direction for some time, until Pāli loses contact with the north shortly after the beginning of the Christian
} 
explain the adoption of a common Middle Indic language, which is the first issue to be distinguished. The second one is the adoption of Sanskrit, and here von Hinüber's remarks offer no help. For the Sanskrit adopted is, at least in the case of certain Buddhists, the real brahmanical Sanskrit, not some language close to it. To cite once again John Brough (1954: 368/147): "So far as concerns the Sarvāstivādin canon at least, there is no room to doubt that the authors fully intended to write Sanskrit, and they would have been surprised at the suggestion that they were writing in a language essentially Prakritic in nature ...."319 The question is, why? Don't forget that until that time Buddhism had never yet used Sanskrit. Buddhism had moreover flourished and expanded in empires and kingdoms that never used Sanskrit either. The only users of Sanskrit until the great transformation were Brahmins, and the Buddhists had no obvious reason to copy Brahmins.

Considering the above, the question why the Buddhists adopted Sanskrit presents itself as a deep mystery. Buddhism (i.e., certain schools of Buddhism) adopted a language which it had no religious, intellectual or ideological reasons to adopt. It seems evident that, in order to solve the mystery, it is necessary to take into consideration that something very similar happened in the political realm. There are no political inscriptions in Sanskrit that precede the middle of the second century CE. Before that date, political inscriptions in northern India had always used Middle Indic languages. Why did this change?

We have studied Pollock's position in this matter in an earlier chapter. Pollock rejects the essential role of Brahmins and Brahmanism in the political adoption of Sanskrit. To repeat once again his words (2006: 67): “The radical reinvention of Sanskrit culture seems to have occurred [...] in a social world where the presuppositions and conventions of vaidika culture were weakest: among newly immigrant peoples from the far northwest of the subcontinent (and

era and from that time onwards is disconnected from the further developments in the north of the subcontinent." In a presentation ("Linguistic experiments: language and identity in Aśokan inscriptions and in early buddhist texts") at the $14^{\text {th }}$ World Sanskrit Conference in Kyoto (2009), Hinüber showed that the old Buddhist Middle Indic shared linguistic features with the Aśokan Girnar inscription, "as if inspired by the 'linguists' of Girnar".

${ }^{319}$ This does not exclude, of course, that Buddhists in the Sanskrit tradition might occasionally make mistakes; see e.g. MacDonald, 2007; further Hinüber, 2002: 156. 
ultimately from Iran and Central Asia), most importantly the Śakas (the so-called Indo-Scythians), especially a branch of the Śakas known as the Western Kṣatrapas, and the Kuṣānas.”

In order to evaluate this rejection we have to be clear what is meant by vaidika culture or rather, whether vaidika culture has a role to play in this discussion. For all those who are not practising Brahmins themselves, Brahmanism is not, or not primarily, the religious culture which finds expression in the vedic texts. Brahmanism, as we have seen, implies for them a sociopolitical order. Rulers can adopt this order without "converting" to Brahmanism. Strictly speaking, Brahmanism did not make converts, at least not religious converts. It promoted a vision of society, and brahmanical influence will manifest itself through this vision as much as, if not more than, through the performance of sacrifices.

With this in mind, let us look once more at the first important political Sanskrit inscription, the celebrated inscription of the Kṣatrapa king Rudradāman, dating from shortly after $150 \mathrm{CE} .{ }^{320}$ This inscription, to be brief, mentions a Vaiśya, refers to "all the varṇas", and points out that Rudradāman had undertaken a major work "in order to [benefit] cows and Brahmins for a thousand of years". As observed in an earlier chapter, it seems clear that the use of Sanskrit in this inscription gives expression to the wish to seek alignment with the brahmanical elite. Recall further that the brahmanical vision of society is, with few exceptions, absent from South Asian inscriptions that are not in Sanskrit and whose makers or instigators have no association with Brahmanism.

Let us now return to the Buddhists of northern India. These Buddhists had ceded the task of giving political and societal advice to Brahmins. The result was that political thought and its language of expression had become Sanskrit. What is more, Sanskrit had become the official court language. If and when Buddhists wanted or had to plead their cause at the royal court, they had to do so in Sanskrit.

The Buddhists did indeed need a great deal from the royal court. From the time they adopted rules allowing their community to receive donations, Buddhism had become more than before dependent upon royal protection and generosity.

\footnotetext{
${ }^{320}$ See chapter II.2 above. For earlier Sanskrit inscriptions, see Salomon, 1998: $86 \mathrm{f}$.
} 
Indeed, Buddhism had become a religion with sometimes big monasteries and stūpas to maintain. To cite a recent study by Gregory Schopen (2007: 61): "Even in the later [i.e., later than Aśoka] inscriptions from Bharhut and Sanchi there are no references to vihäras, and they begin to appear — though still rarely — only in Kharoșthī records of a little before and a little after the Common Era, about the same time that the first indications of permanent monastic residential quarters begin to appear in the archaeological record for the Northwest, and this is not likely to be mere coincidence. ... Permanent quarters, to remain so, required upkeep and maintenance; such maintenance required donations beyond mere subsistence; such donations required the further maintenance of long-term relationships with donors." Among these donors, we may add, we must count the royal court. The Buddhists, therefore, had to defend their interests at the court, but how could they do so?

The Buddhists of northwest India had one trump card. As we saw in the introduction, they had turned traditional buddhist teaching into a coherent whole, into a vision of the world and of man's place in it that could answer most (ontological and soteriological) questions. They had a message for every individual interested in his or her own future well-being, including the king. They could therefore challenge the Brahmins at the court, not in the realm of practical policy decisions to be sure, but rather in that of the spiritual well-being of the king, and of everyone else.

We do not know for sure how exactly, or how often, such challenges at the court took place during the early centuries of the Common Era. The brahmanical Arthaśāstra emphasizes the need of unrestricted access to the king for all those who need it (1.19.26-29; tr. Kangle):

Arriving in the assemblee hall (upasthāna), [the king] should allow unrestricted access ( $a d v \bar{a}$ rāsanga) to those wishing to see him in connection with their affairs. [...] he should look into the affairs of temple deities, hermitages ( $\bar{a}$ śrama), heretics ( $p \bar{a} s a n d a)$, Brahmins learned in the Vedas (śrotriya), cattle and holy places, of minors, the aged, the sick, the distressed and the helpless and of women, in [this] order or in accordance with the importance of the matter or its urgency. 
The primary aim of these legal courts may have been to provide justice to those in need of it, but more recent sources (which we will consider in a later chapter) suggest that these same legal courts were the ideal platform for disagreements of a philosophical and ideological nature. ${ }^{321}$ Perhaps this is not surprising. Serious disagreements between Brahmins, Buddhists and other heretics were no doubt often linked to the proprietorship of monasteries, hermitages and temples, ${ }^{322}$ and their resolution may at times have necessitated a presentation of the own disciplinary tradition (vinaya) or a philosophical confrontation. The passage of the Arthaśāstra just cited gives absolute priority to matters relating to religious real estate, and one can easily imagine that such matters might lead to debates about disciplinary or doctrinal points. ${ }^{323}$

Let us return to the buddhist adoption of Sanskrit. The Buddhists might be called upon to defend their interests at the royal court through legal or philosophical debates in Sanskrit. This left them little choice. All their textual material had to be available in Sanskrit, and the Buddhists themselves had to be able to express themselves competently in that language. ${ }^{324}$ The result is known. Sometime

\footnotetext{
${ }^{321}$ Schlingloff (2006) shows how the audience hall of the king is depicted in the painting of Ajanta.

${ }^{322}$ Even though vedic religion knew no temples, certain Brahmins in more recent times were associated with them. They yet maintained to belong to a vedic tradition, and made efforts to use vedic devices in their temple rituals. See, e. g., Colas, 1999.

${ }^{323}$ See further chapter III.6, below.

${ }^{324}$ Strictly speaking, this argument does not apply to texts whose use was largely or even exclusively internal to the buddhist community. Fussman (2008: 179) therefore concludes: "la mise en sanskrit de textes à usage uniquement interne, les vinaya, ne trouve d'explication que dans un besoin de communication interne à la communauté". This may conceivably be correct, but it is not altogether evident that Vinaya texts might no have their role to play in legal debates, if and when they took place in court. It would be interesting to know whether Vinaya texts were, on average, translated into Sanskrit later than dogmatic texts.

Fussman's (2008: 179) claim that Pollock (2006: 39 ff.) cites numerous brahmanical texts to the extent that "le sanskrit est le privilège des trois plus hauts varna, les śüdra en sont exclus" does not appear to be correct: as far as I can see, Pollock cites only one such interdiction, from a very late (sixteenth-century) Sanskrit text (p. 43-44). This is hardly surprising, given the general brahmanical belief during the earlier period that Sanskrit is the only true language; at least in theory, depriving people of Sanskrit would be depriving them of speech. Súdras were, to be sure, excluded from the ritual and ascetic practices associated with Sanskrit (including the use of mantras), but this is an altogether different matter. Non-ritual texts, such as the Sanskrit epics, would certainly be allowed
} 
during the second century CE the Buddhists of northwestern India shifted wholesale to Sanskrit. They did not do so because they liked Sanskrit, or because they liked the Brahmins whose language it was. Nor did they do so for some inherent quality that this language supposedly possesses. They did so because they needed to defend their interests at the royal courts in Sanskrit. They had to use Sanskrit at the courts because Brahmins had been able to secure themselves a central place at the courts by way of their indispensable skills, not because rulers had supposedly "converted" to Brahmanism. This, as far as I can see, is the most plausible explanation of this otherwise puzzling change of language.

The skills which made Brahmins indispensable at the courts were, first of all, the ones already discussed: they provided supernatural protection and political and societal advice. We may add their skills in astrology and related matters. These include the mastery of complex and precise calendrical systems. Richard Salomon (2001: $249 \mathrm{f}$.) singles this out in particular while discussing the specific motivations and forces behind sanskritization. He is no doubt right in doing so but, I would like to suggest, the brahmanical bag of tricks contained far more than only the ability to work with calendars. What is more, it seems likely that the pressure exerted on the Buddhists, which was strong enough to actually make them change language, reached them primarily through the intermediary of the royal court.

\section{Appendix to chapter III.3: Jainism, Mathurā and Sanskrit}

Like Buddhism, Jainism was born in Greater Magadha. The Jina and the Buddha are supposed to have been contemporaries, and there are indeed early buddhist text that mention Mahāvīra's demise. The two movements were aware of each other's existence, and there are good reasons to believe that they influenced each other. This influence was, as far as the earliest period is concerned, largely unidirectional: there is for this period much more evidence for jaina influence on 
Buddhism than the other way round. ${ }^{325}$ The direction of influence was reversed in a more recent period, and in a different region of the subcontinent.

Both Jainism and Buddhism spread over the Indian subcontinent in the centuries following their beginning. They did not always spread to the same regions. The presence of Jainism in Tamil Nadu, for example, has been confirmed by epigraphic evidence from at least the $2^{\text {nd }}$ century BCE onward; ${ }^{326}$ Buddhists did not arrive in this region until much later. Buddhists, on the other hand, settled in other regions, prominent among these the region sometimes referred to as Greater Gandhāra, in the north-western parts of the subcontinent. Buddhist thought went through important developments in that region. It is here that Abhidharma thought was systematized, so as to give rise of Sarvāstivāda philosophy. Features of this philosophy, presumably the first systematic philosophy of the subcontinent, include the belief in the momentariness of all that exists, the idea that all existing things are in reality successions of entities (the so-called dharmas) that last no longer than a single moment; further the atomic nature of matter and its consequence that the objects of our ordinary experience are aggregates. We find these ideas also in the Śvetāmbara canon, and there are reasons to think that they had been borrowed from Sarvāstivāda Abhidharma. Even the word pudgala, which survives in Jainism but in a sense altogether different from the one it has everywhere else, appears to be based on the buddhist notion of pudgala ${ }^{327}$ For Buddhist scholasticism it designates the person conceived of as the totality of items (Buddhists would say dharmas) that constitute it. The use of pudgala in the Śvetāmbara canon shows a development from 'person' to 'material object' that is understandable if we take this development to start from the buddhist notion of pudgala. The fact that the buddhist pudgala and the soul as it came to be conceived of in Jainism share the all-important feature that they have a spatial dimension that coincides with that of the physical body points in the same direction: it has repeatedly been pointed out

\footnotetext{
${ }^{325}$ On the early influence of Jainism on Buddhism see, most recently Bronkhorst, 2009, part 1 .

${ }^{326}$ Mahadevan, 2003: $126 \mathrm{f}$.

${ }^{327}$ See Bronkhorst, 2000.
} 
by scholars that the oldest texts of the Śvetāmbara canon have an altogether different notion of the soul.

It seems, then, that the Jainism that finds expression in parts of the Śvetāmbara canon and in later texts has undergone a strong influence from scholastic Abhidharma Buddhism of the Sarvāstivāda variety. Sarvāstivāda philosophy began in Greater Gandhāra, presumably during the second century $\mathrm{BCE},{ }^{328}$ and appears to have remained confined to the Northwest for some centuries, with a strong branch in Kaśmīra. It produced there numerous texts, including the different Vibhāsās, and the Hrdaya treatises, culminating in the famous Abhidharmakośa and Bhāṣya of Vasubandhu and other works. ${ }^{329}$ The awareness of the main features of this philosophy already in the Sūyagada, one of the old texts of the Śvetāmbara canon, suggests that this influence took place at a relatively early date, presumably in north-western India. This, if true, would imply that Buddhism and Jainism exerted an influence on each other, in northwestern India, during the final centuries preceding the Common Era and the first ones following it.

This is indeed likely. Even though there is little evidence of a jaina presence in Greater Gandhāra during that period, ${ }^{330}$ Jainas were very much present in Mathurā from an early date onward. ${ }^{331}$ Indeed, it has been observed that "it is quite possible that the power of local traditions of the ancient holy site of Mathura themselves [sic] influenced and even shaped the development of Jain religiosity". ${ }^{332}$ Mathurā and Gandhāra became the two main centres of the Indian empire of the Kuṣānas during the first centuries of the Common Era. Given that there were also many Buddhists in Mathurā, there can be no doubt that the new

\footnotetext{
${ }^{328}$ See Bronkhorst, 2002; 2004: §§ 8-9.

${ }^{329}$ See Willemen, Dessein \& Cox, 1998.

${ }^{330}$ Gail (1994) draws attention to the presence of an Ardhaphālaka Jaina monk on a relief from Gandhāra.

${ }^{331}$ Dundas (2006: 405-406) mentions "the lack of any obvious early Jain presence in the Gandhāra region equivalent to that of Buddhism", and points out in a footnote (no. 47) that the cheda sūtras set Mathurā as the north-westerly limit for Śvetāmbara ascetic travel.

${ }^{332}$ Cort, 2010: 32, with a reference to Kendall Folkert.
} 
Sarvāstivāda philosophy was known there. ${ }^{333}$ It seems a safe bet to conclude that it was in Mathurā that the Jainas were confronted with these new ideas and used them to elaborate their own philosophical thought.

This idea is attractive for another reason as well. Mathurā is famous for the big jaina stūpa that has been discovered there. ${ }^{334}$ This is at first sight surprising, for Jainism is not primarily associated with stūpa worship. However, there are various historical sources that mention stūpas in connection with Jainism. ${ }^{335}$ There is a story in which the buddhist king Kanișka venerates by mistake a jaina stūpa. ${ }^{336}$ And Gregory Schopen (1996: 568 f.) refers to a passage in the early buddhist canon (Dīgha Nikāya and Majjhima Nikāya) in which mention is made of a thūpa (Skt. stūpa) in connection with Niganța Nātaputta, the 'founder' (or better, most recent Jina) of Jainism. Peter Flügel (2008; 2010a) has recently pointed out that relic-worship is not absent in modern Jainism, but clearly it does not play a prominent role. It seems as if there has been a discontinuity in the history of Jainism: before the break stūpa worship was part of regular worship, after the break it was played down or suppressed altogether.

Certain texts of the Śvetāmbara canon explain why the bodily remains of tīrthankkaras are not worshipped. They are not worshipped because they cannot be worshipped; they cannot be worshipped because they were taken away by the gods. ${ }^{337}$ We learn this from a passage in the Jambuddivvapannatti, a text contained in the Śvetāmbara canon, and an analysis of the passage concerned brings to light that the crucial paragraphs were added to a story that did not know about this divine intervention. In other words: the story of the removal of the bodily remains of the tirthankaras is a later addition to a text that itself is not particularly old.

\footnotetext{
${ }^{333}$ Damsteegt (1989: 299) is of the opinion "that the vocabulary of Buddhist inscriptions found at Mathurā shows a link with the North-West". Furthermore, "[i]n Jaina inscriptions from Mathurā one or two phrases can be pointed out which indicate a connection with the North-Western Buddhists or with Buddhists of Mathurā"' (ibid.). ${ }^{334}$ Smith, 1900.

${ }^{335}$ See Cort, 2010: 29 f.; 126 f.

${ }^{336}$ Lévi, 1896: 457-463, 477. Mistaken identity between Buddhists and others is a recurring theme during this period; see Schopen, 2007: $68 \mathrm{ff}$.

${ }^{337}$ In their stead icons were sometimes made to stand in for the relics; Cort, 2010: $126 \mathrm{f}$.
} 
Some editors saw fit to pull away the rug from underneath all forms of relic worship related to the tìrthankaras. ${ }^{338}$

This observation gains significance in light of the fact that the Buddhists appear to have done something similar yet different with regard to the bodily remains of the Buddha. Remember that the main surviving story as to the death of the Buddha is the point of departure of the relic worship that has characterized Buddhism in all of its forms through the ages: the remains of the incinerated body of the Buddha were distributed among a number of followers, each of whom did the necessary to pay homage to their shares. A sequel to the story recounts that Emperor Aśoka divided these remains further, so that there are in the end countless relics of the Buddha that the faithful can worship. In other words, the story of the death of the Buddha supports relic worship. ${ }^{339}$

An analysis of the sources suggests that this story is an invention that may not correspond to historical reality. Indeed, a variety of features of the story, as well as some texts that had not so far received the attention they deserve, suggest that the body of the Buddha may not have been incinerated and subsequently divided, but rather that this body was put, as it was, in one single stūpa. ${ }^{340}$ It appears therefore that Buddhism, at a rather early point in its history, may have adjusted some of its "historical" documents so as to suit the wishes of followers to worship the bodily remains of the Buddha.

Let us now return to Mathurā under the Kuṣānas. Buddhism was at this time a religion in which the cult of relics played a central role. Jainism, too, had some place for the cult of relics, but not quite as much as Buddhism. Moreover, the presence of both buddhist and jaina stūpas was a source of confusion, perhaps even of conflict, ${ }^{341}$ and we have already seen that there is a story according to which King Kaniṣka venerated by mistake a jaina stūpa. In this situation the need may have been felt to distinguish Jainism from Buddhism. The most obvious and

\footnotetext{
${ }^{338}$ See Appendix to chapter III.7, below.

${ }^{339}$ So Strong, 2007a.

${ }^{340}$ For details, see chapter III.7 ("What happened to the body of the Buddha?"), below.

${ }^{341}$ Quintanilla (2007: 252 n. 6) quotes the following passage from S. B. Deo: "The Vyavahāra Bhāsya refers to a Jewelled thūba (stūpa) at Mathurā, due to which ill-feeling spread between the Jainas and the Buddhists, which ultimately resulted in the defeat of the Buddhists. People at Mathurā were said to be devoted to Jina images which they installed in their houses."
} 
straightforward way to do so was to leave relic and stuppa worship to the Buddhists. One of the ways in which this could be accomplished was by providing additional information as to what happened to the bodily remains of tïrthankaras: they did not remain on earth and could not therefore be worshipped. Somehow this project succeeded, with the result with which we are familiar: stūpa worship plays only a minor role in Jainism, which profoundly distinguishes itself in this respect from Buddhism.

John Cort's recent book Framing the Jina (2010: 127) concludes a discussion with the following statement: "It may well be that the Jain stupa at Mathura is the sole remaining archaeological evidence of a wider practice of Jain relic worship that subsequently disappeared, for reasons that are equally unclear." Our discussion so far has come to the same conclusion, with this difference that we can propose a tentative answer to the question as to why jaina relic worship disappeared. To repeat it once more, this may have been due to the competition with Buddhism to which Jainism was exposed for a number of centuries in and around Mathurā, and to which Jainism responded by abandoning the cult of bodily relics and concentrating on other things.

If there was a discontinuity in the history of Jainism in Mathurā, we might hope that archaeological evidence could provide us with information that the surviving texts try to hide from us. One could argue that such evidence exists in the form of the so-called āyāgapațas ("large, intricately carved stone plaques") found in fairly large numbers in Mathurā. One researcher, Sonya Rhie Quintanilla (2000: 91 n. 47; quoted in Dundas, 2006: 386), claims that "[t]he earliest known Jaina texts significantly postdate most of the āyaggapațas by at least several hundred years". This can hardly be accepted in this form. But it seems likely that the surviving redaction of the Śvetāmbara canonical texts postdates these a ayagapatas, and we have seen that this surviving redaction may have adjusted matters here and there in accordance with newly felt needs. It is therefore very interesting and no doubt significant that some āyāgapațas from Mathurā depicts stūpas as their main central element (Quintanilla, 2000: 105). 
May we assume that these $\bar{a} y \bar{a} g a p a t ̦ a$ date back to a period when stūpas were still part of regular jaina religious life? ${ }^{342}$

The idea of a discontinuity in the history of Jainism is attractive for another reason as well. The strict vegetarianism of jaina monks is hard to reconcile with certain canonical passages that clearly speak about eating fish and meat. Suzoko Ohira (1994: 18-19) has tried to reconcile the two by proposing a break in the history of Jainism: "It is ... feasible to assume that the rigid vegetarianism of the present day Jainas commenced at ... a later time [than the time of composition of those canonical texts that speak of eating meat]" (p. 19). Ohira guesses that this break took place "most probably after the mass exodus of the Jainas from Mathurā to the South and West, where they were bound to impress the local people by their exemplary deeds". If we consider that the abandonment of relic worship may have been inspired by similar motives, there is no a priori reason to exclude that both are two sides of the same break.

Nor is there a priori reason to think that the break took place after the mass exodus of the Jainas from Mathurā. We know that in Mathurā itself a crisis situation forced the Jainas in subsequent years to reconstitute their textual tradition, and presumably also their other traditions. ${ }^{343}$ The crisis and the subsequent events are described in Jinadāsa's Nandī-cūrṇi, a text that dates from 676 CE. The passage concerned reads, in Wiles's translation (2006: 70-71):

It is said, there was a time of profound and difficult famine for twelve years, because [the ascetics] were again and again ... lapsing [from the rules] for the sake of food, scriptural learning (suta) perished through the absence of understanding (gahana), text-work (gunaṇa $)$, [and] anuppeha [?]. Then in the time of plentiful food in Mathurā there was a great meeting of ascetics with the faithful, headed by Ācārya Khandila, saying: Who remembers whatever [let him recount that for us].' Thus the Käliyasuta [texts] were gathered. Because this was done in Mathurā it is said to be the Mathurā recension. And that approved by the Ācārya Khandila was done in his presence and is said to be the mode of explanation....

Others say: that scriptural learning (suta) was not destroyed, but in that very difficult famine the other main bearers of the mode of

\footnotetext{
${ }^{342}$ Quintanilla dates the āyagapatas between the second century BCE and the third century CE.

${ }^{343}$ See Balbir, 2009.
} 
explanation perished. Only the teacher Khandila remained. In Mathurā the mode of explanation was again set forth for the ascetics, therefore it is called the Mathurā recension, the mode of explanation in his presence it is said.

This passage mentions no date, and Wiles points out that dates are not assigned to this event until many centuries later, and then only in tentative and qualified statements. In other words, we cannot derive much information from Jinadāsa's passage concerning the date of the great famine and the subsequent gathering of texts in Mathurā, except of course that these events must have taken place before $676 \mathrm{CE}$, the year in which the Nandī-cūrṇi was composed. ${ }^{344}$

However, this statement does make clear that there was a break in the tradition of Jainism in the area of Mathurā. It seems fair to assume that this break did not only concern the memorized scriptures, but Jainism in all its aspects, which had been calamitously shaken until its foundations. It makes sense to attribute the other discontinuities considered above to this same period, whatever may be its exact date.

The theory presented so far explains a number of otherwise obscure facts related to the Śvetāmbara canon. It explains not just why some of its texts are acquainted with Sarvāstivāda philosophy, but also why a number of them have themselves adopted positions from that philosophy; it explains why the word pudgala has acquired such an altogether unusual meaning in these texts, why Jainism has largely abandoned relic worship and how and why the story of the disappearance to heaven of the bodily remains of tìrthankaras found its way into this canon. It may even explain why the Jainas abandoned meat eating. But it also raises new questions.

Scholars tend to agree that it was under the Kuṣānas that the Buddhists from north-western India adopted Sanskrit as the language of their scriptures. ${ }^{345}$

\footnotetext{
${ }^{344}$ Wiles (2006) traces in detail the way in which most modern scholars have come to dates in the fifth or sixth century for the council, without sufficient justification in the texts.

${ }^{345}$ Not only the Buddhists. Apart from some few minor exceptions, "the earliest Sanskrit inscriptions are found in Mathurā, which has yielded several records of the first and second centuries A.D., that is, the time of the Śaka Kṣatrapas and the early Kuṣānas,
} 
New texts were henceforth written in Sanskrit, and many of the older texts were translated into Sanskrit. We have seen that this massive change from a Middle Indic language to Sanskrit appears to have been connected with Buddhism's dependence upon the brahmanized royal court. Those who depended upon royal support had to be able to plead their cause in Sanskrit. The Buddhists of northwestern India had realized that, and had therefore wholesale shifted to Sanskrit.

What about the Jainas of Mathurā? Dundas (1996: 147) has suggested "that the well documented Jain connection from around the second century BCE with the north-western city of Mathurā which was located in the region of $\bar{A}$ ryāvarta, the heartland of traditional brahman users of Sanskrit, may have effected some kind of gradual shift in Jain linguistic usage ..., which subsequently percolated into more outlying areas of Jain activity in the west and south". According to this position, which its author calls "difficult to prove", the adoption of Sanskrit by jaina authors began in or around Mathurā during the centuries surrounding the beginning of the Common Era.

This position is confronted with difficulties. To all appearances, the partial adoption of Sanskrit by Jainas took place much later, many centuries after the time of the Kuṣānas. ${ }^{346}$ The one exception appears to be the Tattvārtha Sūtra, which we will consider separately, below.

The authors and editors of the Śvetāmbara canon, then, were aware of philosophical developments outside the jaina community and even adopted some of them, but without adopting Sanskrit. To this observation a further one can be added. The Viyāhapannatti of the Śvetāmbara canon contains an early expression — in the story of Jamāli — of the position that came to be known by the name anekāntavāda. This position constitutes a solution to what Matilal has called "the

which are written in Sanskrit or a dialect very closely approaching it." (Salomon, 1998: 87). See further Salomon, 1998: 88: "The Sanskrit inscriptions from the earliest phase at Mathurā ... are mostly Brahmanical in affiliation. ... Moving on to the period of the Great Kuṣānas (i.e., Kaniṣka and his successors ...), we now find more Mathurā inscriptions in reasonably standard Sanskrit, including for the first time some of Buddhistic content."

${ }^{346}$ Note however that the fairly ornate structures of the Aupapātika Sütra and the Anuttaraupapātikadasāh Sūtra, involving regular compounding and long rhythmic sentences, might, according to Dundas (2006: 388), "be compared from a stylistic point of view with the famous inscription of $150 \mathrm{CE}$ of the satrap Rudradāman, whose Sanskrit prose is of a similar form and the apparent product of a nascent belles lettristic culture." 
paradox of causality": how can a pot be produced if there is no pot to begin with? There is no time at present to enter into the details of this paradox, ${ }^{347}$ and of the solution offered by the Jainas. ${ }^{348}$ It is however important to be aware that this paradox occupied the minds of all Indian philosophers - buddhist, brahmanical and jaina — roughly from the time of Nāgārjuna on. ${ }^{349}$ The fact that the Śvetāmbara canon presents a solution to this problem (disguised in the story of Jamāli) shows, once again, that its authors interacted with non-jaina thinkers. It shows however more. It shows that these jaina thinkers were ready to participate in the debate, propose a solution, without joining the other participants in choosing Sanskrit as vehicle of communication. Clearly, the Jainas were influenced by texts that were composed in Sanskrit without themselves adopting this language.

How do we explain that the Jainas of Mathurā could resist the adoption of Sanskrit where the Buddhists could not? To my knowledge, the texts provide no answer to this question. It may however be useful to recall the reason why the Buddhists of that part of the subcontinent had turned to Sanskrit: they depended upon royal support and had to plead their cause at court.

Jainism may have found itself in a different situation. We have already seen that the Jainas of Mathurā may no longer have supported the cult of stūpas. Within the Śvetāmbara community, moreover, there has been an ongoing debate for or against the temple-dwelling monks who were sedentary inhabitants of temples or of monasteries built beside temples. ${ }^{350}$ In the course of this debate, it appears, neither side won, or won for long. The Śvetāmbara community may distinguish itself in this respect from the Buddhists of North India, where monastic life succeeded in imposing itself, almost to the exclusion of monks who preferred to live without regular residence. This does not mean that the Jainas of Mathurā did not need support. To cite Dundas (2002: 114-115): “[D]onative inscriptions ... show that by the turn of the common era Jainism was patronised at Mathurā by people such as traders, artisans, jewellers and indeed courtesans: in

\footnotetext{
${ }^{347}$ See Bronkhorst, 1999.

${ }^{348}$ See Bronkhorst, 2003.

${ }^{349}$ On the date of Nāgārjuna, see Walser, 2002.

${ }^{350}$ Dundas, 2002: $136 \mathrm{ff}$.
} 
other words, the skilled and moneyed male and female middle classes from whom the lay community has usually, although not exclusively, been constituted. This bears clear witness to the fact that Jainism was not in its earliest period a purely ascetic religion and that the patterns of worship, devotion and practice which gradually emerged within it proved attractive to lay followers whose interaction with monks and nuns on a formal basis provided the means for the maintenance of the religion. ${ }^{, 351}$ It is tempting to think that the needs of these Jainas left them relatively independent of the royal court, allowing them to continue using Prakrit rather than Sanskrit.

This position appears to be supported by epigraphical evidence. Smita Sahgal observed in 1994: "[In North India, Jainism] not only ... existed in the period [from $200 \mathrm{BCE}$ to $300 \mathrm{CE}$ ], it actually flourished. It failed to catch the attention of the historians because unlike [Brahmanism and Buddhism] it did not receive state patronage (at least in north India), and hence is not mentioned in those sources connected with royal life." (p. 205-206; my emphasis, JB). Indeed, "none of the inscriptions found so far refer to donative land grants at this point of time. Unlike the Buddhists, the Jainas still did not acquire any land base. Jaina monks basically remained wanderers." (p. 226) ${ }^{352}$ Sahgal refers in this context to the Vyavahärasūtra, according to which "the Jaina monks should not cultivate links with king or people close to him and at the same time do nothing to incur his displeasure". ${ }^{353}$ Dundas (2002: 118) insists that "[t]he ancient texts which legislate for ascetic behaviour are adamant that it is improper for monks to take alms from a king", and refers in this connection to Vatțakera's Mülācāra and to Haribhadra on the Âvaśyakaniryukti. Dundas (2006) calls Jainism during its first eight centuries or so a "non-imperial religion", and supports this with the

\footnotetext{
${ }^{351}$ There were jaina temples and shrines in Mathurā "from perhaps as early as the second century BCE" (Cort, 2010: $30 \mathrm{f}$.).

${ }^{352}$ See further Sharma, 2001: 147: "There is no evidence that Jainism enjoyed the patronage of the Kușāna rulers. The credit for the popularity of Jainism at Mathurā during the Kuṣanna period goes to its splendid monastic organisation and the religious zeal and fervour of its adherents." Further Chanchreek \& Jain, 2005: 281: "There is nothing to show that Śaka or Kuṣāna kings themselves had any particular weakness for this religion."

${ }^{353}$ Reference to S. B. Deo, History of Jaina Monachism, p. 234, not accessible to me.
} 
observation that it seems to have been given only sporadic royal sponsorship ( $\mathrm{p}$. $385)^{354}$

Let us return to the Tattvārtha Sütra, presumably the oldest surviving jaina text composed in Sanskrit. R. Williams (1963: 2) has shown that this text is much closer to the Digambara śrāvakācāras than to the Śvetāmbara śrāvakācāras. An analysis of its doctrinal content, moreover, suggests that its author was a Yāpanīya. ${ }^{355}$ It is true that Padmanabh S. Jaini (1995) does not exclude that certain Kuṣāṇa sculptures from Mathurā depict Yāpanīya monks, Jaini is also definite about the Śvetāmbara, or rather proto-Śvetāmbara, affiliation of the Jainas of Mathurā (p. 311): 356 "The affiliation of what at a later time came to be designated as the Śvetāmbara sect with the region of Mathura is corroborated by the depiction on Mathura sculptures of their legend of the transfer of Mahāvīra's embryo by Harinegamesi as well as inscriptional evidence of certain ecclesiastical groups (gana, gaccha) traceable to the list of the Elders (sthavirāvalī) in the Śvetāmbara texts." The combination of Yāpanīya and Digambara features allows us to surmise, though not prove, that the Tattvärtha Sütra was composed in the South, presumably some time between 150 and 350 CE. In other words, this text may have been composed at the time of the Kuṣananas, but not in their realm. There is an early Śvetāmbara commentary on it, the Tattvārthādhigama Bhāṣy, composed in Pātaliputra, presumably before $450 \mathrm{CE}$; Pātaliputra, too, is far from Mathurā. Then there is the Sarvārthasiddhi, a Digambara commentary by Devanandin, apparently composed soon after the beginning of Skanda Gupta's reign, i.e. not long after 455 CE. ${ }^{357}$ Apart from these, there are not many surviving jaina Sanskrit texts from before $500 \mathrm{CE}$.

\footnotetext{
${ }^{354}$ See further Dundas, 2006: 391: “[E]arly evidence of regular Jain patronage by royal houses, while not nonexistent, is sketchy. Revealingly, there are no depictions of tìrtankaras on royal coinage, even that of the religiously highly pluralistic Kushanas, and no substantial evidence of royal land grants to the Jain community ... Early Jain images ... lack royal insignia, such as the parasol, which occur only at a later date ..."

${ }^{355}$ Bronkhorst, 1985.

${ }^{356}$ See Quintanilla, 2000: 105-106 n. 67; 2007: 250-252, for further information and references on these so-called Ardhaphālaka Jainas.

${ }^{357}$ Bronkhorst, 1985.
} 
Judging by this evidence thus interpreted, Mathurā plays no role in the introduction of Sanskrit into Jainism.

The contents of the Tattvārtha Sütra are not completely independent of the developments that affected the Śvetāmbara canon. Some of the buddhist scholastic influence we identified in the Śvetāmbara canon has also affected this text: the atomic nature of all that exists, including time and space, and the peculiar use of the term pudgala. The anekāntavāda, on the other hand, is not clearly present in the Tattvārtha Sūtra (even though commentators introduce it). All this suggests that the Tattvārtha Sūtra was composed before the Śvetāmbara canon had reached its present shape.

If we stick to the idea that the Tattvārtha Sūtra was composed in South India, we are entitled to speculate about the reason why Jainism presumably started using Sanskrit there rather than in the region near the brahmanical heartland. It suggests that the Jainas in southern India, and the Digambaras in particular, had a different relationship to the royal courts than the Jainas of Mathurā. To put it more precisely: presumably the southern Jainas were more dependent upon the royal courts than the Jainas of Mathurā. Interestingly, there are indications that suggest that the southern Jainas were in the possession of more "property" than their coreligionists in the north. This property included caves $^{358}$ and monasteries accompanied by substantial land endowments. ${ }^{359}$ Sources from the fifth century CE accuse certain monks of having virtually abandoned mendicancy and taken to a settled mode of life, tilling the ground and selling the produce. ${ }^{360}$ These developments led to the emergence of the bhatt $\leq$ raka, whom Dundas (2002: 123) calls "the pivotal figure in medieval Digambara Jainism". If we assume that these conditions prevailed when the Tattvārtha Sūtra was composed, they may have been to at least some extent responsible for the use of Sanskrit in this text. The author of the Tattvārtha Sütra and his southern coreligionists needed royal support, and needed to be ready to

\footnotetext{
${ }^{358}$ The inscriptions from Tamil Nadu recorded by Mahadevan (2003: 162), some of which date to a time well before the beginning of the Common Era, were for a large part associated with jaina caves.

${ }^{359}$ Dundas, 2002: 123.

${ }^{360}$ Dundas, 2002: 122.
} 
present the fundamental doctrines of their religion in the only language acceptable at the brahmanized courts: Sanskrit.

These reflections about the Tattvārtha Sūtra and the reasons behind its choice of language are speculative. But also the other observations that I have proposed raise a number of questions, most of which require further study. I have suggested that Śvetāmbara Jainism has been profoundly influenced during its formative period by Buddhism of the Sarvāstivāda variety, much less by Brahmanism. Apparently it felt the need to distinguish itself from Buddhism, and the interruption of a stūpa cult may be an outcome of this. There was less competition with Brahmanism, because Śvetāmbara Jainism had much less to do with the royal court than Buddhism, and it was at the royal courts that Brahmanism had become successful at the time. Śvetāmbara Jainism had less to do with royal courts, because its monks and nuns lived, more than the Buddhists, the lives of mendicants and had no (or fewer) monasteries and caves to maintain. The situation in the south was different. For reasons that cannot be explored here, the southern Jainas had come into the possession of caves and monasteries. As a result they depended on handouts from above, and therefore on royal support. They had to be represented at the courts, so that they had to give in to using Sanskrit where the Śvetāmbaras had not felt this need.

It bears repeating that many of these claims can be questioned, and perhaps even proved wrong. But even if proved wrong, these discarded claims may yet contribute to a fuller and better understanding of the history of Jainism. 


\section{III.4 Buddhist Hybrid Sanskrit, the original language}

The buddhist adoption of Sanskrit may initially have been no more than a matter of convenience: the Buddhists of northwestern India needed Sanskrit to defend their interests. However, Sanskrit is not the kind of language that is easily adopted for mere convenience. It was the sacred language of Brahmanism, and as such treated as more than an ordinary language. Buddhism did not take long to start doing the same.

Languages in which the sacred texts of religious traditions have been composed and preserved tend to be looked upon as more than ordinary languages. This is not only true of India. Hebrew has been considered the original language by Christians and Jews alike. ${ }^{361}$ This view, which in the case of the Jews is already attested before the beginning of our era, for the Christians of course somewhat later, survived right into the 19 th century. ${ }^{362}$ A similar view was held by at least some Moslems with respect to Arabic, the language of the Koran and therefore of Allah himself, this in spite of the fact that the composition of the Koran can be dated very precisely in historical and relatively recent times. ${ }^{363}$

In India the followers of the vedic tradition have always kept Sanskrit, the language of the Veda, in high regard. Sanskrit is the only correct language, other languages being incorrect. Patañjali's Vyākaraṇa-Mahābhāṣya (ca. 150 BCE), in its first chapter called Paspaśāhnika, distinguishes clearly between correct and incorrect words, pointing out that many incorrect words correspond to each correct word; besides correct gauh there are many incorrect synonyms: $g \bar{a} v \bar{\imath}$, goṇi, gotā, gopotalika $\bar{a}$, etc. There are various reasons for using correct words only, the most important being that this produces virtue (dharma) and benefit (abhyudaya). Correct words are in fact used in many texts and regions; Patañjali mentions the earth with its seven continents and the three worlds, which shows that for him Sanskrit is the language of the universe. Sanskrit is also eternal. The

\footnotetext{
${ }^{361}$ Borst, 1957-63: $147 \mathrm{f}$. etc. (for an enumeration of the pages dealing with the subject see p. 1946 n. 204); Scholem, 1957: 19, 146; Katz, 1982: 43-88.

${ }^{362}$ Borst, 1957-63: 1696; see also Olender, 1989.

${ }^{363}$ Mounin, 1985: 117; Borst, 1957-63: 337 f., 352 f.; Kopf, 1956: 55 f.; Loucel, 1963-64.
} 
reasons adduced to prove this may seem primitive to us, but they leave no doubt as to Patañjali's convictions. Someone who needs a pot, he points out, goes to a potter and has one made; someone who needs words, on the other hand, does not go to a grammarian to have them made. ${ }^{364}$ Some later authors refer to Sanskrit as the language of the gods (daivī vāk). Among them is Bhartrhari's Vākyapadīya (Vkp 1.182), who adds that this divine language has been corrupted by incompetent speakers. ${ }^{365}$ The Mīmāmsakas and others, too, claim that the vedic texts, and therefore also their language, are eternal. I limit myself here to a quotation from Kumārila Bhața's Ślokavārttika, which states: ${ }^{366}$ "For us the word go ('cow') is eternal; and people have an idea of the cow from such vulgar deformations of it as $g \bar{a} v \bar{\imath}$, etc., only when it follows the original [correct] word ( $\mathrm{go}$ ); and such comprehension is due to the incapability [of the speaker to utter ... the original correct form of the word]." The example is the same as the one given by Patañjali, but Kumārila adds a dimension which we do not find in the Mahābhāsya: the original word is $g o$, and $g \bar{a} v \bar{l}$ is nothing more than a corruption of it. ${ }^{367}$ Helārāja, commenting on Vākyapadīya 3.3.30, is even more explicit when he states that in an earlier era (purākalpe) language was free from corruptions. ${ }^{368}$ He follows here the ancient Vrtti on Vākyapadīya $1.182(146) .{ }^{369}$ [The much later author Annambhața, interestingly, holds the view that not only Sanskrit, but also other languages - like that of the Yavanas — were created by God in the beginning. $]^{370}$

\footnotetext{
${ }^{364} \mathrm{Cp}$. Ibn Fāris' remark: "Il ne nous est point parvenu que quelque tribu arabe, dans une époque proche de la nôtre, se soit mise d'accord pour désigner quelque objet que ce soit, en formant une convention à son sujet." (tr. Loucel, 1963-64: II: 257).

${ }^{365}$ A closely similar observation occurs in Bhartrhari's commentary on the Mahābhāsya ('Dīpikā'), Āhnika I p. 161.29 - p. 17 1. 1: anye manyantel iyam daivī vāk/sā tu purușāśakter ālasyād vā prakīrṇā/. See also Tripathi, 1986: 88.

${ }^{366}$ ŚlV, Śabdanityatādhikarana, 276: gośabde 'vasthite 'smākam tadaśaktijakāritā/ gāvyāder api gobuddhir mūlaśabdānusārin̄ī// Tr. Jha.

${ }^{367}$ Kumārila does not exclude the possibility that certain words, which are not (no longer?) in use among the Āryas because the objects designated are not familiar to them, survive among the Mlecchas; see Tantravārttika on 1.3.10.

${ }^{368}$ Ed. Iyer p. 143 1. 14: purākalpe 'nrtādibhir ivāpabhraṃśair api rahitā vāg āsīd ...

${ }^{369}$ Ed. Iyer p. 233-34: purākalpe svaśarīrajyotișām manuṣyānām yathaivānṛtādibhir

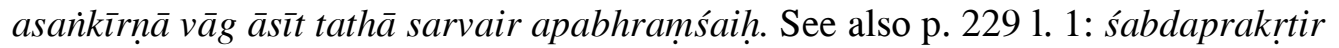
apabhramśah, and Iyer, 1964.

${ }^{370}$ See Uddyotana I p. 90-91: vastuta īśvareṇa ș̣̦ṭāāov arthaviśeṣavat śabdaviśeșā api sṛ̦țā eva .../ na hi tadānīm samskrṭtam eva srṣțam na bhāṣāntaram ity atra mānam asti,
} 
Brahmanism continued to use the language of its sacred texts. The same is true of Theravāda Buddhism, whose sacred language, at present known by the name Pāli, is called Māgadh̄̄ by the Buddhists themselves. ${ }^{371}$ Māgadhī, we read in Buddhaghosa's Visuddhimagga, is the original language (mūlabhāsā) of all living beings, the natural form of expression (sabhāvanirutti). ${ }^{372}$ The Sammohavinodinī, commentary to the Vibhanga of the Abhidhammapitaka, ascribes the following opinion to a monk called Tissadatta: ${ }^{373}$ "[Suppose] the mother is a Damilī, the father an Andhaka. Their [newly] born child, if it hears first the speech of the mother, it will speak the language of the Damilas. If it hears first the speech of the father, it will speak the language of the Andhakas. But if it doesn't hear the speech of either of them, it will speak the language of the Māgadhas. Also someone who is born in a big jungle, devoid of villages, where no one else speaks, he too will by his own nature start to produce words and speak this same language of the Māgadhas. ${ }^{374}$ In hell, among the animals, in the realm of ghosts, in the world of men and in the world of gods, everywhere this same language of the Māgadhas is

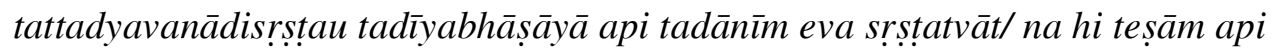
prathamạ̣ saṃskrtenaiva vyavahāraḥ paścād apabhraṃśarūpabhāṣāpravrttir iti kalpanāyām mānam asti/. Kamalākara Bhața, a scholar more recent than Annaṃbhața, holds on to the view that only Sanskrit words are expressive and eternal; see Pollock, 2001: 29.

${ }^{371}$ Hinüber, 1977; 1986: 20.

${ }^{372}$ Vism p. 373 1. 30-31; see also Saddanīti p. 632 1. 4.

${ }^{373}$ Vibh-a p. 3871.29 - p. 388 1. 7: mātā damil̄ mātu katham paṭhamạ̣ suṇāti damilabhāsam bhāsissati/ sace pitu katham paṭhamạ̣ suṇāti andhakabhāsam bhāsissati/ ubhinnam pi pana katham asunanto māgadhabhāsam bhāsissati/ yo pi agāmake mahāaraññe nibbatto tattha añño kathento nāma natthi so pi attano dhammatāya vacanam samuțthāpento māgadhabhāsam eva bhāsissati/ niraye tiracchānayoniyam pettivisaye manussaloke devaloke ti sabbattha mägadhabhāsā va ussannā/ tattha sesā otțakirātaandhakayonakadamilabhāsādikā ațthārasa bhās $\bar{a}$ parivattanti/ ayam ev' ekā yathābhuccabrahmavohāraariyavohārasaṃhatā māgadhabhāsā va na parivattatil. Cf. Hinüber, 1977: 239 f. Similarly Patis-a I, p. 5, 1. 27 ff. My wife, Joy Manné, drew my attention to this passage.

${ }^{374}$ The idea that children who grow up without others will speak the original language is not unknown to the West; see Borst, 1957-63: 800, 870, 1050, etc. Experiments were carried out in order to identify the original language; Borst, 1957-63: 39 (Psammetichus, cf. Katz, 1982: 54), 756 (Frederick II), 1010-11 (Jacob IV, 1473-1513), etc. (See p. 1942 n. 191 for further cases.) In India the Mughal Emperor Akbar tried a similar experiment, apparently without success, judging by what the English traveller Peter Mundy tells us about it: "Within 3 Course of Fatehpur there is a ruinated building, named Gonga Mohol, that is the 'house of the dumb', built by King Akbar of purpose, where hee caused little children to be brought up by dumb Nurses to know what language they would naturally speak, but it is sayd that in a long time they spake nothing at all." (Fisher 2007, 78). 
preponderant. The remaining eighteen languages - Oț̣a, Kirāta, Andhaka, Yonaka, Damila, etc. - undergo change in these [realms]. Only this language of the Māgadhas, rightly called language of Brahma and aryan language, does not change." The Mohavicchedani, which dates from the 12th - 13th century, goes to the extent of stating that all other languages are derived from Māgadhī: ${ }^{375}$ "It (i.e., Māgadhī) was first predominant in the hells and in the world of men and that of the gods. And afterwards the regional languages such as Andhaka, Yonaka, Damila, etc., as well as the eighteen great languages, Sanskrit, etc., arose out of it."

The Theravāda Buddhists considered Māgadhī, i.e. Pāli, the original language of all living beings. Not surprisingly, the Jainas reserved this privilege for the language of their sacred texts, viz. Ardha-Māgadhī. This position finds already expression in the Ardha-Māgadhī canon. The Aupapātika Sūtra (56) states: ${ }^{376}$ "With a voice that extends over a yojana, Lord Mahāvīra speaks in the ArdhaMāgadhī language, a speech which is in accordance with all languages. That Ardha-Māgadhī language changes into the own language of all those, both āryas and non-āryas." The Viyāhapaṇnati adds that "the gods speak Ardha-Māgadh̄̄". ${ }^{377}$ We find the same position repeated in a work by a jaina author of the 11th century, Namisādhu. Interestingly, Namisādhu writes in Sanskrit, no longer in Prakrit. His commentary on Rudrața's Kāvyālaṃkāra 2.12 contains the following explanation of the word prākrta: ${ }^{378}$ "'Prākrta': The natural function of language,

\footnotetext{
${ }^{375}$ Mohavicchedanī p. 1861.14 f., cited in Hinüber, 1977: 241: sā (sc. Māgadhī) va apāyesu manusse devaloke c'eva pațhamam ussannā/ pacchā ca tato andhakayonakadamil̄ādi-desabhāsā c'eva sakkațādiațthārasamahābhāsā ca nibattā/. ${ }^{376}$ bhagavam mahāvīre ... savvabhāsānugāmiṇīe sarassā̄e joyanan̄̄hāriṇa sareṇam addhamāgahāe bhāsāe bhāsai ... sā vi ya ṇam addhamāgahā bhāsā tesim savvesim āriyamaṇāriyānam appaṇo sabhāsāe pariṇāmeṇam parịnamai. Leumann, 1883: 61; cited in Norman, 1976: 17; 1980: 66. Similar remarks at Samavāya 34; Viy (ed. Nathamal) 9.33.149.

${ }^{377}$ Viy 5.4.24: devā ṇam addhamāgahāe bhāsāe bhāsaṃti. Cf. Deleu, 1970: 108.

${ }^{378}$ Namisādhu p. 31; cited in Nitti-Dolci, 1938: 159: prākrtteti/ sakalajagajjantūnām vyākaraṇādibhir anāhitasamskāraḥ sahajo vacanavyāpārah prakrtih/ tatra bhavam saiva vā prākrtam/ 'ārisavayane siddham devānam addhamāgahā bān̄' ityādivacanād vā prāk pūrvam krtạn prākrtam bālamahilādisubodham sakalabhāṣānibandhanabhūtam vacanam ucyatel meghanirmuktajalam ivaikasvarūpam tad eva ca deśaviśeșāt sạ̣skārakaraṇāc ca
} 
common to all men of this world and not beautified by [the rules of] grammar etc., this is the basis (prakrti). That which is in this [basis], or that [basis] itself is [called] Präkrta. ${ }^{379}$ Alternatively, Prākrta is prāk krta 'what has been made before' on the basis of the statement 'it has been established in the jaina canon (ārșavacana, lit. words of the rșis) that Ardha-Māgadhī is the speech of the gods' and other statements. [Prakrit] is said to be a language easy to understand for children and women, the origin of all languages. Like the water released by a cloud, it has but one form, yet, once differences have entered because of the difference between regions and because of beautification, it acquires the later distinctions between Sanskrit and the other languages. This is why the author of our treatise (i.e. Rudrata) has mentioned Prakrit at the beginning, and after that Sanskrit etc." We see that Namisādhu goes to the extent of considering ArdhaMāgadhī the predecessor of Sanskrit, from which the latter has been derived. It is also clear from this passage that Namisādhu, who wrote in Sanskrit, took this idea from his sacred texts, which themselves were still composed in Ardha-Māgadhī.

We have seen that both the Theravāda Buddhists and the Jainas believed that the language of their sacred texts was the original language of all living beings. Both went to the extent of claiming that also Sanskrit had descended from their respective original languages. This is not particularly surprising in the case of the Theravādins, who went on using their original language. The Jainas, on the other hand, shifted to Sanskrit. Potentially this was embarrassing for them. For by doing so they abandoned their original language, in order to turn to the very language which the rival Brahmins claimed to be original and eternal.

The example of Namisādhu shows that the later Jainas based their conviction on statements dating from the time when Ardha-Māgadhī was still in use. This is of interest because the Jainas who used Sanskrit were in a position closely similar to that of those Buddhists who used Sanskrit but whose sacred texts were, at least partly, in Hybrid Sanskrit. A crucial difference, however, is

samāsāditaviśeșạ̣ sat saṃskṛtādyuttaravibhedān āpnoti/ ata eva śāstrakrtā prākrtam ādau nirdiṣtam/ tadanu samskrțādīni/

${ }^{379}$ A similar argument is found in the Vrtti on Bhartrhhari's Vākyapadīya, and in the latter's Mahābhāsyadīpikā; see below. 
that, to my knowledge, no Hybrid Sanskrit text claims to be composed in the original language of all living beings.

Before we consider the question how the Buddhists explained the use of Hybrid Sanskrit in their sacred texts, we must return once more to the language of the Veda. I stated earlier that the Brahmins continued to use the language of the Veda, but this is of course not completely true. Vedic differs in various respects from the classical language, and indeed much of vedic literature did not fail to become unintelligible even to speakers of Sanskrit. This problem was already acute in the time of Yāska, one of the aims of whose Nirukta is precisely to find the meaning of unknown vedic words. We also know that already Pānini, who may antedate Yāska, gives an incomplete analysis of the Vedic verb. Both the vedic Brahmins and the Buddhists whose sacred texts were in Hybrid Sanskrit found themselves therefore in closely similar situations. Both of them used classical Sanskrit, whereas their sacred texts had been preserved in languages that, though related to classical Sanskrit, were in many respects different from it.

The vedic Brahmins solved this problem by denying its existence. This is particularly clear from the well-known refutation of Kautsa in the Nirukta (1.1516). Kautsa claimed that the vedic mantras have no meaning. Among the reasons he adduces the most important one for our purposes is that they are unintelligible. ${ }^{380}$ To illustrate this Kautsa cites a number of obscure Vedic forms. Yāska's reply is categorical: ${ }^{381}$ "It is no deficiency of the post that a blind man does not see it; the deficiency lies with the man." Vedic is therefore a form of Sanskrit that uses words and verbal forms that are not in common use in classical Sanskrit; that is not however the fault of the Vedic language, but rather of the person who is content not to employ those forms. For essentially, the words of Vedic and of classical Sanskrit are identical. ${ }^{382}$

A similar discussion occurs in the Mìmāmsā Sūtra and Śābara Bhāṣya. ${ }^{383}$ Here too we are assured that the sentence-meaning in Vedic is no different from

\footnotetext{
${ }^{380}$ Nir 1.15: athāpy avispaștārthā bhavanti.

${ }^{381}$ Nir 1.16: yatho etad avispaștārthā bhavantīti naișa sthānor aparādho yad enam andho na paśyati purușāparādhạ sa bhavati.

${ }^{382}$ Nir 1.16: arthavantah śabdasāmānyāt.

${ }^{383} \mathrm{MīS} 1.2 .31-45$ (31-53); pp. 48-69 in the Ānandāśrama edition, pp. 74-86 in Jha's translation.
} 
classical Sanskrit, ${ }^{384}$ and that "the meaning is there; only there is ignorance of it". ${ }^{385}$ The repetition of this discussion in the basic work of Mīmāmsāa shows how important it was for Brahmanism to emphasize the continuity - or rather: essential identity - between Vedic and classical Sanskrit. Because the two are identical, there is no need to state that one of them is the original, eternal language, and the other a development of the former. In fact, both are original and eternal, because they together constitute one and the same language. (This explains how Yāska's Nirukta (2.2) can derive Vedic primary nouns from classical verbal roots, and classical nouns from Vedic roots.)

The situation of the vedic Brahmins was in many respects parallel to that of those Buddhists who used Sanskrit but preserved sacred texts in Hybrid Sanskrit. And the solution accepted by the Brahmins would do equally well in the case of the Buddhists. They could simply deny that Hybrid Sanskrit is a different language, and maintain that it is essentially identical with classical Sanskrit, just like Vedic. There are some indications that this is indeed the solution that was chosen by at least some Buddhists. We consider first one of the surviving buddhist Sanskrit grammars.

A number of such grammars have come down to us. ${ }^{386}$ Generally they make no mention of Hybrid Sanskrit, and confine themselves to describing the classical language. The only exception appears to be the Kaumāralāta, called after its author Kumāralāta. This grammar is the first buddhist Sanskrit grammar we know of, and only some fragments of it, found in Turkestan, have survived. Fortunately these fragments allow us to observe, with Scharfe (1977: 162): "Just as Pānini has special rules for Vedic forms, Kumāralāta makes allowances for peculiar forms of the buddhist scriptures that resulted from their transposition into Sanskrit from Middle Indo-Aryan dialects (e.g. bhāveti for bhāvayati,

${ }^{384}{ }^{\mathrm{MīS}}$ 1.2.32 (siddhānta)/40: aviśiștas tu vākyārthah. Cp. also MīS 1.3.30 prayogacodanābhāvād arthaikatvam avibhāgāt, which Clooney (1990: 133) translates: "(A word used in ordinary and vedic contexts) has the same meaning in both, because they are not differentiated; for there are no (special) injunctions in regard to the usage (prayoga) of words." Biardeau (1964: 84) translates the first compound of this sūtra: "(Sinon), il n'y aurait pas d'injonction de quelque chose à faire."

${ }^{385}$ MīS 1.2.41/49: satah param avijñānam. Tr. Jha.

${ }^{386}$ See Scharfe, 1977: $162 \mathrm{ff}$. 
bhesyati for bhavisyati and elisions of final -am/-iṃ). The name used for these forms [is] ārṣa 'belonging to the rṣi-s,' [...]"387

Pānini's grammar uses once (1.1.16) the word anārșa, in the sense avaidika 'non-Vedic' according to the interpretation of the Kāsik $\bar{a} .{ }^{388}$ Kumāralāta's use of ārșa suggests therefore that he looked upon Hybrid Sanskrit as on a par with Vedic. And just as Vedic is not considered another language than classical Sanskrit by the Brahmins, one might think that Kumāralāta looked upon Hybrid Sanskrit as essentially the same language as classical Sanskrit.

Here, however, we have to be circumspect. The Jainas, too, use the term $\bar{a} r s ̣ a$ to refer to their sacred language, which is Ardha-Māgadhī. But the Jainas do not think that Ardha-Māgadhī is a form of Sanskrit, in their opinion it is the source of Sanskrit. ${ }^{389}$ All this we have seen. For the position of the Buddhists with regard to Hybrid Sanskrit we need, therefore, further evidence.

Unfortunately none of the other surviving buddhist Sanskrit grammars deal with Hybrid Sanskrit, nor indeed with Vedic. It is possible that the Cāndra Vyākaraṇa once had an Adhyāya dealing with Vedic forms. ${ }^{390}$ None of it has however been preserved, so that it is not possible to see whether these rules were used to explain Hybrid Sanskrit forms.

There is however a passage in Candrakīrti's commentary on Āryadeva's Catuhśataka which can throw further light upon our question. The commentary

\footnotetext{
${ }^{387}$ For details, see Lüders, 1930: 686, 693-95. See also Ruegg, 1986: 597. Lüders (1930: 532) sees a contrast between Buddhist Hybrid Sanskrit and Vedic ("Dem Veda wird das Wort des Meisters und seiner Jünger entgegengestellt, und es wird für dieses dieselbe Autorität beansprucht wie für den Veda."), but some of the evidence to be considered suggests that the two were rather identified, at least by some Buddhists. Ruegg (2008: 11-12) refers to "the tradition - preserved in the bsTan 'gyur as well as by Bu ston and

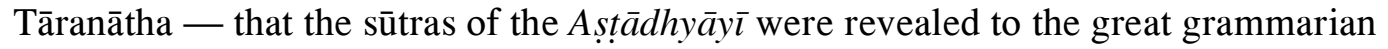
Pāninini by Lokeśvara ('Jig rten dban phyug, i.e. Avalokiteśvara), a brahmanical tradition being rather that Pānini received this revelation from Śiva." This too may be taken to lend support to the idea of an identity of Vedic and Buddhist Hybrid Sanskrit.

${ }^{388}$ P. 1.1.16: sambuddhau śākalyasyetāv anārșe. The Kāśikā explains: ot iti vartatel sambuddhinimitto ya okāraḥ sa śākalyasya ācāryasya matena pragṛhyasañjño bhavati itiśabde anārșe avaidike paratah/vāyo iti vāyav iti/bhāno iti bhānav iti/ etc.

${ }^{389}$ This is not necessarily true of all Jainas. Hemacandra, who uses the term $\bar{a} r s \underline{a}$ and describes the language concerned, does not appear to give evidence that he looked upon this language as the source of Sanskrit (unless his use of poranna 'old' in connection with this language (IV.287; see Hoernle, 1880: xviii f.) shows the opposite). Cf. Ghosal, 1969. ${ }^{390}$ See Oberlies, 1989: 2-3.
} 
survives only in Tibetan translation, which has been edited, studied and translated into English by Tom J. F. Tillemans.

Candrakīrti cites, under kārikā 278 of the Catuhśataka, a verse which has been preserved in its original form in the Samādhirāja Sūtra (9.26) as well as in Candrakīrti's own Prasannapadā (on Mūlamadhyamakakārikā 25.3) where it is cited, too. The verse reads: ${ }^{391}$

$$
\begin{aligned}
& \text { nivrrtti }{ }^{392} \text { dharmāna na asti dharmā } \\
& \text { ye neha }{ }^{393} \text { astī na te jātu asti/ } \\
& \text { astīti nāstīti ca kalpanāvatām } \\
& \text { evam carantāna na duḥkha śāmyatil/ }
\end{aligned}
$$

This means:

In extinction dharmas are without dharmas. Whatever is inexistent in this [state] does not exist at all. For those who imagine 'existence' and 'inexistence' and practise accordingly, suffering will not cease. ${ }^{394}$

Note that this verse is not written in classical Sanskrit. In the Prasannapada this fact is not so much as hinted at. In his commentary on the Catuhśataka, on the other hand, Candrakīti makes two grammatical remarks. The first one reads, in translation: ${ }^{395}$ "Here (i.e., in the words nivrtti dharmāna na asti dharmā) the seventh case-ending (i.e., of the locative) does not appear [in nivrtti], in accordance with the sütra: 'for sup, [substitute] $s u, l u k$, etc.'"

The sūtra to which Candrakīrti refers is P. 7.1.39: supām sulukpūrvasavarṇāccheyāḍādyāyājālah. This, however, is a Vedic sūtra! The preceding rule contains the term chandasi, and the phenomena described by 39 itself leave no room for doubt as to their Vedic nature. Candrakīrti apparently

\footnotetext{
${ }^{391}$ In Tibetan (Tillemans, 1990: II: 8): mya ngan 'das la chos rnams chos yod min/ 'di na gang med de dag gzhar yang med// yod dang med ces rtog pa dang ldan zhing/ de ltar spyod rnams sdugs bnga/ zhi mi 'gyurl/

${ }^{392}$ The Prasannapadā has nirvrtti.

${ }^{393}$ This reading agrees with the Prasannapada and with the Tibetan. The Samādhirāja Sütra has yeneti nāsti. See further Tillemans, 1990: II: 9 n. 1.

${ }^{394}$ Tr. Tillemans, 1990: I: 117.

395 Tillemans, 1990: II: 8: 'dir "sup rnams kyi su mi mngon par byas so" zhes bya ba la sogs ba'i mdor byas pa bdun pa mi mngon par byas pa'o. For the translation, cf.

Tillemans, 1990: I: 118, 235-36 n. 154.
} 
feels no hesitation to explain a Hybrid Sanskrit form with a Vedic rule of the Aștāadhyāȳ

Candrakīrti's second grammatical remark confirms this impression. It concerns the singular na asti, where we would expect na santi. Here Candrakīrti notes: ${ }^{396}$ "Correctly speaking one would say na santi (Tib. rnams yod min). But in accordance with the rule to the effect that 'it should be stated that verbal endings (tin) are [substituted] for [other] verbal endings', [the verse] says na asti dharma (Tib. chos yod min)." The rule here invoked can be identified as a line from the Mahābhāṣya on the same Pāṇinian sūtra 7.1.39. This line reads: tināạn ca tiño bhavantīti vaktavayam, ${ }^{397}$ and concerns, again, Vedic forms.

The above passages support the view that at least some Buddhists held the opinion that Buddhist Hybrid Sanskrit was not really a different language from classical Sanskrit. We must now consider a passage in Bhartṛhari’s Vākyapadīya which may indicate the opposite for certain other Buddhists. We have already had an occasion to refer to verse 1.182 of this text, according to the first half of which the divine language — i.e., Sanskrit — has been corrupted by incompetent speakers. The second half of the verse contrasts this view with another one: ${ }^{398}$ "The upholders of impermanence, on the other hand, hold the opposite view with regard to this doctrine." The precise meaning of "upholders of impermanence' (anityadarśin) is not specified, but it is at least conceivable that Buddhists are meant; the Buddhists, after all, considered impermanence one of their key doctrines, and used this very term anitya to refer to it. The point of view adopted by these upholders of impermanence is less problematic: they apparently believed that the so-called 'corrupt language', rather than deriving from Sanskrit, was the source of the latter. This is indeed how the ancient Vrtti understands the line, for it explains: ${ }^{399}$ "The upholders of impermanence, on the other hand, [...] say that Prakrit constitutes the collection of correct words, [because Prākrta means] 'that

\footnotetext{
${ }^{396}$ Tillemans, 1990: II: 10: legs par bshad pa las ni rnams yod min zhes bya bar 'gyur mod kyi "tingām ni ting ngor gyur ro zhes bya ba brjod par bya'o" zhes bya ba'i mtshan nyid las na chos yod min zhes gsungs so. Cf. Tillemans, 1990: I: 118, 236 n. 158.

${ }^{397}$ Mahā-bh III p. 256 1. 14.

${ }^{398}$ VP 1.182cd: anityadarśinām tv asmin vāde buddhiviparyayah.

${ }^{399}$ Vrtti on VP 1.182 [146], ed. Iyer p. 234: anityavädinas tu ... prakrtau bhavam prākṛtạ̣ sādhūnām śabdānām samūham ācakșate/ vikāras tu paścād vyavasthāpitah, yah saṃbhinnabuddhibhih puruṣaih svarasaṃskārādibhir nirṇīyate iti//
} 
which is in the basis' (prakrtau bhava). But later on a modification has been established which is fixed by men of impaired understanding, by means of accents and other refinements (samskāra)." The 'modification' here mentioned, which is characterized by accents and other refinements, is, of course, Sanskrit.

This passage from the Vrtti contains points of similarity with Namisādhu's defence of Prakrit studied above. This suggests that the Vrtti refers here to Jainas rather than to Buddhists. Does this indicate that also the Vākyapadīya refers to Jainas, and not to Buddhists?

Here several points have to be considered. First of all, it is more than likely that the author of the Vrtti is different from the author of the verses explained in it. ${ }^{400}$ Equally important is the fact that the Vākyapadīya never uses the word prākrta to refer to a language different from Sanskrit. Bhartrihari does mention the term in this sense in his commentary on the Mahābhāsya, but there in the context of 'some' who hold that Prakrit words are eternal. ${ }^{401}$ The 'some' here referred to can hardly be the 'upholders of impermanence'. ${ }^{402}$ Add to this that all the three passages considered from the Mahābhāsyadīpikā, from the Vrtti and from Namisādhu's commentary mention the same grammatical explanation (prākrta $=$ prakrtau bhava $)$ and it is tempting to conclude that these three passages, unlike Vākyapadīya 1.182cd, refer to the same current of thought, probably Jainism.

It seems, then, at least possible to maintain that Vākyapadīya $1.182 \mathrm{~cd}$ refers to Buddhists who held that their sacred texts were composed in a language which, though appearing corrupt to orthodox Brahmins, represents in reality the origin of Sanskrit. Since we have no reason to believe that Bhartrhari was acquainted with the Pāli tradition and with its belief that this language was identical with Māgadhī, the original language, we are led to the conclusion that he may here refer to Buddhists who believed that some kind of Buddhist Hybrid

\footnotetext{
${ }^{400}$ Cf. Bronkhorst, 1988; and Houben, 1997; 1998; 1999.

${ }^{401}$ Mahābhāsyadīpikā, Āhnika I p. 16 1. 28-29: kecid evam manyante/ ya evaite prākṛtāh śabdāh ta evaite nityāh/ prakṛtau bhavāḥ prākrtāạ/

${ }^{402}$ Note however that elsewhere in the same commentary (p. 23 1.24) Bhartrhari ascribes a concept of eternality to the 'upholders of momentariness': ... kṣanikavādinām avicchedena pravrttir yā sā nityatā.
} 
Sanskrit was the original language, which formed the basis of other languages, including Sanskrit. ${ }^{403}$

The preceding considerations have made clear that the different religious currents of classical India which we have considered all shared the belief that their sacred texts were composed in the earliest language, the source of all other languages. In the case of Theravāda Buddhism and Jainism, this position was fairly straightforward. Their sacred languages, Māgadhī (i.e. Pāli) and Ardha-Māgadh̄̄ respectively, were the source of all other languages, including Sanskrit. The position of the vedic Brahmins was slightly more complicated, for the differences between Vedic and classical Sanskrit are considerable. But neither of these two was claimed to be the source of the other. Rather, Vedic and classical Sanskrit were maintained to constitute together one single language which, of course, was the language of the gods, the eternal language. It appears that at least some of those Buddhists who preserved sacred texts in Hybrid Sanskrit took essentially the same position as the Brahmins. They looked upon the language of their sacred texts as fundamentally identical with classical Sanskrit. They even used Vedic rules of Pānini to account for some of the special features of Hybrid Sanskrit. One line in Bhartrhari's Vākyapadīya, on the other hand, suggests that perhaps some of these Buddhists, too, entertained the claim that their sacred language was the source of Sanskrit.

\footnotetext{
${ }^{403}$ Hinüber (1988: 17-18; 1989) draws attention to the fact that some kinds of buddhist Sanskrit remain faithful to Middle-Indic, whereas others manifest the desire to adjust to correct Sanskrit. It is of course not impossible that these two tendencies were accompanied, or even inspired, by different views regarding the original language. See Hinüber's (1989: 349) remarks about Aśvaghoșa's ideas concerning the language of the Buddha.
} 


\section{III.5 Buddhism sanskritized, Buddhism brahmanized ${ }^{404}$}

The adoption of Sanskrit, we had occasion to observe, was no innocent matter. The present chapter will concentrate on the cultural "ballast" that inexorably accompanied this linguistic change for the Buddhists of the Indian subcontinent.

We have already seen, that the buddhist shift to Sanskrit went hand in hand with the relegation of matters political and societal to Brahmins. This did not imply that Buddhists henceforth approved of all that the brahmanical treatises on statecraft recommended. Some of the brahmanical recommendations clearly went beyond what the Buddhists found morally acceptable. These, however, were looked upon as excesses. Nor did it mean that the Buddhists were ready to accept the division of society recognized by Brahmins into four different caste-classes (varnas), to be looked upon as biologically distinct species. ${ }^{405}$ As a whole, a watered down version of the brahmanical vision of society and of kingship became the position which also the Buddhists accepted as normative. Where heretofore buddhist texts had depicted people, including Brahmins, as living in a non-brahmanical world, henceforth they depict them all, including Buddhists, as living in a brahmanical world. This can be illustrated by considering some buddhist narratives in Sanskrit.

Consider first Aśvaghoṣa's Buddhacarita, which may belong to the first generation of buddhist works directly composed in Sanskrit. It describes the life of the Buddha before his enlightenment. We came across this text before, where we had occasion to consider one of its passages that expressed itself in uncomplimentary terms about kingship. In spite of this, the initial chapters of the Buddhacarita describe in most laudatory terms the kingship of the Buddha's father, Suddhodana. Kingship and society are here presented as pervaded by brahmanical ideas and customs. Not only does his kingly father receive Brahmins to pronounce on the greatness of his new-born son; ${ }^{406}$ this episode has canonical

\footnotetext{
${ }^{404}$ Renou (1942: 191) ascribes the expression " "brâhmanisation' bouddhique” to Heinrich Lüders, without giving a detailed reference.

${ }^{405}$ Buddhist texts such as the Vajrasūci, the Särdūlakarnāvadāna $\left(33^{\text {rd }}\right.$ story of the Divyāvadāna) and the $77^{\text {th }}$ story of the Kalpanammanditika Drṣtāntapankkti protest against it; De Jong, 1988.

${ }^{406}$ Buddhac $1.31 \mathrm{f}$.
} 
precedents, as we know. Śuddhodana deviates from such precedents in having the birth ceremony (jātakarman) carried out, and in performing vedic murmurings (japa), oblations (homa) and auspicious rites (mangala) to celebrate the event, all this followed by a gift of a hundred thousand cows to Brahmins. ${ }^{407}$ Later on in the story he pours oblations into the fire and gives gold and cows to Brahmins, this time to ensure a long life for his son. ${ }^{408}$ He drinks soma as enjoined by the Vedas. ${ }^{409}$ He performs sacrifices, even though only such as are without violence. ${ }^{410} \mathrm{He}$ has a Purohita, ${ }^{411}$ described as being "in charge of the sacrifices" (havya...adhikrta). ${ }^{412}$ Brahmanical elements show up in other chapters as well, though less. When King Śrenya of Magadha gives friendly advice to the Bodhisattva,${ }^{413}$ he counsels him to pursue the (brahmanical) triple end of life (trivarga), i.e., pleasure (kāma), wealth (artha) and virtue (dharma). King Śrenya further points out that performing sacrifices is his kuladharma "family obligation". ${ }^{414}$ Māra, the Buddha's arch-enemy who tries to prevent him for attaining liberation, calls upon him to follow his svadharma. ${ }^{415}$ These and other examples show, not just that Aśvaghoṣa was familiar with Brahmanism (which has been known to scholars for a long time), but that he and his readers situated the Buddha in brahmanized surroundings.

Aśvaghoṣa's Saundarananda paints a similar picture of the Buddha's father. He here studies the highest Brahman, ${ }^{416}$ makes the Brahmins press soma ${ }^{417}$ which he drinks, ${ }^{418}$ he sacrifices with the help of Brahmins, ${ }^{419}$ and is said to be a follower of the Veda. ${ }^{420}$ The Saundarananda also emphasizes the martial side of

\footnotetext{
${ }^{407}$ Buddhac 1.82-83

${ }^{408}$ Buddhac 2.36.

${ }^{409}$ Buddhac 2.37.

${ }^{410}$ Buddhac 2.49.

${ }^{411}$ Buddhac 4.8; 8.82, 87; $9.1 \mathrm{f}$.

${ }^{412}$ Buddhac 10.1 .

${ }^{413}$ For a recent discussion of this term, see Wangchuk, 2007: $129 \mathrm{f}$.

${ }^{414}$ Buddhac 10.39 .

${ }^{415}$ Buddhac 13.9. "The Pali Canon does not use the term svadharma, or what would be its Pali equivalent" (Gombrich, 1996: 35).

${ }^{416}$ Saund 2.12.

${ }^{417}$ Saund 2.31.

${ }^{418}$ Saund 2.44.

${ }^{419}$ Saund 2.35-36.

${ }^{420}$ Saund 2.44.
} 
King Śuddhodana, a side which easily fits into a brahmanical world-view, less smoothly into a buddhist one. We read, for example, that the king "favoured those who submitted to him [and] waged war on the enemies of his race (kuladviș)". ${ }^{421}$ $\mathrm{He}$ "took away from his foes their mighty fame". ${ }^{422} \mathrm{He}$ "dispersed his foes with his courage"; 423 "by his holiness he put down the army of internal foes, and by his courage his external foes". ${ }^{424}$ "With the heat of his courage he reduced proud foes to ashes". ${ }^{425}$

We know that brahmanical culture did not constitute the background of the historical Buddha. Certain brahmanical notions appear in the canonical texts, mainly to be criticized. In Aśvaghoṣa's works the situation has completely changed. Here brahmanical notions and customs are the background of the Buddha. ${ }^{426}$ His own father is steeped in those notions and customs: he follows brahmanical ritual, performs brahmanical sacrifices and has a Purohita who is in charge of those sacrifices. Śuddhodana, moreover, is hardly a Dharma-king in the traditional buddhist sense, i.e. one who conquers the world without using violence. Ś Suddhodana is not averse to violence at all, and Aśvaghoṣa recounts with obvious delight how he destroys his enemies. This may be a more realistic depiction of a ruling monarch in ancient India, but that is not the point. Or perhaps one should say that Buddhism had yielded to the brahmanical vision of society and kingship because it was more realistic than anything Buddhism had to offer.

Aśvaghoṣa's detailed description of the Buddha's father as an ideal brahmanical king contrasts sharply with other contemporary biographies of the Buddha. The Mahāvastu, for all its length, has virtually nothing to say about Śuddhodana's accomplishments as a king. And the Lalitavistara presents him as

\footnotetext{
${ }^{421}$ Saund 2.10 .

${ }^{422}$ Saund 2.16.

${ }^{423}$ Saund 2.29.

${ }^{424}$ Saund 2.36 .

${ }^{425}$ Saund 2.39 .

${ }^{426}$ Olivelle (2008: xxxii) puts it as follows: "The Buddha's dharma, then, is not in opposition to the brahmanical tradition; it is not a 'heterodox' religion. Ashva-ghosha presents it as representing the highest aspirations of that tradition, as the fulfillment of its deepest yearnings, as its crowning achievement."
} 
an ideal buddhist king, without using any brahmanical terminology. ${ }^{427}$ Indeed, it would seem that Aśvaghoṣa himself invented the elaborate descriptions of the ideal kingship of the Buddha's father, perhaps even with the conscious purpose of glorifying brahmanical notions.

Not all Buddhists at that time shared this admiration for Brahmins. The attitude of the Mahāvastu appears to be quite different, for it does not even entrust to Brahmins the ability to interpret the marks on the body of the just-born Buddha-to-be, even though this is a traditional part of the story which already occurs in the ancient canon. The Mahāvastu replaces the traditional Brahmins with gods, and adds an uncomplimentary remark about the incompetence of Brahmins: ${ }^{428}$

When the child had entered the royal palace, the king bade his Purohita fetch at once the wise men who were skilled in the rules and significance of signs.

Learning this, the saintly devas, called Maheśvaras, (came on the scene), lest the unskilled crowd of the twice-born should seek to interpret the signs.

The twice-born are the Brahmins, and they are stated not to be good enough for the task at hand.

The contrast between the works of Aśvaghoṣa on the one hand and the Mahāvastu and the Lalitavistara on the other has to be seen in the light of the fact that Aśvaghoṣa's works were composed in Sanskrit, while the Mahāvastu and the Lalitavistara were not. The former of these two has been preserved in a Middle Indic language which is often referred to as Buddhist Hybrid Sanskrit, but which is a Middle Indic language none-the-less; ${ }^{429}$ the latter has been incompletely Sanskritized from Middle Indic. ${ }^{430}$

\footnotetext{
${ }^{427}$ Lal p. 26 f.; $\operatorname{Lal}(\mathrm{V})$ p. $17 \mathrm{f}$.

${ }^{428}$ Mvu II p. 27; similarly I p. 224. Tr. Jones, modified. Cp. Mvu I p. 150.

${ }^{429}$ Edgerton's (1953: I: 14) characterizes it as "a real language, not a modification or corruption of any other dialect on record, and as individual in its lexicon as it has been shown to be in its grammar."

${ }^{430}$ For thoughts about the reason why all forms of Middle Indic used by Buddhists underwent a process of Sanskritization (as distinct from a complete shift to Sanskrit), see Salomon, 2001: $248 \mathrm{f}$.
} 
The most important Theravāda, and therefore Pāli, source for the life of the Buddha is the Nidānakathā, which introduces the collection of Jātakas. ${ }^{431}$ Its middle portion, the Avidūrenidāna, covers by and large the same material as Aśvaghoșa's Buddhacarita; it is in its present form no doubt a few centuries younger. ${ }^{432}$ Like the Mahāvastu and the Lalitavistara, it has little to say about the kingly virtues of the Buddha's father. Since this text, at least in its present form, appears to have originated in Sri Lanka, and therefore outside of continental India, it can only play a marginal role in our reflections. ${ }^{433}$

Before we leave Aśvaghoṣa, we have to consider some observations by E. H. Johnston, the editor and translator of both his Buddhacarita and his Saundarananda. According to Johnston (1936: II: xviii),

[Aśvaghoṣa] had an acquaintance, so wide that no parallel can be found to it among other Buddhist writers, with all departments of brahmanical learning, including some knowledge of the Veda and ritual literature as well as mastery of all the sciences a kavi was expected to have studied. The deduction is inescapable that he was born a Brahman and given a Brahman's education, and as Chinese tradition is insistent to the same effect, we can for once accept its testimony without reserve as in accord with the evidence of the works.

It is perhaps not surprising that, during and soon after the shift from Middle Indic to Sanskrit, brahmanical converts to Buddhism like Aśvaghoṣa were almost bound to occupy prominent positions in literary production. Their mastery of Sanskrit was inevitably greater than that of regular Buddhists who had not grown up in a tradition steeped in that language. This relative prominence of Brahmin converts may have further contributed to the brahmanization of Buddhism, perhaps in a manner that was not or barely noticed by those involved. This process may also have worked the other way round, either by attracting Brahmins to Buddhism, or by inducing Brahmins who had converted to maintain their

\footnotetext{
${ }^{431}$ Hinüber, 1996: 55 f.; Reynolds, 1976: 50 f. The English translator calls the Nidānakathā "the Ceylon compiler's introduction" (Rhys Davids, 1878: vii).

${ }^{432}$ Hinüber, 1996: 152.

${ }^{433}$ Note in this connection the relative prominence of the kingly Purohita in the Jătakas; Fick, 1897: $107 \mathrm{f}$.
} 
brahmanical identity. We have seen that Brahmins continued to play a prominent role in the Buddhism of northern India.

Aśvaghoșa was not the only one to situate the Buddha in a brahmanical context. The second story from Kumāralāta's Kalpanāmanditikā Dṛ̣țāntapañkti, to be considered in chapter III.6, below, does the same. Here the Brahmin Kauśika becomes a buddhist convert as a result of reading a buddhist text on dependent origination. While subsequently discussing with his relative, he states that people believed in the Vaiśeșika philosophy, guided by ignorance, until the time when the Buddha appeared in the world. Vaiśeșika, according to Kauśika, is older than Buddhism. According to modern research, it is much younger. Indeed, we will see that it was created under the influence of scholastic developments within Buddhism. This same text, in story nr. 61, tells us that the Buddha, because he was born in a royal palace, mastered all branches of knowledge, which are then enumerated in a long list. This list contains, among many other things, knowledge of the Veda and of sacrifices, which are therefore once again presented as part of the background in which the Buddha-to-be grew up. ${ }^{434}$

Let us turn to the Jātakamālā of Āryaśūra, the earliest surviving collection of Jātakas composed in Sanskrit, dating probably from the fourth century CE. ${ }^{435}$ Jātakas, it may be recalled, are stories about the Bodhisattva in earlier lives.

The Jâtakamālā expresses itself more than once critically with regard to brahmanical ideas about statecraft. ${ }^{436}$ It calls them $n \bar{\imath} t i$, sometimes rājanīti. One passage speaks about "that vile thing called nīti" (nītinikrti). ${ }^{437}$ In another passage, the Bodhisattva who, as king of a group of monkeys, has saved all the members of his group at great risk to himself, admits that it is commonly thought that subjects are there for the king, not vice-versa. He then however comments: "That is indeed rājanīti; it seems to me difficult to follow. ${ }^{, 438}$ In another chapter the

\footnotetext{
${ }^{434}$ Huber, 1908: $311 \mathrm{f}$.

${ }^{435}$ Khoroche, 1989: xi f.

${ }^{436}$ Cp. Khoroche, 1989: 259, n. 6.2.

${ }^{437} \mathrm{Jm}(\mathrm{V})$ p. 45 1. 21; $\mathrm{Jm}(\mathrm{H})$ p. 63 1.15: dharmas tasya nayo na nītinikrtih.

${ }^{438} \mathrm{Jm}$ p. 179 1. 20-21; Jm(V) p. 186 1. 4: kāmam evam pravṛttā ... rājanītih/ duranuvartyā tu mām pratibhāti/
} 
Bodhisattva is told that untruth is prescribed in the Veda in order to attain certain goals, such as saving one's life, and that those who are skilled in the nitti of kings proclaim that the application of virtue that is in conflict with one's material interest and desires is bad behaviour and an infraction. ${ }^{439}$ The Bodhisattva disagrees, of course. Most elaborate perhaps is chapter 31, the Sutasoma Jätaka. Here the Bodhisattva, a prince who has initially been liberated by a man-eating monster, delivers himself again into the latter's power because he had given his word to come back. The monster observes: "You are not skilled in the ways of $n \bar{t} t i$, because you have again come to me even though I had liberated you so that you could rejoin your home ...." The Bodhisattva responds that, contrary to what the monster thinks, he is skilled in the ways of nit $i$, and that is why he does not wish to apply these ways. He then utters the following verse: "Those who are clever in the application of the ways of nit $i$ generally fall into misfortune after death. Having rejected the ways of nitti considering them deceitful, I have come back, respecting truth." 440

In spite of these critical remarks, the ideal king in the Jätakamāla behaves in accordance with brahmanical principles. This is clearest in stories where the Bodhisattva himself is depicted as king. In this elevated position he carries out deeds of great liberality and compassion, which move him forward on his path toward Buddhahood. We learn from these stories that a king, even an exceptionally good king, pursues the three brahmanical aims of life, the trivarga ${ }^{441}$ i.e., virtue (dharma), wealth (artha), and desire (kāma). He has extensive wealth and keeps a strong army. ${ }^{42}$ He applies justice (dandanitti), with the proviso that he does so in accordance with Dharma. ${ }^{443}$ In case of adversity, he takes

\footnotetext{
${ }^{439} \mathrm{Jm}$ p. 215 1. 11-14; Jm(V) p. 224 1. 20-22: apātakam hi svaprāṇaparirakṣānimittam gurujanārtham cānṛtamārgo vedavihita iti/ .../ arthakāmābhyām ca virodhidṛsțam dharmasaṃśrayam anayam iti svasanam iti ca rājñām pracakṣate nītikuśalāhl ${ }^{440} \mathrm{Jm}$ p. 2171.21 - p. 218 1. 5; Jm(V) p. 226 1. 13-25: mukto mayā nāma sametya geham, samantato rājyavibhūtiramyam/ yan matsamīpam punarāgatas tvaṃ, na nītimārge kuśalo 'si tasmāt// bodhisattva uvāca: naitad asti/ aham eva tu kuśalo nītimārge yad enam na pratipattum icchāmi/ .../ ye nītimārrgapratipattidhrtāh, prāyeṇa te pretya patanty apāyān/ apāsya jihmān iti nītimārgān, satyānurakșī punar āgato 'smil/

${ }^{441} \mathrm{Jm}(\mathrm{V})$ p. 7 1. 8; p. 71 1. $1=\operatorname{Jm}(\mathrm{H})$ p. 10 1. 8; p. 97 1. 5. Cp. Khoroche, 1989: 257 n. 2.2. ${ }^{442} \mathrm{Jm}(\mathrm{V})$ p. $121.21 ; \mathrm{Jm}(\mathrm{H})$ p. 18 1. 1: prabhütam me dhanam śakra śaktimac ca mahad balam.

${ }^{443} \mathrm{Jm}(\mathrm{V})$ p. 84 1. 11; $\mathrm{Jm}(\mathrm{H})$ p. 115 1. 11: dharmānugā tasya hi daṇdanītih.
} 
advice from the Brahmin elders headed by his Purohita. ${ }^{444}$ He has mastered the essence of the triple Veda and of brahmanical philosophy, ${ }^{445}$ and has competence in the Vedas along with its Angas and Upavedas. ${ }^{446}$ And the result of his perfect rule is that his subjects love their own Dharma (svadharma) ${ }^{447}$

Most of these features are brahmanical. The Purohita and the brahmanical elders who advise the king are, of course, Brahmins. The king's competence in vedic and associated brahmanical lore speaks for itself. The svadharma, which the inhabitants of the ideal kingdom love, is a brahmanical concept which we have encountered before. The same is true of the three ends of life (trivarga), which are basic to brahmanical texts such as Dharmaśāstra, Arthaśāstra and Kāmasūtra (to which they have given their names). ${ }^{448}$

The attribution of brahmanical characteristics to the society in which the Bodhisattva lived in earlier lives might be taken to mean that Āryaśūra, and other Buddhists with him, not only believed that Brahmanism is older than Buddhism, which is correct, but also that all of Indian society had been brahmanical at and before the time of the Buddha, which is incorrect. As a result, the Bodhisattva in his pre-final existences could not but have been born in a world governed by brahmanical principles. Historically, as we have seen, this is not correct even for northern India. But Āryaśūra and his contemporaries may well have thought so, and it is easy to guess why. The brahmanical order of society and its vision of political behaviour - or at any rate a slightly watered-down version of these two — had become the norm, and had been accepted as such even by Buddhists. This brahmanical order of society provided henceforth the very terminology with which to speak about the social and political world. Brahmanical ideology provided the norms as to how kings should behave, what was their task, what

\footnotetext{
${ }^{444} \mathrm{Jm}(\mathrm{V})$ p. 70 1. 20-21; Jm(H) p. 96 1. 23: purohitapramukhān brāhmanavṛddhān [u]pāyam papraccha.

${ }^{445} \mathrm{Jm}(\mathrm{V})$ p. 55 1. 4; $\mathrm{Jm}(\mathrm{H})$ p. 75 1. 4: trayyānvīkșikyor upalabdhārthatattva.

${ }^{446} \mathrm{Jm}$ p. 208 1. 1; Jm(V) p. 217 1. 7-8: sāngeșu sopavedeșu ca vedeșu vaicaksanyam.

${ }^{447} \mathrm{Jm}(\mathrm{V})$ p. 45 1. 25; p. $551.4=\mathrm{Jm}(\mathrm{H})$ p. 63 1. 20; p. 751.5.

${ }^{448}$ A more recent composition of Jātakas in Sanskrit, Haribhața's Jātakamālāa, shows brahmanical features, too. Its Candraprabha Jätaka, for example, tells the story of the Bodhisattva in his existence as King Candraprabha. Candraprabha is keen to give everything away, including his own head. Yet this same Candraprabha is said to be nìtibhujabalaparājitānyarājasāmanta, i.e. to have subdued other kings and vassals by means of statecraft (nīti) and the force of his arms. See Hahn, 2007: 68.
} 
preliminary knowledge they needed to possess, and to whom they had to turn for advice. Even an exceptionally virtuous king, even the Bodhisattva himself in an earlier life, would act accordingly.

We do not find this all-pervading brahmanical influence in the main surviving old collection of Jătakas, those in Pāli. The verses in this collection have canonical status, the prose portions do not. This does not necessarily imply that all the prose material is late. It is rather due to the fact that the prose, unlike the verses, remained for a long time in a fluid state and was newly formulated at each presentation. ${ }^{449}$ But neither in prose nor in verse do we find evidence of a dominant brahmanical ideology in the realm of kingship and society. Brahmins are omnipresent, to be sure, but their ideas about kingship and society are not presented as normative.

One example must suffice, and I propose the Gandatindu Jātaka (no. 520). ${ }^{450}$ This Jâtaka suits our purposes for various reasons: its theme is bad government, and it has numerous (canonical) verses. A recurring complaint about the king is expressed in a verse: "At night thieves devour us, by day taxcollectors. There are many evil people in the realm of a corrupt king. ${ }^{\star 451}$ This verse also states in a nutshell what a good king is supposed to do: make sure that his subjects are not devoured by thieves and tax-collectors. The Jātaka adds very little in terms of positive advice. No brahmanical notions are introduced, and it seems clear that this Jătaka, like the others, depicts a situation that is not coloured by brahmanical ideas about kingship and society. ${ }^{452}$ The general conclusion I propose is, once again, that Jātakas composed in Sanskrit situate their stories against a brahmanical background, while other Jātakas don't, or do so to a lesser extent.

Brahmanical influence is also clear in the following case, to which Ronald Davidson draws attention in his book Indian Esoteric Buddhism (2002). He says here (p. 79):

\footnotetext{
${ }^{449}$ Hinüber, 1998: $182 \mathrm{f}$.

${ }^{450}$ In this Jātaka the Bodhisattva is born as the divinity of a gandatindu-tree.

${ }^{451} \mathrm{Jā} \mathrm{V}$ p. 102 etc.

${ }^{452}$ Scharfe (2002: 142) explains "the dominance of vedic and technical studies" taught in Taxila according to the Jâtakas by means of the assumption "that in Buddhaghosa's time vedic and technical learning was too obvious to overlook".
} 
the brothers Mahāpanthaka and Cūlapanthaka - well-known arhats and standard personalities in the Avadāna literature - are considered illegitimate sons of a wayward daughter of a banking guildmaster (setthi) in the versions found in the Pali canon. Yet when their stories are rendered into Sanskrit ..., they become the sons of Brahmans.

In a case like this we must assume that newly brahmanized Buddhism found it difficult to think of illegitimate sons as beings persons worthy of the highest respect. Being the sons of Brahmins, on the other hand, is highly respectable.

Equally noteworthy is an observation by the Chinese pilgrim Xuanzang, who visited India in the seventh century. While describing the country called Śatadru, on the Sutlej river, he states that its inhabitants, devout Buddhists, observed the social distinction, i.e. the caste-class system. ${ }^{453}$ It is plausible to conclude from this that the brahmanical division of society had become accepted, for all practical purposes, even by Buddhists. ${ }^{454}$

Mātṛceța's Varnārhavarnastotra "Laudation for him whose praise is worthy of praise" is hardly the kind of text in which one expects brahmanical elements. But already while introducing its first chapter, Jens-Uwe Hartmann, its

${ }^{453}$ Watters, 1904-05: I: 299; Joshi, 1977: 21; Eltschinger, 2000: 157 n. 422.

${ }^{454}$ Sanderson (2009: 115 f.) refers to several inscriptions from eastern India that illustrate the same point: "[I]n the Neulpur grant of the Bhauma-Kara king Śubhākara I his grandfather Kșemankara is described both as a Buddhist and as having ensured that the members of the caste-classes and disciplines observed their prescribed roles; in his Terundiā copper-plate inscription Śubhākara II, the grandson of Śubhākara I, is given the epithet paramasaugatah yet is also commended for having 'propagated the system of uncommingled caste-classes and disciplines proper to the [perfect] Krta Age following the unexcelled [brahmanical] scriptures'; the Pāla Dharmapāla is described in a grant of his son Devapāla both as a paramasaugatah and as taking measures to ensure that castes that erred were made to adhere to their respective duties, thereby discharging his father's debt to his deceased ancestors; and Vigrahapāla III is described in his Āṃgāchi copperplate as the support of the four caste-classes. Moreover, most of the surviving inscriptions of the Pālas, Candras, and Bhauma-Karas record grants which they made in favour of Brahmins. The Rāmpāl copper-plate grant of the Candra Śrīcandra strikingly exhibits the extent to which this double allegiance was unproblematic for such buddhist donors. Following a practice widely attested in non-buddhist donative inscriptions the gift of land is said to have been made over to its Brahmin recipient after the pouring of water and the performance of a fire-sacrifice, in this case a kotihomah. This is simply adapted to the donor's faith by dedicating the offerings to the Buddha rather than to Siva or Viṣnu." 
editor and translator, draws attention to the brahmanical concepts used in its. ${ }^{455}$ More striking use of brahmanical elements occurs elsewhere in the work. Verse 2.20, for example, calls the Buddha a Brahmin who knows the Veda and the Vedāngas (vedavedāngavedine ... brāhmañāya). The second next verse calls him a snātaka, "a Brahmin who has performed his ceremony of ablution at the end of his vedic studies". Chapter 7 (Brahmānuvāda) goes further and "translates" a number of brahmanical concepts into buddhist ones. Most striking is the identification of the Buddha with the god Brahmā (7.13). ${ }^{456}$

Interestingly, among the buddhist works composed in Sanskrit there are some that deal with nīti. Nìti, and more in particular rājanīti, was reviled in the Jātakamālā, as we have seen. This was not surprising, because the kind of advice Brahmins gave to kings was unacceptable to Buddhists. It is therefore all the more noteworthy that at least one of the buddhist texts on nitti contains verses on polity and state-administration. This text, the Prajñāśataka (or Prajñāśatakanamma-prakaraṇa), is attributed to a Nāgārjuna, no doubt not the same as the one discussed earlier. It has only survived in Tibetan translation. It contains "praise of the brahmanical order including the practice of homa with mantras". It also "claims that it contains both direct and indirect merits as a source of dharma, artha, kāma and mokșa". ${ }^{457}$ In other words, this text, though buddhist, has absorbed the brahmanical vision of society, or at least some essential elements of it.

At this point it may be interesting to make a reference to a political debate that took place a few years ago in the United States. Opponents of President Bush claimed that his Conservative Party won the elections by "framing the debate". It succeeded in conducting discussions with Liberals in terms that were favourable to its own worldview. The philosopher George Lakoff analysed this practice in his booklet Don't Think of an Elephant (2004) and gave as example the

\footnotetext{
${ }^{455}$ Hartmann, 1987: 65. Hartmann draws attention to the terms śruti, prakșālana, punyatìrtha, pavitra and aghamarșana in particular.

${ }^{456}$ Cf. Ruegg, 2008: 24. Note further that the Kaliyugaparikathā ascribed to Mātrceta complains about the great sexual desire of Brahmins during the Kaliyuga; Dietz, 2000: 183.

${ }^{457}$ Pathak, 1997: 77; also 1974: $34 \mathrm{f}$.
} 
expression tax relief. "For there to be relief", he points out (p. 3), "there must be an affliction, an afflicted party, and a reliever who removes the affliction and is therefore a hero. And if people try to stop the hero, those people are villains for trying to prevent relief. When the word tax is added to relief, the result is a metaphor: Taxation is an affliction. And the person who takes it away is a hero, and anyone who tries to stop him is a bad guy. This is the frame." Lakoff points out that this expression came to be adopted by the news media, and concludes ( $\mathrm{p}$. 4): "And soon the Democrats are using tax relief — and shooting themselves in the foot."

It is not our concern to find out whether this analysis of the American situation was correct. It seems however appropriate to state that the discussion about society in ancient India was framed by the Brahmins. The Brahmins had a sophisticated terminology for the increasingly stratified structure of society, and those who disagreed with them had to use that same terminology, presumably because there was nothing else around. We noted earlier that the buddhist scriptures used one term, gahapati (Skt. grhapati), to refer to virtually every man but the king. It is not difficult to see that this left little opportunity for nuances. The only group on, or rather on the margins of, the Indian subcontinent that had an explicit notion about its social structure was that of the Greeks, who selfconsciously divided their society into two kinds of people: masters and slaves. ${ }^{458}$ We have seen that a relatively young passage in the buddhist canon, the Assalāyana Sutta, recognizes this fact and mentions the Greeks as the sole exception to the general brahmanical division of society. We have also seen that a passage in the (brahmanical) Mahābhārata disagrees, stating that the Greeks are Súdras. Obviously the pressure to talk about society in terms borrowed from Brahmanism was great. ${ }^{459}$ Opponents, even while arguing against the Brahmins'

\footnotetext{
${ }^{458}$ See Chakravarti, 2006: 71 (with references to Finley, "Between slavery and freedom", 1964): "It was only in classical Athens and Rome that the continuum was broken down and replaced by a grouping of statuses at two ends - the slave and the freeman. Slavery was no longer a single relative form among many in a gradual continuum but a polar condition of complete loss of freedom as opposed to a new concept of untrammelled liberty, and this new situation was a decisive contribution of the Graeco-Roman world." ${ }^{459}$ The brahmanical scheme and the reality of slaves stood in a somewhat uneasy relationship to each other; see Hinüber, 2008b.
} 
language, would in this way reinforce the frame. By framing the debate, the Brahmins had a clear advantage which contributed to their ultimate victory. ${ }^{460}$

Brahmanical influence on Buddhism is also visible in a peculiar terminological development within the latter. It concerns a specific sense attributed to the word yoga. The early Buddhists did not think of themselves as practitioners of Yoga. Indeed, their texts do not know the word in this "religious" sense. ${ }^{461}$ That changes subsequently. Not only do buddhist texts begin to betray awareness of people who practice Yoga ${ }^{462}$ they start referring to themselves as practitioners of Yoga ${ }^{463}$ Let me explain.

The Mahäbhärata and other brahmanical texts from roughly the same period distinguish between two methods to reach liberation, called Yoga and Sāmkhya ${ }^{464}$ It has been argued, convincingly I think, that the latter of these two, Sāmkhya, is in these texts the way to the spiritual goal through knowledge; the former, Yoga, the way through effort, exertion. ${ }^{465}$ A study of the passages that use the word yoga in this way supports the view that yoga is the term used in brahmanical circles to refer to ascetic practices that emphasize bodily control and

${ }^{460}$ Cp. Michaels, 1998: 188: "wer die Varna-Ordnung zur bestimmenden Hierarchie Indiens macht, argumentiert selbst brahmanisch-ideologisch."

${ }^{461}$ We should not forget that yoga is an extremely common term in Sanskrit, that can be used in many different meanings. Apte's dictionary (Apte p. 1316) gives it 42 distinct meanings, the vast majority of which has nothing to do with religious practice.

${ }^{462}$ Mvu I p. 120, which advises spiritual aspirants to avoid yogācāras, may fall in this category; cf. Silk, 2000: $284 \mathrm{f}$.

463 "Yoga in the Mülasarvāstivāda-vinaya would seem to have a very narrow and specific meaning. It does not refer to generalized meditation, but in fact to contemplation of the various - mostly unsavory - components of the human body that is 'full of various sorts of impurity' ('[...] shit, tears, sweat, snot', etc.), and is explicitly so defined at Posadhavastu ..., where its practice must be shielded from the public eye. Even the practices of dhyāna ('meditation' or 'contemplation') or cittaikägra ('mental focus') are in this Vinaya associated with cemeteries and corpses ..." (Schopen, 2006b: 240 n. 20) ${ }^{464}$ The claim is sometimes made (e.g. Wynne, 2007: 8) that the word yoga is first used in the sense of 'inner-concentration' in the Katha Upanișad (2.12), in the compound adhyātmayogädhigama. It is not however certain that the term is there used in this technical sense, because the ordinary sense effort may do: adhyātmayogādhigama might be translated "mastery of inner effort".

${ }^{465}$ Edgerton, 1924; 1965: 35 f. Johnston (1930: $856 \mathrm{n}$. 1) may be justified in stating: "I would argue ... against Edgerton's thesis ... that the term Sāmkhya has no definite philosophical significance in the Upanișads and the epics." This should not however be interpreted in the sense that a worked-out philosophical system named Sāmkhya was necessarily known to the authors of these texts. 
immobilization, practices that show remarkable similarities with those of early Jainism. ${ }^{466}$ The qualification "in brahmanical circles" is yet necessary, because the term is not used in this meaning in the jaina canon, nor indeed in most of later jaina literature. ${ }^{467}$

The buddhist canon does not use the term in this sense either, neither to refer to buddhist nor to non-buddhist practices. ${ }^{468}$ The way the word is used in the Mahābhārata would make it less suitable for use in connection with Buddhism, but here the epic has a surprise in store. The Śantiparvan of the Mahābhārata contains at least one undeniable reference to Buddhism, without mentioning its name, to be sure. ${ }^{469}$ The passage concerned speaks of a fourfold dhyannayoga. The four dhyānas (stages of meditation) meant are the four dhyānas of Buddhism, which can be concluded from various features mentioned. As in Buddhism, the goal to be reached is Nirvāna, also in this passage of the Mahābhārata. What is more, the first stage of meditation (the only one described) contains reflection (vicāra) and deliberation (vitarka), as well as joy (sukha), exactly as in Buddhism. ${ }^{470}$

What interests us in particular is that here buddhist practice is referred to by means of the word yoga, in the compound dhyanayoga. This may be the earliest surviving association of Yoga with Buddhism, but it was not to be the last one. The same compound is used by Aśvaghoșa in his Buddhacarita to describe the correct method found by the Bodhisattva to attain liberation. ${ }^{471}$ And in his Saundarananda the Buddha preaches to his brother Nanda, exhorting him to

\footnotetext{
${ }^{466}$ This was perhaps not the original way, and certainly not the only one, in which this word was used; see White, 2009.

${ }^{467}$ The book Jaina Yoga by R. Williams (1963) is therefore not about Yoga in this sense; as Williams points out (p. xi): "it is normal Śvetāmbara usage to equate the term yoga with the ratna-traya, that combination of right belief, right knowledge, and right conduct on which the practice of Jainism is based".

${ }^{468}$ One possible exception is Theraga atha 415 (Wynne, 2007: 27 f.). Here, as in the Katha Upanișad passage considered in an earlier note, the ordinary sense effort for yoga may yet suffice to reach an acceptable interpretation.

${ }^{469}$ Mhbh 12.188.1 ff. Zin \& Schlingloff (2007: $11 \mathrm{f}$.) draw attention to another passage in the Mahābhärata (3.2.60 ff.) that shows buddhist influence. It maintains that living beings are spun around in samsāra by ignorance (avidy $\bar{a})$, karman, and thirst (trṣnāa), all of them essential buddhist concepts. It further presents an eightfold path, like Buddhism, but reinterpreted in brahmanical fashion.

${ }^{470}$ Mhbh 12.188.1 f.; cf. Bronkhorst, 1993a: $68 \mathrm{f}$.

${ }^{471}$ Buddhac 12.105.
} 
practice Yoga. ${ }^{472}$ Here, then, a buddhist author uses the word yoga to refer to Buddhism's own religious practice.

There is in post-canonical days a pronounced tendency among Buddhists to refer to themselves, or at least some of themselves, as "practitioners of Yoga". ${ }^{473}$ The expressions used are yogācāra or quite simply yogin in Sanskrit, and yogâvacara in Pāli. Jonathan Silk (1997; 2000) has carried out a detailed investigation into the early use of these terms. About yogācāra he summarizes his findings by saying (1997: 233): “There is no evidence so far which could lead us to suggest sectarian limits on the use of the term, which can be quoted from literature of at least the Mahāsāmghika and Sarvāstivāda (and perhaps Sautrāntika) sects and schools. Likewise, the term is not restricted to one particular genre of literature, appearing in Vinaya, Abhidharma, and Mahāyāna sūtra and śāstra texts." The Pāli expression yogāvacara occurs most notably in the Milindapañha and a number of more recent texts.

The adoption by Buddhists of the term yoga to characterize their own practices, or some of them, cannot but be looked upon as a borrowing from Brahmanism. However, the adoption of this term both by Buddhists who had shifted to Sanskrit and by those who hadn't suggests that this particular element of brahmanical influence on Buddhism was not limited to those Buddhists who had also adopted a watered-down version of the brahmanical vision of society along with the Sanskrit language. Perhaps this is not surprising. The practice of Yoga is rather distant from visions of society and kingship. Buddhists could recognize that their practices had enough in common with certain forms of brahmanical asceticism to justify the use of the same word yoga. However this may be, the buddhist adoption of this term reminds us that even though the brahmanical influence on Buddhism was perhaps strongest among those Buddhists who had shifted to Sanskrit, it was not confined to them.

The general picture that emerges from the preceding reflections is that there was a general tendency, also among Buddhists, to conceive of Buddhism's past as

\footnotetext{
${ }^{472}$ E.g. Saund 5.32; 14.19-20, 34, 46; $15.68 ; 16.1$

${ }^{473}$ Cf. Schlingloff, 1964/2006: 29 f.
} 
having been dependent upon and in a way secondary to Brahmanism. In this understanding, which is really a misunderstanding, Buddhism arose out of Brahmanism in more than one way. Buddhism arose in a brahmanical society, but not only that. It derived its most original ideas and methods from Brahmanism, too. Buddhism, seen this way, is nothing but a form of Yoga, and Yoga is an aspect of Brahmanism that existed long before Buddhism.

Ideas like these are still wide-spread today. ${ }^{474}$ They may have accompanied Buddhism for a major part of its existence in India. Since many Buddhists were themselves ready to accept them, they may have acted like a Trojan horse, weakening this religion from within.

I do not wish to denigrate these ideas about the past. The history of ideas about the past, and how the present stands in relation to it, John Burrow (2007: xviii) reminds us, is also part of intellectual history. It deserves to be studied, even when we know that these ideas about the past do not always correspond to historical reality.

If the influence of Brahmanism on Buddhism may seem surprising, it will be useful to recall that Jainism appears to have been a lot less lucky than Buddhism in the treatment it received and in the influences it had to absorb. Giovanni Verardi (1996) describes the murderous persecutions which the Jainas suffered in

\footnotetext{
${ }^{474}$ This is no doubt in large part due to the buddhist literature in Sanskrit. This was the literature primarily studied and exploited by one of the pioneers of buddhist studies in Europe, Eugène Burnouf. Indeed, "[t]hough acknowledging the great value of the researches mades in the Buddhist literatures of Thibet, Mongolia, China, and Ceylon, Burnouf showed that Buddhism, being of Indian origin, ought to be studied first of all in the original Sanskrit documents preserved in Nepal" (Lopez, 2008: 161, citing Max Müller). Donald Lopez further states that Burnouf's Introduction à l'histoire du bouddhisme indien is arguably "the single most important work in the history of the academic study of Buddhism" (Lopez, 2008: 170). It laid the basis for buddhist studies in the West, and through it subsequent European scholars were breast-fed, so to say, on the "Sanskritic" vision of Buddhism's past. Burnouf based himself in this regard on the Divyāvadāna and other northern texts, including Aśvaghoșa's Buddhacarita (p. 168), and it is not surprising that he concluded that Buddhism arose in a completely brahmanized society. Burnouf's Introduction and the works he had primarily studied remained popular in the nineteenth century; the Buddhacarita appeared, for example, twice in the ten volumes devoted to Buddhism in the Sacred Books of the East (Lopez, 2008: 155). By the time earlier buddhist sources came to be studied in depth, this "Sanskritic" vision of Buddhism's past had become deeply anchored, far too deeply to be easily modified.
} 
South India, ${ }^{475}$ and enumerates the adjustments which they were induced to make.

I cite from his article the following passage, which is largely based on

Padmanabh Jaini's The Jaina Path of Purification (1979):

[I]n order to survive, [the Jainas] resorted to a sort of mimicry of the Brahman institutions and behaviours, that if, on one hand, assured them their survival, caused their weakening and the almost total loss of their identity. Jinasena, in the $8^{\text {th }}$ century ..., incorporated the sixteen samskāras of the Brahmans into the Jain system "almost in their entirety, becoming part of a larger list of fifty-three kriyas (actions) which marked all the important events of life" (Jaini 1979: 293). A "class of 'jaina brahmans' was introduced among the Digambaras, entrusted with the care of the temples and the performance of elaborate rituals" (ib.: 291), that could appear, in virtue of the consequent acceptance of the brahmanic bias against the śüdras (ib.: 294) and of the concept of "twice-born" (ib.: 28990) — in one word, of the caste system - as one of the different internal subdivisions of the brahmanic authority, and not as an élite which opposed it. The forced adjustment of Jainism to the Brahmanism of the bhakti should also be considered, that is, the acceptance of most brahmanic divinities and of amended versions of the Mahäbhärata and the Rāmāyana (the most important texts of the triumphant Vishnuite ideology; cf. ib.: 304-5 ...). Had Jain teachers ignored these texts — Jaini comments "they would have done so at the peril of their own society's disintegration" (Jaini 1979: 304). Only on these terms were the Jains allowed to survive as a community. From the brahmanic point of view, the Jina could be described (this is usual stuff) as the Universal Spirit who is Śiva, Dhātr, Sugata (i.e., the likewise neutralized Buddha), and Viṣnu ... ${ }^{476}$

The bad luck of the Jainas may be linked to the fact that they had lost almost all political support. The Buddhists were luckier, at least in certain part of India and for some time. They were therefore more successful in maintaining a separate

\footnotetext{
${ }^{475}$ See also Golzio, 1990; Stein, 1980: 80 f. For a convincing attempt to revise the traditional account of the Jainas in South India, see Davis, 1998. Examples of intolerance between Indian religions are enumerated in Jha, 2006: $27 \mathrm{ff}$.

${ }^{476}$ Verardi, 1996: 226. Dundas (2006: 393), referring to Bhagavatī Sütra 7.9, states: "Significantly, the Bhagavatī Sütra conveys no outright condemnation of the waging of war as such; rather it makes clear that going into battle when commanded by one's leader is obligatory, but also that going into battle with the wrong, impassioned attitude, specifically one not informed by Jain values, leads to an ignominious rebirth. In other words, there appears to occur here an example of an ambivalent view toward the institution of kingship and the imperial process, expressed through a reconfiguration of brahmin perceptions, which was to persist throughout Jain history ..." Note that on the literary level - according to Cort (1993: 202), with references to Jaini $(1977 ; 1980)$ Jainism vigorously opposed Hindu attempts at absorption, where Buddhism tended towards a syncretistic relationship with Hinduism.
} 
identity, ${ }^{477}$ even though they too absorbed a number of brahmanical elements.

Once they lost their political support, they disappeared altogether.

There is one important exception to this, and Verardi draws attention to it. It concerns Newar Buddhism in Nepal, which survives until today, but in a form which has been profoundly affected by Brahmanism. Indeed,

[o]ne of the most important features of Newar Buddhism is the performance, which is executed in different ways depending on the caste, of life-cycle rites parallel to the brahmanic ones ... Another feature is precisely the fact that Newar Buddhists are divided into castes according to hierarchies which reflect "Hindu" caste division. A third feature is that the priest caste, made up of vajrācāryas, corresponding in status and functions to the rājopādhyāya Brahmans ... is situated at the top of the system. In short, Newar Buddhism was forced to model itself entirely on the structures and values of brahmanical society and ideology. ${ }^{478}$

We may conclude that the brahmanical victory over Buddhism in the Indian subcontinent has been complete. Either Buddhism disappeared altogether or, as in the case of the Newar Buddhists, it survived in brahmanical shape. Buddhism had come to think of itself as a deviation from Brahmanism, and of Brahmanism as the default condition of Indian religion and society.

\footnotetext{
${ }^{477}$ This separate identity may in the long run have contributed to sealing Buddhism's fate in South Asia, and there may be some truth in the following observation by Annemarie Mertens (2005: 262): "Es ist m. E. nicht unwahrscheinlich, dass die von Anfang an mit grösserer Deutlichkeit demonstrierte Ablehnung des brahmanischen Werte- und Normensystems — mit der die Buddhisten sich nicht nur aus der Ständeorganisation, sondern auch aus anderen traditionellen gesellschaftlichen Institutionen 'exkommunizierten' — schliesslich zu ihrem Aussterben auf dem indischen Subkontinent beigetragen hat."

${ }^{478}$ Verardi, 1996: 241, with references to Gellner, 1992: 197 f., 43 f., 258 f. and passim. See also Vergati, 1994; Lewis, 1994.
} 


\section{III.6 Philosophical encounters}

One of the strongest cards in the hands of the Buddhists was their skill in philosophical debate. If our earlier reflections are correct, they had learned this from the Greeks. They had elaborated a coherent vision of the world, an ontology which claimed to contain an exhaustive enumeration of all there is and could explain much else. We may assume that the Buddhists were keen, in their confrontations with Brahmins, to discuss ontological and related matters so as to show their intellectual superiority. We may also assume that Brahmins who were obliged to enter into such debates felt the need to elaborate coherent philosophies of their own. ${ }^{479}$ This is indeed what happened. Two brahmanical ontological schemes gained the upper hand: Vaiśeșika and Sāṃkhya.

The second story in Kumāralāta's Kalpanāmaṇditika Drṣ̣ṭantapaìkti illustrates the Buddhists' self-assurance in doctrinal matters. It tells what happens to a Brahmin called Kauśika, expert in both Vaiśeșika and Sāṃkhya, who reads a manuscript to pass the time while waiting for a relative in the latter's village. It turns out that the relative had acquired the manuscript without knowing its contents in order to clean it and use it for writing another text. As it so happens, the manuscript contains a buddhist text on dependent origination (pratītyasamutpāda), a central buddhist doctrine which our Brahmin would not have become acquainted with in other circumstances. The result of this unplanned exposure is Kauśika's total conviction that only the teaching of the Buddha is true; all other doctrines are false. He is particularly impressed by the buddhist doctrine of causality, and explains its superiority to the Vaiśeșika and Sāmkhya views of causality to his relative after the latter's return home. In the end Kauśika decides to become a buddhist monk, without the intervention of a single Buddhist, whether monk or layman. The mere reading of a buddhist text has led him to this

\footnotetext{
${ }^{479}$ The character of brahmanical philosophy is largely determined by the fact that it is in origin a reaction to buddhist thought. This explains to at least some extent why brahmanical thinkers - unlike Chinese thinkers who were, like the Brahmins, closely involved with political counseling - concentrated on specific problems such as ontology, metaphysics, and philosophy of mind. This factor may count among the "reasons that might be conjectured for the particular views and modes of inquiry that came to be cultivated in the ways the did in India" (Lloyd, 2009: 20).
} 
point, as it convinces his relative and friends of superiority of the buddhist doctrine. $^{480}$

More will be said about the various brahmanical and buddhist ontological schemes below. Let us first consider an important general distinction that opposes buddhist and brahmanical philosophical thought during this period, whatever the details of their ontologies: buddhist philosophers were of the opinion that our common sense world is not ultimately real, brahmanical philosophers were convinced that it is. This opposition holds true for Buddhists and Brahmins during a number of centuries, roughly until the middle of the first millennium CE. Until that time, all buddhist philosophers denied the reality of the world of our every-day experience, and all brahmanical philosophers accepted it.

This striking distinction between buddhist and brahmanical philosophies raises an intriguing question. How is it to be explained? Let us not forget that nothing in the teaching of the Buddha as traditionally handed down suggests that ordinary reality does not exist. This idea was introduced later into the buddhist tradition and subsequently preserved for a number of centuries. Why? Was there perhaps a non-philosophical reason behind the brahmanical attachment to ordinary reality, and for the buddhist inclination to do away with it? Why were these Buddhists so determined to prove the illusory nature of ordinary experience?

The question is intriguing, and it would be overambitious to insist on an immediate and full answer. It is however tempting to consider the possibility that not only philosophical reasons are behind this great divide. Recall that in the confrontation between Buddhists and Brahmins at the royal court, the Brahmins (as a group, not necessarily the same individuals) were also the political advisors of the king, who helped him face the harsh realities of every-day life. It would hardly have been appropriate for them to deny these realities by denying the reality of the world of ordinary experience. The Buddhists, as we have seen, could not advise the king on such practical matters. Their aim was, and could not but be, to draw the king's attention to the higher realities of spiritual life, downgrading ordinary reality. Their subsidiary aim was to do so in a manner that

\footnotetext{
${ }^{480}$ Huber, 1908: 10 ff.
} 
would confound their brahmanical opponents by the inner coherence of their claims. The different roles that Brahmins and Buddhists played around the centres of political power may in this way have had repercussions on the kind of philosophies they developed. I present this as a hypothesis. Clinching evidence for or against it may be difficult to find, but it has the virtue of suggesting links between some of the metaphysical postulates of these early philosophies and their Sitz im Leben. ${ }^{481}$

Another fundamental difference between buddhist and brahmanical philosophy must be considered. Buddhist philosophy in its various manifestations is Buddhism, or at any rate it is Buddhism as learned debaters wished to depict it. Being convinced in a debate by a buddhist opponent might imply that one accepts his position and therefore becomes a Buddhist oneself. The same cannot be said of brahmanical philosophy in its various manifestations. No one could reasonably claim that Sāṃkhya and Vaiśeșika are Brahmanism, that they (or one of them) constitute what Brahmanism really is about. Brahmanism is primarily about society and about the role of Brahmins in it. One can adhere to it without feeling in any way bound by brahmanical philosophy. A Buddhist defeated in a debate with, say, a Sāmkhya, might become convinced of the truth of the Sāmkhya philosophy; he would not become a Brahmin for that matter, nor necessarily someone who accepted the brahmanical vision of society.

In view of this difference, there is a fundamental asymmetry between buddhist and brahmanical philosophy, an asymmetry that would make itself felt in debate situations: Brahmins might become Buddhists, but Buddhists could not become Brahmins unless they were already Brahmins. In other words, Buddhists might hope to strengthen their ranks by convincing Brahmins of the superiority of their thought, but Brahmins could not entertain such hopes.

This asymmetry was not just theoretical. We know of Brahmins who converted to Buddhism. Some few examples must suffice. Udbhațasiddhasvāmin,

\footnotetext{
${ }^{481}$ Since Buddhism had less practical advice to give than Brahmanism, it is possible or even likely that its religious message found favour, and tried to find favour, with women at the royal court, who were less directly involved in the daily affairs of state. Osto (2008: 120) states about the Gandavyūha: "The high status and important roles played by wealthy and royal female kalyannamitras provide additional evidence that the composers of the story had female royalty in mind."
} 
the author of two works called Viśeșastava and Sarvajñamaheśvarastotra, and his brother Śankarasvāmin, author of the Devatāvimarśastuti, both of uncertain date, appear to have been Brahmins who converted to Buddhism. ${ }^{482}$ Legend claims the same with regard to Aśvaghoṣa and Mātṛceța, and modern research supports this at least in the case of the former of these two. ${ }^{483}$ Bāna's Harsacarita, a classical Sanskrit literary work, tells of a thicket of trees in the Vindhya mountains inhabited by Divākaramitra, a Brahmin of the Maitrāyaṇī branch who has adopted the yellow robes of Buddhism; he is surrounded by students who are followers of all schools imaginable, from Jainas to Kṛṣna devotees, materialists, followers of Tantra and vedic ritualists, all of them engaged in scholarly and peaceful debate. ${ }^{484}$ I know no examples of Buddhists who had converted to Brahmanism.

This takes us to another question. Buddhists could not convert to Brahmanism in the ordinary sense: they could not become Brahmins unless they were already Brahmins. One is a Brahmin by birth, not through conversion. So what happened to Brahmins who converted to Buddhism? Could they remain Brahmins? Remember that Brahmanism primarily stands for a social order. Could a brahmanical convert to Buddhism keep his position in society as a Brahmin while at the same time accepting buddhist ideas and soteriological ideals?

Some indications suggest that this was indeed possible. Bāṇa's Harșacarita describes Divākaramitra, in spite of his conversion to Buddhism, as a brāhmaṇāyana "a Brahmin descended from learned and holy progenitors" (Apte). Other indications are not derived from fiction. The Kashmirian author Śankaranandana leaves no doubt about his buddhist convictions in his works, yet is consistently referred to as a Brahmin in the buddhist tradition. ${ }^{485}$ Many of the leading scholars at Nālandā, the great monastery/university of the eastern Ganges valley, came from Brahmin families. ${ }^{486}$ There are also several famous

\footnotetext{
${ }^{482}$ Schneider, 1993: 12; 1995; Hahn, 2000.

483 Johnston, 1936: II: xviii. Cf. Hartmann, 1987: 216.

${ }^{484}$ Bāna, Harsacarita, chapter 8; Scharfe, 2002: 163. Note that the Harsacarita does not use the word ásrama to refer to this place, whose description yet resembles the descriptions of āsramas in other texts, and compare this with Schopen's (2006a: 504) observation that âsrama "is a term that appears to be carefully avoided in [Buddhists'] descriptions or discussions of their monasteries."

${ }^{485}$ Eltschinger, 2009: 116-117 n. 11; forthcoming.

${ }^{486}$ Scharfe, 2002: 139 n. 45, with a reference to Misra, 1998: 282-302.
} 
brahmanical buddhist authors. Hartmut Scharfe (2002: 139) enumerates, beside Aśvaghoṣa, the philosophers Nāgārjuna and Vasubandhu, and the grammarian Candragomin. He further points out that Faxian, a Chinese buddhist pilgrim, saw in the monastery at Pātaliputra two famous professors of Mahāyāna, Rādhāsvāmin and Mañjuśrī, whom he calls Brahmins; this suggests that they were both Brahmins and Buddhists. Scharfe also refers to a story told by the Tibetan historian Tāranātha, which tells that the Brahmin Haribhadra was defeated in a debate by a Buddhist and, as a result, converted to Buddhism; however, he and his son, who worked as a buddhist missionary, continued to be called Brahmins. ${ }^{487}$ All these cases suggest that a social position as a Brahmin was considered compatible with an intellectual choice for Buddhism. ${ }^{488}$

This conclusion finds support in the fact that Jainism, too, came to have its Brahmins. Especially the Digambaras appear to have accepted this notion. Jinasena's Ādi Purāna, for example, states in so many words that Bharata, the son of the Jina called R̦̣abha, gave the title $d v i j a$, "twice-born", to a number of particularly virtuous devotees. He thus justifies and testifies to the existence of Brahmins among the Jainas. ${ }^{489}$ Prabhācandra's Nyāyakusumacandra, too, does so. ${ }^{490}$ It must further be noted that in modern India one can be Brahmin and Christian at the same time. ${ }^{491}$

\footnotetext{
${ }^{487}$ See further Angot, 2009: 26-27.

${ }^{488}$ See also Ruegg, 2008: 6 n. 3: "Abhinavagupta has alluded to a brāhmanaśramaṇanyāya in his Dhvanyālokalocana i.4 (KSS ed., p. 51); here the reference is to a temporal succession of two different states, the latter substituting for the former but the former designation of Brāhman still being applied to the ascetic (this has been rendered as "much as a śramana (buddhist monk) who was once a Brahmin is called a Brahmin śramana' in [Ingalls, Masson \& Patwardhan, 1990:] p. 81).”

${ }^{489}$ Jaini, 1979: $289 \mathrm{f}$.

${ }^{490}$ Dundas, 1991: $172 \mathrm{f}$.

${ }^{491}$ See, e.g., Das, 2005: 89: "In einem 1892 publizierten Buch, das Aufsätze der Jahre 1887-1889 vereint, berichtet Bhudev Mukhopadhyay über seine Begegnung mit einem tamilischen Christen, der stolz darauf war, ein Brahmane zu sein. Obwohl bereits sein Urgrossvater Christ gewesen sei, habe die Familie nie andere als Brahmanen geheiratet. Gegenwärtig sei er zu einem Tempelfest in Tanjore unterwegs, wo die Familie ab und zu die dort üblichen Verehrungsrituale der Gottheiten ( $p \bar{u} j \bar{a})$ ausführe, denn schliesslich habe man nur die Religion gewechselt, nicht aber die Kaste." Bayly, 1999: 18: "In south India it is common to encounter Christians who take pride in Brahman ancestry, and until recently many north Indian Muslims identified with the caste ideals of the lordly Rajput. Furthermore, as James Laidlaw has shown, most of the powerful north Indian traders who follow the austerely anti-brahmanical Jain faith are as insistent as their Hindu
} 
It may be difficult to prove beyond possible doubt that the contents of buddhist and brahmanical philosophies were in part determined by the different roles which Buddhists and Brahmins played at and around the royal court. It is easier to argue that the ideal philosophical debate took place at the royal court. Both inscriptional and textual evidence support this, even though a major part of this evidence comes from a relatively recent period. ${ }^{492}$ It seems likely that the more recent philosophical debates at the royal court were a continuation of a much older tradition, so that a brief presentation of some of this evidence will be useful. $^{493}$

Consider, to begin with, a long inscription at Sravana Belgola which commemorates the death of a jaina preceptor called Malliṣeṇa-Maladhārideva. Mallișeṇa-Maladhārideva died on Sunday, the 10th March 1129 CE, and the inscription was composed by one of his lay-disciples. It enumerates some forty earlier famous Digambaras, ${ }^{494}$ several of whom are reported to have engaged in public debates and to have defeated thinkers belonging to other schools of thought. Many if not most of these debates are said to have taken place at royal courts, often in the presence of the king. For example, the inscription attributes to Samantabhadra the following verses (vv. 7-8): "At first the drum was beaten by me within the city of Pātaliputra, afterwards in the country of Mālava, Sindhu, and Ṭhakka, at Kāñcipura [and] at Vaidiśa. I have [now] reached Karahātaka, which is full of soldiers, rich in learning, [and] crowded [with people]. Desirous of disputations, O king! I exhibit the sporting of a tiger. While Samantabhadra

neighbours on the importance of marrying within named Vaishya merchant jatis, while simultaneously claiming descent from converts of princely Rajput caste." Cf. Laidlaw, 1995: 111 ff. In 2004 the journalist Edward Luce and his wife "dropped in for tea at the home of a well-known Goan Catholic author. ... I naïvely asked her whether there was any Portuguese blood in the family. 'Oh no, that is out of the question', she said. 'Our family is Brahmin." (Luce, 2006: 311). Clémentin-Ojha, 2008: 244: "les distinctions sociales des chrétiens indiens d'aujourd'hui montrent que la conscience de caste n'est pas moins grande chez eux que chez les autres Indiens."

${ }^{492}$ Not all. Already the Mahäbhärata (14.87.1) speaks of debaters (hetuvādin) at the occasion of Yudhișthira's horse sacrifice who, eloquent and desirous to be victorious over each other, engage in many logical discussions (tasmin yajñe pravrtte tu vāgmino hetuvādinah/ hetuvādān bahūn prāhuh parasparajigīṣavah).

${ }^{493}$ See Bronkhorst, 2007a, for further details.

${ }^{494}$ E. Hultzsch in EpInd 3 (1894-95), 184 ff. 
stands disputing in thy court, O king! even the tongue of Dhūrjati (i.e., Śiva), who talks distinctly and skilfully, quickly wanders [back] into [its] hole. What hope [of success is there] for other [opponents]?"495

Even in debates that did not take place at the royal court, the presence of the king was much appreciated. This may be concluded from the following account occurring in The Life and Teaching of Nāropa. It describes what happened when Nāropa (1016-1100 CE) became head of a department at the university of Nālandā: ${ }^{496}$

According to the Indian custom when a new scholar was installed, it was the rule to hold a debate between the buddhist scholars and those of other philosophical systems. An announcement was made that a debate would be held in a fortnight, and all the scholars assembled in order to tear any professed doctrine to pieces. In the middle court of the university of Nalanda a throne was erected for the king, presiding over the conference. To his right and left the scholars, Buddhist and Hindu, were seated. First the Elder bsTan-pa 'dzin-pa (= Nāropa) debated with the Buddhists for half a month, but nobody could defeat him. Then the Hindus held forth for another fortnight, discussing grammar, epistemology, spiritual precepts, and logic. Contending with all sorts of spiritual powers and miraculous faculties, the Elder won a complete victory over his opponents. The king Phyogs-kyo go-cha (Digvarman) then addressed the assembly: 'I am the impartial patron of both parties. But in this contest to vindicate the truth nobody could defeat the Elder bsTan-pa 'dzin-pa and an unusual faith in the liberating power of the Victorious One (the Buddha) has been created everywhere'.

At that time the staff of Nalanda requested the Elder bsTanpa 'dzin-pa to become their abbot and they conferred upon him the name 'Jigs-med grags-pa (Abhayakīrti).

The venerable Abhayakīrti defeated all the non-buddhist scholars and he composed the following verses:

With the iron hook of grammar, the lore of knowledge, logic

And spiritual precepts

I, the Elder Abhayakīrti

Have scattered the opponents as a flock of sparrows.

\footnotetext{
${ }^{495}$ The tone of this inscription is very martial. It is in this connection useful to remember that "martial conquest is the central image and metaphor of Jainism, giving the religion its very name. So, to take three examples from the $[\bar{A} d i$ Purāna $]$ of a theme which recurs frequently in Jain literature: Jainism is described as a weapon of war (1.4), the various ascetic practices are compared to an army which conquers the enemy, karma (4.153 etc.), and the monk is instructed to abandon his body like that of an enemy on the battlefield (11.98)." (Dundas, 1991: 173 f.)

${ }^{496}$ Guenther, 1963: 20-22.
} 
With the axe of grammar, the lore of knowledge, logic

And spiritual precepts

I have felled the opponents' tree.

With the lamp of certainty in logic and precepts

I have burnt the darkness of my foes' ignorance.

With the sacred jewels of the three disciplines

Have I removed the dirt of impurity.

With instruction's battering ram

Have I conquered the vicious city of bewilderment.

At Nalanda in the presence of the king

Have I felled the ever trembling tree of the heretics.

With the razor of the Buddha's doctrine

I have shaved the hair of my opponent heretics,

And have raised the banner of the Buddha's doctrine.

At that time 100 learned Hindu teachers shaved their heads, were converted to Buddhism, and were followed three days later by another 600 . The inmates of Nalanda university hoisted the great banner, beat the big drum, blew the conch of the Dharma and were full of joy and happiness. The great king Digvarman showed his faith in and respect for the venerable Abhayakirti, bowed many times to him, and touched the latter's feet with his head saying, 'I am happy to be your patron'.

After the defeat of the heretical doctrines this great scholar spread the Buddha's message for eight years.

In view of all this it is not surprising that the so-called Hetuvidya portion of the Yogācārabhūmi, a buddhist text, mentions the rājakula "royal family, royal court, king" as the primary target of debates. ${ }^{497}$

What did debaters expect from such encounters at the royal court? The fact that the royal court is so often mentioned is a clear indication that the debaters hoped to impress not only their rivals but the king as well. Kings could provide them with protection and favours, such as honours and support in the form of gifts of money or land. The very best a debater could hope for was, inevitably, to convert the king to his cause. This did indeed sometimes happen. One verse (v. 52) of the Sravana Belgola inscription may have to be interpreted in this way: "Fortunate is that sage, on whom the Pāndya king, who had received a wealth of knowledge through his favour, conferred the title 'Lord' (svāmin), [and] whose

\footnotetext{
${ }^{497}$ Kang, 2003: 154 f. Kang argues for the interpretation "Zielgruppe" for Skt. adhikarana, the term used in the passage concerned.
} 
name Śabdacaturmukha was celebrated in the court of king Āhavamalla."498 Converting the king is also a theme that occurs in stories. The jaina scholar Hemacandra, for example, converted King Kumārapāla of Gujarat according to the Kumārapālapratibodha of Somaprabhasūri and the Prabandhacintāmaṇi of Merutunga. ${ }^{499}$ King Āma, son of Yaśovarman of Kanauj (eighth century CE) was converted by a jaina monk, according to Rājaśekhara's Prabandhakośa. ${ }^{500}$

Debaters, then, were interested in the king. Was the king interested in them? It is hard to find out. ${ }^{501}$ Debates are not often mentioned in inscriptions. Inscriptions regularly record donations, often of land. Occasionally the qualities of donees are mentioned as justification for a donation, but skill in debates does not figure among them, and references to specific debates are extremely rare. We learn from a stone inscription from Malhar, to be dated 1167-1168 CE, that a certain Brahmin called Gangādhara, described as 'king of the twice-born' and as someone who "in a crowd of hostile disputants resorted to [arguments] difficult to be met" (durggāśleṣakaro 'rivādinivahe), was in due time given a village by a king in another part of the country. ${ }^{502}$ Though no cause-effect relationship is specified, it is possible that Gangādhara had attained his reputation at least in part by means of his ability to stand up to the arguments of hostile disputants. It will be difficult to find further inscriptional evidence for kingly rewards for skilful

\footnotetext{
${ }^{498}$ Hultzsch (EpInd 3 (1894-95) 204 n. 3) interprets "who had received a wealth of knowledge through his favour" as "who was converted to the jaina religion". Cf. the stone inscription from Humcha, perhaps dating from around $1530 \mathrm{CE}$, described in Guérinot, 1908, no. 667, p. 238: "Éloge de Vidyānandasvāmin ou Vādi-Vidyānanda, chef des munis de Gerasoppe, et auteur du Buddheśa-bhavana-vyākhyāna (en canara). Il fréquenta la cour de plusieurs rois, entre autres celle du Cāngalva Nañjadeva, du Sāluva Kṛ̣nadeva, de Bhairava [...] Il soutint avec succès plusieurs controverses religieuses et fit, en particulier, abjurer la foi franque (Peringiya-mata = chrétienne?) à un vice-roi de Śrīrañganagara (Seringapatam). Aussi son éloquence est-elle comparée à celle d'Akalañka et de Bāna."

${ }^{499}$ Granoff, 1998: 10. Cp. Cort, 1998: 97. "Ācārya Hemacandra is reported by his jaina biographers to have converted the Śaivite King Kumārapāla (1143-72) by showing him a vision of Lord Śiva and obtaining from the latter a declaration that the religion of the Jina was superior to all” (Jaini, 1991: 190 [270] f.). See further Flügel, 2010: 12.

${ }^{500}$ Doniger O'Flaherty, 1983: 117.

${ }^{501}$ Ali (2004) does not mention debates in his study of courtly culture in early medieval India.

${ }^{502}$ Kielhorn in EpInd 1 (1892), 39-45.
} 
debaters. ${ }^{503}$

Other skills may have been much more interesting for worldly rulers. An inscription from Madhya Pradesh that may date from the very same year as the inscription from Sravana Belgola just considered has been summarized in the following manner: "In the presence of all astronomers at the court of Ratnadeva (II), Padmanābha asserted that there would be total lunar eclipse when three quarters of the night had passed and the moon was in the asterism Rohinī on Thursday, the full-moon tithi of Kārttika in the [Kalachuri] year 880 (8th November, 1128 A.D.). When the eclipse occurred at the predicted time, the king became pleased and donated the village of Chiñchātalā̄, situated in the maṇdala of Anarghavallī, to Padmanābha." ${ }^{504}$ An unexpected yet predicted eclipse, one might think, is more fun for a king than an unintelligible discussion about philosophical niceties. $^{505}$

Poetic competition as a means to gain rewards may be illustrated by an inscription from the eleventh century $\mathrm{CE}$ in which the gift of a village is recorded to a certain Nārāyaṇa who, "because by his clever verses he puts to shame wouldbe poets, is rightly called Kavībhavajrānkuśa, 'the adamantine elephant-goad of poets"". ${ }^{506}$ A treatise on poetry composed around $900 \mathrm{CE}$, the Kāvyamīmāms $\bar{a}$ of Rājaśekhara, presents the king as patron of poetry, who "is expected to organise a contest between poets. This contest is described as a public event, and is presided

\footnotetext{
${ }^{503}$ Typical may be a pillar inscription from around $900 \mathrm{CE}$ in Bengal, in which the Brahmin Guravamiśra, or Rāma Guravamiśra, sings his own praise in the following words: "In the assemblies of the learned he at once confounded the pride of self-conceit of opponents by his speeches to which the constant study of the Sāstras imparted deep meaning, just as, possessed of boundless wealth of valour, he did in battle the conceit of bravery of enemies" (F. Kielhorn in EpInd 2 (1894), pp. 160-167). The Brahmin apparently has to glorify himself, and no reward is mentioned. Guérinot (1908: 239) speaks of "Viśālakīrti, pontife du Balātkāra gaṇa, qui soutint avec succès une controverse à la cour de Virūpākșa [II?] de Vijayanagara (vers 1480 ap. J.-C.); son fils, Vidyānandamuni, qui fut honoré par le roi Sāluva Mallirāya". Was the son rewarded for the success in debate of the father?

${ }^{504}$ Sircar, 1983: 349; V. V. Mirashi in EpInd 22 (1933-34), p. 161, 162-63. Cp. Gupta, 1983: 25.

${ }^{505}$ Astrological activities did not only work in favour of Brahmins. Copper plates probably from the ninth century CE described by H. Lüders (EpInd 4 (1896-97), 332349) report that the jaina muni Arkakīrti was presented a village "for his having warded off the evil influence of Saturn from Vimalāditya, the governor of the Kunungil district" (p. 333).

${ }^{506}$ F. Kielhorn in EpInd 4 (1896-97), 300-309.
} 
over by the king. He acts as sponsor and as judge, dispensing presents and honours according to merit. In arriving at his judgements, the king may well have let himself be influenced by the opinions of the public., ${ }^{, 507}$

There can be no doubt that debaters could be confronted with what we might consider unfair competition. An inscription from the end of the twelfth century in a Śiva temple in Dharwar, not too far from Sravana Belgola, tells us that Jainas were confronted with a challenge against which their debating skills were of no avail. A devotee of Śiva called Rāma challenged them in the following manner: He would cut off his own head, offer it to Śiva, and get it back from him. They, from their side, had to commit themselves in writing to replacing their Jina image with an image of Śiva in case he succeeded. Unfortunately for the Jainas, Rāma succeeded completely. He cut off his own head, which was subsequently exhibited in public for seven days. At the end of this period he got it back without as much as a scar. The Jainas, the inscription tells us, were not keen to replace their Jina image. Rāma therefore took to action and destroyed their image. The Jainas went to King Bijjana and complained. Ràma then offered the king to repeat his feat, on condition this time that the Jainas committed themselves in writing to hand over all the Jina images from all of their eight hundred shrines. The Jainas would even be allowed this time to burn his separated head. King Bijjana would have loved to see this miracle, but the Jainas chickened out. King Bijjana, though a sympathiser of Jainism, thereupon laughed in their faces, dismissed them, and gave a village to the Śiva temple of Rāma. ${ }^{508}$

We may conclude from the above that the entertainment value of philosophical debates was limited for kings, who might prefer something more exciting. And yet debates might make a difference. The Buddhist Śīlabhadra, according to the Chinese pilgrim Xuanzang, once defeated a Brahmin in debate and received as reward from the local king the revenue of an entire city. And the Sāmkhya philosopher Vindhyavāsa, according to Paramārtha's The Life of Vasubandhu, defeated a buddhist priest, upon which he received a reward from the king of three lacs of gold (which he distributed among the people at large; see

\footnotetext{
${ }^{507}$ Tieken, 1992: 371.

${ }^{508}$ J. F. Fleet in EpInd 5 (1898-99), 237 ff.
} 
below) ${ }^{509}$ We may be entitled to some cautious scepticism with respect to such tales, but it seems nonetheless likely that some debaters sometimes profited materially from their skills. The following passage from Yijing's account of India confirms this: ${ }^{510}$
After [preliminary studies] one receives instructions from a tutor for two or three years, mostly at Nālandā Monastery in Central India, or in the country of Valabhī in Western India. [...] Those who are praised by wise authorities as excellent scholars become famous for their ability far and near. They may then believe that their sword of wisdom is sharp enough for them to go as competent persons to serve at the court of a king, making suggestions and displaying their knowledge, in hopes of being employed. When they take part in a debate, they always win the case and sit on double mats to show their unusual intelligence. When they carry on arguments to refute [heretics], they render their opponents tongue-tied in shame. Their fame resounds through the five mountains and their repute spreads within the four quarters. They receive feudal estates (grants of land, Takakusu) and are promoted to higher rank, with their names written in white high up on the gates of their houses.

Information about debates usually reaches us from the winning side, which is not surprising. ${ }^{511}$ Occasionally, however, we come across the avowal that the skill in debate of others has done harm to one's own party. An example is Kalhana's Räjatarangiṇ̄ 1.177-178, which reads: ${ }^{512}$ "At that period the Bauddhas, whom the wise Bodhisattva Nāgārjuna protected, obtained preponderance in the land. After defeating in disputation all learned opponents, these enemies of tradition brought to an end the [observation of the] rites prescribed in the Nìla[mata]purāna." The author of this passage is a Brahmin, who here admits the superior skills of the Buddhists in debating. Elsewhere in the same chapter he points out what Brahmins are good at (1.160-161): "Beyond conception is the power which austerities gain for those mighty Brahmins, who are capable of reversing the fortune of even such great [rulers]. One has seen the royal fortune when it had been lost through the power of [rival] heirs and others, restored again; but [when

\footnotetext{
${ }^{509}$ Bronkhorst, 2006: 16-17.

${ }^{510}$ Li Rongxi, 2000:149-150; cp. Takakusu, 1896: 177-178.

${ }^{511}$ Recent research by Madhav Deshpande suggests that both parties may have had a tendency to attribute victory to their protagonist; see note 526 below.

${ }^{512}$ Rājataranigin̄i 1.177-78; tr. Stein.
} 
once lost] in consequence of disrespect shown to Brahmins, it never returns." In other words, you Buddhists may be good at debating, but we Brahmins have something that is more important, viz., supernatural power. Reading between the lines, we may conclude that kings were, or should be, more interested in the powers of Brahmins than in the debating skills of Buddhists. ${ }^{513}$

If, then, debates between representatives of competing currents of thought were not primarily organized to amuse kings, how and why did they survive? How could disputatious philosophers induce kings and others to be present at their debates, and make them pronounce in favour of one or the other participant? The correct answer to these questions may well be the one suggested by Esther A. Solomon in her book Indian Dialectics (1976-78; chapter 3). Solomon sees a connection with legal courts: "the procedure of a legal dispute, its requirements, the requirements of a plaint or the answer to it, the legal terminology [...] as also its flaws find their parallel in the procedure of intellectual disputes or debates and matters connected with them, and the syllogistic statement of the arguments" (p. 93).

Solomon's suggestion finds support in a remark by an unspecified commentator on Paramārtha's The Life of Vasubandhu who explains that "it was customary for a king in India to keep a drum at the Royal Gate. When a man wants to appeal to the Court or to challenge a dispute, he has to beat it." (Takakusu, 1904: 283 n. 66). Note the mention of the drum, once again. The drum, it appears from this passage, was the instrument by which anyone who needed it could demand justice. This demand for justice also included that incorrect philosophical opinions be rejected by the court. This is clear from the

\footnotetext{
${ }^{513}$ Judging by Xuanzang's testimony, supernatural forces occasionally turn against Brahmins, too. This is clear from the explanation given locally of the "Pit of Descent" in western India. According to this legend a proud blasphemous Brahmin went down alive into hell at the spot where the Pit appeared: "This Brahmin had been vanquished in public discussion by the bhikshu Bhadraruchi, who was a consummate logician, and well versed in the non-buddhist saasstras. When the king condemned the defeated Brahmin to be exposed, as an impostor, to a cruel death the bhikshu interceded, and obtained a mitigation of the punishment. He then went to see the Brahmin to give him support and consolation in his shame and degradation, but the Brahmin gave vent to his passion, vilified the 'Great Vehicle' and abused former saints; while he was still speaking the earth parted, and he descended alive, leaving this trace (i.e. the Pit) of his descent." (Watters, 1904-05: II: 242).
} 
case described in The Life of Vasubandhu. Here the Sāmkhya teacher

Vindhyavāsa resolved to refute Buddhism. This he did in the following manner: ${ }^{514}$

[Vindhyavāsa] went to the country of Ayodhyā and beat the drum of dispute with his head and said: 'I will dispute (with any buddhist Śramana). If I am defeated my opponent shall cut my head off; but if, on the contrary, he is beaten, he shall give me his head.' The King, Vikramāditya [...], being informed of the matter summoned the heretic and asked him about it, whereupon the latter answered: 'Thou art, O King, the Lord of the Land, in whose mind there should be no partial love to either Śramanas or Brahmins. If there be any doctrines prevailing (in thy country) thou shouldst put them to the test (and see whether) they are right or wrong. Now I intend (to dispute) with a disciple of Śākya-muni [= the Buddha] to determine which party is the winner or the loser. Each should vow to stake his own head.' The King thereupon gave him permission and despatched men to ask all the buddhist teachers of the country in the following words: 'Is there anyone who is able to oppose this heretic? Whosoever thinks himself competent should dispute with him.'

At that time the great Teachers of the Law, Manoratha, Vasubandhu, and others were all absent travelling in other countries. [...]

There was at home only Buddhamitra the teacher of Vasubandhu. [...] This Teacher of the Law was formerly very learned, but he was now advanced in years and therefore weak in mind and feeble in his speech. He said: 'Now the great champions of the Law are all abroad. The heretic is strong and obstinate and must not be let alone any longer. I will now see to it myself.' He informed the King, who appointed a day on which he summoned a great assembly to the hall of discussion, where the heretic and the buddhist teacher were to meet and dispute.

The heretic said: 'Will you first set forth your opinion? Or will you refute the opinion first set forth by me?' The priest replied: 'I am like a great ocean which swallows up all that comes. You are like a lump of earth which will be submerged if it comes to the ocean. You may do as you like.' His opponent said: 'Then you had better set forth your own opinion (first). I will refute it.'

The buddhist teacher, thereupon, set forth his doctrine of impermanence and said: 'All composite things are in process of destruction every moment, why? because they disappear in the end.' $\mathrm{He}$ further supported this by various arguments. The heretic opponent could repeat all these arguments of the buddhist priest after once hearing them and began to criticise them one by one by processes of reasoning. On being requested to commit to memory and repeat these refutations the priest failed to do so. He could not even re-construct his own arguments, though requested to do so.

Thus the buddhist priest was completely defeated. The heretic said: 'You are a Brahmin by caste and I also am a Brahmin. We are not allowed

${ }^{514}$ Takakusu, 1904: $283 \mathrm{f}$. Cp. the discussion in Larson \& Bhattacharya, 1987: $131 \mathrm{f}$. 
to kill. I will beat you on the back instead, in order to show that I am the victor.' He did so. The king gave him three lacs of gold as a prize. On receiving the gold he distributed it among the people at large and returned to the Vindhya mountain where he entered a rocky cave.

Legal courts were a regular feature of Indian society, at least according to brahmanical literature. ${ }^{515}$ The Arthaśāstra emphasizes the need of unrestricted access to the king for all those who need it in a passage which we examined earlier (1.19.26-29). The interests of the Brahmins and their natural enemies, the heretics, have absolute priority in it.

It goes without saying that a hostile debate at the court would be a scary affair, and that all means would be used to win such a debate. ${ }^{516}$ The following paraphrase by Prets (2000: 369-71) of a passage from the Caraka-samhitā is illuminating: $:^{517}$

The Caraka-samhitā gives an elaborate description of what a debater must take into consideration before he agrees to enter a hostile debate. Remarkably interesting, this description is unique in the history of the Indian dialectical tradition, giving a lively picture of various types of debaters (vädin) and juries (parișad), which sounds like a guide to modern public political panel or TV discussions. Accordingly, the debater must examine his opponent, the opponent's personal and intellectual strengths or weaknesses which might be superior, equal or inferior to those of his own, and must also examine the jury's level of knowledge, which is described as either learned (jũanavat) or ignorant ( $m \bar{u} \underline{d} h a)$, and which may have a friendly (suhṛd), indifferent (udāsina) or hostile (pratinivișta) attitude towards the debater.

According to this passage, a debater should enter a debate only if the opponent is equal or inferior, and only in the presence of a friendly or,

\footnotetext{
${ }^{515}$ Debates could also take place at the court of muslim rulers. Guérinot (1908: 239) mentions "Simhakīrti, le logicien, qui défit les Bouddhistes à la cour du sultan Mahamuda de Dilli (peut-être Muhammad IV, 1434-1443 ap. J.-C.)". Amartya Sen is of the opinion that arguments remain dear to Indians even today; see his The Argumentative Indian (2005).

${ }^{516}$ Losing a debate at the royal court could presumably have dire consequences (death, slavery). But even elsewhere a lost confrontation can bring disaster, if we go by the testimony of the Mūlasarvāstivāda Vinaya: "when members of other religious groups (tīrthyas) are completely humiliated by the Buddhist Monk Sāriputra in a contest of 'magical' powers that humiliation is, at least in part, narratively signalled by the fact that, in order to remain in Śrāvastī, they are reduced to acting as day laborers on the monastery being built there, and must work under the eye of a latāvārikah purușo, a "man in charge of the whip' or 'work-boss"' (Schopen, 2006b: 228).

${ }^{517}$ Caraka-samhitā, Vimānasthāna 8.18-25; cp. Meulenbeld, 1999: 34 f.
} 
at the very least, an ignorant or indifferent jury. No discussions should be carried out in the presence of a hostile jury or with a superior opponent. After having considered the weak points of his enemy in the course of debate, he should overpower him quickly:

"Under these circumstances the following [procedures] are ways of quickly defeating inferior [opponents]: He should overpower an unlearned [opponent] by long citations of sütras; moreover, [he should overpower] an [opponent] who is weak in theoretical knowledge by [the use] of sentences containing troublesome words; an [opponent] who is unable to retain sentences, by a continuous series of sentences composed of long-strung sūtras; an [opponent] devoid of presence of mind, by the repetition of the same [words] with a difference of meaning; an [opponent] devoid of eloquence, by pointing to half-uttered sentences; an [opponent] devoid of selfconfidence, by embarrassing [him]; an [opponent] of irritable temper, by putting [him] to exertion; one who is frightened, by terrifying [him]; [and] an inattentive [opponent], by reprehending him. In these ways he should overpower an inferior opponent quickly."

Over and above that, he should take the jury into his confidence before entering such a debate, influencing it to name that with which he is familiar or that which could present great difficulties to the opponent as the subject of the debate and, at the beginning of the debate, he should pretend that the jury will set the subject and the rules of debate independently.

Others, and Brahmins in particular, might be tempted to use magical means as well. A passage in the Pāraskara Gṛhyasūtra (3.13) may give an impression of how such a Brahmin would go about. It concerns a court of justice in which one has to appear. The text suggests the following procedure: $:^{518}$

He approaches the court with (the words), "Court! ... Trouble art thou by name; vehemence art thou by name. Thus be adoration to thee!"

He then enters (the court) with (the words), "(May) the court and the assembly, the two unanimous daughters of Prajāpati (protect me). May one who does not know me, be below me. May (all) people be considerate in what they say."

When he has arrived at the assembly, he should murmur, "Superior (to my adversaries) I have come hither, brilliant, not to be contradicted. The lord of this assembly is a man insuperable in his power."

... if he should think, "This person will do evil to me", he addresses him with (the words), "I take away the speech in thy mouth, I take away (the

${ }^{518}$ Tr. Oldenberg, 1886: 362-63. 
speech) in thy heart. Wheresoever thy speech dwells, thence I take it away. What I say, is true, Fall down, inferior to me."

This passage does not only concern debates at the court of justice. Given that public debates took place at that court, we must assume that this procedure may have been used at such occasions, too.

A passage in Merutunga's Prabandhacintāmaṇi (written in 1304) deals more specifically with debate, and shows that also Jainas were willing to use magical means to prevail. Sanderson (2009: 244) presents it as follows: "Yaśobhadrasūri and other Mantra-adepts (māntrikāh) use the power that they have obtained by propitiating the goddess Kurukullā to unblock the throat of Devācārya when on the sixteenth day of a debate in the court of the Caulukya Siddharāja between him and the Digambara Kumudacandra the latter had used his supernatural power to silence him by causing him to choke". 519

Whether or not magical means were used in order to win debates, some brahmanical authors express in no uncertain terms their distrust of reasoning. The Laws of Manu are explicit in this regard: "If a twice-born disparages [scripture and tradition] by relying on the science of logic (hetuśāstra), he ought to be ostracized by good people as an infidel and a denigrator of the Veda." ${ }^{, 520}$ Those who occupy themselves with logic (hetu) are sophists (haituka) and should be avoided: "He must never honour the following even with a word of welcome: ascetics of heretical sects; individuals engaging in improper activities, observing the 'cat vow', or following the way of herons; hypocrites; and sophists." ${ }^{\text {"521 }}$ Logic should never contradict the Veda: "The man who scrutinizes the record of the seers and the teachings of the Law by means of logical reasoning not inconsistent

\footnotetext{
${ }^{519}$ Also the following description of Jagaccandra in Munisundarasūri's Gurvāvalī shows the use of unfair means to sharpen debating skills: "Having perceived through his own acuity a certain speech-enhancing magic device (yantra) in a temple of Sarasvatī, the goddess of wisdom, which was inaccessible to others, with its aid he quickly and successively conquered in full-scale competition in the learned assembly of the king of the city of Āghâta thirty-two fierce and mighty Digambara debaters who knew all branches of knowledge." (Dundas, 2007: 38)

${ }^{520}$ Manu 2.11: yo 'vamanyeta te tūbhe hetuśāstrāśrayād dvijah/ sa sādhubhir bahișkāryo nāstiko vedanindakah//. Tr. Olivelle.

${ }^{521}$ Manu 4.30: pāṣaṇ̣ino vikarmasthān baiḍālavratikāñ chaṭhān/ haitukān bakavṛttīmśs ca vāimātreṇāpi nārcayet//. Tr. Olivelle.
} 
with the vedic treatise - he alone knows the Law, and no one else." 522 But also Bhartrhari, though a philosopher himself, has no good word for unrestrained logic: "Logical reasoning, when not inconsistent with the vedic treatise, is the eye of those who cannot see." 523 And again: "Without tradition, the Law is not determined by reasoning. " 524 The same distrust for reasoning (yukti, hetuvāda) finds expression in the brahmanical apocalyptic accounts that depict Buddhism as a major threat, especially during the days following the decline of the Gupta empire in northern India. ${ }^{525}$

It would be incautious to think that Buddhists were more honest debaters than Brahmins; for them, too, much might depend on the successful outcome of such a confrontation. It seems yet fair to think that they felt, as a whole, less threatened by reasoning. It is possible that the Buddhists had introduced logical debate into India, and they may have gone on thinking that reasoning was ultimately on their side. The beginning of an early buddhist text on logic which has only survived in what is presumably a Chinese translation of a Sanskrit original whose author remains unknown — seems to confirm this. We read there (tr. Gillon, 2008: 22-23):

\section{Question:}

One should not engage in debate. Why? All those who engage in debate, by and large, promote hatred, arrogance and pride. Their thoughts are confused and their minds are rarely gentle or peaceful. They point out what is bad in others and proclaim what is good in themselves. ...

Answer:

This is not so. Now I have not undertaken this treatise for the sake of victory or to increase profit or fame. Rather, I wish to reveal all features (laksana), good and bad, [in debate]. Therefore I compose this treatise. If the world had no debate, the confused would be many. ... Furthermore, I wish to spread the true teaching of the Buddha all over the world. Just as, in order to cultivate the fruits of mango trees, one plants widely around them thickets of brambles so as to protect their fruits, now in writing [this] treatise I too act in the same way, for I wish to protect the true teaching of the Buddha (dharma) and I do not seek fame.

\footnotetext{
${ }^{522}$ Manu 12.106: ārșam dharmopadeśam ca vedaśāstrāvirodhinā/yas tarkenānusamdhatte sa dharmam veda netarah//. Tr. Olivelle.

${ }^{523}$ Vkp 1.151ab: vedaśāstrāvirodhī ca tarkaś cakṣur apaśyatām.

${ }^{524}$ Vkp 1.30ab: na cāgamād ṛte dharmas tarkena vyavatișthate.

${ }^{525}$ These accounts have been studied by Eltschinger (forthcoming a).
} 
It is possible that the pious feelings expressed by the author in this passage are no more than rhetoric, beautiful words to hide less elevated intentions. But even if it is mere rhetoric, it must be noted that this rhetoric is different from the one we came across in the brahmanical texts referred to above. At the brahmanical side we seem to find more distrust, even cynicism, with regard to logic, than at the buddhist side. A fuller investigation would be required to find out whether this observation has general validity. ${ }^{526}$

At this point it is necessary to briefly present some of the philosophical developments that took place during the first half of the first millennium CE. We have seen that the Buddhists from the northwest entered the scene with an well thought out ontology, capable of explaining the constitution of the world, and the role of language in it. One aspect of their ontology entailed that the objects of our ordinary experience are not real: we assume their existence on the basis of the words of language. Other aspects included the atomic nature of reality, both on a material and on a temporal level, and an exhaustive enumeration of all there is.

Of the two brahmanical ontologies mentioned above - Vaiśeșika and Sāmkhya - the first one is of particular interest in the present context, because it betrays in its most fundamental structure the influence of buddhist thought. ${ }^{527}$ This is not surprising if the historical picture here presented is correct. The newly developed buddhist ontology constituted a challenge to the Brahmins. Since initially they had nothing equivalent, the buddhist challenge set the tune. Brahmins called upon to respond had to think out a coherent ontology of their own which could face this challenge on all major points. They did so, and the result is known as Vaiśeșika. Vaiśeșika ontology disagrees in many respects with

\footnotetext{
${ }^{526}$ Madhav Deshpande has recently investigated ("Will the winner please stand up: conflicting narratives of a $17^{\text {th }}$ century philosophical debate from Karnataka", forthcoming) a relatively recent debate of which there are, exceptionally, surviving records belonging to both opposing parties. Interestingly, the question as to who won the debate is answered differently by these sources, each one attributing victory to its favorite candidate. Deshpande no doubt rightly concludes that the outcome of other debates, too, may often have been far less clear than we might think on the basis of the surviving sources. See Angot, 2009: 96 ff.

${ }^{527}$ Bronkhorst, 1992; 2006a.
} 
buddhist ontology, but is yet clearly structured around issues which the northwestern Buddhists had raised. Consider the following:

-The Buddhists claimed to have an exhaustive enumeration of all there is. Vaiśeșika created one, too.

-The Buddhists insisted on the atomistic nature of reality. Vaiśeșika did so, too. -The Buddhists maintained that composite objects do not exist. Vaiśeșika took the opposite position, claiming that composite objects are as real as their constituents. -The Buddhists held that ordinary reality (which is not "real") corresponds to the words of language. Vaiśeșika adopted the same claim with this difference that it maintained that all that exists corresponds to the words of language, and is real in the highest sense.

It will hardly be necessary to point out that Vaiśeșika ontology, in order to incorporate these positions, had to consider numerous detailed questions and issues, just as buddhist ontology had done earlier. The resulting doctrinal edifice is as impressive as the one erected by the Buddhists. One can easily imagine debates in which Buddhist and Brahmin protagonists would have ample opportunity to prove their philosophical sophistication and acuity, not to speak of their skills in debate. Note however that the Vaiśeșika belief in the reality of the objects of our ordinary experience is part of the fundamental axioms of this ontology, just as the buddhist disbelief in their reality is part of its ontology.

This is not the occasion for a discussion of Sāmkhya ontology. Let it be enough to point out that this ontology, too, never questions the reliability of our ordinary experience. As said earlier, the Brahmins were not ready to doubt the reality of the objects of normal experience. The Buddhists were, and the ontology they created in the northwest was but a first notification of more to come.

Once Brahmins had created ontologies on a par with the ontology designed by the Buddhists, the intellectual competition for precedence between the two groups arrived at a stalemate. The latter maintained that the world of our experience is real, the former that it isn't. Neither group could prove that they were right. All they could do was show that their respective positions in this matter fitted into sophisticated ontologies. But which of these two ontologies was correct? Or rather, independently of questions of ontology, is there a way to show 
that the world of our experience is or is not real? Both Buddhists and Brahmins needed a breakthrough that would show that their opponents were wrong. This breakthrough came from the side of the Buddhists, who succeeded in proving that the world of our experience cannot be real. It cannot be real, because the world of our experience is self-contradictory.

We do not know for sure who discovered the proof of the selfcontradictory nature of the world of our experience. The person who used it to launch an all-out attack against those who thought otherwise is Nāgārjuna. I will give an illustration of his way of arguing below. Here it must be emphasized that his opponents, including most notably his brahmanical opponents, took notice. Nāgārjuna's attacks forced them to rethink their positions, and to reformulate their philosophies in manners that made them immune to these attacks. This led to major changes in the philosophies concerned. Nāgārjuna's brahmanical opponents had to defend themselves, for they were committed to the view that the world of our experience is real.

One example must suffice to show how Nāgārjuna proved the unreality, or rather the impossibility, of the phenomenal world. In order to understand his argument, we must recall that both buddhist and brahmanical thinkers agreed that the objects of the phenomenal world correspond to the words of language. Nāgārjuna extended this idea slightly, so that it came to mean that the words of a sentence correspond to the things described by that sentence; this is what I call his correspondence principle. No one in Nāgārjuna's time and after it objected, which allows us to conclude that both Buddhists and Brahmins considered the idea in this expanded form unexceptionable. It covers statements such as "Mary reads a book". Everyone agrees that this statement describes a situation in which Mary, her book, and the act of reading have their place. But Nāgārjuna applies the same idea to statements such as "Mary makes a pot". The situation described by this statement does not contain a pot, and is therefore in conflict with the correspondence principle. Nāgārjuna does not conclude from this that there is something wrong with this principle. No, he concludes from it that it is impossible to make a pot. He expresses this, for example, in the following verse: 
"If any unproduced entity is found anywhere it could be produced. Since that entity does not exist, what is produced?" 528

I am not going to discuss Nāgārjuna's arguments in further detail. In the present context it is especially interesting to note that his brahmanical opponents had to invent a number of tricks to "save" phenomenal reality. According to them, Mary can make a pot. At the same time they did not see what was wrong with the correspondence principle. The various ways in which they struggled to accept both - phenomenal reality and the correspondence principle — have been studied elsewhere. ${ }^{529}$ The present publication cannot deal with them.

This brief sketch provides the necessary background for a discussion of an observation made by Vincent Eltschinger in a recent paper (forthcoming a). Eltschinger points out that there are nearly no textually or otherwise documentable hints at philosophical confrontation between Buddhists and Brahmins before the end of the $5^{\text {th }}$ century CE. What is more, "with few exceptions (Āryadeva's Catuḩśataka, the pseudo-Nāgārjuna's Vaidalyaprakarana, discussions scattered throughout Vasubandhu's Abhidharmakośa Bhāṣya), the Buddhists start systematically criticising brahmanical (and sporadically jaina) philosophies during the first half of the $6^{\text {th }}$ century, or slightly earlier in the case of Dignāga (Dignāga, Dharmapāla, Dharmakīrti, Bhāviveka, Guṇamati, Sagāthaka of the [Laìkāvatāra Sūtra], etc.). The same seems to hold true of the brahmanical philosophers' critique of buddhist doctrines (Nyāyavārttika, Vrttikāragrantha ${ }^{530}$ and especially [Ślokavārttika], Yuktidīpikā). Or, to put it otherwise, philosophical confrontation between Buddhists and non-Buddhists starts being reflected in extant philosophical literature from the beginning of the $6^{\text {th }}$ century onwards." Should we conclude from this that no debates between Buddhists and Brahmins took place before that date? Eltschinger does not make this claim, yet points out that there is no conclusive evidence to prove the opposite. What is more, he argues

\footnotetext{
${ }^{528}$ MMK 7.17.

${ }^{529}$ Bronkhorst, 1999.

${ }^{530}$ I have argued elsewhere that the opponent in the Vṛttikāragrantha is a Cārvāka rather than a Buddhist; Bronkhorst, 2007: 363 ff. (Appendix VIII).
} 
that the period which sees the beginning of philosophical confrontation between Buddhists and Brahmins reflected in extant literature, roughly the end of the Gupta empire, is also the period in which brahmanical apocalyptic eschatology begins to see in the Buddhists a major threat to the well-being of the world; this had not been the case so far.

Eltschinger's arguments leave little doubt that the opposition between Buddhists and Brahmins became much more intense from, say, the beginning of the $6^{\text {th }}$ century onward. However, our brief sketch of some crucial philosophical developments before this period, given above, shows that there had been interaction between buddhist and brahmanical philosophers from the very beginning. Somehow buddhist and brahmanical thinkers knew each other's ideas well enough to be profoundly influenced by them, and to take on shared problems more or less simultaneously. It can hardly be doubted that these earlier buddhist and brahmanical philosophers, too, were in competition with each other, even if this competition may not have reached the intensity and thirst for blood which it attained in the second half of the first millennium. There is therefore no need to abandon the hypothesis that buddhist and brahmanical thinkers confronted each other in debate, at least from time to time. If we combine this hypothesis with our earlier observation that systematic philosophy in India arose in surroundings where public debates may have been common - i.e., in the hellenized northwestern parts of the subcontinent - it seems safe to maintain that a certain amount of public debate did not only contribute to the beginnings of systematic philosophy in India, but continued to play a role and was responsible for its survival over the centuries as well.

Eltschinger is certainly correct in drawing attention to the important changes that took place in the middle of the first millennium. One further way apart from the intensified confrontation between Buddhists and Brahmins - in which it finds expression is the new form of brahmanical philosophy that joins the public debate roughly from that date onward. This is the Vedānta philosophy, thus called because it claims to be based on the texts called Upanișads, which constitute the end (anta) of the Veda. One of its branches, Advaita Vedānta, became in due course exceptionally popular. Advaita Vedānta is remarkable in 
that it abandons the most important single feature that united the different brahmanical ontologies until its time. Advaita Vedānta, unlike Vaiśeșika and Sāṃkya, accepts that the phenomenal world is an illusion. In other words, Advaita Vedānta claims for itself a position which had hitherto been the exclusive property of buddhist philosophy. ${ }^{531}$ The appearance of a totally different kind of brahmanical philosophy is interesting from a philosophical point of view. It is also interesting from a general cultural point of view. If our reflections so far are correct, the "realistic" bias of brahmanical philosophy had to be understood in the light of the practical role which Brahmins played at and around the royal court. The tendency of buddhist philosophers to deny the reality of the phenomenal world would then be linked to their incapacity to play a role, even an advisory role, in practical politics. The appearance and growing success of a brahmanical philosophy that yet claimed that the phenomenal world is an illusion suggests that some important changes took place in South Asia roughly from the middle of the first millennium onward. The collapse of the Gupta empire, emphasized by Eltschinger, is no doubt one of these changes. Other changes, too, took place, changes that affected both Buddhism and Brahmanism. We will discuss these in a later chapter.

\footnotetext{
${ }^{531}$ Bhavya or Bhā(va)viveka, a buddhist philosopher, is among the first to refer to this school. Interestingly, "[i]n Chapter iii of [his Madhyamakahrdayakārikās (III.389-90)] devoted to the quest for knowledge of reality (tattvajñana), this sixth-century Mādhyamika master has written that the supreme brahman not grasped even by the god Brahmā and other divinities is the supreme reality (satya) that the Buddha has proclaimed, and which great sages such as Ārya-Avalokiteśa and Ārya-Maitreya revere through the device of non-reverence." (Ruegg, 2008: 13; cp. Gokhale, 1962)
} 


\section{III.7 The relics of the Buddha}

\section{Relic worship}

We have so far concentrated on the confrontation between Buddhism and Brahmanism at and around the royal courts. This is where the confrontation took place in its most direct form. It would yet be one-sided to leave out of consideration the more subtle confrontation that took place in the world outside the royal courts. We know that Brahmanism owed its success to a double initiative. Brahmanism had not only done what it could to gain access to rulers, it had also spread its ideas to other layers of society, by other means. Among these other means we must count the diffusion of stories highlighting the power and excellence of Brahmins, and the purity that was (or was meant to be) exemplified in the lives of Brahmins. Brahmanical values found in this manner their way into the lives of people belonging to other layers of society. ${ }^{532}$

We know little about the way in which brahmanical ideas of purity spread. We do know that they were hard to reconcile with certain buddhist practices. The buddhist practice that most specifically disagreed with brahmanical ideas of purity is the worship of the bodily remains of the Buddha and other saints. This practice was not confined to Buddhism, and there are reasons to believe that it had been part of the culture of Greater Magadha. Buddhism and Jainism, and perhaps others, simply continued a tradition from their region of origin.

Let us first review some of the evidence suggesting that the worship of bodily relics was part of the culture of Greater Magadha. We find it in vedic literature. One passage of the Śatapatha Brāhmana (13.8.1.5) speaks about the "demonic people of the east" (āsuryah prācyāh [prajāh]). These demonic people from the east, we learn, were in the habit of constructing sepulchral mounds that were round. These round sepulchral mounds are contrasted with those in use among the followers of the Śatapatha Brāhmaṇa. The passage concerned reads, in

\footnotetext{
${ }^{532}$ The use of stories to inculcate moral and other principles is probably shared by all Indian religions and beyond; see, e.g., Flügel, 2010.
} 
Eggeling's translation: ${ }^{.33}$

Four-cornered (is the sepulchral mound). Now the gods and the Asuras, both of them sprung from Prajāpati, were contending in the (four) regions (quarters). The gods drove out the Asuras, their rivals and enemies, from the regions, and being regionless, they were overcome. Wherefore the people who are godly make their burial-places four-cornered, whilst those who are of the Asura nature, the Easterns and others, (make them) round, for they (the gods) drove them out from the regions.

Various scholars (e.g., Simpson, 1888: 61 f.; Shah, 1952: 278-80; Bareau, 1975: 163; Parpola, 1988: 254; Kottkamp, 1992: 9 f.; Witzel, 2003: 46) conclude from this passage that the Śatapatha Brāhmana here refers to people who did not adhere to vedic religion, and that their sepulchral mounds were the predecessors of the buddhist stūpas. Stūpa worship became particularly important in Buddhism, but Jainism, and perhaps also Ājīvikism, had their stūpas. Both literary references and archaeological evidence confirm this. A jaina stūpa has been identified in Mathurā (Smith, 1900). Paul Dundas (2002: 291 n. 4) recalls that stūpas were regularly built to honour eminent deceased jaina monks during the late medieval period. John Irwin (1979: 799) draws attention to a story in which the buddhist king Kaniṣka venerates by mistake a jaina stūpa. A passage in the early buddhist canon (Dīgha et Majjhima Nikāya) mentions a thūpa (Skt. stūpa) in connection with Niganṭha Nātaputta, the 'founder' (or better, most recent Jina) of Jainism. ${ }^{534}$ The buddhist texts also speak of the stūpa of Pūrana, one of the 'heretics' of Buddhism with links to Ājīvikism (Schopen, 1996: 571 sq.). It is plausible to conclude from all this that Buddhism and Jainism took over the habit of burying the remains of prominent persons in half-spherical mounds from the society out of which they arose.

\footnotetext{
${ }^{533}$ ŚPaBr 13.8.1.5: catuhsrakti/ devāśs cāsurāśs cobhaye prājāpatyā dikșv aspardhanta te devā asurānt sapatnān bhrātrvyān digbhyo 'nudanta te 'dikkāh parābhavaṃs tasmād yā daivyah prajāś catuhsraktīni tāh śmaśānāni kurvate 'tha yā āsuryah prācyās tvad ye tvat parimandalāni te 'nudanta hy enān digbhya[h]. Eggeling explains in a note that his proposed rendering "Easterns and others" is a (tentative?) translation of prācyāh tvad ye tvat.

${ }^{534}$ See further the Appendix to chapter III.7, below, and the Appendix to chapter III.3, above.
} 
A passage of the Mahābhārata which may be late and deals with the end of the Yuga shows that the worship of stūpa-like constructions was still associated with godlessness and social disorder at that date: ${ }^{.53}$ "This world will be totally upside down: people will abandon the gods and worship charnel houses (edūka), and the Śndras will refuse to serve the twice-born at the collapse of the Eon. In the hermitages of the great seers, in the settlements of the Brahmins, at the temples and sanctuaries (caitya) ${ }^{536}$ in the lairs of the Snakes, the earth will be marked by charnel houses, not adorned by the houses of the Gods, when the Eon expires, and that shall be the sign of the end of the Eon."

One of the major differences, then, between the culture of Greater Magadha and traditional vedic culture concerned the treatment allotted to the dead. The stūpa (whether buddhist, jaina, or other) continues a tradition that was known to, and criticized in, the Śatapatha Brāhmaṇa. We may assume that already before the rise of Buddhism these stūpas (by whatever name they were known) contained the mortal remains of dead people, and that these mortal remains were venerated. Brahmanism looked down upon anything that had to do with dead bodies. Dead bodies were here considered impure, and brahmanical ritual sought to get rid of dead bodies as soon and as efficiently as it could. The subsequent encounter between Brahmanism and the religions from the east (primarily Buddhism) would therefore be, at least in part, a clash between two altogether different ways of dealing with dead bodies. In this clash, notions of purity and impurity were to play an important role. With this in mind, I propose to consider some aspects of buddhist relic worship.

Gregory Schopen has studied in some of his publications passages from the Mūlasarvāstivāda Vinaya which show the concern of the authors of this text for ritual purity. ${ }^{537}$ In a recent article he draws attention to the consequences of the increasingly common practice of monks to live in permanent quarters

\footnotetext{
${ }^{535}$ Mhbh 3.188.64; tr. van Buitenen, modified. The term edūka (Buddhist Sanskrit eluka) refers no doubt to stūpas, but our passage does not tell us whether specifically buddhist, jaina or ājīvika stūpas are meant. Cf. Biardeau, 2002: II: 759-60. On the relative age of this passage, see González-Reimann, 2002: $95 \mathrm{ff}$.

${ }^{536}$ Biardeau (2002: I: 597) translates caitya "tumuli des ancêtres". This is a possible translation, especially in a buddhist context (cf. Strong, 2004: 19-20, with n. 50), but not the only possible one. Cf. Biardeau, 2002: II: 760.

${ }^{537}$ See, e.g., Schopen, 1992: 215 ff.; 1995: 474.
} 
(Schopen, 2006: 316):

Permanent quarters to remain so required upkeep and maintenance; such maintenance required donations beyond mere subsistence; such donations required the further maintenance of relationships with donors. But permanent quarters and the maintenance of relationships with the same donors over prolonged periods also exposed monastic doctrine and practice to prolonged and close observation by those donors, and necessarily required that monastic doctrine and practice conform to, or at least not collide with, lay values. Considerations of this sort alone, it seems, can account for one of the most striking characteristics of all buddhist Vinayas as we have them.

One of the results, Schopen points out a few pages later (p. 324), is that "one does not have to look very far in [the Mülasarvāstivāda] Vinaya [...] to find evidence for the fact that the buddhist monks who compiled it shared the broad brahmanical aversion and dread of any contact with a corpse". Indeed, "the redactors of the Mūlasarvāstivāda Vinaya framed a set of rules that could only have been designed to bring buddhist monastic practice in regard to handling a dead body into line with brahmanical notions of purity and pollution”. Schopen gives a number of examples of this, which cannot be repeated here. What concerns us at present is, how could Buddhists venerate the physical relics of the Buddha in surroundings that had such horror for anything to do with corpses?

Certain developments in Indian Buddhism - both in its religious practices and in its philosophical thought - become understandable against the background which I have just sketched. One of these concerns the role of stūpas in buddhist religious life. Stūpas often contain bodily relics of the Buddha. These relics are, for obvious reasons, objects of veneration. The stūpa, one might think, is nothing much beyond being the container of those relics.

In reality the situation is different. Already Alfred Foucher (1905: 52-62) - who, in his turn, could refer back to Burnouf and Wilhelm von Humboldt observed that the veneration of buddhist relics shifted in the course of time from relics to stūpa. The stūpa, as André Bareau points out (1962a: 269), now participates in the sacred character of the relics and of the person of the Buddha, which results in a kind of personification of the monument. Already before the 
beginning of the Common Era, the stūpa is more than a symbol for the Buddha, it is the Buddha himself.

The veneration of stūpas is not exclusively the concern of lay Buddhists. Monks and nuns participated in it from an early date onward. Monasteries were built next to stūpas (or stūpas next to monasteries?), ${ }^{538}$ which shows the interest that monks and nuns had for them. This interest may explain the need felt for a theoretical justification of this veneration of various objects related to but different from bodily relics.

The buddhist tradition provided useful elements to arrive at such a justification. The Buddha himself, according to that tradition, had several times emphasized the importance of his message rather than of his person. Not long before his death he had said that, after his disappearance, his teaching would be the master of his disciples. ${ }^{539}$ The teaching here referred to is called dharma in Sanskrit, dhamma in Pāli, and is to be distinguished from the rules of monastic discipline (vinaya). The Buddha even identifies with his teaching in remarks such as "He who sees the teaching sees me; he who sees me sees the teaching" (in Pâli: yo dhammam passati so mam passati, yo mam passati so dhammam passati). ${ }^{540} \mathrm{It}$ is hardly surprising that we find, already in the canonical texts in Pāli, the adjective dhammakāya (Sanskrit: dharmakāya), which means: "he whose body is the dharma", i.e., "he whose body is the teaching"; this adjective qualifies the Buddha. ${ }^{541}$ The idea one might derive from this expression is that the real, or the really important, body of the Buddha, is not his physical body or that what is left of it, viz., the relics. No, the real, or really important, body of the Buddha is his teaching. This idea could be used to criticize the cult of relics, or relativize its importance. There are indeed some passage which do so. This does not necessarily imply that the cult of the Buddha has to be abandoned, but rather that one must choose the specific objects of veneration with more care. Instead of venerating the physical remains of the Buddha, one should venerate his teaching.

\footnotetext{
${ }^{538}$ Certain Vinaya texts point out that the stūpa must be built before the monastery; Bareau, 1962a: 234.

${ }^{539}$ Bareau, 1971: 136 ff.

${ }^{540}$ SN III p. 120 (Vakkali Sutta).

${ }^{541}$ DN III p. 84; according to Meisig, 1988: $10 \mathrm{f}$., the Chinese parallels of this passage do not have this expression.
} 
This last injunction can, of course, be interpreted in numerous ways.

The teaching of the Buddha finds expression in the canonical texts which the buddhist community has preserved through the centuries, initially orally, afterwards also in written form. It is hard to venerate oral texts, but written texts can be made the objects of a cult. Several passages do indeed emphasize the superior character of these canonical texts in comparison with bodily relics, and specify that they are worthy of veneration. ${ }^{542}$ These passages do not tell us how the texts should be venerated. One could imagine written texts in the place of physical relics inside stūpas. Archaeological research confirms the existence of stūpas that contain canonical texts in the place of, or beside, relics. ${ }^{543}$ These manuscripts were sometimes called dharmaśarira "relics in the form of the teaching", which shows that they were looked upon as relics rather than as substitutes of relics. ${ }^{544}$

Manuscripts are not the only objects one can study as being the teaching of the Buddha. Other representations are possible, and have indeed been made the object of veneration. Some texts show that the stūpa itself was considered by at least some Buddhists a representation of the teaching of the Buddha. These Buddhists claim that each of the thirty-seven "dharmas helpful to enlightenment" (bodhipakșyāh / bodhipākșikāh dharmāh $){ }^{545}$ plus some other groups, corresponds to an identifiable part of the stūpa. ${ }^{546}$ The stūpa represents in this manner, through its various parts, the teaching of the Buddha.

The teaching of the Buddha is sometimes divided into 84'000 dharmaskandhas (see HBI p. $162 \mathrm{f}$.). This division is less current than the preceding one. However, 84'000 is also the number of relics collected, according to legend, by Emperor Aśoka, who then put them each in a separate stūpa. The idea underlying this legend appears to be that there is a homology, or even identity, between the body of the Buddha and the totality of his teaching. This

\footnotetext{
${ }^{542}$ See, e.g., Harrison, 1992: 47-48; Schopen, 1975.

${ }^{543}$ See, e.g., Salomon, 1999: 59 f.; Hinüber, 1983: 48; Kottkamp, 1992: 283 f.; Lévi, 1932a: $14 \mathrm{f}$.

${ }^{544}$ Foucher, 1905: 60.

${ }^{545}$ See on these Gethin, 1992.

${ }^{546}$ Roth, 1980. Cp. Bénisti, 1960: 89 f.
} 
idea finds expression in certain texts. ${ }^{547}$

Let us return to the expression dharmakāya. As we have seen, this expression occurs in the ancient canon as an adjective, meaning "he whose body is the teaching". The expression is subsequently also used as a noun, meaning "the body of the teaching" or "the body which is the teaching". In this way it could be used to refer to the teaching which is, as we have seen, the body of the Buddha. However, the expression also comes to be interpreted differently. ${ }^{548}$ One recurring idea in these interpretations is that the dharmakaya is more real than the physical body of the Buddha. A story told in the Karmavibhangopadeśa, for example, contrasts the destiny of two monks. One of them sees the physical body (rüpakāya) of the Buddha, the other one his dharmakāya. The Buddha comments by saying of the first monk: "He has seen this body which has come from my parents, he has not seen me." ${ }^{\$ 549}$

Certain buddhist doctors provide proof to show that the physical body of a Buddha cannot be his essential body. How else can it be explained that the Bodhisattva, as the biographies tell us, had to learn writing and numerous other things, in spite of the fact that he could recall earlier existences? How else is it possible that the Bodhisattva went in search of instruction with heretical masters, in spite of the fact that he had known buddhist doctrine for a long time? Why did the Bodhisattva dedicate himself to the bad practice of asceticism, even though he had known the right way all along? Asanga enumerates these and other paradoxes in his Mahāyānasangraha (4th cent. CE), and concludes from it that the physical body of the Buddha is not his essential body. ${ }^{550}$ Asanga does not speak of stūpas or of relics. His readers will nevertheless have understood that the veneration of the physical body of the Buddha, or of its remains, leads nowhere. Some other Mahāyāna texts, too, present arguments that seek to reduce the value of relics, or quite simply deny that they have any. ${ }^{551}$

\footnotetext{
${ }^{547}$ Strong, 2004: $36 \mathrm{f}$.

${ }^{548}$ See Bronkhorst, 2009: 153 ff.

${ }^{549}$ Lévi, 1932: 160, 174-75. Strong (2004: 141) relates another story of the same kind, found in the Mahāprajñāpāramitā Śāstra; see Lamotte, 1949-80: II: 634-36.

${ }^{550}$ Lamotte, 1938/1971: 331 f.; Griffiths et al., 1989: 252 f.

${ }^{551}$ See Schopen, 1987: 127; 1975: 180: "it is apparent from the texts cited above that the Mahāyāna of at least these documents is predominantly associated not with the stūpa cult,
} 
The stūpa as object of veneration has, from around the second century CE on, to face competition from the Buddha image. ${ }^{552}$ Even though a Buddha image may occasionally contain a relic, ${ }^{553}$ in the course of time images largely succeed in replacing stūpas and relics. There are indications that show that initially these images did not represent an abstract body of the Buddha, but quite simply his physical body. ${ }^{554}$ This would mean that Buddha images take the place so far occupied by his physical relics. Images make it in this way possible to venerate the memory of the last Buddha without being soiled by the cult of relics. Perhaps it is better to say that the image itself is the Buddha: archaeology confirms that the remains of an image after its "death" become themselves relics that are deposited in a stūpa. ${ }^{555}$

The preceding pages show that there was a tendency to reinterpret or modify the worship of bodily relics in such a manner that these relics play an ever reduced role. The worship of stuppas replaced the worship of the bones they were supposed to contain; the bones themselves were replaced by other objects, such as texts, that were considered to be the real body of the Buddha; etc. It appears that these shifts away from real bodily remains were a response to pressure from surroundings that had been influenced by brahmanical ideas about purity. But how can we be sure that brahmanical influence rather than other factors had this effect?

A survey of buddhist relic cults in regions that Buddhism did not share with Brahmanism will be revealing. Broadly speaking, Buddhism did not hide or replace its bodily relics in regions not affected by Brahmanism. Outside the Indian subcontinent and in regions of the subcontinent that Buddhism did not

but with the cult of the book. This association with the cult of the book, in turn, is invariably associated with an unambiguously negative attitude to the stūpa cult."; also Hirakawa, 1963: 88 n. 170 (for other Buddhists). Ulrich Pagel, in a paper read at the 13th Conference of the International Association of Buddhist Studies ("Stūpas and stūpa worship in Mahāyāna Buddhism"), points out that many Mahāyāna texts are not against the veneration of relics.

${ }^{552}$ See Schopen, 1988-89.

${ }^{553}$ Gombrich, 1966: 25; Strong, 2004: 20.

${ }^{554}$ Lancaster, 1974.

${ }^{555}$ Schopen, 1990: $276 \mathrm{f}$. 
share with Brahmanism, relics were not hidden or replaced. The tooth of the Buddha preserved in the Ceylonese town of Kandy, for example, is the object of a cult during which it is the central element of rites that represent the Buddha washed, dressed, and fed. ${ }^{556}$ The tooth leaves the palace in its reliquary at certain occasions. ${ }^{557}$ It is, or was, shown to its devotees at special occasions. ${ }^{558}$ If one lends credence to the testimony of an ancient Ceylonese text, the Mahāvamsa, this access to the relic continues an old tradition. This text reports that King Dutṭhagāman̄ī had put a relic of the Buddha in a ceremonial lance in order to be protected by it during his military campaigns. ${ }^{559}$ If one takes the text literally, it speaks of a proximity to the relics that is altogether different from what we know from mainland India. A modern researcher reports that he has indeed been shown relics in a Ceylonese village. ${ }^{560}$ It appears, furthermore, that the possession of relics is becoming wide-spread among the laity in Sri Lanka these days. ${ }^{561}$

In China, too, sources confirm that access to relics was not unusual. In Ch'ang-an, for example, once a year four teeth were shown to the public. The pilgrim Ennin reports that he has seen and even touched one of these in $841 .^{562}$ The public display of a bone of the Buddha, less frequently shown, was the occasion for ecstatic scenes. ${ }^{563}$ Ennin further reports to have seen, during his travels in China, the skull of a buddhist saint (Byakushi Buddha, Sanskrit pratyekabuddha), bones of the Buddha in a bottle of lapis-lazuli (p. 235), a tooth of a buddhist saint, bodily relics of the Buddha (p. 252-253), and to have worshipped bones of the Buddha that another monk had brought for this purpose (p. 288-289). The exhumation, public display and transport to the imperial palace

\footnotetext{
${ }^{556}$ Seneviratne, 1978: 41 sq. ; cp. ER 12, p. 280. Note that the relic itself is not touched (Seneviratne, 1978: 59). According to Trainor (1997: 96), the tooth in Kandy constitutes a special case, since most relics are in stūpas. For a deeper analysis of the treatment of relics in Sri Lanka, one should take into consideration that Sri Lanka has a caste system that is often considered a variant of the Indian caste system and in which degrees of purity and impurity play a role; see chapter II.2, above.

${ }^{557}$ Tambiah, 1984: 74; Seneviratne, 1963. This tooth has travelled a lot, also in historical times; see Strong, 2004: ch. 7.

${ }^{558}$ Hocart, 1931: 1.

${ }^{559}$ Greenwald, 1978; Trainor, 1997: 110 ff. Cp. Bretfeld, 2001: 109 ff., 126.

${ }^{560}$ Gombrich, 1971/1991: 126.

561 Trainor, 1997: 196.

${ }^{562}$ Reischauer, 1955: 301. Cp. Strong \& Strong, 1995.

${ }^{563}$ Ch'en, 1964: 279 ff.; 1973: 267 ff.; Dubs, 1946; cp. ER 12, p. 281.
} 
of a relic of the Buddha (a finger bone) were repeated on five occasions under the Tang from the seventh century on; public reactions were sometime passionate. ${ }^{564}$ In China, Tibet and Japan one finds, furthermore, mummies of monks that are objects of veneration. ${ }^{565}$ In Southeast Asia it is still possible to gain direct access to relics for contemplation. ${ }^{566}$

The testimony of Chinese buddhist pilgrims confirm that, where bodily relics are concerned, there is a contrast between parts of the Indian subcontinent that underwent brahmanical influence and those that did not. Faxian entered the subcontinent from the northwest around $400 \mathrm{CE}$ and passed some fifteen years travelling in India, followed by a visit to Sri Lanka. He describes the way in which bodily relics of the Buddha were handled in the extreme northwest (Nagarahāra, present Jalalabad, ${ }^{567}$ Afghanistan) and in Sri Lanka, but not in the central parts of the subcontinent. ${ }^{568}$ The other greater traveller of buddhist India, Xuanzang, mentions a number of relics of the Buddha, most of them hidden inside stūpas. However, most of the relics that he was able to see, or that, according to him, were regularly shown to the public, are in Baktra (Bactria), and in a monastery south-east of Bāmiyāna (Afghanistan). ${ }^{569}$ The absence of Brahmanism in Bactria at that time is well known. ${ }^{570}$ There are also reasons to think that Brahmanism was not, or hardly, present in neighbouring regions, notably Gandhāra. ${ }^{571}$ For the third century BCE Émile Benveniste (1958: 44)

\footnotetext{
${ }^{564}$ Chen, 2002: 43 ff., 98 ff.

${ }^{565}$ Demiéville, 1965; Sharf, 1992; Faure, 1991: 148 ff.

${ }^{566}$ Barthes, 1952; Strong, 2004a.

${ }^{567}$ Cunningham, 1871: 37 sq.

${ }^{568}$ Li, 2002: 171 sq.; 206 sq.; Legge, 1886: 36 sq.; 105 sq.; Demiéville, 1937: 204. Cp. Wang, 1984: 243.

${ }^{569} \mathrm{Li}, 1996: 33,38$ sq. Note that the inscription of Senavarma, which dates from the middle of the first century $\mathrm{CE}$ and belongs to the boundary region between Pakistan and Afghanistan, seems to say that this king had caused a relic of the Buddha to be distributed (Hinüber, 2003: 21: "Senavarma [...] hat [...] die (Reliquie?) weithin verteilen [...] lassen" (vivula vestario ... karita/ vipulā vaistārikā ... kāritā)). Behrendt (2004: 3031) draws attention to the existence of direct-access relic shrines and direct-access main stūpas in the region of Gandhāra.

${ }^{570}$ See, e.g., Staviskij, 1986: $195 \mathrm{ff}$.

${ }^{571}$ The Chronicle on the 'Western Regions' from the Chinese Hou Hanshu $\left(1^{\text {st }}\right.$ to $2^{\text {nd }}$ centuries CE) confirms the strong presence of Buddhism in Northwest India, describing it in the following terms (Hill, 2009: 31): "The kingdom of Tianzhu [Northwest India] is also called Juandu. It is several thousand $l i$ southeast of the Yuezhi [Kushans]. Their way of life is similar to that of the Yuezhi [Kushans], but the country is low, humid, and hot.
} 
comes to the conclusion, basing himself on his analysis of two Aramaic inscriptions, that Mazdeism prevailed in the region between Kandahar and Taxila. The weak presence, or absence, of vedic Brahmanism in these regions is further confirmed by brahmanical texts themselves. Several of these (Patañjali's Mahābhāṣya on P. 2.4.10, vol. I p. 475; on P. 6.3.109, vol. III p. 174, cp. Deshpande, 1993: 96 ff.; Baudhāyana Dharmasūtra 1.2.9-17; Vasiṣtha Dharmasūtra 1.8-16) describe the extent of the "land of the Āryas" (äryāvarta). For its western limit these texts use a somewhat obscure expression, often translated as the place "where the Sarasvatī disappears". ${ }^{572}$ This place is situated in the Thar desert that today separates the states of India and Pakistan. Patañjali adds an interesting remark. Composing his Mahābhāṣya in the middle of the second century BCE or soon after, he specifies, in the midst of a technical grammatical discussion, that the Śakas and the Yavanas live outside this territory ${ }^{573}$ Since the Yavanas of Patañjali are the Indo-Greeks, their mention confirms our suspicion that the western limit of Brahmanism at his time was perhaps situated somewhat near the present border between India and Pakistan, excluding Gandhāra and, of course, Bactria from the territory that Patañjali had in mind.

Recall further that the Assalāyana Sutta of the Majjhima Nikāya (MN II p. 149) states that there the four varnas do not exist among the Yonas and the Kāmbojas, and that an inscription of Aśoka claims that there are no Brahmins and

This kingdom is beside a great river [the Indus]. The people ride elephants into battle. They are weaker than the Yuezhi [Kushans]. They practice the Buddhist Way, not to kill, or wage war, which has become the custom."

${ }^{572}$ See chapter I.1, above. For a discussion of the obscure reading prāg ādarśāt, see Olivelle, 2000: 571, note 2.9. Manu's extension of brahmanical territory until the western sea does not necessarily include Gandhāra.

${ }^{573}$ La Vallée Poussin (1930: 202) "voit mal que les Śakas, en 170 ou en 150 avant notre ère, aient pris une importance assez grande pour que cet exemple soit possible, pour qu'ils soient dès lors intimement associés, dans l'estime des brāhmanes, aux Yavanas". Frauwallner (1960: 108-111 (300-303)) borrows La Vallée Poussin's argument and adds that Patañjali had no reason to mention, beside remote but Indian populations, also a nonIndian population, the Śakas. Whatever the value of this argument, it constitutes no reason to push Patañjali's date forward to a more recent time; cp. Cardona, 1976: $265 \mathrm{ff}$. Witzel (2003: 95), moreover, speaks of an invasion of the Śakas in the south of Afghanistan in 140 BCE. Frauwallner's point about the opposition between Indian and non-Indian populations seems to make little sense if one considers it from the point of view of an inhabitant of the "land of the Âryas". 
Śramanas among the Yonas. The Anuśăsanaparvan of the Mahābhārata and the Mānava Dharmaśāstra, moreover, state that no Brahmins are seen among the Śakas and the Kāmbojas. ${ }^{574}$

This conclusion finds support in other texts, too. Already the Śatapatha Brāhmana (9.3.1.24) speaks in very negative terms about the inhabitant of the region of the seven rivers that flow westward, i.e. the Punjab. ${ }^{575}$ The Baudhāyana Śrautasūtra enumerates the names of tribes that a good Brahmin should not visit, among them the Āratta and the Gāndhāra in the northwest. ${ }^{576}$ It is not clear where exactly the Ārața lived, ${ }^{577}$ the Gāndhāra, on the other hand, evidently lived in Gandhāra, a region that by this testimony was situated outside the realm where orthodox Brahmins lived at that time. ${ }^{578}$ It seems indeed that Brahmanism at the time of Patañjali and perhaps already before him spread mainly toward the east and south, starting from the "land of the Āryas". ${ }^{579}$ This impression is confirmed by recent research about vedic schools. ${ }^{500}$ These schools migrated toward the east

${ }^{574}$ See chapter II.1, above.
${ }^{575}$ Cp. Witzel, 1997: 302 .
${ }^{576}$ BaudhŚS 18.13; cp. Witzel, 1987: 202. The Kevaddha Sutta of the buddhist canon in Pali (DN I p. 213) speaks of a "science from Gandhāra" (gandhārì nāma vijjā; cp. the gāndhāri nāma vidyā of Abhidh-k-bh(P) p. 424 1. 18, under verse 7.47), which enables its possessors to multiply themselves, and other such things.

${ }^{577}$ Baudhāyana Śrautasūtra 18.44 suggests that Gandhāra and the land of the Ā/Aratta were separate from each other. Witzel (1989: 235) translates this passage: "Ayu went eastward. His (people) are the Kuru-Pañcāla and the Kāśi-Videha. This is the Âyava migration. (His other people) stayed at home in the West. His people are the Gāndhāri, Parśu and Arața. This is the Amāvasava (group).” Cardona \& Jain (2003: 33 sq.) propose a different translation: "Āyu went eastward. Of him there are these: the KuruPañcālas, the Kāśi-Videhas. This is the going forth of Āyu. Amāvasu (went) westward. Of him there are these: the Gāndhāris, the Sparśa, and the Arāṭtas. This is the (going forth) of Amāvasu."

${ }^{578}$ Brucker (1980: 147) states: "mit Gandhāra [begegnet uns] ein Land, das sicher schon sehr früh Kontakt mit den in Nordindien eindringenden Indern hatte. Um so erstaunlicher ist es, dass dieses Gebiet, das am Oberlauf von Sindhu und Vitasta zu lokalisieren ist, selbst in der Sūtrazeit noch nicht in die arische Siedlungsgemeinschaft inkorporiert war." The "noch nicht" of this passage suggests that Brucker believes that Gandhāra was subsequently incorporated in the area of Aryan colonization; he does not however provide any evidence to support this.

${ }^{579}$ Bodewitz (2002: 222) speaks of the "Veda Belt".

${ }^{580}$ See, e.g., Witzel, 1981 \& 1982; 1985; 1987. Witzel (1990: 31) sums up the results of his earlier studies concerning ancient vedic dialects: "These post-Rgvedic dialects can first be noticed in Kurukșetra and its surroundings and later on in all of Northern India, from the Beas in E. Panjab to the borders of Bengal." Cp. Witzel, 1985: 45: "Für eine Beurteilung der Verbreitung des Einflusses von vedischen Brahmanen im Mittelalter ist 
and the south, or even the north (Kashmir, ${ }^{581} \mathrm{Nepal}$ ), but it seems they never returned to the northwest. ${ }^{582}$ Several late-vedic texts know Gandhāra as a more or less remote region, and none of the vedic schools appear to be found there. ${ }^{583}$ The regions to the west of those inhabited by vedic Brahmins are home to the despised Bāhīkas, ${ }^{584}$ literally, outsiders. The term $b \bar{a} h \bar{k} k a$ is often confused with $b \bar{a} h l \bar{k} k a$ or bālhīka ${ }^{585}$ which designates the inhabitants of Bactria. The inhabitants of Gandhāra are depicted in the Mahäbhärata as being beyond the system of varnas, like fishermen. ${ }^{586}$ Kalhana's Räjatarangiṇ̄ (1.307) does states that there are Brahmins in Gandhāra, but looks down upon them for accepting agrahāras from a worthless king. ${ }^{587}$

Arrian's Indica clearly distinguishes between regions east of the Indus and those to the west of it. ${ }^{588}$ And about the history of art in Gandhāra, Mario Bussagli (1984/1996: 457) states the following: “Tout ceci nous parle d'une pensée religieuse en ébullition qui se développe en termes plus iraniens qu'indiens et qui [...] confère des notations, que je définirais comme irano-centrasiatiques, à la

zunächst von Bedeutung, dass sich hier eine ursprünglich auf das zentrale (und dann auch östliche und südwestliche) Nordindien begrenzte Tradition zu einem unbekannten Zeitpunkt (jedenfalls vor der Mitte des 1. Jtd.n.Chr.) nach Osten und vor allem über den Vindhya hinweg nach Südindien ausgebreitet hat." See further Witzel, 1989: 103 n. 12.

${ }^{581}$ See Witzel, 1994: esp. p. 259 ff., on the immigration of Brahmins into Kashmir, initially mainly from the centre of Manu's Āryadeśa.

${ }^{582}$ Witzel (1981: 116 n. 25) wonders, without proof, whether there have been "missionaries" who travelled toward the northwest to spread their ideas about ritual. The issue whether Brahmanism spread through missionaries who preached their views about ritual can be questioned.

${ }^{583}$ The Yajurveda-Vrksa mentions several schools that were supposedly situated yavanadeśe. Witzel (1982: 192), who provides this information, points out that the dates of composition of the different versions of this text remain unknown. He suggests that the text here speaks of the Greek Panjab, or of regions in Sind, later also in Panjab, that were occupied at an early date by the Moslems.

${ }^{584}$ Witzel, (1987: $202 \mathrm{n}$. 100) thinks that Bāhīka is a kind of nickname for peoples whose real names were Ārātta et Madra. See further Witzel, 1989: 128, with notes 66 and 67.

${ }^{585}$ MW p. 730 s.v. bāhīka.

${ }^{586}$ E.g., Mhbh 12.65 .13 ff.; 200.40-41.

${ }^{587}$ Chapter II.4, above. Evidence for a brahmanical presence in this later but still preMuslim period comes from statues and literary sources; Kuwayama, 1976; 1999; see further Meister, 2010.

${ }^{588}$ Wirth \& Hinüber, 1985: 614 ff.; Charvet, 2002: 31, 33. Cf. Thapliyal, 1979: 4: "during the greater part of the centuries immediately preceding the Christian era the Indus appears to be the substantial western boundary of India." 
religion intégrée par le langage gandharien, qu'elle soit bouddhique, sivaïte ou autre."

The virtual absence Brahmanism in the extreme northwest of the subcontinent, combined with a strong buddhist presence, goes a long way toward explaining the presence and accessibility of buddhist relics in those regions. Elsewhere in India this accessibility was reduced, and the worship of relics tended to make place for other forms of worship. Traces of relic cults yet remain in early sources (van Kooij, 1990). ${ }^{589}$ Xuanzang, in the seventh century CE, reports some cases in which relics of the Buddha were shown to the public in central parts of India. For example, a teeth of the Buddha was put on display in the capital of King Harṣavardhana, Kanyākubja. And in the Mahābodhi monastery, built by an ancient king of Sri Lanka and situated not far from the tree under which the Buddha had reached enlightenment, relics in the form of bones and flesh were shown. ${ }^{590}$ It is tempting to think that the involvement of the powerful king Harșavardhana in the first case, and the influence from Sri Lanka in the other, explain the open cult of relics in surroundings that appear to have frowned more and more on such practices.

It is important not to exaggerate the degree of public access to relics in buddhist countries other than India. John Strong (2004a) rightly emphasized that their access is less open than in western Christianity. This does not change the fact that there is a clear contrast between the regions that Buddhism had to share with Brahmanism and those, inside or outside the Indian subcontinent, where the influence of Brahmanism was weak or absent. In the former, much more than in the latter, buddhist relics tend to remain hidden or to be replaced by something else, whether it is a stūpa, an image, a text or an abstract notion such as the dharmakāya.

\footnotetext{
${ }^{589}$ According to Schopen (1985: 26 ff.), a passage of the Mülasarvāstivāda Vinaya preserves the memory of a time when relics were worshipped directly, without the intermediary of stūpas. Strong (2004: 36) defends a different interpretation of this passage: a stūpa is created at the end of the story.

${ }^{590} \mathrm{Li}, 1996$ : 150, 258.
} 
What happened to the body of the Buddha?

A chapter on the relics of the Buddha cannot be complete without some reflections on what really happened to the mortal remains of the historical Buddha. These can begin with a brief discussion of a topic in the history of buddhist studies in the West.

Hendrik Kern (1833-1917) was virtually the only Western scholar to maintain that the Buddha had no body and had never had one. The story of the Buddha's life, according to Kern, was a sun myth. I cite the words of J. W. de Jong who, in his A Brief History of Buddhist Studies in Europe and America (1997: 29), wrote the following:

In the first volume [of his history of Buddhism in India] Kern began by relating the life of the Buddha according to Pāli and Sanskrit sources ... After having retold the legend of the Buddha in great detail, Kern arrived at his interpretation. Like [the French scholar Émile] Senart, he considered the Buddha to be a solar god. However, Kern was much more astronomical in his exegesis than Senart. The twelve nidāna are the twelve months of the year. The six heretical teachers are the planets. The Buddha's first preaching takes place in midsummer, and this is why the Middle Way is its theme. Kern never hesitates in his identifications with stars, planets, and constellations.

Kern had been influenced by Senart. He also managed to convince Auguste Barth. But whereas Senart and Barth "did admit the possibility that reliable information had been handed down concerning the life of the Buddha", "Kern entirely dissolved the historical Buddha into the solar god" (de Jong, p. 30). ${ }^{591}$ In other words, Kern was alone in thinking that there was no such thing as a body of the Buddha.

\footnotetext{
${ }^{591}$ Hermann Jacobi, who translated Kern's Geschiedenis van het Buddhisme in Indië into German in the very same years in which the Dutch volumes came out, takes already in his "Vorwort des Uebersetzers" pain to distantiate himself from some of Kern's positions: "Von der Erlaubnis des Verfassers, zu ändern und zuzufügen, habe ich nur zuweilen in den Anmerkungen Gebrauch gemacht, um Einzelnes hinzuzufügen oder anders to deuten, wobei ich meine den ganzen mythologischen Erklärungsversuch betreffende abweichende Auffassung möglichst in den Hintergrund treten liess." (p. VIIVIII; my emphasis, JB)
} 
We see that Kern's ideas about the solar nature of the Buddha were already extreme in his own time. ${ }^{52}$ They have found no followers in more recent times. Unless I am seriously mistaken, the historical existence of the Buddha has not been called into question again since Kern. Different scholars hold different positions as to how much we know or can find out about the life of the historical Buddha. Some feel secure in reconstructing episodes from his life, where others are sceptical about the very possibility of doing so. But most would agree on the end of the Buddha's life. Here again, there may be differences about details; the main facts are generally accepted: The Buddha died in a small village, his dead body was incinerated, and the remains were put in a number of stūpas.

These events are crucial for the further development of Buddhism. It is probably no exaggeration to state that Buddhism in virtually all of its forms is, and presumably was, accompanied by relic worship. For many adherents relic worship was perhaps the only Buddhism they ever knew. Indeed, "[t]he cult of relics is central to all Buddhisms". ${ }^{593}$ Stūpas have followed Buddhism wherever it went, and many stūpas contain, at least ideally, relics of the Buddha's body. The distribution of these relics after the incineration of the Buddha's body is a vital part of Buddhism, much more vital for the religion than most things that presumably happened to the Buddha during his life. Many Buddhists may feel reassured that modern scholarship looks upon these specific events as fundamentally trustworthy historical facts, whatever the details.

Seen in this way, Kern's position has now been definitely abandoned. Contrary to what he thought, it is now generally believed that the Buddha did exist, that he had a body that was incinerated after his death, and that the remains of this physical body found their way into a number of stūpas.

It is not my intention to revive Kern's thesis. However, it may be that some of the certainties which buddhist practitioners and buddhist scholars appear to share are in need of reconsideration. A renewed consideration of the available evidence may throw some doubt on the veracity of this shared conviction.

\footnotetext{
${ }^{592}$ Kern, in his Manual of Indian Buddhism (p. 12), refers to "a few of the unbelievers" who "have gone to such length as to see in [the] history [of the Buddha] the remoulding of an ancient myth", and contrasts these with others who are "less radical".

${ }^{593}$ Skilling, 2005: 271.
} 
We have seen that the buddhist custom of relic and stūpa worship continues a tradition that is older than Buddhism and that the same tradition has survived in Jainism and perhaps $\bar{A}$ jīvikism. ${ }^{594}$ It is possible that essentially the same tradition is also preserved in a custom that is commonly thought of as Hindu. ${ }^{595}$ The corpses of certain renouncers are not incinerated, but buried. ${ }^{596}$ Sometimes their bodies are placed in a tomb; the name used in modern Indian languages for such tombs is samādhi, ${ }^{597}$ presumably because the renouncer concerned was believed to be enclosed in this tomb while in a state of yogic absorption called samāahi.$^{598}$ Local traditions sometimes maintain that the saint buried in this manner remains alive, immersed in yogic absorption. David White, a specialist of the Nath Yogis, tells me that these yogis are believed to be interred in these samādhis, packed in salt with head above ground and body below, rapt in eternal yogic trance and not really dead. Samädhis of this kind can become centres of pilgrimage, such as, for example, the samādhi of Jñānadeva in Alandi, near Pune in Maharashtra.

Véronique Bouillier, a specialist of Śaiva ascetic traditions, responded to my request for information about samāadhis in the following words (e-mail of $1.10 .2007):^{599}$

Ce sont ... effectivement des tombeaux dans lesquels l'ascète est enterré, immédiatement après sa mort, assis en position de méditation, padmasana. Il y a des règles quant à la profondeur de la fosse, sa disposition (face au nord) et ce qu'on y met: il fait verser une certaine quantité de sel (plutôt dans le cas des Dasnami Sannyasi) ou de sucre (dans le cas des Nath Yogis) dans la fosse avant de la combler. Une fois l'ascète enterré, un monument plus ou moins durable peut être érigé en fonction du statut ou du renom de l'ascète enterré.

Toutes les variations sont possibles: ainsi dans le cas de Sannyasi redevenus villageois que j'avais étudié au Népal, les morts étaient enterrés

\footnotetext{
${ }^{594}$ See further the Appendix to chapter III.7, below.

${ }^{595}$ For details, see Bronkhorst, 2005: $55 \mathrm{f}$.

${ }^{596}$ In Banaras, they can be weighted down and sunk in the river (Parry, 1994: 184).

597 "India is a country dotted with the samädhis ... of its great yogins" (White, 1996: 188).

${ }^{598}$ Zin (forthcoming) argues that such stūpa-like constructions, containing the mortal remains of respected teachers, were found from an early date onward in brahmanical āśramas.

${ }^{599}$ Cp. Bouillier, 1979: 139 f.; 175 f.; 1997: 153 f.; 2008: 43 f.
} 
au bord d'un fleuve, un entassement de pierres était disposé sur leur lieu de sépulture qui était emporté avec la crue du fleuve et nulle trace ne restait de leur tombe. Dans d'autres cas, il existe des sortes de cimetières. Le plus intéressant à mes yeux, c'est le lien entre samadhi et monastère. Beaucoup de math se sont constitués et se sont développés autour de la tombe où est enseveli leur fondateur. Cette tombe devient le point central du monastère et le point d'ancrage de la transmission de la lignée monastique. Autour de cette tombe initiale, peuvent être regroupées ensuite les tombes des successeurs. Il s'agit alors de véritables monuments, souvent de petits tumulus en forme de Shivalinga, dans le cas des monastères shivaites. Ces sépultures sont totalement intégrées à la fois aux lieux et à la vie rituelle des monastères qui les abritent.

Quant aux croyances qui accompagnent cet ensevelissement, il est vrai que l'on pense les ascètes plongés dans un état de profonde méditation et d'une certaine façon toujours présents, en samadhi, dans leur samadhi, en jouant sur les deux sens du mot. Si cette croyance est particulièrement importante pour les Nath Yogis qui ont fait de la recherche de l'immortalité le but de leur ascèse, elle n'est cependant répandue que pour les "grands ascètes". Ce sont eux que l'on tient pour particulièrement saints que l'on dit toujours et éternellement vivants, en "jivit samadhi". Cette expression est assez ambiguë; si elle désigne en principe ces ascètes qui ont atteint de leur vivant un état de Délivré, de nos jours elle s'applique plutôt aux ascètes qui ont, à la fin de leur vie, annoncé et programmé la date et l'heure de leur "mort", ou plutôt de l'arrêt de leur souffle. Ils sont alors enterrés à l'endroit même où ils sont expirés et leurs tombes sont vénérées et visitées par les dévots laïques.

Le culte qui se développe autour de ces tombes offre beaucoup de ressemblance avec celui qui entoure les tombes des saints musulmans, les grandes dargah.

Mais il reste toujours une grande incertitude de la part des gens ordinaires quant à la condition réelle de ces morts, et souvent une certaine crainte.

Parry (1994: 260) writes the following about Aghori ascetics:

Now my informants continually stress that as a result of his sadhana the truly accomplished Aghori does not die. He ... 'takes samadhi', and enters into a perpetual cataleptic condition of suspended animation or deep meditation. His body is arranged (if necessary by breaking the spine) in a meditational posture (known as padmasan), sitting cross-legged with his up-turned palms resting on his knees. He is then placed in a box which, in Banaras, is buried in the grounds of Kina Ram's ashram (and which is everywhere oriented towards the north). Unlike the householder, or ascetics of most other orders, his skull is not smashed to release the 'vital breath'. A small shrine containing the phallic emblem of Shiva is erected over the site of the grave, the emblem transmitting to the worshipper the power emanating from the ascetic's subterranean meditation. 
By entering samadhi (the term refers to his tomb as well as to his condition within it) which he is represented as doing by conscious desire at a time of his choosing, the ascetic unequivocally escapes the normal consequences of death: the severance of the connection between body and soul, the corruption of the body and the transmigration of the soul.

Provided that he has 'taken samadhi' while still alive (jivit-samadhi), rather than being 'given' it after death, his body is immune to putrescence and decay although it remains entombed for thousands of years.

It is true that samādhis of this kind do not appear in the archaeological records before the $12^{\text {th }}$ century $\mathrm{CE} .{ }^{600}$ It seems yet clear that they continue an earlier tradition, in which renouncers were not necessarily buried in tombs. Inhumation without stone or brick tombs has occurred from an early date on, and still seems to occur today. Abbé Dubois' Hindu Manners, Customs and Ceremonies, published in the first half of the $19^{\text {th }}$ century, but based without acknowledgement on a work by the French Jesuit Coeurdoux written in 1777, contains an elaborate account, presumably an eye-witness account of such a burial, which reads as follows: $:^{601}$

The ceremonies which accompany the funerals of sannyasis differ in many respects from those of ordinary Brahmins. Vanaprasthas, like ordinary Brahmins, are burned after death; but sannyasis are invariably buried, no matter what their rank or sect may be.

The son of a sannyasi (should the deceased have had one born to him before he embraced this state) must preside at the funeral. In default of a son, there is always some pious Brahmin who will take on himself the duty and bear the cost. There is often, indeed, much rivalry as to who shall have the honour of filling this office, as it is considered a most meritorious one. After the corpse has been washed in the usual manner, it is wrapped in two cloths dyed yellow with kavi. It is then rubbed all over with ashes, and a chaplet of large seeds called rudrakshas is fastened round the neck. While all this is going on the other Brahmins play on bronze castanets, which makes an ear-splitting noise.

Everything being in readiness for the obsequies, the body is placed, with its legs crossed, in a large bamboo basket, which is hung from a strong bamboo pole by ropes of straw. This basket is borne by four

\footnotetext{
${ }^{600}$ Bakker (2007: 35) thinks that the appearance of samädhis in the post 1200 CE period may be partly due to Islamic influence: "How to explain that we have no archaeological evidence of this sort of ancient monuments of yogins, whereas we have innumerable ones of buddhist saints?" See however below. There is some confusion inside the Nāth Yogī tradition about the Muslim appearance of some recent samādhis (Bouillier, 2004: 189). ${ }^{601}$ Dubois, 1906: 538 f.; for Coeurdoux’ original French, see Murr, 1987: I: $131 \mathrm{f}$.
} 
Brahmins. The grave must be dug near a river or a tank, and must be about six feet deep and circular in form. When they reach the spot the Brahmins deposit at the bottom of the grave a thick layer of salt, on which they place the deceased, with the legs still crossed. They then fill the hole with salt till it reaches the sannyasi's neck, pressing it well down so that the head may remain immovable. On the head, thus left exposed they break innumerable cocoanuts until the skull is completely fractured. They then, for the third time, throw in salt in sufficient quantities to entirely cover the remains of the head. Over the grave they erect a kind of platform, or mound, three feet in height, on the top of which they place a lingam of earth about two feet high. This obscene object is immediately consecrated by the Brahmins, who offer to it a sacrifice of lighted lamps, flowers, and incense, and for neiveddya, bananas and paramannam, a dish to which the Brahmins are particularly partial, and which is composed of rice, cocoanut, and sugar. While these offerings are being made, hymns are sung in honour of Vishnu, all present screaming at the top of their voices.

This discordant music over, the presiding Brahmin walks round the lingam three times, makes a profound obeisance to it, expresses the hope that by virtue of the sacrifice offered to the image the deceased may be fully satisfied, that Siva may look favourably on him, that Brahma may receive him into his abode, and that thus he may escape another reincarnation in this world. He then pours a little rice and a few drops of water on the ground, picks up all the fragments of the cocoanut shells that have been broken on the head of the deceased, and distributes them to those present, who scramble for the pieces, so eager are they to possess these relics, which are supposed to bring good luck. The paramannam is then divided among those who have no children, for when acquired under these circumstances it possesses the power of making barren women fruitful. The ceremonies of the day end with ablutions: not that the mourners need to purify themselves from any defilement, because none is contracted in attending the funeral of a sannyasi; but these ablutions serve instead of the bath which all Brahmins must take three times a day.

For ten successive days after the funeral the person who has presided thereat, and several other Brahmins in his company, meet every morning at the grave of the deceased to renew the offerings to the lingam. A similar ceremony takes place on the anniversary of his death.

The tombs of these sannyasis sometimes become famous, and crowds of devotees flock to them, bringing offerings and sacrifices as if to divine beings.

This custom did not die out in the $18^{\text {th }}$ and $19^{\text {th }}$ centuries, and continues today. ${ }^{602}$ More interesting for us at present is that this custom is already mentioned in

${ }^{602}$ Cp. Bouillier, 2004: 166 f. (“À Fatehpur, nous avons vu que le premier acte de tout nouveau mahant est d'ériger le samādhi de son prédécesseur. À l'emplacement même où Amritnāth mourut, ses disciples, Jyotināth en tête, creusèrent une fosse où ils 
connection with deceased samnyāsins in two para-vedic texts, the Baudhāyanapitṛmedha-sūtra and the Vaikhānasa Gṛhyasūtra, and in some more recent texts, among them the Smrtyarthasāra, which dates from around $1200 \mathrm{CE}$, and Yādava Prakāśa's Yatidharmasamuccaya, which dates from the eleventh century. Three of these four texts, the Vaikhānasa Grhyasūtra, the Smrtyarthasāra and the Yatidharmasamuccaya, state explicitly that there is no impurity associated with this custom. ${ }^{603}$

I have argued (Bronkhorst, 2007: esp. p. 85 ff.) that the samnyāsin more often called parivrājaka in the early texts - continues a tradition that originally belonged to Greater Magadha. This tradition was subsequently integrated into a brahmanical scheme. The samnyāsins mentioned in the texts just considered, including the account by Coeurdoux \& Dubois, were brahmanical renouncers, to be sure. But apparently these renouncers had preserved some peculiarities that do not at all fit in their new brahmanical surroundings, and which are most easily explained as survivals from their original milieu. In this original milieu there was no horror for dead bodies, no obsession with ritual purity, and a tendency to honour the mortal remains of people who had been held in respect. This was presumably the attitude to dead bodies that prevailed in Greater Magadha before the brahmanical obsession with ritual purity smothered it.

It is therefore possible to formulate the following hypothesis: The original funerary practices of Greater Magadha are behind a number of customs that have survived, most notably the relic and stūpa worship of Buddhists, Jainas and perhaps Ājīivikas, and the peculiar burial customs used for certain types of Hindu renouncers. The fact that these last customs are strongly represented in Nepal, where Muslims are relatively few in number and marginal, argues against the alternative hypothesis that these Hindu customs are mere imitations of originally Muslim ones.

l'enterrèrent assis, en position de méditation selon la tradition.") Kane, HistDh IV p. 229 : "A yati (sannyāsin) was and is even now buried." See further Briggs, 1938: $39 \mathrm{f}$.

${ }^{603}$ Bronkhorst, 2005: 56, with references; further Olivelle, 1995: $176 \mathrm{f}$., $380 \mathrm{f}$. 
This hypothesis sounds plausible enough. There is however an irritating difficulty: the samnyyāsin's body is not cremated. This suggests that cremation may not have been customary in Greater Magadha. ${ }^{604}$

What can we learn from vedic literature about funerary customs in Greater Magadha? The Śatapatha Brāhmaṇa passage considered earlier only criticizes the shape of the (round) sepulchral mound of its eastern neighbours; this does not help. A passage from the Chāndogya Upanișad states in so many words that the (followers of) the demons "adorn the body of someone who has died with offerings of food, with garments, and with ornaments" (ChānUp 8.8.5: pretasya śarīram bhikṣayā vasanenālañkāreṇeti saṃskurvanti). Among the few events recorded in surviving literature that correspond to this way of treating a dead body in early India, we must count the way in which the dead body of the Buddha was treated, before his cremation, by the inhabitants of a neighbouring town. ${ }^{605}$ These people, the Mallas, offer garlands of flowers, cloth, perfumes, music, dance, lights, etc., and go on doing so for seven days. ${ }^{606}$ John Strong (2004: 111) comments that such is not the usual way of conducting a funeral in India. Perhaps

${ }^{604}$ It is possible that in some cases, and from some date onward, attempts were made to preserve the dead bodies. The bodies of saints that have been placed in a so-called samädhi, to begin with, are often rumoured to be still there in the same state. More directly pertinent is the huge amount of salt (sometimes sugar) in which dead samnyāsins are covered. Salt desiccates the body and slows down its decay. This makes most sense if attempts were made to preserve the body of exceptional people, at least for some time. ${ }^{605}$ A comparable account has been handed down about the dead body of the jaina teacher Mahāvīra (see the Appendix to chapter III.7, below). Buddhist literature also mentions stūpa festivals, a phenomenon recently studied by Pagel (2007). Interestingly, there is an optional vedic rite that can be performed on a dead body, the antyestit that shares some of the same features. Sen (1978: 38-39), with references to the Bhäradvāja-pitrmedha-sūtra 1.4.1-2, says the following about it: "Antyesț - the last rite of a man, a part of the Pitrmedha rites. The dead body is taken out of the fire hall. Hair on his head and face are shaved, nails pared. The corpse is washed and adorned with new clothes, a garland of nalada flowers put around the head. The dead body is laid on an udumbara āsand $\bar{\imath}$ (couch) and tied to it, and covered with a new cloth. The belly of the corpse is cut open and the entrails are taken out, the faeces are squeezed out of the entrails, which is filled with sarpis and replaced in the belly. ... The funeral procession stops at 3 or 2 places. The carriers, who are servants or old men, lay down the dead body, place cooked rice on crushed clods (or kill a goat without a knife); the wives and kinsmen ruffle their hair, clap their right thighs, and fanning the corpse with the skirt of their garments they go round it 3 times in prasavya direction." Note further that the Mahābhärata (8.30.14-18) ascribes to the Bāhlīkas a similar behaviour: they laugh, sing and danse adorned with garlands, and their women danse while crying over their husband's death. ${ }^{606}$ Cp. Silk, 2006: 24 f. 
so, but what came to be the "usual way" does not have to have been usual at the time and in the region of the Buddha. Perhaps the Buddha was one of those whom the Chāndogya Upanișad calls the followers of the demons, just as the Śatapatha Brāhmana called the builders of stūpas demonic people. ${ }^{607}$ Let us leave this question in suspense for the moment and move on and consider another relevant issue, that of of conserving corpses in ancient India.

P. V. Kane (HistDh IV p. 233 f.) says the following about it:

Embalming the dead for some time at least was not quite unknown in India. The [Satyāṣạ̄ha Śrautasūtra] 29.4.29 and [Vaikhānasa Śrautasūtra] 31.23 prescribe that if an āhitāgni died away from his people his corpse should be laid down in a tub or trough filled with sesame oil and brought home in a cart. ${ }^{608}$ In the Rāmāyana it is several times said that the body of Daśaratha was placed for several days in a tub containing oil till the arrival of Bharata (vide Ayodhyā 66.14-16, 76.4 [= Rām 2.60.12-14; 2.70.4]). In the Viṣnu Purāna [4.5.7] it is stated that the body of Nimi being covered with oil and fragrant substances did not become decomposed and looked as if the death was recent.

All we can learn from these passages is that their authors had some ideas about how to preserve a dead body: in their opinion it has to be immersed in oil (taila), more precisely, in a tailadroñi, a tub filled with oil. These passages do not constitute evidence that embalming bodies in other than exceptional circumstances was an ancient brahmanical custom. Somewhat more suggestive is a passage in the Pāli Ariguttara Nikāya ${ }^{609}$ Here King Mụ̣da wishes to preserve the body of his beloved but deceased wife Bhaddā, and the method he proposes is immersion in an iron tub filled with oil (tela-doṇ $\vec{\imath}$. A buddhist monk talks him out of it.

\footnotetext{
${ }^{607}$ Buddhist stūpa worship, too, could be accompanied by flowers, garlands, etc., as well as music, song and dance, as is clear from the following passage from the

Saddharmapuṇdarīka Sūtra (Saddharmap(V) p. 145 1. 27-29): ... stūpe ... püjanā arcanā karañȳā sarvapuṣpadhūpagandhamālyavilepanacūrnacīvaracchatradhvajapatākāvaijayantībhih/ sarvagītavādyanrtyatūryatālāvacarasamgītisampravāditaih pūjā karan̄ìyā/. Hinüber (2009: 167) draws attention to a fragmentarily preserved inscription by Śīāditya I (around $600 \mathrm{CE}$ ) which, too, mentions music, song and dance as well as flowers and garlands in connection with worship.

${ }^{608}$ deśāntare mrtasya śarīram tailadronyām avadhāya śakațenāhare[t]; Caland, 1941: 312.

${ }^{609}$ AN III p. 57 f.; cp. Strong, 2004: 107 f.
} 
Let us now look again at the canonical accounts of the Buddha's funeral. ${ }^{610}$ The Buddha tells Ānanda, just before his death, that his dead body should be treated like the body of a world-ruler (cakravartin). It should be wrapped in a certain number of cotton cloths and then be put in an iron tub filled with oil. ${ }^{611}$ The expression here used — tailapūrṇa droṇī, Pāli teladoṇī — is identical with the one used in the different texts just considered. There the immersion into a tub full of oil served the purpose of preservation. Could it possibly serve the same purpose in the buddhist Mahāparinirvāna Sūtra as well?

The German scholar Ernst Waldschmidt was indeed of this opinion. ${ }^{612} \mathrm{He}$ pointed out that the dead body of the Buddha, according to the canonical accounts, was not cremated until seven days after his demise, so that it made sense to take measures to preserve it. The main weakness of this explanation is that, in the surviving account, the corpse of the Buddha was put into the tub after those seven days. In other words, the dead body of the Buddha had been preserved by unknown means before it was put in a bath of oil; it had not been preserved because of the bath of oil.

A second difficulty results from the fact that, when at last the cremation takes place, the corpse of the Buddha is not taken out of the tub with oil. In other words, the oil-filled tub, with the corpse of the Buddha in it, is put on the funeral pyre. This is problematic since, as the French scholar André Bareau observed, the body of the Buddha would in this way be deep-fried, like a fish in a pan, rather than being reduced to ashes. ${ }^{613}$

Bareau, who initially felt attracted to Waldschmidt's ideas, returned to the question in a more recent publication (1975). Here he suggested another explanation for the tub with oil. The extreme rarity of the use of this device to

\footnotetext{
${ }^{610}$ For recent discussions, see Strong, 2007; Hinüber, 2009a.

${ }^{611}$ Bareau, 1970-71: II: 35 f.; 1975: 155 f.

${ }^{612}$ Waldschmidt, 1944-1948: $263 \mathrm{f}$.

${ }^{613}$ Bareau, 1970-71: II: 43. Cp. Strong, 2004: 106 n. 21: "Upon being asked what would happen if a corpse were to be cremated in such a container as the taila-dronī, the director of a local crematorium ... said that, with the top on, there would be a risk of explosion, and with the top off, the corpse would basically get boiled in oil, which would result in a 'gross mess' (described as rendered fat with bones floating in it)." It must be admitted that the whole question is somewhat theoretical since, as Gérard Fussman points out in a private communication, one is not likely to find at short notice an iron tub in Kuśinagara around $400 \mathrm{BCE}$. If there was a tub, it was probably a hollowed out tree trunk.
} 
preserve a body, he proposes, had been misunderstood by the early followers of the Buddha to indicate excellence of the highest degree: only world-rulers and, of course, Buddhas would undergo this treatment after death. They therefore inserted the episode with the iron tub with oil into the story, even though it did not fit there at all.

Bareau's new explanation does not stand up to criticism either. It is, as a matter of fact, marred by a misunderstanding. This is due to a peculiarity of a work of scholarship on which Bareau bases his reflections. This work is the standard treatise on funeral practices in ancient India, Die Altindischen Todtenund Bestattungsgebräuche by W. Caland, published in 1896. Caland mentions the fact that an ähitāgni, i.e. a Brahmin who maintains the sacred fire, who has died in a foreign country can be taken back home in a tub full of oil. Unfortunately Caland does not support this with any references, no doubt as the result of an oversight. ${ }^{614}$ The Śrauta Sūtra passages considered above are not mentioned, nor are any other vedic, para-vedic or non-vedic passages. All we find in Caland's book is a reference to the case of Daśaratha. Bareau was obviously misled by Caland's oversight, concluding that this kind of treatment was reserved for kings and highly placed personalities. Had he known the Śrautasūtra passages that prescribe this treatment, he might not have drawn this conclusion, for these passages do not concern kings, but āhitāgnis, i.e. Brahmins who maintain the sacred fire.

We can yet agree with Bareau that the traditional accounts of the funeral events concerning the Buddha combine incompatible elements. Bareau's explanation is not plausible, as we have seen. Another explanation is however possible. It is conceivable that an earlier account of the events was subsequently modified, leaving some elements in the new account that no longer fit. According to this hypothesis, the initial account described the entombment, without cremation, of the Buddha into a stūpa. This event was then preceded by a period during which the corpse was preserved by immersing it in oil. Preservation of the body was necessary, presumably to provide enough time to build the stūpa. This initial account was subsequently changed. In the modified version the body of the

\footnotetext{
${ }^{614}$ Caland, 1896: $87 \mathrm{f}$.
} 
Buddha was cremated. However, it was no longer possible to remove the episode with the iron tub full of oil. It kept its place, in spite of having become an anomaly in the new story.

This hypothesis depends crucially on the absence of an assumption which Bareau took for granted. Bareau was sure that those accompanying the Buddha during and after his moment of death wished to execute the funerary rites in accordance with brahmanical custom, i.e. in agreement with the rules laid down in brahmanical texts. I do not share this assumption. The Buddha lived in an area that was not brahmanized, and which had its own customs in all domains, including that of the disposal of its dead. It follows that the temporary preservation of corpses in oil, though perhaps exceedingly rare in brahmanized areas, may have been more common in Greater Magadha. ${ }^{615}$ The composers of the initial accounts may have known what they were talking about.

At this point some crucial questions have to be asked: Why should the buddhist tradition have introduced such a radical change? Why should cremation be substituted for direct entombment? We might consider that ashes are less impure than a rotting corpse, but this may not suffice as an answer. ${ }^{616}$ A far more obvious answer is at hand: A non cremated, entombed human corpse requires one single stūpa, while ashes and isolated bones can be placed in large numbers of them. ${ }^{617}$ The Mahāparinirvāna Sūtra maintains that the relics of the Buddha were divided into eight portions that were placed in eight different stūpas. Later tradition holds that Emperor Aśoka made a further division of the bodily relics into $84^{\prime} 000$ portions that were placed in as many different stūpas. ${ }^{618}$ If the body of the Buddha had not been cremated, there could then be only one stūpa, and it

\footnotetext{
${ }^{615}$ The story of King Munda and his dead wife Bhaddā might lend some credence to this.

${ }^{616}$ This consideration may not suffice as an answer, but may have its role to play. Contemplation of rotting corpses became an important part of buddhist practice, a reminder of the unsatisfactory nature of existence. Imagining that the body of the Buddha had gone through all the phases of decomposition so vividly called up in this contemplation may have been more than what a pious Buddhist would feel comfortable with. On the "contemplation of the repulsive", see Dessein, forthcoming.

${ }^{617}$ Note however Ranade's (1933: 43) following observation with regard to samādhis: "It is not uncustomary among the Hindus to erect many different Samādhis in honour of the same person at different places, though the original and the most important Samādhi may be at one central place only."

${ }^{618}$ Strong, 1983: 109 ff.; 2004: 124 f.
} 
might have been impossible to put authentic bodily relics in large numbers of them.

Interestingly, the passage in which the Buddha tells Ānanda how his dead body must be dealt with speaks of just one stūpa. Does this mean that the Buddha was ignorant of the division of relics that would follow his death? It is hard to believe that his early followers believed that. They cannot have believed that the Buddha did not know what was to become the most popular form of buddhist worship everywhere, viz. the worship of relics in stūpas. The hypothesis I propose avoids this difficulty: it considers that the original account knew of only one stūpa, and that the uncremated body of the Buddha was placed in that stūpa after having been preserved in oil for a while.

In order to show how easily an earlier account without cremation could have been turned in one with cremation, I propose to look at one of the relevant parallel passages, this one from the Pāli Mahāparinibbāna Sutta, which seems fairly representative. Ānanda asks the Buddha how his body should be treated. ${ }^{619}$ The Buddha answers: just like the body of a world-ruler (cakkavatti, Skt. cakravartin). How is that? He explains: ${ }^{620}$

$\bar{A}$ nanda, the remains of a wheel-turning monarch are wrapped in a new linen-cloth. This they wrap in teased cotton wool, and this in a new cloth. Having done this five hundred times each, they enclose the king's body in an oil-vat of iron, which is covered with another iron pot. [...] They raise a stūpa at a crossroads. That, Ānanda, is what they do with the remains of a wheel-turning monarch, and they should deal with the Tathāgata's body in the same way. A stūpa should be erected at the crossroads for the Tathāgata.

We should not be disturbed by the exaggerations in this passage. Bareau has argued, on the basis of a comparison with parallels, that they are later additions. What does concern us is the line which I have skipped. It reads: "Then having made a funeral-pyre of all manner of perfumes they cremate the king's body." That is all. This little phrase may have been inserted. Or it may have replaced

\footnotetext{
${ }^{619}$ This passage speaks about the worship of the Buddha's body (sarīrapūjā, Skt. śarirapüjā), not about the worship of his bodily relics; see Schopen, 1991; Silk, 2006. ${ }^{620}$ DN II p. 141 f.; tr. Walshe, modified. Cp. Waldschmidt, 1950-1951: 360 f.; Silk, 2006: 9.
} 
something else, something that did not stand in the way of a smooth transition from immersing the body in oil and raising a stūpa. Of course, once this insertion or replacement was made, the remainder of the story was told in accordance with the now acquired conviction that the dead body of the Buddha had been cremated.

Essentially the same passage, this time with reference to King Mahāsudarśana, has been preserved in recently discovered Kharoṣthī fragments in Gāndhārī belonging to the so-called Schøyen collection. This passage is independent of any of its versions in Pāli, Sanskrit, Chinese and Tibetan, and this makes it particularly interesting for our purposes. This Gāndhārī version appears to preserve the memory that immersing in oil served the purpose of preservation, for the body of King Mahāsudarśana here undergoes that treatment twice over, in the following manner: ${ }^{621}$

... they put it in a vat .... After an interval of a week, they took (it) out of the vat of oil and bathed the body with all fragrant liquids .... They wrapped the body with (five) hundred pairs of (unbeaten) cloth. Having wrapped the body with five hundred pairs of unbeaten cloth, (they filled?) an iron vat with oil.... After building a pyre of (all) fragrant [woods], they burned the body of King Mahāsudarśana. They built a stūpa at the crossing of four main roads.

Suppose now that the hypothesis here presented is correct. In that case there would originally have been only one stūpa, containing the non-cremated bodily remains of the Buddha. The building of this stūpa might have taken some time, which would explain the need to preserve the dead body, presumably by immersing it in oil. Some of these features find unexpected confirmation in a passage preserved in a Chinese translation of the Mahäparinirvāna Sūtra and studied and analyzed by Bareau (1970-1971: II: 314-320). ${ }^{622}$ Bareau argues convincingly that this passage was composed independently and was only later inserted into the Sūtra. This passage is unaware of the division and distribution of the bodily relics of the Buddha, and speaks about their inclusion in one single stūpa, built not far from Kuśinagara, the village where the Buddha died. What is more, this passage speaks of a period of 90 days that separates the construction of

${ }^{621}$ Allon \& Salomon, 2000: 258; Salomon, 2001: 244.

${ }^{622}$ TI 5. 
the stūpa from the death of the Buddha. Bareau finds this tradition more plausible than the usual one, and wonders whether it may be closer to historical reality (p. 320). If our hypothesis is correct, it is closer to historical reality, or at least closer to the initial account claiming to describe it.

Let us at this point once more return to the tombs called samādhi in which Hindu renouncers are believed to reside in a state of yogic concentration. This belief is not altogether unknown to Buddhism. Mahākāśyapa, a disciple of the Buddha, is recorded in various texts to reside in such a state inside Mount Kukkutapāda in northern India, awaiting the time of the future Buddha Maitreya. John S. Strong (1992: 62 f.) presents the story as it occurs in various texts in the following words: ${ }^{623}$

Mahākāśyapa is ... ready to "die". After paying his last respects to the relics of the Buddha and sending word to King Ajātaśatru of his impending parinirvāna, he ascends Mount Kukkuțapāda near Rājagṛha and sits himself down between the three summits of that peak. There he makes a firm resolve that his body, his bowl, and his monastic robe (which had been given to him by the Buddha) should not decay after his parinirvāna, but should remain perfectly preserved inside Mount Kukkutapāda until the advent of the future Buddha Maitreya. Then he enters into the trance of cessation; the mountain-top opens up to receive him and miraculously encloses his body.

Unlike other buddhist saints, then, Mahākāśyapa does not autoincinerate his own body; nor is he to be cremated by others. Indeed, when King Ajātaśatru begins to gather firewood for a grand funeral, Ānanda stops him. "The Venerable Mahākāśyapa is not to be cremated!" he declares. "His body preserved in an ecstatic trance, he will await the arrival of Maitreya." And Ānanda describes how, in the distant future, the mountain will open up again and how Maitreya will show Mahākāśyapa's body to his disciples and receive (or take) from him the Buddha Śākyamuni's robe. In this way, Mahākāśyapa (or at least his body) is to act as a sort of link between two Buddhas - the last one and the next one and so as a kind of guarantee of the continuity of the Dharma.

What is not clear in this tradition is just when Mahākāśyapa is thought to attain parinirvāna. Is he alive inside the mountain in a deep meditative trance, from which he will emerge at the time of Maitreya? Or is he dead and only a sort of preserved mummy on which hangs the Buddha's robe?

Some texts seem to indicate the latter. Mahākāśyapa, they claim, attains parinirvāna before the mountain closes in on him. His body will

${ }^{623}$ Cp. Ray, 1994: 108 ff. 
remain preserved until the coming of Maitreya, but he will not then revive. Thus, in the Mūlasarvāstivāda Vinaya, Maitreya shows Mahākāśyapa's corpse to his disciples and displays to them the Buddha's robe, and they are filled with awe. Similarly, the "Maitreyāvadāna" (Divyāvadāna, chapter 3) speaks of Mahākāśyapa's "skeleton" (asthisaṃghāta) and describes how Maitreya will take it up "in the right hand, set it in his left, and teach the Dharma to his disciples".

Other texts, however, appear to indicate that Mahākāśyapa does remain alive in his mountain, in a meditative state of suspended animation. Hsüan-tsang, who visited the mountain in the seventh century, claims that, with Maitreya's arrival, Mahākāśsapa will emerge from his trance, perform his miracles, and only then pass into parinirvāna. The Mi le ta ch'eng fo ching adds some details to this scenario. It tells how Maitreya will first knock on the summit of Mahākāśyapa's peak and then open it "the way a cakravartin opens a city gate". The god Brahmā will then anoint Mahākāśyapa's head with divine oil, strike a gong, and blow the conch shell of the Dharma. This royal consecration will awaken the saint from his trance; he will get up, kneel down in front of Maitreya, and offer him the robe that the Buddha had confided to him. Only then will he enter parinirvāna, his body ablaze with flames. Another Maitreyist text, the Khotanese Maitreya samiti, describes a somewhat similar scene.

Mahākāśyapa, coming out of his trance, expresses his good fortune at having been able to meet two Buddhas personally, and then he launches into a long sermon explaining how the "leftover disciples", initiated but not brought to final Nirvāna by one Buddha, are usually saved by the next. He then displays his magical powers and enters parinirvāna.

I am not at all sure what can be concluded from this story. The parallelism with the entombment of Hindu saints in so-called samädhis seems evident. It is less obvious whether the story of Mahākāśyapa preserves a very ancient buddhist memory, or is rather evidence of external influence on Buddhism. It is in this context also interesting to remember that all the bodily remains of the earlier Buddha Kāśyapa (to be distinguished from the disciple Mahākāśyapa) were present in one single stūpa according to the Chinese pilgrims Faxian and Xuanzang. Other sources suggest that they are there in the form of a complete skeleton. ${ }^{624}$ Whatever the correct explanation of these two stories, they do not conflict with the hypothesis according to which the Buddha was not cremated. It may even lend some support to it.

In this context it is also interesting to mention a passage from a Vinaya text preserved in Chinese translation (TI 1463). Bareau refers to it in an article

${ }^{624}$ Strong, 2004: 33 f. 
(1962a: 230), drawing attention to a rule that stipulates that clothes should not be taken from a corpse placed in a stūpa. ${ }^{625}$ Bareau concludes from this, no doubt correctly, that this passage proves that inhumation was current in ancient India. It further shows that non incinerated corpses were put in stūpas or stūpa-like structures.

I cannot leave this topic without referring to a recent article by Peter Skilling (2005). ${ }^{626}$ In this article he draws attention to the fact that a variety of buddhist texts distinguish two types of relics, the second of which are what he calls solid ekaghana relics. These were supposedly left behind by certain Buddhas, and could not be divided into numerous parts. Having presented the rather extensive evidence for the existence of these two types, Skilling poses some questions in the following passage (p. 302):

Why did the theory of the two types of relics develop? What function did it serve? It seems that from the beginning - and before the conscious classifications were developed - the relics of Śākyamuni were believed to be fragmentary, since they were divided into eight portions, and later further distributed by Aśoka the Great into 84,000 stūpas. Since the early spread of Buddhism was also a spread of relics and stūpas, there was a constant need for relics, and for an ideology that explained their significance. ... But what was the function of the solid ekaghana relics? Can the belief in solid relics itself be a trace of an earlier or alternative belief?

Skilling explores some further possibilities, but I will not cite these. His question whether the belief in solid relics can be a trace of an earlier belief is particularly relevant in the context of our present reflections. Indeed, it would agree with our hypothesis. This hypothesis, if correct, would also oblige us to reconsider the statement according to which the relics of Sākyamuni were believed to be fragmentary from the beginning. They were no doubt from an early date onward, but perhaps not quite from the beginning, and the belief in solid relics might conceivably be a trace of an earlier period during which even the bodily remains of Śākyamuni were not yet believed to be divided up into numerous parts.

625 “ $\mathrm{Si}$, à l'intérieur du tertre, le cadavre n'est pas encore détruit, les vêtements qui sont sur le cadavre ne doivent pas être pris."

${ }^{626}$ Cf. Silk, 2006: 85 f. 
I am not going to press the hypothesis just presented. It is obviously hazardous to propose alternatives in cases where the historical sources are almost unanimous. ${ }^{627}$ All buddhist traditions maintain that the Buddha's body was cremated after his death, so alternative hypotheses need to be supported by strong evidence indeed. Peter Flügel (2010: 463, n. 197), moreover, rightly points out that there is no evidence for jaina and àjīvika burial practices in early India. ${ }^{628} \mathrm{We}$ might add that there is no evidence for buddhist burial practices in ancient India either.

Having said this, it is yet important to point out that the story of the cremation of the Buddha's body plays a crucial role in the justification of the cult of relics that came to be a central feature of Buddhism. ${ }^{629}$ It is therefore more than understandable that pious Buddhists were almost obliged to invent it if it was not already part of the oldest tradition.

Let us at this point recall what exactly we are discussing. We are discussing the earliest accessible account of what happened to the lifeless body of the Buddha. This earliest account does not necessarily tell us something about what really happened. The sometimes fantastic accounts which we find in the Mahāparinirvāna Sūtra and parallel texts may be the outcome of much editorial activity. ${ }^{630}$ Perhaps these accounts allow us to reconstruct the earlier account from

\footnotetext{
${ }^{627}$ Not fully, as we have seen. John S. Strong (2007) draws attention to a number of passages (among them those we have considered above) to show that there are two Buddha relic traditions represented in the surviving literature.

${ }^{628}$ Flügel's other comments are less helpful, for he asks for reasons and explanations in an area in which reasons and explanations are difficult to find, and the best one can hope for is a more or less coherent and satisfactory hypothesis.

${ }^{629}$ Strong, 2007: 50.

${ }^{630}$ This in spite of the fact that the event of the death of the Buddha "was, if any, very present in the collective memory of the early community and when the text[s] were composed" (Hinüber, 2008: 22). The Buddha's prediction about Pātaliputra in this text, moreover, may allow us "to conclude that this is a very old part of the text, dating to a time, when Pătaliputta was a town of commercial, but not yet of political consequence, that is before Candragupta" (Hinüber, 2009a: 63). If one accepts that "it is hard to avoid the conclusion that during the lifetime of the Buddha the Buddhists had an order of monks only and that this is exactly the situation as reflected in the suttantas" (Hinüber, 2008: 24, also 2009b: $147 \mathrm{ff}$.), and keeps in mind that according to all versions "when the Buddha dies, no nun is present, only monks and gods" (p. 22), it is tempting to conclude that the order of nuns was created after the reworking of the account of the Buddha's demise.
} 
which they all derived, but the historical reliability of this earlier account is not guaranteed either. ${ }^{631}$ The hypothesis I have presented concerns an account that is presumably older than the one underlying those that have come down to us. ${ }^{632}$ Here again, its historical reliability is not guaranteed. What really happened to the body of the Buddha after his death is likely to remain forever unknown to us, and was perhaps unknown to those who created the different accounts. There is however one major difference between them and us. We may consider that the Buddha died in a forgotten corner of northern India, with few noticing except some of his most devoted pupils. For the creators of the buddhist tradition such a scenario was unimaginable. For them, the Buddha was as great as, if not greater than the greatest king, and his death could not but have been the occasion for elaborate celebratory activity. They told the story the way they were convinced it had to have been, and this is the story which became the basis for further elaborations and, perhaps, modifications.

Appendix to chapter III.7: What happened to Mahāvīra's body? ${ }^{633}$

Jainism has its stūpas, but their role is mysterious. Did they contain relics, of Mahāvīra or other saints? About relics in Jainism, Dundas states the following (2002: 219):

The origin of Jain holy places did not stem from the worship of relics, as seems to have been partly the case with early buddhist pilgrimage sites. The remains of the Buddha's body were, after cremation, supposedly

\footnotetext{
${ }^{631}$ Note that Oskar von Hinüber (2009a: 64) is less pessimistic: "With a little bit of optimism it can be assumed that the core of the report as given in the Mahāparinibbānasuttanta is not totally different from what happened at the death of the Buddha." He bases this optimism on a number of reflections, among them the following: "if it is kept in mind that it is likely that the Buddha died in about $380 \mathrm{BC}$, there is a bracket of approximately 60 years between the event and the text formulated, if one dares to be so explicit."

${ }^{632}$ This would be all the more remarkable if — as Oskar von Hinüber (2008a, esp. p. 204) has argued - parts of the Mahāparinirvāna Sütra may have been composed before the establishment of the Maurya empire.

${ }^{633}$ This Appendix is indebted to Dr. Bansidhar Bhatt, who was kind enough to make suggestions.
} 
distributed throughout the Ganges basin, whereas the traditional accounts of Mahāvīra's funeral describe how his bone relics were collected together by Indra and taken to heaven where they were worshipped by the gods ...

Dundas refers in this connection to Hemacandra's Yogaśāstra $(1.8 .67=$ vol. I p. 40), a text composed some fifteen centuries after the event. ${ }^{634}$ We learn from Schubring (2000: 26-27) — who refers in this connection to the canonical Jambuddīvapannatti, an Upānga text - that the cremation of the corpse of a tīrthankkara, any tīrthankara, is performed by all godly princes under Sakka's, i.e. Indra's, leadership. ${ }^{635}$ Schubring refers to the Viyāhapannatti (p. 502b) to add that the relics of tìrthaikkaras enjoy adoration in the heavenly sphere. Elsewhere in his book (p. 49-50) he states:

In the course of its most detailed description of a godly residence [the] Rāyap[asenaijja] refers to 4 sitting Jina figures ... of natural size surrounding a stūpa towards which they turn their faces, adding that a special building ... contains 108 [effigies of the Jinas] j[ina]-padimā. Their cult on the part of the god equals that of to-day consisting in the attendance of the figures by uttering devotional formulae. In the large hall (sabha), however, there are spherical boxes (gola-vatta-samugga) containing the sacred remains (j[ina]-sakahā ...) and hanging on hooks (nägadanta) by means of cords (sikkaga). The whole description most certainly follows earthly examples.

What should we conclude from all this? Did the early Jainas worship relics, among these relics of Mahāvīra, or did they not? W. J. Johnson (2003: 224) thinks they did:

Although later jaina tradition suggests that Mahāvīra's relics were whisked away by the gods, ... it is difficult to imagine that Jain stūpas were viewed simply as memorials, devoid of relics.

\footnotetext{
${ }^{634}$ Flügel (2010a: 435) draws attention to the most famous depiction of jaina relicworship in the first book of Hemacandra's Trișaștiśalākāpuruṣacaritra (I.6.459-643) which, he points out, is largely based on earlier canonical accounts in the

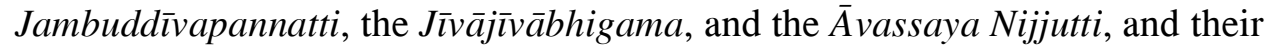
commentaries. It may be significant that Hemacandra uses the term ratnastūpa (v. 562) where the Jambuddīvapannatti has stūpa (thübha). See also Cort, 2010: $121 \mathrm{ff}$. ${ }^{635}$ Schubring refers here to p. $156 \mathrm{~b}$ of the edition used by him, which is not accessible to me. See however below.
} 
Early jaina literature frequently mentions stūpas, and archaeology has revealed an ancient stūpa in Mathurā which is identified as jaina. ${ }^{636}$ Dundas, who decried the role of relics in Jainism in the passage considered above, is slightly embarrassed by the stūpa in Mathurā (2002: 291 n. 4; cp. 2006: 400):

The function of the stūpa at Mathurā has not been adequately explained, since relic worship has never been a significant component of Jainism, as it has in Buddhism. Nonetheless, it does seem that this early stuppa was in some way involved in commemoration of the dead.

A recent article by Peter Flügel (2008) sheds additional light on the tradition of stūpas and relic-worship in Jainism. Flügel states here (p. 18):

[R] esearch in 2000-2001 produced the first documentation of two modern Jain bone relic stūpas, a samādhi-mandira and a smäraka, constructed by the Terāpanth Śvetāmbara Jains. Subsequent fieldwork demonstrated that relic stūpas are not only a feature of the aniconic Jain traditions ..., but also of Mūrtipūjaka ... and Digambara traditions. Hence, the initial hypothesis that the contemporary Jain cult of bone relics functions either as substitute or as a prototype for image-worship had to be amended.

In an even more recent article he states (Flügel, 2010a: 410):

Publicly, the members of the Jaina community are in collective "denial" about the widespread practice of relic veneration, and it is only due to favourable circumstances if this dimension of the Jaina "cultural unconscious" can occasionally be unveiled.

This recent discovery does not solve the problem of the secondary role which stūpas and relic-worship play in Jainism; in a way it only deepens it. The inescapable question is: if stūpas played any role at all in Jainism, why then did stūpa and relic worship not develop here the way they did in Buddhism? In Buddhism, we all know, the tradition preserved in great detail the memory of what happened to the body of the Buddha, whereas in Jainism we only find late stories about the worship of the Jina's mortal remains by gods, preferably in heaven. Why this difference?

${ }^{636}$ Smith, 1900; Quintanilla, 2007: 38 f., 50; Cort, 2010: 29 f. 
At this point it will be useful to take into consideration our reflections about what happened to the dead body of the Buddha. We saw there that the presumed incineration and division of the Buddha's body constitute the necessary background for the cult of relics in stūpas that came to characterize Buddhism in all of its forms. In other words, if the story about what happened to the Buddha's body is historically unreliable, it is clear why it had to be invented. Without widespread relics, there can be no wide-spread relic-worship. Is it possible that a similar kind of reasoning should be applied to Jainism, which did not emphasize relic-worship? Is it possible that Jainism invented a tradition that justified the absence of relic-worship that came to install itself in this tradition?

Let us turn to the oldest and paradigmatic account of the disposal of the body of the tìrthankara Rṣabhadeva in the Jambuddīvapannatti (2.89-120; pp. 390-394). It is presumably applicable to all tīrthankkaras, including therefore Mahāvīra. It tells us that soon after his demise, Śakra and many other gods carried out a number of deeds, among them the following:

1) To begin with three funeral pyres (ciyag $\bar{a})$ are built out of fragrant sandal wood: one for the tìrthankara, one for the ganadharas, one for other houseless monks (anagāra). (It is to be noted that these ganadharas and houseless monks had died through sallekhanā at the occasion of the death of the tirthaikara.) (2.95-96)

2) Milk-water (khīrodaga) is collected from the Milk-water Ocean and used to bathe the dead body of the tîrthankara, which is subsequently anointed, wrapped in cloth, and adorned with all manner of ornaments. The same happens to the dead bodies of the ganadharas and houseless monks. (2.97-100)

3) A palanquin is constructed, the dead body of the tìrthankara is lifted onto it, and the palanquin is put onto the funeral pyre. Two further palanquins are constructed, one for the ganadharas and one for the houseless monks. (2.101104)

4) Fire and wind are then made to do their job. The fire is subsequently extinguished. For each constituent event the tìrthankara, the ganadharas and the houseless monks are mentioned, altogether eight times. (2.105-112) 
5) Different parts of the body of the tìrthaikara are taken by various gods, to begin with Śakra. No mention is made of ganadharas and houseless monks.

6) Three stūpas (ceiyathūbha = cetiyastūpa) are built: one for the tīrthainkara, one for the ganadharas, one for the houseless monks. (2.114-115)

7) Having performed various festivals (mahima), the gods return home. Once back, they put the bones of the Jina in round boxes (golavattasamugga), which they then worship. No ganadharas and houseless monks are mentioned. (2.116120)

What strikes the eye is that all but two of these seven episodes deal with one tìrthankara, and several ganadharas and houseless monks who have taken their lives by way of sallekhanā. Two of the episodes do not include these ganadharas and houseless monks; these two, nos. 5 and 7, deal with bodily relics of the tirthankara. This suggests that these two episodes were inserted in a text that did not deal with bodily relics of the tîrthaikara. In other words, there may have been an account in which the tìrthankara and his companions were cremated and put into stūpas, and no bodily relics were taken, neither by the gods nor by anyone else.

This impression is strengthened by the fact that the episodes that deal with all three types of saints end with the construction of stūpas for all of them: one for the tirthankara, one for the ganadharas, one for the houseless monks. What these stūpas were good for is not stated, and indeed, the presumably inserted episode reporting the disappearance of the bodily relics of the tirthankara to heavenly realms would make us think that these stūpas — or at any rate the stūpa built for the tìrthankara - served no purpose whatsoever. ${ }^{637}$ The plausible conclusion to be drawn is that there was an earlier account in which the bodily remains of the tīrthankkara were all put in a stūpa, one stūpa, those of the ganadharas in another, and those of the other liberated houseless monks in a third one. However, this original account was modified by the substitution of two episodes claiming that the bodily relics of the Jina had been taken to heaven.

${ }^{637}$ Calling them commemorative stūpas is of course only a trick to avoid the issue. 
Independent evidence that further strengthens this conclusion is constituted by the fact, pointed out by Flügel (2010a: 435 n. 113), that most Digambara accounts of R̦sabha's funeral differ from the Jambuddivapannatti in that they do not mention bone relics, and omit the episode of the removal of the relics by the gods. Flügel refers in this connection to the jaina Ādi Purāna (47.343-354).

The reason for the rather clumsy modification of the passage in the Jambuddivapannatti is easy to see, and is the mirror image of the reason that presumably led the Buddhists to modify their story of the post-mortem destiny of the Buddha's body. In the case of Buddhism, the story of the large-scale distribution of relics from the Buddha's body justified the wide-spread stūpa worship that characterizes that religion. In the case of Jainism, the disappearance of the bodily relics of the Jina justifies the absence of their worship. In both cases we may guess that the whereabouts of the original relics were unknown to the later tradition. If so, both traditions were confronted with a similar problem. The way they resolved it was however quite different. Buddhism invented a story which allowed its followers to believe that there were authentic bodily relics in most if not all buddhist stūpas. Jainism presented a story which convinced its followers that there were no authentic bodily relics of tìrthankaras to be found on earth, because they had all be taken to heaven. ${ }^{638}$

One more question has to be dealt with. Even the "authentic" part of the story in the Jambuddivapannatti maintains that the body of the Jina was cremated. In the case of Buddhism, we had been led to consider that the body of the Buddha had perhaps not been cremated, but had been put in a stūpa without undergoing this treatment. Should we not expect the same in the case of a Jina? Perhaps we should. It is therefore appropriate to remember that the Jambuddivapannatti is not a very early text; Flügel (2010a: 432) dates it between the first and fifth century $\mathrm{CE}$, and Bansidhar Bhatt, in a private communication, informs me that in his

\footnotetext{
${ }^{638}$ The bones of Jinas (jina-sakahā), kept in globular diamond reliquaries (gola-vattasamugga) in a stūpa (ceiya-khambha) in heaven (or more precisely, in the residence of the god Camara) are also mentioned in the Viyāhapannatti; see Deleu, 1970: 171.
} 
opinion it cannot be put earlier than the $2^{\text {nd }}$ century $\mathrm{CE} .{ }^{639}$ What is more, Flügel (2010a: 433) argues that "the practice of cremating the discarded bodies of ascetics, and preserving relics, performed by householders (Jaina laity or the general public), was either introduced in the middle- or late-canonical period, or always existed side-by-side with the monastic custom of simply abandoning the body". In other words, it is possible that the body of the Jina was not cremated. Perhaps we should add that it may have been discarded the way the bodies of other jaina ascetics were apparently discarded in the early jaina tradition.

Returning now to the Jambuddivvapannatti, I would argue that it allows us to think of three succeeding periods:

1) We know nothing about what happened to the dead body of the Jina, except that it was probably not cremated; given that building stūpas and stūpalike structures for at least certain dead people was a custom in Mahāvīra's region which is already attested in the Śatapatha Brāhmana, it is possible that his corpse was put into a stūpa, but we cannot exclude that it was abandoned in nature.

2) For reasons that we do not know for certain but that we may plausibly guess (considerations of purity, newly acquired cultural propriety) the claim was made that the corpse of the Jina had been cremated before being put into a stūpa. This is recounted in the story of the Jambuddivapannatti, minus its insertions.

3) Additions were made to this story, claiming that the relics had been taken away by the gods. This left an incoherent story and an empty stūpa, but presumably suited the tastes of those who made the changes. The practical consequence of these changes was that the worship of Mahāvīra's relics (or of the relics of any other tīrthainkara for that matter), though theoretically still respectable, was banished from the tradition.

\footnotetext{
${ }^{639}$ Kirfel (1924) has shown that the Jambuddīvapannatti and the Dìvasägarapannatti which according to the Thannanga once had independent existence before being incorporated in the jaina canon (Schubring, 2000: 98) - derived from a single earlier text. The portion to be considered below has no parallel in the Divvasāgarapannatti, which suggests that it may have been added later.
} 


\section{III.8 Adjustment to political reality}

Preceding chapters have drawn attention to the unequal competition Buddhism in India had to face from the side of Brahmanism. True, Buddhism was not without strong points, and this no doubt explains that it could hold its own for many centuries against the brahmanical threat. It was however at a disadvantage in that it had fewer means of influencing the centres of political power. Indeed, Buddhists had largely given up on trying to offer political counsel to kings, leaving this field to Brahmins. Buddhists were good at debating, to be sure, but the things they wanted to debate about were far too abstract for all but a minority of rulers, and provided in any case no support to the kingly task of ruling a country.

The difficulty, as we have seen, was that Buddhism found it difficult to present a picture of and a justification for a society in which there was place for real kings and realistic policy. ${ }^{640}$ Worse, Buddhism did not have much place for positions people might occupy in society outside the monastery. It concentrated on encouraging people to become monks and nuns. Failing this, it encouraged them to become lay followers - upāsakas or upāsikās — but the obligations it imposed upon them, and the further vows which these lay followers were more or less expected to make, put them in a category quite distinct from the ordinary

\footnotetext{
${ }^{640}$ The Jainas, here as elsewhere, adjusted more easily, as may be clear from the following (Flügel, 2007: 3-4): "Jaina texts on kingship, statecraft and personal law were composed in contexts where individual Jaina mendicants exercised personal influence over one or other 'Hindu' king or local official. The majority of the texts were created by monks of the Digambara tradition which had a sustained influence on the ruling dynasties in the Deccan between the $8^{\text {th }}$ and $12^{\text {th }}$ centuries. The most significant jaina works on statecraft are the Ādi Purāna of Ācārya Jinasena (ca. 770-850 CE) and the Nütivākyāmrtam (ca. 950 CE) and the Yaśastilaka (959 CE) of Ācārya Somadeva Sūri. Both authors were associated with the rulers of the Rāṣtrakūṭa empire. The Ādi Purạna belongs to the genre of universal history. It tells the life story of the first Jina, the legendary first king and law-giver Rṣabha, in the manner of a jaina Mahäbhärata, and for the first time offers blueprints for Jain social rituals and Jain kingship through the Jainization of Brāhmanical prototypes. The Nìtivākyammrtam, by contrast, is an entirely secular text on statecraft modelled on the Arthaśāstra of Kautilya (ca. 3rd century BCE 1st century CE) with barely noticeable emphasis on jaina morality." This last text "barely shows any Jain traits at all" (Dundas, 1991: 176).
} 
citizen and excluded them from many occupations. ${ }^{641}$ For others, most notably those involved in governing the country, Buddhism had but little advice. ${ }^{642}$ Those others should somehow fit into the dominant vision of society, that of the Brahmins. As long as Buddhism had nothing of its own on offer, it could not but accept that vision, no doubt with regrets. The pressure to come up with something more satisfactory must have been great. It led to developments which we will now briefly consider.

We have had occasion to mention the Jātakas. Their interest goes well beyond that of being buddhist stories. They are stories that tell what the most recent Buddha had gone through and done in earlier lives. These deeds had contributed to his ultimate victory, that of becoming a Buddha. However, the most recent Buddha is not the only Buddha there has been, or will be. Already in canonical times, Buddhists had come to believe that there had been Buddhas before the most recent one, and that there will be others in the future. Obviously, the highest aim these Buddhists could aspire to was that of becoming a Buddha themselves. This aim, they thought, was to be preferred to the simpler and more self-centred one of becoming an enlightened arhat. Some of these Buddhists actually made a resolve to become a Buddha. This resolve is known by the name

${ }^{641}$ La Vallée Poussin, 1925; 1927: 47 f. One early Sūtra that concerns primarily lay behaviour is the Sikhālaka Sūtra / Singālovāda Sutta. Hartmann and Wille (2006: 1) say the following about it: "The sermon to the layman Śikhālaka — this is his name in the Sanskrit version - or to Sigālaka/Singāla, as he is called in the Pāli sources, ranks among the best-known discourses of the Buddha, since it is famous for containing all the fundamentals of the ethics of a buddhist lay person. Consequently, every school we know of incorporated a version of this discourse in their collection of canonical scriptures." Buddhaghosa calls this sermon "Vinaya for householders" (gihi-vinaya; Freiberger, 2000: 197). For a discussion of Theravāda texts on lay behaviour, see Crosby, 2006. See further Agostini, 2008; Choong, forthcoming. Paul Harrison (1995) proposes, on the basis of early Mahāyāna Sūtras, a fourfold division of buddhist lay followers, ranging from "semi-ordained lay practitioners" to such as barely pay attention to Buddhism; cf. Freiberger, 2000: $144 \mathrm{ff}$.

${ }^{642}$ Jaini (1980: 84 [144]) draws attention to the relative neglect of lay people in Buddhism as compared with Jainism: "The Jainas ... eventually produced some fifty texts on conduct proper to a jaina lay person (śrāvakācāra), while the Buddhists, as far as we know, managed only one (and that not until the eleventh century)." On jaina lay people, see further Norman, 1991 and Williams, 1963. For lay people as depicted in a number of early buddhist texts, see Freiberger, 2000: ch. 4 ("Der Orden und die Laienanhänger"). 
bodhicitta ${ }^{643}$ Those who have generated it are henceforth Bodhisattvas, future Buddhas. ${ }^{644}$ These new Bodhisattvas drew inspiration from the Jātakas and tried to imitate the deeds they recount to the extent possible. ${ }^{645}$ This in its turn had interesting consequences, among them the following: a serious and committed Buddhist did not have to be a monk, he might stay in society and play a role in it, just as the most recent Buddha had occupied various positions in society in earlier lives.

This last point is illustrated in an early Mahāyāna text, The Inquiry of Ugra (Ugrapariprccha $)$. Half of this text gives advice to householder Bodhisattvas.

Among the many pieces of advice we find the following: ${ }^{646}$

The householder Bodhisattva seeks wealth according to the Dharma; he does not seek it according to what is non-Dharmic. He seeks it fairly, not unfairly. He pursues right livelihood, not wrong livelihood. ... not desiring happiness for himself, he causes all beings to attain happiness. Unmoved by profit or loss, fame or infamy, praise or blame, happiness or suffering, he transcends worldly things. He does not become arrogant because of amassing profit and wealth, nor is he discouraged by the absence of profit, fame, or praise. ... With respect to his undertakings, he is firm in his sense of obligation.

Furthermore: ${ }^{647}$

The householder Bodhisattva who lives at home, by being free of attachment and aversion, should attain equanimity with respect to the eight worldly things. If he succeeds in obtaining wealth, or a wife, or children, or valuables, or produce, he should not become proud or overjoyed. And if he fails to obtain all these things, he should not be downcast or distressed.

Note that the householder Bodhisattva depicted in this text passes his time seeking wealth. It is true that there are limits to the methods he can use in doing

\footnotetext{
${ }^{643}$ Wangchuk, 2007.

${ }^{644}$ Fujita (2009) shows that also in schools that did not belong to the Mahāyāna, such as Sarvāstivāda, ordinary sentient beings could aspire to becoming a Buddha, and therefore become Bodhisattvas.

${ }^{645}$ See Boucher, 2008: 20 ff. ("Former life narratives and the Bodhisattva career").

Jātakas also inspired people who did not wish to become Buddhas themselves, perhaps already at a time when the Bodhisattva-ideal did not yet exist; see Walters, 1997: 166. ${ }^{646}$ Nattier, 2003: 223, 225, 226.

${ }^{647}$ Nattier, 2003: 246.
} 
so, but as long as he observes these, he can participate in economic life. He can also marry and have children, that is to say, participate in ordinary social life.

Let me emphasize the importance of this development. Buddhism had from the beginning presented itself as a path leading to the end of suffering and rebirth. This path consisted in saying farewell to the world and dedicating oneself to the spiritual practices taught by the Buddha. Monks and nuns actually did so (or were supposed to do so), ${ }^{648}$ upāsakas and upāsikās did so to a considerable degree. Those who did not do so and remained in the world had an ill-defined position in the buddhist scheme of things. They might feel sympathetic toward the buddhist teaching and community, but it was not clear whether and to what extent they could be thought of as partaking in the buddhist path.

Non-monastic Buddhists could not forever remain in limbo. They found a place for themselves by laying stress on the importance of accumulating merit. Recall what, according to authors like Nāgārjuna, one had to do in order to become a Universal Monarch. The answer is: acquire merit. One verse spells out what kind of merit is meant: "Through proper honouring of stūpas, honourable beings, Superiors, and the elderly, you will become a Universal Monarch, your glorious hands and feet marked with [a design of] wheels." In other words, accumulating merit is the most secure way to acquire a kingdom, or whatever else one wishes to acquire in a future life. The Jātakas show that accumulating merit is also essential for reaching the highest aim there is, that of becoming a Buddha. Innumerable inscriptions confirm that the advice to accumulate merit was taken to heart by rulers and subjects, by monastics and lay people alike.

If we now return to the Jâtakas, it will be clear that these stories could become examples of ideal behaviour for all those who wished to increase their stock of merit, including those who had not decided to become Buddhas themselves. These stories often emphasize the generous or compassionate aspect

${ }^{648}$ Cf. Schopen, 2006b: 225: "To judge by the buddhist monastic literature that has come down to us, it seems almost certain that the typical buddhist monk from the period around the beginning of the Common Era would hardly recognize himself in the romantic characterization — or caricature — of him that is, unfortunately, still all too current. This typical monk - again, to judge by the literature that monks themselves wrote and, presumably, read - almost certainly did not wander alone in the forest cut off from all social interaction, nor spend much time meditating at the root of a tree. He almost certainly would have been far too busy." 
of this or that earlier incarnation of the Buddha. But they do more. They show that one can be a totally committed Buddhist, even a future Buddha, while yet continuing to occupy a role in society. Living in the world is compatible with being a Buddhist in the strictest sense of the term. But living in the world also means living in accordance with the norms of society. Depending on the position one occupies in it, one may even be obliged to kill. In this way, the question that must have occupied many Buddhists, viz. "Can one be a Buddhist and live in society?", found its most poignant expression in the question "Can one be a Bodhisattva and kill?" This last question is discussed in a number of texts belonging to the movement that was particularly interested in the careers of Bodhisattvas, and which came to be known as the Bodhisattva-yāna or Mahāyāna. ${ }^{649}$ Not surprisingly, this issue raises a number of questions, for example about the state of mind of the Bodhisattva and that of his victim while the former kills the latter. ${ }^{650}$

Related to the question of killing is the one whether war is ever justified. The Mahāyāna Mahāparinirvāna Sūtra states in so many words that lay Buddhists must protect buddhist teaching, if necessary with the help of arms. It further states that killing certain people — those who reject Mahāyāna and adhere to particularly unwholesome views and practices — is less bad than killing animals; what is more, it constitutes no infringement of the prohibition to kill. ${ }^{651}$ Enemies of Buddhism, the Sarvadurgatipariśodhana Tantra adds, should be killed where

\footnotetext{
${ }^{649}$ It may be useful to recall Skilling's (2005: 270 f.) recent observation that Śrāvakayāna and Mahāyāna are "[t]wo of the most overworked categories in buddhist studies": "we have reified the categories and treated Śrāvakayāna and Mahāyāna as discrete historical agents and movements, when they are meant to describe related processes of intellectual interaction, often intense dialogue and debate, within a single (but infinitely variable) imagination, Buddhism. The categories are meant to provide a background, to help us sort out our data, but they have marched on to the stage and taken over the show." It is further important to note that the terms Bodhisattva-yāna and Mahā-yāna are not altogether equivalent; see Fujita, 2009: 114; and Walser, 2009 for the origin of the term "Mahāyāna". For different types of Bodhisattas in the Theravādin tradition, see Skilling, 2009: $90 \mathrm{ff}$. On the different positions within Mahāyāna on the desirability or otherwise of wilderness dwelling, see Boucher, 2008: $40 \mathrm{ff}$.

${ }^{650}$ See Schmithausen, 2007; 1996: 76 f.; 1999: 59. See further Kleine, 2003: $246 \mathrm{f}$.

${ }^{651}$ Schmithausen, 1996: 75; 1999: 57 f. The Mahāyāna Añgulimālīya Sūtra expresses itself similarly; Schmithausen, 2003.
} 
possible. ${ }^{652}$ The Bodhisattvabhümi points out that a Bodhisattva who is king commits a serious transgression if he does not threaten severe punishment in order to impose virtuous behaviour on his subjects, even against their will. ${ }^{653}$

In order to show that not only Mahāyāna Buddhists were concerned with the question of killing other human beings, let me refer to a passage from the (Theravāda) Mahāvaṃsa (25.109-110). It tells us about the remorse of King Dutṭhagāmaṇi Abhaya over the death of numerous warriors killed in his victory over the Damila King Elāara. At this point eight arhats come to comfort him. They do so in the following words: "From this deed arises no hindrance in the way to heaven. Only one and a half human beings have been slain here by thee, $\mathrm{O}$ Lord of Men. The one had come unto the [three] refuges, the other had taken on himself the five precepts. Unbelievers (micchäditthi) and men of evil life were the rest, not more to be esteemed than beasts." ${ }^{954}$ This breathes the same spirit as the passage from the Sarvadurgatipariśodhana Tantra referred to above.

Once Buddhism had resolved the issue of how one could be a layman in society and yet be counted as a devout Buddhist, its competition with Brahmanism took a different shape. Brahmanism had always had the great advantage of being able to counsel political rulers in a most practical fashion. It had been able to assure those rulers that the violence they sometimes had to commit was in keeping with their position in society and was indeed part of their duty. Now that the Buddhists had come to realize that the Buddha himself had been king in earlier existences, ${ }^{65}$ and had competently ruled the kingdoms he had been in charge of, they could no longer blame present rulers for carrying out their task using the means required. This opened up new possibilities. They might henceforth aspire to the position of royal counsellor in political matters, just as the Brahmins had done so far. ${ }^{656}$

\footnotetext{
${ }^{652}$ Schmithausen, 1996: 76; 1999: 58; Skorupski, 1983: 66, 218.

${ }^{653}$ Schmithausen, 2003: $42 \mathrm{f}$.

${ }^{654}$ Jaini, 2007: 154, who cites Geiger's translation.

${ }^{655}$ Many hundreds of times the Buddha had been a universal ruler (rāja $\operatorname{c}$ cakkavattī), already according to the Anguttara Nikāya (AN IV p. 89).

${ }^{656}$ Note that "the Rājadharma-nyāya-śāstra, part of the massive Yogācārabhūmiśāstra ascribed to Maitreya and Asanga (early centuries A.D.), puts kingship into the larger scheme of a Bodhisattva's development as accepted by the Yogācāra school; it strongly
} 
A beautiful example of a buddhist minister who justifies the kingship of his ruler in buddhist terms comes from the kingdom of Ankor, in present-day Cambodia. ${ }^{67}$ The ruler concerned is Jayavarman V, who ruled from 968 to 1001 CE. From his realm a considerable number of inscriptions have been preserved, one of which, the so-called Vat-Sithor inscription, merits our attention. The buddhist minister called Kīrtipaṇitita figures prominently in this inscription, which contains some buddhist propaganda. For our present purposes it is most interesting that both the king and his minister Kīrtipandita are characterized as Bodhisattvas, whose deeds are guided by the unique concern to lead their subjects to heaven and liberation. What the king expects from his subjects, moreover, is in agreement with the true teaching (dharma, saddharma) of the Buddha, and conducts his subjects to better rebirths and liberation.

Rulers could compare themselves to Bodhisattvas, or even to a Buddha. The Pāla ruler Devapāla, when he gained the throne, repeatedly stated that he did so as a Bodhisattva obtains the position of a Buddha, following the parinirvanna of the previous teacher of the world. ${ }^{658}$ Jayavarman VII, ruler of Ankor, appears to have considered himself a living Buddha, and his two parents prominent Bodhisattvas. ${ }^{659}$ An inscription describes King Khadgodyama of the Samatata region of southeast Bengal (seventh century) as having conquered the earth after declaring his intense devotion to the Three Jewels: the Buddha, his teachings, and the Sangha. ${ }^{660}$

emphasizes morality, though the urge for world conquest is not quite reconciled with non-violence"; Scharfe, 1989: 22, with a reference to Jan, 1984.

${ }^{657}$ Mertens, 2000.

${ }^{658}$ Davidson, 2002: 89; Kielhorn, 1892; Barnett, 1926.

${ }^{659}$ Kulke, forthcoming. About the end of Buddhism after Vijayavarman's death, Kulke states the following: "[The people] was exhausted and impoverished by endless wars with Champa and Jayavarman's megalomania to make them build by forced labour nearly half of the great monuments of Cambodia for his own glorification. Having covered his kingdom with a network of temples, statues of gods and hospitals in a frenzy of missionary zeal, he expressed his compassion for the suffering humanity in the moving language of his inscriptions. But his words could no longer reach a people afflicted by wars and compulsory labour. The people, exhausted by the burden which Jayavarman's buddhist apotheosis placed upon them, turned to Theravada Buddhism which spread from Sri Lanka across Burma to Cambodia since the end of the $12^{\text {th }}$ century."

${ }^{660}$ Sanderson, 2009: 84. 
Once it had become possible for Buddhists to act as counsellors of the king, they could profit from the experience and expertise which the Brahmins had acquired in the course of time. More particularly, they might use the manuals that had been composed by Brahmins, among them the Arthaśāstra and the Laws of Manu. Evidence illustrating this comes from Sri Lanka. We saw in an earlier chapter that the rulers of this island and their buddhist counsellors used these brahmanical texts for running the country.

There is no need to search for further examples. Whether or not the Buddhists succeeded in becoming political counsellors at the royal courts, they could now legitimately aspire to such positions. They could do so because they had come to accept society as a legitimate place to live in, not just as something to flee from.

This new development reduced the gap between Buddhists and Brahmins to a considerable extent. However, the Brahmins had one more trump-card. They did not just offer political counselling. They also offered the magical protection which only they, as possessors of traditional vedic lore, could provide. It seems a fair bet that many rulers appreciated this magical protection as much as they did the political counselling, if not more so. In the realm of magical protection traditional Buddhism had not much to offer. Neither the ascetic practices laid down in the ancient texts nor the rationalized doctrines which Buddhists defended in their Sanskrit debates provided magical protection in any form whatsoever. Certain Buddhists may have come to experience this as a drawback, one which might deprive them of the political support which they yet desperately needed.

It is no doubt in this context that we have to understand the ever stronger tendency to use rites and spells in Buddhism. This tendency was not confined to Buddhism, to be sure, nor was it limited to rites and spells that might be of use to the royal court. ${ }^{661}$ It is yet known, from Tāranātha and other authors, that rituals for state protection were performed on behalf of the monarch at the Vikramaśîla

${ }^{661}$ Some certainly were. Gray (2007: 252) gives an example from the Cakrasamvara Tantra of "a fierce homa rite for the purpose of subduing a rival kingdom". 
monastery and elsewhere. ${ }^{662}$ Sanderson, who draws attention to this, does not hesitate to conclude that "[i]n some sense, ... these were state monasteries, not unlike the great imperial monasteries of Tang China and Japan, rather than autonomous, self-governing institutions."

With regard to the use of rites and spells, it would not be correct to say that there was once a time when Buddhism was completely without them. Protective spells are a common feature of Mahāyāna, and they appear to have been in use already in earlier phases of Buddhism. ${ }^{663}$ It seems yet certain that this use gained enormously in prominence during the centuries now considered.

A relatively early buddhist text that promises protection to the state is the Suvarṇabhāsottama or Suvarnaprabhāsa Sūtra. This text was translated into Chinese between 414 and 421, and must therefore have existed before this date. Geoffrey Samuel (2008: 309-310) says the following about it: ${ }^{664}$

in Chapter 6 of the Suvarnaprabhāsa Sütra, the Four Great Kings, the four $y a k s a$-style deities of the four directions ..., approach the Buddha. They proclaim that should a king of men who has heard this sütra protect and support monks who hold this and the other chief sūtras, they, the four Great Kings, along with their twenty-eight yakșa generals and numerous hundreds of thousands of yaksas, will protect and assist that king and ensure him peace and welfare. Similarly, if he makes gifts to the monks, nuns, laymen and laywomen who hold the chief sūtras, the Four Kings will make his population prosperous. ... They also promise to cause dissension and trouble for any neighbouring king who wants to invade his territory.

Strictly speaking this Sūtra does not offer the protection of mantras. As a matter of fact, philosophically inclined Buddhists held various views about the nature and value of mantras. ${ }^{665}$ It seems yet clear that there was an upsurge of rites and

\footnotetext{
${ }^{662}$ Sanderson, 2009: $105 \mathrm{ff}$.

${ }^{663}$ See however chapter III.1, above. See further Snellgrove, 1987: 121 f.; Davidson, 2002: 144 f.; 2009; Skilling, 1997: 63 f.; 2007a; 2008; Bongard-Levin et al., 1996: 30 f.; Lévi, 1915: 19 ff.; Martin, 2007: 211 f. The gāndhārī vidyā (Pāli gandhārī nāma vijjā) "spell (?) from Gandhāra" is already referred to in the Kevaddha Sutta of the Dīgha Nikāya (I p. 213). Early dhäran̄is are found in the texts from Gilgit; see Hinüber, 1981, and Schopen's (2009: 199) characterization of the rituals in which they were used: "not ... Tantric in any meaningful sense of the term since their performance does not require any initiated officiant, nor is there anything 'esoteric' about their performance."

${ }^{664}$ See Emmerick, 1996: 24 ff.

${ }^{665}$ Braarvig, 1997; Eltschinger, 2001; 2008.
} 
spells from the seventh century CE onward. ${ }^{666}$ It is customary to speak in this connection of tantric Buddhism. The available evidence suggests that tantric Buddhism borrowed extensively from non-buddhist religious currents, most notably Śaivism. ${ }^{667}$

In a recent article, Alexis Sanderson (2005) enumerates a number of factors that contributed to the success of the relevant form of Śaivism. ${ }^{668}$ One of these factors is "that the Śaivism of the Mantramārga developed in practice a thorough accommodation of the brahmanical religion that it claimed to transcend, thus minimizing, even eliminating, the offence it gave as a tradition whose scriptures, like those of the Buddhists, were seen to be, and claimed to be, outside the corpus of the Vedas. These Śaivas were to accept that the brahmanical tradition alone was valid in the domain it claimed for itself and that they were bound to follow its prescriptions and incorporate its rituals beside their own wherever practicable." (p. 231-232). ${ }^{669}$ This process sometimes worked in the opposite direction, as Sanderson points out in an even more recent article (2007). He shows here that Brahmins of the Atharvaveda, in order to respond to the altered expectations of their royal clients, added "Śaiva and Vaiṣnava rituals to their repertoire, composing or appropriating texts that prescribe them and adding these to the corpus of their sacred literature" (Sanderson, 2007: 196). Evidence for this is provided by certain ancillary tracts included in the Atharvavedaparisișța.

Another factor, the most vital one according to Sanderson, "is that the religion succeeded in forging close links with the institution of kingship and thereby with the principal source of patronage." (2005: 232). ${ }^{670}$ It did so in various ways, among them the following. Saiva officiants occupied the office of Royal Preceptor (rājaguru) and in this position they gave Śaiva initiation ( $d \bar{i} k s ̣ \bar{a})$ to the monarch followed by a specially modified version of the Saiva consecration ritual (abhiṣeka) as an empowerment to rule beyond that conferred

\footnotetext{
${ }^{666}$ So Davidson, 2002: $116 \mathrm{f}$.

${ }^{667}$ Sanderson, 1988: 678 f.; 1994; 2009: 128 ff.; but see White, 2005: 8 f.; Ruegg, 2008: 28-29 n. 53; 105 f.; Samuel, 2008: 264 ff.; Davidson, 2009.

${ }^{668}$ The whole issue is taken up again at great length in Sanderson, 2009.

${ }^{669}$ Cp. Sanderson, 2007a: 231 f.; 2009: 249 ff.

${ }^{670}$ See also Gupta \& Gombrich, 1986; Sanderson, 2007a: 241 f.; 288 f.
} 
by the conventional brahmanical royal consecration (rājyäbhișeka). They provided a repertoire of protective, therapeutic and aggressive rites for the benefit of the monarch and his kingdom. They developed Śaiva rituals and their applications to enable a specialized class of Śaiva officiants to encroach on the territory of the Rājapurohita, the brahmanical expert in the rites of the Atharvaveda who served as the personal priest of the king, ${ }^{671}$ warding off all manner of ills from him through apotropaic rites, using sorcery to attack his enemies, fulfilling the manifold duties of regular and occasional worship on his behalf, and performing the funerary and other postmortuary rites when he or other members of the royal family died. ${ }^{672}$

An example of the effectiveness of the protection provided by the Śaivas is provided by the following episode (Sanderson, 2009: 260):

an inscription of the fifth year of the reign of the Cola Rājādhirāja II (r. 1163-1179 or 1166-1182) from the Tiruvālīśvara temple at Ārppākkam near Kāñcīpuram tells us that when an army from Sri Lanka had invaded the Pạndya country, plundered the treasury of the temple of Rāmeśvaram, and interrupted the cult of Śiva there, the emperor, fearing that the war might spread approached a certain Jñānaśivadeva of Gauda, who can be seen from his name to have been a Saiddhāntika Śaiva Guru, to free the country from this menace by ritual means. The Guru, we are told, then worshipped Śiva for this purpose for twenty-eight days continuously, and it was reported subsequently that these 'attackers of Śiva' (sivadroh $\vec{\imath}$ ) had indeed been defeated.

The Śaivas were not however the only ones to attempt to forge links with royalty in this manner. Buddhists tried to do so, too. Sanderson (2005: 238) gives some examples: ${ }^{673}$

We see similar cases of regularization of rites of royal protection in our evidence for the buddhist Way of Mantras. The Rgya gar chos 'byun, the Tibetan history of Indian Buddhism completed by Tāranātha in AD 1608, reports that in order to protect his dynasty, expand its rule, and spread the buddhist religion the Pāla king Dharmapāla (r. c. 775-812) had a fire-

\footnotetext{
${ }^{671}$ On the precise qualifications of Purohitas and their historical development, see Inden, 1992; further Willis, 2009: 169-182.

${ }^{672}$ Sanderson, 2005: 233, $238 \mathrm{f}$.

${ }^{673}$ See further Sanderson, 2009: $124 \mathrm{ff}$.
} 
sacrifice performed regularly for many years by Tantric officiants under the direction of his Guru Buddhajñānapāda at an overall cost of 902,000 tolas of silver.

An inscription of the reign of Jayavarman V (r. c. 968 - c. 1000/1) reveals a similar arrangement in the Khmer court of Angkor. It tells us that one Kīrtipaṇịta, a Mahāyānist scholar and adept of the buddhist Yogatantras, who had been adopted by the royal family as their Guru, was frequently engaged by the king to perform apotropaic, restorative and aggressive Mantra rituals within the royal palace for the protection of his kingdom.

The Kīrtipaṇ̣ita here mentioned is, of course, the same Kīrtipaṇitita whom we met earlier. This buddhist minister was apparently appreciated at the Khmer court for his ability to perform "apotropaic, restorative and aggressive Mantra rituals". ${ }^{674}$ There is not much direct evidence from South and Southeast Asia to show that the new emphasis on incantations and rites had as one of its aims to secure a place for Buddhists at the royal court, apart from the cases just considered. Mention can here be made of the description of a war machine in an Indian buddhist tantric text, the Kālacakra Tantra. ${ }^{675}$ This unexpected description in a tantric text may find a partial explanation in the fact that this text foresees a final and definitive battle between Buddhism and Islam, in which the latter will be destroyed. ${ }^{676}$ It yet shows the proximity that was felt to exist between Buddhism and the political powers that were to make use of this war machine.

We had occasion to speak about the brahmanical hermit Bharadvāja, who, according to the Rāmāyaṇa, received and entertained Rāma's brother Bharata along with his army in a manner that the king could not equal. tantric Buddhism, too, came to have its powerful ascetics, often called siddhas "accomplished ones". This topic cannot be explored here, but one story from Abhayadatta's Caturaśîtisiddhapravrtti may be presented by way of illustration: ${ }^{677}$

In the city of Kansati, Virūpa bought wine from a tavern girl; she gave him a glass of wine and a plate of rice which he greatly enjoyed. He continued

\footnotetext{
${ }^{674}$ On the expression of violence in buddhist tantric mantras, see Verhagen, 1999.

${ }^{675}$ Grönbold, 1996.

${ }^{676}$ For references to Islam in the Kālacakra Tantra, see Ruegg, 2008: 116-17 (with references to further secondary literature).

${ }^{677}$ Samuel, 1993: 431, citing from Robinson, 1979: 29.
} 
eating and drinking. For the space of two days and a night, he prevented the sun from moving and the king, amazed, exclaimed: "Who is it who performs such a miracle?" In answer, the goddess of the sun appeared to the king in a dream and said, "A yogin has pledged me as payment to a tavern girl." The king and his subjects paid the price of the wine, which came to a million glasses, and Virūpa disappeared.

Geoffrey Samuel (1993: 431), who cites this story, comments: "What is ... notable about this story is the implicit comparison of Virupa's tantric power and the king's temporal power." Indeed, and as in the case of the story of Bharadvāja, it is clear that the king's power cannot compare with that of the ascetic. In other words, tantric Buddhism, like Brahmanism before it, claimed great powers which the king would be wise to respect and honour.

If the evidence from South Asia concerning the political role that buddhist rites and spells were meant to play is limited, it is known that Buddhism owed much of its attraction in China, Japan and elsewhere to its supposed capacity to defend the state against danger. ${ }^{678}$ It may be true, as Ronald Davidson (2005: 23 f.) points out, that "Indian esoteric Buddhism did not arise for the express purpose of converting the courts and appealing to the intelligentsia of Tibet, China, Japan, Burma, or elsewhere", it is equally true that "its success was ... dramatic in these areas". The tantric master Amoghavajra, to take an example, helped to defeat the invasion of China in 742 CE by a combined force of Tibetans, Arabs, Sogdians and others. He did this through certain rituals derived from a buddhist text specifically concerned with the protection of the state. ${ }^{679}$ Buddhist monks in China were exempted from military service, but were expected to execute tantric buddhist rites that would provide protection against natural and other disasters, most in particular war and enemies. ${ }^{680}$ In Japan, in 940 CE, the state was threatened by a rebellion. The Shingon priest Kanjo was directed by the Emperor to bring an image of Fūdō, a tantric deity, to Narita in order to defeat the rebellion. After three weeks of continual fire offerings, the leader of the rebellion,

\footnotetext{
${ }^{678}$ Cf. Samuel, 2008: $309 \mathrm{ff}$.

${ }^{679}$ Samuel, 2002: 10 (104 f.), with a reference to Chandra, 1992. For the activities of tantric Buddhists at and around the imperial court, see Strickmann, 1996: $213 \mathrm{f}$.

${ }^{680}$ Demiéville, 1957: 355. See also Shen, 2004.
} 
Taira no Masakado, was killed by the Emperor's forces and peace was restored. At least some of the credit was given to the Fūdō rituals. ${ }^{681}$ Jörg Plassen points out that the monk Hye-gwan, in the early $7^{\text {th }}$ century, ascended to the rank of monastic overseer (Sōjō) in Japan, arguably less so because of his knowledge of San-lun thought, but due to his success in rain-making. ${ }^{682}$ Geoffrey Samuel (2002) presents an interesting argument to show that one of the reasons why Tibet adopted Buddhism in the eighth century was the same or similar to the one that attracted the Chinese and the Japanese, viz., to secure the state and the position of the king. ${ }^{683}$ Also later, rituals were used in Tibet to secure the subjugation or annihilation of enemies. ${ }^{684}$ It follows from these and other examples that there are plenty of reasons to think that the tantric turn of Buddhism opened up a niche which had so far been inaccessible to this religion, and which the Buddhists had been accustomed to leave to the Brahmins.

There is another feature of tantric Buddhism that might be taken as evidence for the political role that its rites and spells were meant to play. Tantric buddhist ritual, as Ronald Davidson points out, is full of political metaphors. This imperial metaphor, as Davidson calls it, finds expression in the explicit relationship between the initiatory ritual of the abhiseka and the coronation ritual of kingship (2002: $123 \mathrm{f}$.). The manḍalas which serve as objects of meditation, moreover, "are implicitly and explicitly articulations of a political horizon in which the central Buddha acts as the Rājādhirāja [Supreme Overlord, JB] in relationship to the other figures of the mandala" (p. 131). Moreover, "Buddhists derived their mandala forms and functions ... from their immediate observation at the disposition and execution of realpolitik in their environment" (p. 139). These and other examples show that esoteric Buddhism internalized the political models

\footnotetext{
${ }^{681}$ Samuel, 2002: 11 (106).

${ }^{682}$ In a lecture ("Nativist tendencies in the history of Korean buddhist thought") held during a symposium ("“Nativism' in buddhist environments") held at the EKO-Haus der Japanischen Kultur (Düsseldorf) in September 2008.

${ }^{683}$ See also Walter, 2009: 195: "the perhaps surprising conclusion ... is that Sanghas could have performed any sort of rite the courts felt were needed."

${ }^{684}$ Schmithausen, 1996: $80 \mathrm{f}$. On Buddhism and the state in early Tibet in general, see Walter, 2009. On the not altogether idyllic nature of traditional Tibetan society, see Parenti, 2007; Trimondi, 1999: 478 f. Western notions of Tibet are exposed in Lopez, 1998.
} 
of medieval India (p. 160). Davidson suggests that, in this way, "the great litterateurs and teachers of North Indian monasteries [were] trying to sanctify the world as they received and accepted it". The mission of buddhist cloisters, he adds, "was a consensual effort at sanctifying society" (p. 161). This, if true, is of course of the greatest interest in our present context. Buddhism had always abstained from justifying society in any of its forms, not to speak of sanctifying it. Davidson's analysis suggests that the buddhist attitude to society had changed most radically.

Does this mean that Buddhism had now succeeded in freeing itself from the weight of Brahmanism? For many centuries, though not right from the beginning, subcontinental Buddhism had conceded to a form of cohabitation with Brahmanism in which the latter was responsible for matters of state, society, and much else. It took Buddhists many centuries to emancipate themselves from this tutelage. Had they finally succeeded now that they admitted that Buddhists, too, could play roles in society, including the role of ruler or counsellor to the ruler? and that they could compete with Brahmins even in the domain of rites and incantations? To some extent, the answer is no doubt yes. Buddhists could now develop ideas about the way the state should be run, and they could now offer the kind of supernatural protection that had always been provided by Brahmins. ${ }^{685}$ However, the Buddhists remained indebted to Brahmanism in various ways. This can be seen as follows.

The Buddhists of South Asia had not developed any realistic ideas about statecraft of their own. They had slowly come to accept many of the brahmanical ideas. They themselves never produced more than modified versions of these brahmanical ideas. The buddhist concept of the ruler as a Bodhisattva was new, to be sure, as was the accompanying view that rulers acted for the soteriological

\footnotetext{
${ }^{685}$ One would think that they might even occupy themselves with astrology and related sciences. It is in this connection interesting to note that Amoghavajra, the tantric buddhist master in China whom we met before, is also reported to have been the author of a text on Indian astrology (Yano, 1987). Outside the subcontinent, Buddhists no longer shied away from astrology, divination and mathematics; see Brian Baumann's book Divine Knowledge: Buddhist Mathematics According to the Anonymous Manual of Mongolian Astrology and Divination (Leiden 2008; reviewed by Vesna A. Wallace (2010)).
} 
well-being of their subjects. In practical terms, however, I know of no evidence that might show that Buddhists in South and Southeast Asia really struck out on their own. The brahmanical model was and remained the basis of their political thought.

In the realm of supernatural protection by means of rites and spells one might expect a greater distance from the brahmanical tradition. Buddhists underwent in this area the influence of Śaivism, which was itself in competition with traditional Brahmanism. In spite of this, tantric Buddhism contains many features that were directly taken from the orthodox brahmanical tradition. A recent study by Shrikant Bahulkar (forthcoming) shows that vedic concepts, practices, and even Rgvedic mantras found a place in this form of Buddhism. Its texts do not even hesitate to mention the brahmanical division of society into four caste-classes (varna), whose existence they clearly take for granted. As an example of this last feature we may consider three parallel Buddhists texts dealing with a rite called the Ahorātravrata, texts which have recently been edited by Ratna Handurukande (2000). All three of these texts contain detailed stipulations as to the ways Brahmins, Kṣatriyas, Vaiśyas, Śūdras and those belonging to lower castes should perform their worship. The lowest castes are discouraged from worshipping at all, or at the very least they are told to stay far away from the object of veneration. ${ }^{686}$

South Asian Buddhists, then, have had little opportunity to reassert themselves against the Brahmins who had been their rivals for so long. Their ultimately unsuccessful attempts at doing so took them far from the ideas and practices they had adhered to during the early centuries of their religion, and dangerously close to their much-detested rivals.

Are we to conclude from the preceding reflections that Buddhism was doomed from the beginning in the Indian subcontinent? Such a conclusion would of course go well beyond what we can legitimately infer from the historical evidence. It is yet remarkable that Buddhism, in order to survive for as long as it did in South Asia, had to undergo rather drastic adjustments. Our investigations

${ }^{686}$ Handurukande, 2000: xvii, 22 f., 75 f., 88, 107 f., 120, 125. 
suggest that either it had to modify itself in such a way as to be able to provide ideological and practical support to the agents of political power; alternatively, it had to conclude a pact with a tradition that could provide such support. Buddhism in South Asia, as we have seen, initially chose for the second solution. From an early date onward it was willing to work in tandem with Brahmanism, adopting at least part of the latter's social and political ideology, or perhaps more precisely: leaving the care of society and the state to the Brahmins. This did not save Buddhism, as we now know. The subsequent changes that found expression in the massive adoption of rites and spells did not save Buddhism in South Asia either. It is yet interesting to observe that most if not all forms of Buddhism that have survived until today fall in either of these two categories. The Buddhism which we find in much of Southeast Asia has maintained its association with Brahmanism, admittedly in a strongly reduced and weakened form; in Sri Lanka this is true to the extent that there are no Brahmins left on the island. In most other regions that have adopted Buddhism, it is its tantric form that has been selected. This allows me to conclude with the following words which I borrow from David Gordon White (2005: 3), "while the esoteric turn did not save the sinking ship of Buddhism in India, it made it highly attractive as an export commodity". 


\section{References:}

$\bar{A}$ di Purāna of Jinasena. Part II. Edited, with Hindi translation, introduction and appendices, by Dr. Pannalal Jain. New Delhi: Bharatiya Jnanpith. Tenth edition, 2005.

Agostini, Giulio (2008): "Partial upāsakas." Buddhist Studies. Ed. Richard Gombrich \& Cristina Scherrer-Schaub. Delhi: Motilal Banarsidass. (Papers of the $12^{\text {th }}$ World Sanskrit Conference, 8.) Pp. 1-34.

Aklujkar, Ashok (2003): "A different sociolinguistics for Brahmins, Buddhists and Jains." Contemporary Views on Indian Civilization. Ed. Bhu Dev Sharma. Meerut: World Association for Vedic Studies. Pp. 54-69.

Ali, Daud (2004): Courtly Culture and Political Life in Early Medieval India. Cambridge University Press.

Allon, Mark \& Salomon, Richard (2000): "Kharoșthī fragments of a Gāndhārī version of the Mahāparinirvāna-sūtra." Buddhist Manuscripts, I. (Manuscripts in the Schøyen Collection, I.) Ed. Jens Braarvig. Oslo: Hermes Publishing. Pp. 243-273.

Andersen, Paul Kent (1990): Studies in the Minor Rock Edicts of Aśoka, I: Critical edition. Freiburg: Hedwig Falk.

Angot, Michel (2008): Le Yoga-Sūtra de Patañjali, le Yoga-Bhāṣya de Vyāsa, avec des extraits du Yoga-Vārttika de Vijñāna-Bhikșu. Édition, traduction et présentation. Paris: Les Belles Lettres.

Angot, Michel (2009): Le Nyāya-Sūtra de Gautama Akṣapāda-Le Nyāya-Bhāsya d'Akșapāda Pakșilasvāmin: L'art de conduire la pensée en Inde ancienne. Édition, traduction et présentation. Paris: Les Belles Lettres.

Annambhațta: Uddyotana I. In: Mahābhāṣya Pradīpa Vyākhyānāni I (Adhyāya 1 Pāda 1 Āhnika 1-4). Édition par M.S. Narasimhacharya, présentation par Pierre-Sylvain Filliozat. Pondichéry: Institut Français d'Indologie. 1973.

Arthaśāstra. See Kangle, 1969.

Arundhati, P. (1990): Brāhmanism, Jainism and Buddhism in Āndhra D, śa. Delhi: Sundeep Prakashan.

Assmann, Jan (2003): Die Mosaische Unterscheidung oder der Preis des Monotheismus. München - Wien: Carl Hanser.

Aśvaghoṣa: Buddhacarita. See Johnston, 1936.

Bahulkar, Shrikant (forthcoming): "Veda and Vedism in Buddhist Tantric literature."

Bakker, Hans T. (2007): "Monuments to the dead in ancient North India." IIJ $50(1), 11-47$.

Balbir, Nalini (2009): "Les lecteurs jaina śvetāmbara face à leur canon.” Écrire et transmettre en Inde classique. Ed. Gérard Colas \& Gerdi Gerschheimer. Paris: École française d'Extrême-Orient. (Études thématiques, 23.) Pp. 4362.

Bapat, P.V. (1928): "A comparative study of a few Jain Ardhamāgadhi texts with the texts of the Buddhist Pāli Canon." Sir Asutosh Memorial Volume.

Patna: J. N. Samaddar. Part II. Pp. 91-105.

Bareau, André (1962): "La légende de la jeunesse du Buddha dans les Vinayapițaka anciens." Oriens Extremus (Zeitschrift für Sprache, Kunst un Kultur der Länder des Fernen Ostens) 9, 6-33. 
Bareau, André (1962a): "La construction et le culte des stūpa d'après les Vinayapitaka.” BEFEO 50(2), 229-274.

Bareau, André (1963): Recherches sur la biographie du Buddha dans les Sūtrapitaka et les Vinayapitaka anciens: de la quête de l'éveil à la conversion de Śāriputra et de Maudgalyāyana. Paris: École Française d'Extrême-Orient. (Publications de l'École Française d'Extrême-Orient, 53.)

Bareau, André (1970-1971): Recherches sur la biographie du Buddha dans les Sütrapitaka et les Vinayapițaka anciens: II: les derniers mois, le parinirvāna et les funérailles. 2 vols. Paris: École Française d'ExtrêmeOrient. (Publications de l'École Française d'Extrême-Orient, 77.)

Bareau, André (1975): "Les récits canoniques des funérailles du Buddha et leurs anomalies: nouvel essai d'interprétation." BEFEO 62, 151-189.

Bareau, André (1993): "Le bouddha et les rois." BEFEO 80(1), 15-39.

Barnett, Lionel D. (1926): “The Mungir plate of Devapāladeva: samvat 33." EpInd 18 (1925-26), 304-307.

Barthes, Jean (1952): "Les reliques sacrées à Phnom-Penh (5-11 octobre 1952)." France-Asie 8, no. 78: 951-956.

Barua, Dipak Kumar (1969): Vihāras in Ancient India. A survey of Buddhist monasteries. Calcutta: Indian Publications.

Bayly, Susan (1999): Caste, Society and Politics in India frm the Eighteenth Century to the Modern Age. Cambridge University Press. (The New Cambridge History of India IV.3.)

Bechert, Heinz (1966): Buddhismus, Staat und Gesellschaft in den Ländern des Theravāda-Buddhismus. Erster Band: Allgemeines und Ceylon. Frankfurt am Main - Berlin: Alfred Metzner. (Schriften des Instituts für Asienkunde in Hamburg, XVII/1.)

Bechert, Heinz (1986): Die Lebenszeit des Buddha — das älteste feststehende Datum der indischen Geschichte? Göttinge: Vandenhoeck \& Ruprecht. (Nachrichten der Akademie der Wissenschaften in Göttingen, I. Philologisch-historische Klasse, Jahrgang 1986, Nr. 4, pp. 127-184.)

Bechert, Heinz (ed.)(1991, 1992, 1997): The Dating of the Historical Buddha / Die Datierung des historischen Buddha. Parts 1-3. (Symposien zur Buddhismusforschung, IV, 1-3.) Göttingen: Vandenhoeck \& Ruprecht. (Abhandlungen der Akademie der Wissenschaften in Göttingen, philologisch-historische Klasse, Dritte Folge, Nr. 189, 194, 222.)

Bechert, Heinz (ed.)(1995): When Did the Buddha Live? The Controversy on the Dating of the Historical Buddha. Selected papers based on a symposium held under the auspices of the Academy of Sciences in Göttingen. Delhi: Sri Satguru Publications. (Bibliotheca Indo-Buddhica Series, 165.)

Bechert, Heinz (2005): Eine regionale hochsprachliche Tradition in Südasien: Sanskrit-Literatur bei den buddhistischen Singhalesen. Wien: ÖAW. (Veröffentlichungen zu den Sprachen und Kulturen Südasiens, Heft 37; Sitzungsberichte / ÖAW, Philosophisch-historische Klasse, 718. Band.)

Bechert, Heinz \& al. (2000): Der Buddhismus I. Der indische Buddhismus und seine Verzweigungen. Stuttgart: W. Kohlhammer. 2000. (Die Religionen der Menschheit, vol. 24,1.)

Bechert, Heinz \& Braun, Heinz (1981): Pāli Nīti Texts of Burma: Dhammanīti, 
Lokanīti, Mahārahanìti, Rājanīti. London, Henley and Boston: Routledge

\& Kegan Paul. (Pali Text Society, Text Series no. 171.)

Beck, Hermann (1916): Buddha und seine Lehre. Reprint: Verlag Freies Geistesleben Stuttgart, 1958.

Behrendt, Kurt A. (2004): The Buddhist Architecture of Gandhāra. Leiden Boston: Brill. (Handbook of Oriental Studies, section two: India, 17.)

Bénisti, Mireille (1960): "Étude sur le stūpa dans l'Inde ancienne.” BEFEO 50(1), 37-116 + XXX planches.

Benveniste, Émile (1958): “Les données iraniennes." JA 246, 36-48. (Cette contribution fait partie d'un article plus long, "Une billingue grécoaraméenne d'Asoka", qui contient encore des contributions par Daniel Schlumberger, Louis Robert, et André Dupont-Sommer, et qui couvre les pages 1-48 du dit tome du Journal Asiatique.)

Bhandare, Shailendra (2006): "Numismatics and history: the Maurya-Gupta interlude in the Gangetic plain." = Olivelle, 2006: 67-112.

Bhandarkar, D. R. (1938): "Silaharā cave inscriptions.” EpInd 32 (1933-34), 3036.

Bharț̣hari: Vākyapadīya. 1) Edited by Wilhelm Rau. Wiesbaden: Franz Steiner. 1977. (Abhandlungen für die Kunde des Morgenlandes, XLII, 4.) 2) Kāṇda I edited, with the Vrtti and the Paddhati of Vrsabhadeva, by K. A. Subramania Iyer. Poona: Deccan College. 1966. (Deccan College Monograph Series, 32.) 3) Kānḍa III part 1 edited, with the commentary of Helārāja, by K. A. Subramania Iyer. Poona: Deccan College. 1963. (Deccan College Monograph Series, 21.)

Bhartṛhari: Mahābhāṣyadīpikā. Fasc. IV: Āhnika I. Edited by Johannes Bronkhorst. Poona: Bhandarkar Oriental Research Institute. 1987. (PostGraduate and Research Department Series, 28.)

Bhattacharya, Kamaleswar (1997): "Religious syncretism in ancient Cambodia." Dharmadūta. Mélanges offerts au Vénérable Thich Huyên-Vi à l'occasion de son soixante-dixième anniversaire. Ed. Bh. T. Dhammaratana, Bh. Pāsādika. Paris. Pp. 1-12. (not seen)

Bhattacharya, Kamaleswar (2006): "Unity in diversity: anattā revisited." Sanskrit Studies Centre Journal (Silpakorn University, Bangkok) 2, 1-7.

Biardeau, Madeleine (1964): Théorie de la connaissance et philosophie de la parole dans le brahmanisme classique. Paris - La Haye: Mouton.

Biardeau, Madeleine (2002): Le Mahābhārata. Un récit fondateur du brahmanisme et son interprétation. Tome I. Paris: Éditions du Seuil.

Black, Brian (2007): The Character of the Self in Ancient India. Priests, kings, and women in the early Upanisads. Albany: State University of New York Press.

Bloch, Jules (1950): Les inscriptions d'Asoka. Traduites et commentées. Paris: Les Belles Lettres.

Bloomfield, Maurice (1899): The Atharva Veda. Strassburg: Karl J. Trübner. Reprint (under the title The Atharvaveda and the Gopath Brahmana): Asian Publication Services, New Delhi, 1978.

Bodewitz, H. W. (1990): The Jyotiṣtoma Ritual. Jaiminīya Brāhmaṇa I, 66-364. Introduction, translation and commentary. Leiden etc.: E. J. Brill. (Orientalia Rheno-Traiectina, 34.) 
Bodewitz, H. W. (2002): "The dark and deep underworld in the Veda." JAOS 122(2), 213-223.

Boesche, Roger (2002): The First Great Political Realist. Kautilya and his Arthashastra. Lanham etc.: Lexington Books.

Bollée, Willem B. (1998): Bhadrabāhu Bṛhat-Kalpa-Niryukti and Sanghadāsa Brhat-Kalpa-Bhāsya. Romanized and metrically revised version, notes from related texts and a selective glossary. Part one: Pìthika and Uddeśa 1. Stuttgart: Franz Steiner. (Beiträge zur Südasienforschung, SüdasienInstitut, Universität Heidelberg, Band 181,1.)

Bongard-Levin, Gregory M. (2001): "Brahman Cānakya in the Graeco-Roman tradition." Le Parole e i Marmi. Studi in onore di Raniero Gnoli nel suo $70^{\circ}$ compleanno. Ed. Raffaele Torella. Roma: Istituto Italiano per 1'Africa e 1'Oriente. (Serie Orientale Roma XCII,1.) Pp. 111-122.

Bongard-Levin, Gregory; Boucher, Daniel; Fukita, Takamichi \& Wille, Klaus (1996): "The Nagaropamasūtra: An apotropaic text from the Samyuktāgama. A Transliteration, Reconstruction, and Translation of the Central Asian Sanskrit Manuscripts." Sanskrit-Texte aus dem buddhistischen Kanon: Neuentdeckungen und Neueditionen III. (SanskritWörterbuch der buddhistischen Texte aus den Turfan-Funden, Beiheft 6.) Göttingen: Vandenhoeck \& Ruprecht. Pp. 7-131.

Borst, Arno (1957-1963): Der Turmbau von Babel. Geschichte der Meinungen über Ursprung und Vielfalt der Sprachen und Völker. 6 vols. Stuttgart: Anton Hiersemann.

Boucher, Daniel (2008): Bodhisattvas of the Forest and the Formation of the Mahāyāna. A study and translation of the Rāsțrapālapariprcchā-sūtra. Honolulu: University of Hawai'i Press.

Bouillier, Véronique (1979): Naître renonçant. Une caste de sannyāsi villageois au Népal central. Nanterre: Laboratoire d'Ethnologie. (Recherches sur la Haute Asie, 5.)

Bouillier, Véronique (1997): Ascètes et rois: Un monastère de Kanphata Yogis au Népal. Paris: CNRS.

Bouillier, Véronique (2004): Itinérance et vie monastique: Les ascètes Nāth Yogīs en Inde contemporaine. Paris: Fondation de la Maison des sciences de l'homme.

Bouillier, Véronique (2008): "Grottes et tombes: les affinités des Nāth Yogīs avec le monde souterrain." Rivista di Studi Sudasiatici 3, 33-48.

Braarvig, Jens (1997): "Bhavya on mantras: apologetic endeavours on behalf of the Mahāyāna." Studia Indologiczne 4, 31-39.

Bretfeld, Sven (2001): Das Singhalesische Nationalepos von König Duțthagāman̄̄ Abhaya. Textkritische Bearbeitung und Übersetzung der Kapitel VII.3VIII.4 der Rasavāhinī des Vedeha Thera und Vergleich mit den Paralleltexten Sahassavatthuppakaraṇa und Saddharmālañkāraya. Berlin: Dietrich Reimer. (Monographien zur Indischen Archäologie, Kunst und Philosophie, 13.)

Briggs, George Weston (1938): Gorakhnāth and the Kānphața Yogīs. Reprint: Motilal Banarsidass, Delhi etc., 1982.

Brinkhaus, Horst (1978): Die altindischen Mischkastensysteme. Wiesbaden: Franz Steiner. (Alt- und Neu-Indische Studien, 19.) 
Bronkhorst, Johannes (1985): "On the chronology of the Tattvārtha Sūtra and some early commentaries." WZKS 29, 155-184.

Bronkhorst, Johannes (1988): "Études sur Bhartrhhari, 1: L'auteur et la date de la Vṛtti." BEI 6, 105-143.

Bronkhorst, Johannes (1991): "Two literary conventions of classical India." AS 45(2), 210-227.

Bronkhorst, Johannes (1992): "Quelques axiomes du Vaiśeșika." Les Cahiers de Philosophie 14 ("L’orient de la pensée: philosophies en Inde"), 95-110.

Bronkhorst, Johannes (1993a): The Two Traditions of Meditation in Ancient India. Delhi: Motilal Banarsidass.

Bronkhorst, Johannes (1999): Langage et réalité: sur un épisode de la pensée indienne. Turnhout: Brepols. (Bibliothèque de l'École des Hautes Études, Sciences Religieuses, 105.) (An English translation will soon be brought out by Brill, Leiden)

Bronkhorst, Johannes (2000): "Abhidharma and Jainism." Abhidharma and Indian Thought. Essays in honor of Professor Doctor Junsho Kato on his sixtieth birthday. Ed. Committee for the Felicitation of Professor Doctor Junsho Kato's Sixtieth Birthday, Nagoya. Tokyo: Shuju-sha. Pp. 598-581 ([13]-[30]).

Bronkhorst, Johannes (2002): "Patañjali and the Buddhists." Buddhist and Indian Studies in Honour of Professor Sodo Mori. Hamamatsu: Kokusai Bukkyoto Kyokai (International Buddhist Association). Pp. 485-491.

Bronkhorst, Johannes (2003): "Jainism's first heretic and the origin of anekāntavāda." Jainism and Early Buddhism: Essays in Honor of Padmanabh S. Jaini. Ed. Olle Qvarnström. Fremont, California: Asian Humanities Press. Pp. 95-111.

Bronkhorst, Johannes (2004): From Pānini to Patañjali: the search for linearity. Pune: Bhandarkar Oriental Research Institute. (Post-graduate and Research Department Series, 46.)

Bronkhorst, Johannes (2005): “Les reliques dans les religions de l'Inde.” Indische Kultur im Kontext. Rituale, Texte und Ideen aus Indien und der Welt. Festschrift für Klaus Mylius. Hrsg. Lars Göhler. Wiesbaden: Harrassowitz. 2005. (Beiträge zur Indologie, 40.) Pp. 49-85.

Bronkhorst, Johannes (2006): "The context of Indian philosophy." Conflict between Tradition and Creativity in Indian Philosophy: Text and Context. Proceedings of the Seventh International Conference, Studies for the Integrated Text Science. Ed. Toshihiro Wada. Nagoya: Graduate School of Letters, Nagoya University. (21st Century COE Program, International Conference Series No. 7.) Pp. 9-22.

Bronkhorst, Johannes (2006a): "Systematic philosophy between the empires: some determining features." = Olivelle, 2006: 287-313.

Bronkhorst, Johannes (2007): Greater Magadha. Studies in the culture of early India. Leiden - Boston: Brill. (Handbook of Oriental Studies, 2/19.)

Bronkhorst, Johannes (2007a): "Modes of debate and refutation of adversaries in classical and medieval India: a preliminary investigation." Antiqvorum Philosophia 1 ("Forme di dibattito e di confutazione degli avversari nel pensiero antico"), 269-280. 
Bronkhorst, Johannes (2009): Buddhist Teaching in India. Boston: Wisdom Publications.

Bronkhorst, Johannes (2009a): Absorption: Two Studies of Human Nature. http://www.bronkhorst-absorption.info/

Bronkhorst, Johannes (2010): "Ritual, holophrastic utterances, and the symbolic mind." Ritual Dynamics and the Science of Ritual. Volume I: Grammar and morphologies of ritual practices in Asia. Ed. Axel Michaels and Anand Mishra. Wiesbaden: Harrassowitz. Pp. 165-207. (Reprint: Bronkhorst, 2009a: 1-39.)

Bronkhorst, Johannes (forthcoming): "Manu and the Mahābhārata." Festschrift Elizarenkova. Ed. Leonid Kulikov.

Bronkhorst, Johannes (forthcoming a): "Rites without symbols."

Brough, John (1954): "The language of the Buddhist Sanskrit texts." BSOAS 16, 351-375. Reprint: Brough, 1996: 130-154.

Brough, John (1996): Collected Papers. Ed. Minoru Hara and J. C. Wright. London: School of Oriental and African Studies.

Brucker, Egon (1980): Die spätvedische Kulturepoche nach den Quellen der Śrauta-, Gṛhya-, und Dharmasūtras : Der Siedlungsraum. Wiesbaden: Franz Steiner. (Alt- und Neu-Indische Studien, 22.)

Burgess, Jas. (1881): Report on the Buddhist Cave Temples and their Inscriptions. Reprint: Bhartiya Publishing House, Varanasi, 1975.

Burgess, Jas. (1883): Report on the Elura Cave Temples and the Brahmanical and Jaina Caves in Western India. Reprint: Indological Book House, Varanasi, 1970.

Burnouf, E. (1876): Introduction à l'histoire du bouddhisme indien. Deuxième édition, rigoureusement conforme à l'édition originale [de 1844], et précédé d'une notice de Barthélemy Saint-Hilaire. Paris: Maisonneuve.

Burrow, John (2007): A History of Histories. Epics, chronicles, romances and inquiries from Herodotus and Thucydides to the twentieth century. London etc.: Allen Lane.

Burrow, T. (1956): Review of Mukhopadhyaya, 1954. JRAS, 1956, pp. 254-255.

Bussagli, Mario (1984/1996): L'art du Gandhāra. Traduit de l'italien par Béatrice Arnal. La Pochothèque.

Caland, W. (1896): Die Altindischen Todten- und Bestattungsgebräuche, mit Benutzung handschriftlicher Quellen dargestellt. Amsterdam: Johannes Müller. (Verhandelingen der Koninglijke Akademie van Wetenschappen te Amsterdam, Afdeeling Letterkunde, Deel I, no. 6.)

Caland, W. (1908): Altindische Zauberei. Darstellung der altindischen 'Wunschopfer'. Amsterdam: Johannes Müller. (Verhandelingen der Koninklijke Akademie van Wetenschappen te Amsterdam, Afdeeling Letterkunde, Nieuwe reeks, deel X. No. 1.)

Caland, W. (ed.)(1941): Vaikhānasa-Śrautasūtram. The description of Vedic rites according to the Vaikhānasa school belonging to the Black Yajurveda. Calcutta: Baptist Mission Press / Royal Asiatic Society of Bengal.

Candrakīrti: Prasannapadā. Madhyamakaśāstra of Nāgārjuna with the commentary Prasannapadā by Candrakīrti. Edited by P. L. Vaidya. Second edition by Shridhar Tripathi. Darbhanga: Mithila Institute. 1987. (Buddhist Sanskrit Texts, 10.) 
Caraka-saṃhitā of Agniveśa. Edited, with Cakrapāṇidatta's Āyurveda-Dīpikā, by Vaidya Jādavaji Trikamji Āchārya. Fourth edition. New Delhi: Munshiram Manoharlal. 1981.

Cardona, George (1976): Pānini. A survey of research. The Hague: Mouton. Réimpression : Motilal Banarsidass, Delhi, 1980.

Cardona, George \& Jain, Dhanesh (2003): "General introduction." In: The IndoAryan Languages. Ed. George Cardona and Dhanesh Jain. London and New York: Routledge. Pp. 1-45.

Chakrabarti, Dilip K. (1997): The Archaeology of Ancient Indian Cities. Delhi: Oxford University Press.

Chakraborti, Haripada (1974): Early Brāhmī Records in India (c. 300 B.C. -c. 300 A.D.). An analytical study: social, economic, religious, and administrative. Calcutta: Sanskrit Pustak Bhandar.

Chakraborti, Haripada (1978): India as Reflected in the Inscriptions of the Gupta Period. New Delhi: Munshiram Manoharlal.

Chakravarti, Uma (1987): The Social Dimensions of Early Buddhism. Delhi: Oxford University Press.

Chakravarti, Uma (2006): Everyday Lives, Everyday Histories: Beyond the Kings and Brahmanas of 'Ancient' India. New Delhi: Tulika Books.

Champakalakshmi, R. (1996): Trade, Ideology and Urbanization. South India 300 $B C$ to $A D$ 1300. Delhi etc.: Oxford University Press.

Chanchreek, K. L. \& Jain, Mahesh K. (2005): "Jainism in Mathura." Encyclopedia of Jain Religion, volume 11. New Delhi: Shree Publishers \& Distributors.

Chandra, Lokesh (1992): "Tantras and the defence of T'ang China." Cultural Horizons of India, vol. 2. (Śata-Pitaka Series, 366.) Pp. 257-266.

Charvet, Pascal (tr.)(2002): Arrien : Le Voyage en Inde d'Alexandre le Grand. Commentaires de Pascal Charvet, Fabrizia Baldissera et Klaus Karttunen. Paris: NiL.

Chatterjee, Mitali (1999): Education in Ancient India (from literary sources of the Gupta age). New Delhi: D. K. Printworld. (Reconstructing Indian History \& Culture, 17.)

Chatterji, Bijan Raj (1928): Indian Cultural Influence in Cambodia. Calcutta: University of Calcutta.

Chauhan, Gian Chand (2004): Origin and Growth of Feudalism in Early India: From the Mauryas to AD 650. New Delhi: Munshiram Manoharlal.

Chen, Jinhua (2002): "Śarīra and scepter : empress Wu's political use of Buddhist relics." JIABS 25(1-2), 33-150.

Ch'en, Kenneth K. S. (1964): Buddhism in China. A historical survey. Princeton, New Jersey: Princeton University Press.

Ch'en, Kenneth K. S. (1973): The Chinese Transformation of Buddhism. Princeton: Princeton University Press.

Chhabra, B. Ch. (1935): "Expansion of Indo-Aryan culture during Pallava rule, as evidenced by inscriptions." Journal of the Asiatic Society of Bengal (Letters) 1(1), 1-64.

Choong, Mun-keat (forthcoming): “A comparison of the Pāli and Chinese versions of the Brāhmana Samyutta, a collection of early Buddhist discourses on the priestly Brāhmanas." BSOAS 
Clark, Matthew (2006): The Daśanāmì-Samnyā̄sīs. The integration of ascetic lineages into an order. Leiden - Boston: Brill. (Brill's Indological Library, 25.)

Clémentin-Ojha, Catherine (2008): Les chrétiens de l'Inde: entre castes et Églises. Paris: Albin Michel.

Clooney, Francis X. (1990): Thinking Ritually. Rediscovering the Pūrva Mìmāmsāa of Jaimini. Vienna: Gerold \& Co. (Publications of the De Nobili Research Library, XVII.)

Coedès, George (1911): Les bas reliefs d'Angkor Vat. Paris. (not seen)

Coedès, George (1924): Les inscriptions de Sukhodaya. Bangkok. (not seen)

Coedès, G. (1964): Les états hindouisés d'Indochine et d'Indonésie. Nouvelle édition revue et mise à jour. Paris: E. de Boccard.

Colas, Gérard (1999): “The reworking of 'Vedic' paradigms in medieval liturgies." The Resources of History. Tradition, Narration and Nation in South Asia. Ed. Jackie Assayag. Paris - Pondichéry: École française d'Extrême-Orient / Institut français de Pondichéry. Pp. 41-50.

Conze, Edward (1951): Buddhism, Its Essence and Development. Oxford: Bruno Cassirer. Second paper back edition, 1974.

Cort, John E. (1993): “An overview of the Jaina Purānas.” Purāṇa Perennis. Reciprocity and Transformation in Hindu and Jaina Texts. Ed. Wendy Doniger. State University of New York Press. Pp. 185-206.

Cort, John E. (1998): "Who is a king? Jain narratives of kingship in medieval western India." = Cort, 1998a: 85-110.

Cort, John E. (ed.)(1998a): Open Boundaries. Jain communities and cultures in Indian history. Albany: State University of New York Press.

Cort, John E. (2010): Framing the Jina. Narratives of icons and idols in Jain history. Oxford University Press.

Coulson, Michael (1981): Three Sanskrit Plays. Harmondsworth: Penguin Books.

Crosby, Kate (2006): "A Theravāda code of conduct for good Buddhists: the Upāsakamanussavinaya.” JAOS 126(2), 177-187.

Cunningham, Alexander (1871): The Ancient Geography of India, I: The Buddhist period, including the campaigns of Alexander, and the travels of Hwen Thsang. London. Réimpression : Indological Book House, Varanasi, 1963.

Dallapiccola, Anna Libera (ed.)(1980): The Stūpa. Its religious, historical and architectural significance. Wiesbaden: Franz Steiner. (Beiträge zur Südasienforschung, Südasien-Institut, Universität Heidelberg, 55.)

Damsteegt, Th. (1989): The pre-Kușāṇa and Kuṣāna inscriptions and the supercession of Prākrit by Sanskrit in North India in general and at Mathurā in particular." Mathurā: The Cultural Heritage. Ed. Doris Meth Srinivasan. New Delhi: American Institute of Indian Studies.

Das, Rahul Peter (2005): "Kaste." Gemeinsame kulturelle Codes in koexistierenden Religionsgemeinschaften. Leucorea-Kolloquium 2003. Ed. Ute Pietruschka. Halle (Saale). (Hallesche Beiträge zur Orientwissenschaft 38 (2004).) Pp. 75-116.

Datta, Swati (née Sen Gupta) (1989): Migrant Brāhmaṇas in Northern India. Their settlement and general impact c. A.D. 475-1030. Delhi etc.: Motilal Banarsidass. 
Davidson, Ronald M. (2002): Indian Esoteric Buddhism. A social history of the Tantric movement. New York: Columbia University Press.

Davidson, Ronald M. (2005): Tibetan Renaissance. Tantric Buddhism in the Rebirth of Tibetan Culture. New York: Columbia University Press.

Davidson, Ronald (2009): Review of Ruegg, 2008. JAOS 129(1), 115-117.

Davis, Richard H. (1998): "The story of the disappearing Jains: Retelling the Śaiva-Jain encounter in medieval South India." = Cort, 1998a: 213-224.

DeCaroli, Robert (2004): Haunting the Buddha. Indian Popular Religions and the Formation of Buddhism. Oxford University Press.

De Casparis, J. G. \& Mabbett, I. W. (1992): "Religion and popular beliefs of Southeast Asia before c. 1500." The Cambridge History of Southeast Asia. Volume One: From early times to c. 1800. Ed. Nicholas Tarling. Cambridge University Press. Pp. 276-339.

De Jong, J. W. (1988): "Buddhism and the equality of the four castes." A Green Leaf. Papers in Honour of Professor Jes P. Asmussen. Leiden: E.J. Brill. Pp. 423-431.

De Jong, J. W. (1997): A Brief History of Buddhist Studies in Europe and America. Tokyo: Kōsei Publishing

Deleu, Jozef (1970): Viyāhapannatti (Bhagavaī): The Fifth Anga of the Jaina Canon. Introduction, critical analysis, commentary \& indexes. Reprint: Motilal Banarsidass, Delhi, 1996. (Lala Sundar Lal Jain Research Series, 10.)

Demiéville, Paul (1937): "Butsuge." Hôbôgirin 3, 203-205.

Demiéville, Paul (1957): Le bouddhisme et la guerre. = Renondeau \& Demiéville, 1957: 347-385.

Demiéville, Paul (1965): "Momies d'Extrême-Orient." Journal des Savants, Troisième centenaire, Paris, pp. 144-170. Reprint: Demiéville, 1973: 407432.

Demiéville, Paul (1973): Choix d'études sinologiques. Leiden: E. J. Brill.

Deshpande, M. (1993): "The changing notion of śișta from Patañjali to Bharț̣hari." AS 47, 95-115. Reprint: Bhartrhari, Philosopher and Grammarian. Proceedings of the First International Conference on Bhartrhari (University of Poona, January 6-8, 1992). Ed. Saroja Bhate and Johannes Bronkhorst. Delhi: Motilal Banarsidass. 1994. Pp. 95-115.

Deshpande, Madhav M. (forthcoming): "Will the winner please stand up: conflicting narratives of a $17^{\text {th }}$ century philosophical debate from Karnataka." Festschrift Trautmann. Ed. Cynthia Talbot.

Dessein, Bart (1999): Samyuktābhidharmahrdaya. Heart of Scholasticism with Miscellaneous Additions. 3 parts. Delhi: Motilal Banarsidass. (Buddhist Tradition Series, 33, 34, 35.)

Dessein, Bart (forthcoming): "Contemplation of the repulsive: bones and skulls as objects of meditation." To appear in the proceedings of the conference "Cultural Histories of Meditation: Practice and Interpretation in a Global Perspective", 12-16 May 2010, Halvorsbøle, Jevnaker, Norway.

Dezsó, Csaba (2007): “A parallel edition of the Nepalese and South Indian recensions of the first act of the Kundamālā (part I)." Newsletter of the NGMCP 3, January-February 2007, pp. 9-24. (http://www.unihamburg.de/fachbereiche- 
einrichtungen/indologie/ngmcp/newsletter_e.html)

Diesel, Anja A. (2006): "Primäre und sekundäre Religion(serfahrung) — das Konzept von Th. Sundermeier und J. Assmann." = Wagner, 2006: 23-41.

Dietz, Siglinde (2000): "Mātrcețas Kaliyugaparikathā." Vividharatnakaraṇaka. Festgabe für Adelheid Mette. Ed. Christine Chojnacki, Jens-Uwe Hartmann \& Volker M. Tschannerl. Swisttal-Odendorf: Indica et Tibetica Verlag. (Indica et Tibetica, 37.) Pp. 173-186.

Doniger O'Flaherty, Wendy (1983): "The image of the heretic in the Gupta Purānas.” Essays on Gupta Culture. Ed. Bardwell L. Smith. Delhi etc.: Motilal Banarsidass. Pp. 107-127.

Doniger, Wendy \& Smith, Brian K. (tr.)(1991): The Laws of Manu. Penguin Books.

Dubois, Abbé J. A. (1906): Hindu Manners, Customs and Ceremonies. Third edition. Fourth impression: Oxford University Press, Delhi etc., 1983.

Dubs, Homer H. (1946): "Han Yü and the Buddha's relic : an episode in medieval Chinese religion." The Review of Religion 11(1), 5-17.

Dumont, Louis (1970): "The conception of kingship in ancient India." Religion/Politics and History in India. Collected papers in Indian sociology. Paris \& The Hague: Mouton. Pp. 62-88.

Dundas, Paul (1991): “The Digambara Jain warrior.” The Assembly of the Listerners: Jains in Society. Ed. Michael Carrithers \& Caroline Humphrey. Cambridge: Cambridge University Press. Pp. 169-186.

Dundas, Paul (1996): "Jain attitudes towards the Sanskrit language." Ideology and Status of Sanskrit. Contributions to the History of the Sanskrit Language.

Ed. Jan E. M. Houben. Leiden etc.: E. J. Brill. (Brill's Indological Library, 13.) Pp. 137-156.

Dundas, Paul (2002): The Jains. Second edition. London \& New York: Routledge.

Dundas, Paul (2006): “A non-imperial religion? Jainism in its 'dark age'.” = Olivelle, 2006: 383-414.

Dundas, Paul (2007): History, Scripture and Controversy in a Medieval Jain Sect. London and New York: Routledge.

Edgerton, Franklin (1924): “The meaning of Sānkhya and Yoga.” American Journal of Philology 45, 1-46.

Edgerton, Franklin (1953): Buddhist Hybrid Sanskrit: Grammar and Dictionary. 2 vols. New Haven. Reprint: Motilal Banarsidass, Delhi, 1977.

Edgerton, Franklin (1965): The Beginnings of Indian Philosophy. Selections from the Rig Veda, Atharva Veda, Upanișads, and Mahābhārata. Translated from the Sanskrit with an introduction, notes and glossarial index. London: George Allen \& Unwin.

Eggeling, Julius (tr.)(1900): The Śatapatha-Brāhmana, according to the text of the Mādhyandina school. Part V: Books XI, XII, XIII, and XIV. Clarendon Press. Reprint: Motilal Banarsidass, Delhi etc.., 1978.

Eltschinger, Vincent (2000): 'Caste' et philosophie bouddhique. Continuité de quelques arguments bouddhiques contre le traitement réaliste des dénominations sociales. Wien: Arbeitskreis für Tibetische und Buddhistische Studien Universität Wien. (Wiener Studien zur Tibetologie und Buddhismuskunde, 47.) 
Eltschinger, Vincent (2001): Dharmakìrti sur les mantra et la perception du supra-sensible. Wien: Arbeitskreis für Tibetische und Buddhistische Studien Universität Wien. (Wiener Studien zur Tibetologie und Buddhismuskunde, 51.)

Eltschinger, Vincent (2008): "Dharmakīrti on mantras and their efficiency." Esoteric Buddhist Studies: Identity in Diversity. Proceedings of the International Conference on Esoteric Buddhist Studies, Koyasan University, 5 Sept. - 8 Sept. 2006. Koyasan University. Pp. 273-289.

Eltschinger, Vincent (2009): “Śañkaranandana’s Sarvajñasiddhi: a preliminary report." Manuscripta Buddhica 1. Sanskrit texts from Giuseppe Tucci's collection. Part 1. Ed. Francesco Sferra. Roma: Istituto Italiano per l'Africa e 1'Oriente. 2008. (Serie Orientale Roma, CIV. ). Pp. 115-156.

Eltschinger, Vincent (forthcoming): "Les oeuvres de Śankaranandana: Nouvelles ressources manuscrites, chronologie relative et identité confessionnelle." Annali dell'Istituto Universitario Orientale di Napoli 66.

Eltschinger, Vincent (forthcoming a): “Apocalypticism, heresy and philosophy: towards a sociohistorically grounded account of sixth century Indian philosophy."

Emmerick, R. E. (1996): The Sūtra of Golden Light. Being a translation of the Suvarnabhāsottamasūtra. $3^{\text {rd }}$ revised edition. Oxford: The Pali text Society. 2001.

Ensink, Jacob (1978): "Śiva-Buddhism in Java and Bali." Buddhism in Ceylon and Studies on Religious Syncretism in Buddhist Countries. (Symposien zur Buddhismusforschung, I.) Ed. Heinz Bechert. Göttingen: Vandenhoeck \& Ruprecht. (Abhandlungen der Akademie der Wissenschaften in Göttingen, philologisch-historische Klasse, Nr. 108.) Pp. 178-198.

Faccenna, Domenico (1980): Butkara I (Swāt, Pakistan) 1956-1962. Part I: Text. Rome: IsMeo. (Reports and Memoirs, III 1.)

Falk, Harry (1986): “Die Prüfung der Beambten im Arthaśāstra." WZKS 30, 5772.

Falk, Harry (2001): "The yuga of the Sphujiddhvaja and the era of the Kuṣānas." Silk Road Art and Archaeology 7, 121-136.

Falk, Harry (2005): "The introduction of stūpa-worship in Bajaur.” Afghanistan: ancien carrefour entre l'est et l'ouest. Ed. Osmund Bopearachchi \& MarieFrançoise Boussac. Turnhout: Brepols. Pp. 347-358.

Falk, Harry (2006): Aśokan Sites and Artefacts. A source-book with bibliography. Mainz am Rhein: Philipp von Zabern.

Falk, Harry (2008): “Gandharan eras." Gandhara. The Buddhist Heritage of Pakistan: Legends, Monasteries, and Paradise. Volume printed on the occasion of the exhibition of that same name. Mainz: Philipp von Zabern. Pp. 70-71.

Faure, Bernard (1991): The Rhetoric of Immediacy : A cultural critique of Chan/Zen Buddhism. Princeton, New Jersey: Princeton University Press.

Faure, Bernard (2008): Bouddhisme et violence. Paris: Le Cavalier Bleu. Fick, Richard (1897): Die sociale Gliederung im nordöstlichen Indien zu Buddha's Zeit, mit besonderer Berücksichtigung der Kastenfrage, vornehmlich auf Grund der Jātaka dargestellt. Kiel: C. F. Haeseler. 
Photomechanischer Nachdruck: Akademische Druck-u. Verlagsanstalt, Graz, 1974.

Finley, Moses I. (1964): "Between slavery and freedom." Comparative Studies in Society and History 6, 233-249. Reprint: Finley, 1981: 116-132.

Finley, Moses I. (1981): Economy and Society in Ancient Greece. Ed. Brent D. Shaw \& Richard P. Saller. London: Chatto \& Windus.

Fisher, Michael H. (ed.)(2007): Visions of Mughal India: An anthology of European travel writing. London: I. B. Tauris.

Fitzgerald, James L. (tr.)(2004): The Mahābhārata. Book 11: The Book of Women; Book 12: The Book of Peace, Part One. Chicago and London: The University of Chicago Press.

Fleet, John Faithfull (1887): Inscriptions of the Early Gupta Kings and their Successors. Reprint: Indological Book House, Varanasi 1970. (CII 3.)

Flügel, Peter (2007): “A short history of Jaina law." International Journal of Jaina Studies 3(4), 1-15.

(http://www.soas.ac.uk/research/publications/journals/ijjs/internationaljournal-of-jaina-studies.html)

Flügel, Peter (2008): “Jaina relic stūpas." Jaina Studies. Newsletter of the Centre of Jaina Studies, SOAS, University of London. Issue 3, March 2008, pp. 18-23.

Flügel, Peter (2010): "Worshipping the ideal king: on the social implications of Jaina conversion stories." Geschichten und Geschichte: Religiöse Geschichtsschreibung in Asien und ihre Verwertung in der religionshistorischen Forschung. Ed. Max Deeg, Oliver Freiberger, Christoph Kleine. Uppsala: Uppsala University. Pp. 1-76.

Flügel, Peter (2010a): “The Jaina cult of relic stūpas.” Numen 57, 389-504. Fogelin, Lars (2006): Archaeology of Early Buddhism. Oxford: Altamira Press. Fosse, Lars Martin (1997): The Crux of Chronology in Sanskrit Literature. Statistics and Indology: A Study of Method. Oslo: Scandinavian University Press.

Foucher, A. (1905): Les bas-reliefs gréco-bouddhiques du Gandhāra. Paris: Ernest Leroux.

Franco, Eli (2007): "Sylvain Lévi's contribution to the study of Indian philosophy." Sylvain Lévi (1863-1935). Études indiennes, histoire sociale. Ed. Lyne Bansat-Boudon \& Roland Lardinois. Paris etc.: Brepols. (Bibliothèque de l'École des Hautes Études, Sciences Religieuses, 130.) Pp. 75-90.

Frauwallner, Erich (1953, 1956): Geschichte der indischen Philosophie. 2 vols. Salzburg.

Frauwallner, Erich (1960): "Sprachtheorie und Philosophie im Mahābhāṣya des Patañjali." WZKSO 4, 92-118. Reprint: Kleine Schriften, Hrsg. Gerhard Oberhammer und Ernst Steinkellner, Franz Steiner, Wiesbaden 1982, pp. 284-310.

Freiberger, Oliver (2000): Der Orden in der Lehre. Zur religiösen Deutung des Sangha im frühen Buddhismus. Wiesbaden: Harrassowitz. (Studies in Oriental Religions, 47.)

Freiberger, Oliver (2006): "Early Buddhism, asceticism, and the politics of the Middle Way." Asceticism and Its Critics. Historical accounts and 
comparative perspectives. Ed. Oliver Freiberger. Oxford University Press. Pp. 235-258.

Fujita, Yoshimichi (2009): "The bodhisattva thought of the Sarvāstivādins and Mahāyāna Buddhism." Acta Asiatica (Bulletin of the Institute of Eastern Culture) 96 (Mahāyāna Buddhism: its origins and reality), 99-120.

Fussman, Gérard (1974): "Quelques problèmes asokéens.” JA 267, 369-389.

Fussman, Gérard (1982): "Pouvoir central et régions dans l'Inde ancienne: le problème de l'empire maurya." Annales, Économies Sociétés Civilisations 37(4), juillet-août 1982, pp. 621-647.

Fussman, Gérard (1987-1988): "Central and provincial administration in ancient India: the problem of the Mauryan empire." Indian Historical Review 14, 43-72.

Fussman, Gérard (1988): "Documents épigraphiques kouchans (V). Buddha et bodhisattva dans l'art de Mathura: deux bodhisattvas inscrits de l'an 4 et l'an 8." BEFEO 77, 5-25.

Fussman, Gérard (1994): "Upāya-kauśalya. L'implantation du bouddhisme au Gandhāra." Bouddhisme et cultures locales. Quelques cas de réciproques adaptations. Ed. Fukui, Fumimasa \& Fussman, Gérard. Paris: École française d'Extrême-Orient. (Études thématiques, 2.) Pp. 17-51.

Fussman, Gérard (2007): "Les Guptas et le nationalisme indien." Cours et travaux du Collège de France, Résumés 2006-2007, pp. 695-711.

Fussman, Gérard (2008): Review of Pollock, 2006. JA 296(1), 163-180.

Gail, Adalbert J. (1994): "Ein Jaina-Mönch beim Parinirvāna des Buddha." Festschrift Klaus Bruhn zur Vollendung des 65. Lebensjahres. Ed. Nalini Balbir \& Joachim K. Bautze. Reinbek: Dr. Inge Wezler, Verlag für Orientalistische Fachpublikationen. Pp. 333-337.

Gautama Dharmasūtra. See Olivelle, 2000.

Geertz, Clifford (1980): Negara. The Theatre State in NineteenthCentury Bali. Princeton University Press.

Gellner, David N. (1992): Monk, Householder and Tantric Priest. Newar Buddhism and its hierarchy of ritual. Cambridge: Cambridge University Press.

Germano, David \& Trainor, Kevin (ed.)(2004): Embodying the Dharma: Buddhist relic veneration in Asia. State University of New York Press.

Gethin, R. M. L. (1992): The Buddhist Path to Awakening : A study of the bodhipakkhiyā dhammā. Leiden etc.: E. J. Brill. (Brill's Indological Library, 7.)

Ghosal, S. N. (1969): "The Ārṣa Prākrit as Hemacandra viewed it." JOIB 18, 304314.

Gillon, Brendan S. (2008): "An early Buddhist text on logic: Fang Bian Xin Lun." Argumentation 22(1), 15-25.

Gokhale, V. V. (1962): "Masters of Buddhism adore the Brahman through nonadoration." IIJ 5, 271-75.

Golzio, Karl-Heinz (1990): "Das Problem von Toleranz und Intoleranz in indischen Religionen anhand epigraphischer Quellen.” Frank-Richard Hamm Memorial Volume. Ed. Helmut Eimer. Bonn: Indica et Tibetica Verlag. (Indica et Tibetica, 21.) Pp. 89-102.

Golzio, Karl-Heinz (2003): Geschichte Kambodschas. München: C. H. Beck.

Golzio, Karl-Heinz (2008): “Zur Datierung des Kușāna-Königs Kaniṣka I.” 
Bauddhasāhityastabakāvalī. Essays and Studies on Buddhist Sanskrit Literature Dedicated to Claus Vogel by Colleagues, Students, and Friends.

Ed. Dragomir Dimitrov, Michael Hahn \& Roland Steiner. Marburg: Indica et Tibetica Verlag. (Indica et Tibetica, 36.) Pp. 79-91.

Gombrich, Richard (1966): "The consecration of a Buddhist image." Journal of Asian Studies 26(1), 23-36.

Gombrich, Richard (1971/1991): Buddhist Precept and Practice : Traditional Buddhism in the rural highlands of Ceylon. Originally published in 1971, Oxford University Press, Oxford. Édition révisée: Motilal Banarsidass, Delhi, 1991.

Gombrich, Richard (1988): Theravāda Buddhism. London and New York: Routledge \& Kegan Paul.

Gombrich, Richard (1996): How Buddhism Began. The Conditioned Genesis of the Early Teachings. London \& Atlantic Highlands, N. J.: Athlone.

Gonda, Jan (1955): "Purohita." Studia Indologica. Festschrift für Willibald Kirfel. Bonn. Pp. 107-124. Reprint: Gonda, 1975: 320-337.

Gonda, Jan (1969): Ancient Indian Kingship from the Religious Point of View. Leiden: E. J. Brill. (First published 1966)

Gonda, Jan (1975): Selected Studies, II: Sanskrit Word Studies. Leiden: E. J. Brill. González-Reimann, Luis (2002): The Mahābhārata and the Yugas. India's great epic poem and the Hindu system of world ages. New York etc.: Peter Lang. 2002. (Asian Thought and Culture, 51.)

Gopinath Rao, T. A. (1926): "Kanyākumāri inscription of Vīra-Rājendra-Deva." EpInd 18 (1925-26), 21-55.

Goyal, S. R. (2006): "History and cultures of Kambuja and Champā as known from their inscriptions." India's Interaction with Southeast Asia. Ed. G. C. Pande. New Delhi: Munshiram Manoharlal. (History of Science, Philosophy and Culture in Indian Civilization, I.3.) Pp. 201-260.

Granoff, Phyllis (1998): The Forest of Thieves and the Magic Garden. An anthology of medieval Jain stories. New Delhi: Penguin Books India.

Gray, David B. (2007): "Compassionate violence? On the ethical implications of Tantric Buddhist ritual." Journal of Buddhist Ethics 14, 239-271. (http://www.buddhistethics.org/)

Greenwald, Alice (1978): "The relic on the spear: historiography and the saga of Duṭthagāman̄ī.” Religion and Legitimation of Power in Sri Lanka. Ed. Bardwell L. Smith. Chambersburg, PA: Anima Books. (non vu)

Griffiths, Paul J.; Hakamaya, Noriaki; Keenan, John P. \& Swanson, Paul L. (1989): The Realm of Awakening. A translation and study of the tenth chapter of Asanga's Mahāyānasanigraha. New York - Oxford: Oxford University Press.

Grönbold, Günter (1996): "Kriegsmaschinen in einem buddhistischen Tantra." Festschrift Dieter Schlingloff zur Vollendung des 65. Lebensjahres. Ed. Friedrich Wilhelm. Reinbek: Dr. Inge Wezler, Verlag für Orientalistische Fachpublikationen. Pp. 63-97.

Gros, François (2009): Deep Rivers. Selected writings on Tamil literature. Chennai: Tara Publishing. (IFP - Publications hors série, 10.)

Grousset, Réné (1932): In the Footsteps of the Buddha. Translated from the French by Mariette Leon. London: George Routledge. 
Guenther, Herbert V. (1963): The Life and Teaching of Nāropa. Translated from the original Tibetan with a philosophical commentary based on the oral transmission. London - Oxord - New York: Oxford University Press.

Guérinot, A. (1908): Répertoire d'épigraphie jaina, précédé d'une esquisse de l'histoire du jainisme d'après les inscriptions. Paris: Imprimerie Nationale.

Gunawardana, R. A. L. H. (1979): Robe and Plough. Monasticism and Economic Interest in Early Medieval Sri Lanka. Tucson: University of Arizona Press.

Gupta, Chitrarekha (1983): The Brahmanas of India. A study based on inscriptions. Delhi: Sundeep Prakashan.

Gupta, Sanjukta \& Gombrich, Richard (1986): "Kings, power and the goddess." South Asia Research 6(2), 123-138.

Hahn, Michael (1982): "Kumāralāta’s Kalpanāmanditikā Drștāntapañkti, Nr. 1: Die Vorzüglichkeit des Buddha." Zentralasiatische Studien 16, 309-336.

Hahn, Michael (1999): Invitation to Enlightenment: Letter to the Great King Kaniṣka by Mätrceța \& Letter to a Disciple by Candragomin. Translated with an Introduction and Notes. Berkeley: Dharma Publishing.

Hahn, Michael (2000): "Śañkarasvāmin's Devatāvimarśastuti." Vividharatnakarandaka. Festgabe für Adelheid Mette. Ed. Christine Chojnacki, Jens-Uwe Hartmann \& Volker M. Tschannerl. SwisttalOdendorf: Indica et Tibetica. (Indica et Tibetica, 37.) Pp. 313-329.

Hahn, Michael (2007): Haribhațta in Nepal. Ten legends from his Jātakamālā and the anonymous Śäkyasimhajātaka. Tokyo: The International Institute for Buddhist Studies. (Studia Philologica Buddhica, Monograph Series, 22.)

Halbfass, Wilhelm (1988): India and Europe. An essay in understanding. Albany: SUNY Press.

Halbfass, Wilhelm (1995): "Early Indian references to the Greeks and the first encounters between Buddhism and the West." When did the Buddha Live? The controversy on the dating of the historical Buddha. Ed. Heinz Bechert. Delhi: Sri Satguru Publications. Pp. 195-209.

Hall, D. G. E. (1968): A History of South-East Asia. London - Melbourne Toronto: MacMillan; New York: St Martin's Press.

Handurukande, Ratna (2000): Three Sanskrit Texts on Caitya Worship in relation to the Ahorātravrata. An edition and synopses in English (with an introduction). Tokyo: The International Institute for Buddhist Studies. (Studia Philologica Buddhica, Monograph Series, 16.)

Hara, Minoru (2007): "Weapons of virtue." Expanding and Merging Horizons. Contributions to South Asian and Cross-Cultural Studies in Commemoration of Wilhelm Halbfass. Ed. Karin Preisendanz. Vienna: Austrian Academy of Sciences Press. (ÖAW, philosophisch-historische Klasse, Denkschriften, 351. Band; Beiträge zur Kultur- und Geistesgeschichte Asiens Nr. 53.) Pp. 613-628.

Harivamśa Purāna of Jinasena. Edited, with Hindi translation, introduction \& appendices, by Pt. Panna Lal Jain. Kashi: Bhāratīya Jñānapītha. 1962. (Jñānapītha Mūrtidevī Jaina Granthamālā, Sanskrit Granth No. 27.)

Harrison, Paul (1992): "Is the dharma-kāya the real 'phantom body' of the Buddha?" JIABS 15(1), 44-94.

Harrison, Paul (1995): "Searching for the origins of the Mahāyāna: what are we looking for?" The Eastern Buddhist 28, 48-69. 
Hartmann, Jens-Uwe (1987): Das Varnārhavarnastotra des Mātṛceța.

Herausgegeben und übersetzt. Göttingen: Vandenhoeck \& Ruprecht. (Abhandlungen der Akademie der Wissenschaften in Göttingen, philologisch-historische Klasse, Dritte Folge, Nr. 160; Sanskrittexte aus den Turfanfunden, 12.)

Hartmann, Jens-Uwe (2004): "Languages." Encyclopedia of Buddhism. Ed. Robert E. Buswell. Macmillan Reference USA. Vol. 1, pp. 452-456.

Hartmann, Jens-Uwe \& Wille, Klaus (2006): "A version of the Śikhālakasūtra/Siñgālovādasutta.” Buddhist Manuscripts, vol. III. (Manuscripts in the Schøyen Collection.) Ed. Jens Braarvig. Oslo: Hermes. Pp. 1-6.

Hazra, Kanai Lal (1995): The Rise and Decline of Buddhism in India. New Delhi: Munshiram Manoharlal.

Hein, Norvin (1989): "Kālayavana, a key to Mathurā’s cultural self-perception." = Srinivasan, 1989: 223-235.

Hemacandra: Yogaśāstra. Ed. Jambuvijaya. 3 vols. Bombay, 1977-1986.

Hemacandra: Trișaștisíalākāpurușacaritamahākāvya. Part 1. Ed. Śrīcaranavijaya. Ahmedabad. 1990.

Herrmann-Pfandt, Adelheid (1996): "Verdienstübertragung im Hīnayāna und Mahāyāna." Suhrllekhāh. Festgabe für Helmut Eimer. Ed. Michael Hahn, Jens-Uwe Hartmann \& Roland Steiner. Swisttal-Odendorf: Indica et Tibetica Verlag. (Indica et Tibetica, 28.) Pp. 79-98.

Hikosaka, Shu (1989): Buddhism in Tamilnadu. A new perspective. Thiruvanmiyur, Madras: Institute of Asian Studies.

Hill, John E. (2009): Through the Jade Gate to Rome. A study of the Silk Routes during the later Han Dynasty, $1^{\text {st }}$ to $2^{\text {nd }}$ centuries $C E$. An annotated translation of the Chronicle on the 'Western Regions' from the Hou Hanshu. www.booksurge.com.

Hiltebeitel, Alf (2006): "Aśvaghoṣa's Buddhacarita: The first known close and critical reading of the Brahmanical Sanskrit epics." JIP 34, 229-286.

Hinüber, Oskar von (1977): "Zur Geschichte des Sprachnamens Pāli." Beiträge zur Indienforschung. Ernst Waldschmidt zum 80. Geburtstag gewidmet. Berlin: Museum für Indische Kunst. Pp. 237-246. (English translation: Selected Papers on Pāli Studies. Oxford: The Pali Text Society. 1994. Pp. 76-90.)

Hinüber, Oskar von (1981): "Namen in Schutzzaubern aus Gilgit.” StII 7, 163171. (= K1Sch II pp. 722-730.)

Hinüber, Oskar von (1983): "Die Bedeutung des Handschriftenfundes bei Gilgit." ZDMG, Supplement V : XXI. Deutscher Orientalistentag vom 24. bis 29. März 1980 in Berlin: Vorträge. Hrsg. Fritz Steppat. Wiesbaden: Franz Steiner. Pp. 47-66. (= K1Sch II pp. 668-687.)

Hinüber, Oskar von (1983/1994): "The oldest literary language of Buddhism." Selected Papers on Pāli Studies. Oxford: The Pali Text Society. Pp. 177194.

Hinüber, Oskar von (1986): Das ältere Mittelindisch in Überblick. Wien: ÖAW. Hinüber, Oskar von (1988): Die Sprachgeschichte des Pāli im Spiegel der südostasiatischen Handschriftenüberlieferung. Untersuchungen zur Sprachgeschichte und Handschriftenkunde des Pāli I. Stuttgart: Franz 
Steiner. (Akademie der Wissenschaften und der Literatur, Mainz. Abhandlungen der Geistes- und Sozialwissenschaftlichen Klasse, Jhrg. 1988, Nr. 8.)

Hinüber, Oskar von (1989): "Origin and varieties of Buddhist Sanskrit." Dialectes dans les littératures indo-aryennes. Ed. Colette Caillat. Paris: Édition-Diffusion de Boccard. (Publications de 1'Institut de Civilisation Indienne, série in- $8^{\circ}$, fasc. 55.) Pp. 341-367. (= K1Sch I pp. 554-580.)

Hinüber, Oskar von (1995): "Linguistic considerations on the date of the Buddha." When did the Buddha Live? The controversy on the dating of the historical Buddha. Ed. Heinz Bechert. Delhi: Sri Satguru Publications. Pp. 185-194. (= K1Sch I pp. 479-488.)

Hinüber, Oskar von (1996): A Handbook of Pāli Literature. Berlin - New York: Walter de Gruyter. (Indian Philology and South Asian Studies, 2.)

Hinüber, Oskar von (1998): Entstehung und Aufbau der Jātaka-Sammlung. Studien zur Literatur des Theravāda-Buddhismus I. Stuttgart: Franz Steiner. (Akademie der Wissenschaften und der Literatur. Abhandlungen der Geistes- und Sozialwissenschaftlichen Klasse, Jahrgang 1998 nr. 7.)

Hinüber, Oskar von (2002): "The vocabulary of Buddhist Sanskrit: problems and perspectives." Proceedings of the British Academy 116 ("Indo-Iranian Languages and Peoples"), 151-164. (= K1Sch II pp. 589-602.)

Hinüber, Oskar von (2003): Beiträge zur Erklärung der Senavarma-Inschrift. Mainz: Akademie der Wissenschaften und der Literatur; Stuttgart: Franz Steiner. (Akademie der Wissenschaften und der Literatur, Abhandlungen der Geistes- und sozialwissenschaftlichen Klasse, Jahrgang 2003, Nr. 1.)

Hinüber, Oskar von (2004): "Les documents épigraphiques indiens: difficultés de leur interprétation - exemples concernant l'irrigation." Comptes rendus de l'Académie des Inscriptions \& Belles-lettres, séances de l'année 2004 avril-juin. Paris: de Boccard. Pp. 989-1011. (= K1Sch II pp. 846-868.)

Hinüber, Oskar von (2005): "Der bhūmicchidranyāya." ZDMG 155, 483-495. (= K1Sch 833-845.

Hinüber, Oskar von (2007): Review of Politische Strukturen im Guptareich (300550 n. Chr.) by Fred Virkus. IIJ 50, 183-192.

Hinüber, Oskar von (2008): "The foundation of the Bhikkhunīsamgha: a contribution to the earliest history of Buddhism." Annual Report of The International Research Institute for Advanced Buddhology at Soka University for the Academic Year 2007, pp. 3-35.

Hinüber, Oskar von (2008a): "Hoary past and hazy memory: on the history of early Buddhist texts." JIABS 29(2), 2006 (2008), 193-210.

Hinüber, Oskar von (2008b): "Indien." Handwörterbuch der antiken Sklaverei. Lieferung I-II. Ed. Heinz Heinen. Stuttgart: Franz Steiner.

Hinüber, Oskar von (2009): "Verwischte Spuren: Der Gebrauch buddhistischer Texte nach dem Zeugnis von Literatur, Inschriften und Dokumenten." Sakrale Texte: Hermeneutik und Lebenspraxis in den Schriftkulturen. Ed. Wolfgang Reinhard. München: C. H. Beck. Pp. 153-173 \& 325-335.

Hinüber, Oskar von (2009a): "Cremated like a king: the funeral of the Buddha within the ancient Indian cultural context." Journal of the International College for Postgraduate Buddhist Studies 13, 33-66. 
Hinüber, Oskar von (2009b): "La légende de la vie du Bouddha. Quelques pensées sur les recherches d'Alfred Foucher: résultats acquis et progrès entamés." Bouddhismes d'Asie: Monuments et littératures. Ed. PierreSylvain Filliozat \& Jean Leclant. Paris: AIBL - Diffusion De Boccard. Pp. 141-151.

Hirakawa, Akira (1963): "The rise of Mahāyāna Buddhism and its relationship to the worship of stūpas." Memoirs of the Research Department of the Toyo Bunko 22, 57-106.

Hocart, A. M. (1931): The Temple of the Tooth in Kandy. London: Luzac. (Memoirs of the Archaeological Survey of Ceylon, vol. IV (ou III?).)

Hoernle, A. F. Rudolf (1880): The Prákrita-Lakshanam or Chanda's Grammar of the Ancient (ársha) Prákrit. Part I: Text with a critical introduction and indexes. Calcutta: Asiatic Society.

Hopkins, Jeffrey (1998): Buddhist Advice for Living \& Liberation. Nāgārjuna's Precious Garland. Analyzed, translated, and edited. Ithaca, New York: Snow Lion Publications.

Houben, Jan E. M. (1997): "Bhartrhhari's Vākyapadīya and the ancient Vrrtti (2): The Vedic background of the author of the Vākyapadīya-Vrtti." StII 21, 71-77.

Houben, Jan E. M. (1998): "Bhartrhhari's Vākyapadīya and the ancient Vṛtti (1): The Vrtti and Vrșabhadeva's Paddhati on Vākyapadīya 1.46a àtmabhedam / àtmabhedas ..." ABORI 78 [1997], 177-198.

Houben, Jan E. M. (1999): "On syntactic and stylistic evidence regarding the authorship of the Vākyapadīya-Vrttti (Bhartrhhari's Vākyapadīya and the ancient Vrtti, 3)." WZKS 43, 167-197.

Huber, Édouard (1908): Açvaghoṣa, Sûtrâlamkāra. Traduit en français sur la version chinoise de Kumârajîva. Paris: Ernest Leroux.

Hultzsch, E. (1925): Inscriptions of Asoka. New edition. (Corpus Inscriptionum Indicarum, 1.) Reprint: Indological Book House, Delhi - Varanasi, 1969.

Inden, Ronald (1992): "Changes in the Vedic priesthood." Ritual, State and History in South Asia. Essays in Honour of J. C. Heesterman. Ed. A. W. van den Hoek, D. H. A. Kolff, M. S. Oort. Leiden: Brill. (Memoirs of the Kern Institute, 5.) Pp. 556-577.

Ingalls, Daniel H.; Masson, Jeffrey Moussaieff \& Patwardhan, M. V. (tr.)(1990): The Dhvanyāloka of Ānandavardhana with the Locana of Abhinavagupta. Edited with an introduction by Daniel H. Ingalls. Cambridge, Massachusetts \& London, England: Harvard University Press. (HOS 49.)

Irwin, John (1979): "The stūpa and the cosmic axis : the archaeological evidence." South Asian Archaeology 1977. Vol. 1. Ed. Maurizio Taddei. Naples. (Istituto Universitario Orientale, Seminario di Studi Asiatici, Series Minor, VI.) Pp. 799-845.

Iyer, K. A. Subramania (1964): "Bhartrhari on apabhramśa." Vishveshvarananda Indological Journal 2 (2), 242-246.

Jaini, Padmanabh S. (1977): "Jina Rṣabha as an avatāra of Viṣnu." BSOAS 40(2), 321-337. Reprint: Jaini, 2000: 325-349.

Jaini, Padmanabh S. (1979): The Jaina Path of Purification. Delhi etc.: Motilal Banarsidass. 
Jaini, Padmanabh S. (1980): "The disappearance of Buddhism and the survival of Jainism: a study in contrast." Studies in History of Buddhism. Ed. A. K. Narain. Delhi: B. R. Publishing. Pp. 81-91. Reprint: Jaini, 2001: 139-153. Jaini, Padmanabh (1991): "Is there a popular Jainism?" The Assembly of the Listerners: Jains in Society. Ed. Michael Carrithers \& Caroline Humphrey. Cambridge: Cambridge University Press. Pp. 187-199. Reprint: Jaini, 2000: 267-279.

Jaini, Padmanabh S. (1995): “Jaina monks from Mathurā: literary evidence for their identification on Kusāna sculptures.” BSOAS 57(3), 479-494. Reprint: Jaini, 2000: 297-322. (references to the reprint)

Jaini, Padmanabh S. (2000): Collected Papers on Jaina Studies. Delhi: Motilal Banarsidass.

Jaini, Padmanabh S. (2001): Collected Papers on Buddhist Studies. Delhi: Motilal Banarsidass.

Jaini, Padmanabh S. (2007): "A note on micchādițthi in Mahāvamsa 25.110." JPTS 29, 153-168.

Jambuddīvapaṇnattī. In: Uvaniga Suttāni IV (Part II). Ed. Yuvācārya Mahāprajña. Ladnun: Jain Vishva Bharati. 1989. Pp. 357-588.

Jamspal, Lozang; Chophel, Ngawang Samten \& Santina, Peter della (1978): Nāgārjuna's Letter to King Gautamīputra. Delhi etc.: Motilal Banarsidass.

Jan, Yün-hua (1984): "Rājadharma ideal in Yogācāra Buddhism." Religion and Society in Ancient India. Sudhakar Chattopadhyaya Commemoration Volume. Ed. Pranabananda Jash et al. Calcutta: Roy \& Chowdhury. Pp. 221-234.

Jayaswal, K. P. \& Banerji, R. D. (1933): “The Hāthīgumphā inscription of Khāravela." EpInd 20 (1929-30), 71-89.

Jha, D. N. (2002): The Myth of the Holy Cow. London - New York: Verso.

Jha, Dwijendra Narayan (2006): "Looking for a Hindu Identity." http://www.stopfundinghate.org/resources/DNJhaHinduIdentity.pdf

Johnson, W. J. (2003): “The 'Jina experience': a different approach to Jaina image worship." Jainism and Early Buddhism. Essays in Honor of Padmanabh S. Jaini. Part I. Ed. Olle Qvarnström. Fremont, California: Asian Humanities Press. Pp. 217-230.

Johnston, E. H. (1930): "Some Sāmkhya and Yoga conceptions of the Śvetāśvatara Upaniṣad.” JRAS 1930, pp. 855-878.

Johnston, E. H. (1936): The Buddhacarita or Acts of the Buddha. Part I: Sanskrit text of cantos I-XIV; Part II: Cantos i to xiv translated from the original Sanskrit supplemented by the Tibetan version, together with an introduction and notes. Lahore. Reprint: Motilal Banarsidass, Delhi, 1984.

Johnston, E. H. (1944): “Some Sanskrit inscriptions of Arakan.” BSOAS 11(2), 357-385.

Jones, J. J. (tr.)(1949-1956): The Mahāvastu, translated from the Buddhist Sanskrit. London: Luzac.

Joshi, Lal Mani (1977): Studies in the Buddhistic Culture of India (during the seventh and eighth centuries A.D.). Second revised edition. Delhi etc.: Motilal Banarsidass.

Kalhaṇa: Rājataraingiṇī. Ed. Vishva Bandhu. Part I. Hoshiarpur: Vishveshvaranand Vedic Research Institute. 1963. (W. I. Series, 5.) 
Kane, Pandurang Vaman: History of Dharmaśāstra. Vol. I, revised and enlarged, part 1, 1968; part 2, 1975. Vol. II, second edition, 2 parts, 1974. Vol. III, second edition, 1973. Vol. IV, second edition, 1973. Vol. V, second edition, part 1, 1974; part 2, 1977. Poona: Bhandarkar Oriental Research Institute.

Kangle, R. P. (1965, 1969, 1972): The Kauțilīya Arthaśāstra. 3 parts. Bombay University. Reprint: Motilal Banarsidass, Delhi, 1986-1988.

Kant, Shashi (1971/2000): The Hāthīgumphā Inscription of Khāravela and the Bhabru Edict of Aśoka. A critical study. Second revised edition 2000. New Delhi: D. K. Printworld.

Karttunen, Klaus (1997): India and the Hellenistic World. Helsinki: The Finnish Oriental Society. (Studia Orientalia, 83.)

Kataoka, Kei (2007): "Was Bhatța Jayanta a Paippalādin?” The Atharvaveda and its Paippalādaśākhā. Historical and philological papers on a Vedic tradition. Ed. Arlo Griffiths \& Annette Schmiedchen. Aachen: Shaker Verlag. (Geisteskultur Indiens. Texte und Studien, 11.) Pp. 313-327.

Katz, David S. (1982): Philo-Semitism and the Readmission of the Jews to England 1603-1655. Oxford: Clarendon Press.

Kern, Heinrich (1882): Der Buddhismus und seine Geschichte in Indien. Eine Darstellung der Lehren und Geschichte der buddhistischen Kirche. Vom Verfasser autorisirte Uebersetzung von Hermann Jacobi. Erster Band. Leipzig: Otto Schulze.

Kern, H. (1896): Manual of Indian Buddhism. Reprint used: Indological Book House, Varanasi - Delhi, 1972.

Khoroche, Peter (1989): Once the Buddha was a Monkey: Ārya Sūra's Jātakamālā translated from the Sanskrit. Chicago - London: The University of Chicago Press.

Kieffer-Pülz, Petra (2000): “Die buddhistische Gemeinde.” Der Buddhismus I. Der indische Buddhismus und seine Verzweigungen. Von Heinz Bechert et al. Stuttgart: W. Kohlhammer. (Die Religionen der Menschheit, vol. 24,1.) Pp. 281-402.

Kielhorn, F. (1892): "The Mungir copper-plate grant of Devapāladeva.” The Indian Antiquary 21, 253-258.

Kielhorn, F. (1906): "Junāgaḍh rock inscription of Rudradāman; the year 72." EpInd 8 (1905-06), 36-49.

King, Winston L. (1992): Theravāda Meditation: The Buddhist transformation of Yoga. First Indian edition. Delhi: Motilal Banarsidass.

Kirfel, Willibald (1924): "Studien zu Teilen des Jainakanons." Zeitschrift für Indologie und Iranistik 3, 50-80. Reprint: Kleine Schriften, pp. 19-49.

Kleine, Christoph (2003): "Üble Mönche oder wohltätige Bodhisattvas?" Zeitschrift für Religionswissenschaft 11, 235-258.

Klimburg-Salter, Deborah (1989): The Kingdom of Bāmiyān. Buddhist art and culture of the Hindu Kush. Naples - Rome: Istituto Universitario Orientale $\&$ Istituto Italiano per il Medio ed Estremo Oriente.

Kloppenborg, Ria (1990): "The Buddha's redefinition of tapas (ascetic practice)." BSR 7 (1-2), 49-73.

Konow, Sten (1929): Kharoshṭī Inscriptions with the exception of those of Aśoka. (Corpus Inscriptionum Indicarum, 2.1.) Reprint: Indological Book House, 
Varanasi, 1969.

Kopf, L. (1956): "Religious influences on medieval Arabic philology." Studia Islamica 5, 33-59.

Koskikallio, P. (1994): “When time turns: Yugas, ideologies, sacrifices.” Studia Orientalia 73, 253-271.

Kottkamp, Heino (1992): Der Stupa als Repräsentation des buddhistischen Heilsweges. Untersuchungen zur Entstehung und Entwicklung architektonischer Symbolik. Wiesbaden: Otto Harrassowitz. (Studies in Oriental Religions, 25.)

Kulke, Harmann (1985): "Mahārājas, mahants and historians. Reflections on the historiography of early Vijayanagara and Sringeri." Vijayanagara - City and Empire. New currents of research. Ed. Anna Libera Dallapiccola. Volume I. Stuttgart: Steiner Verlag Wiesbaden. (Beiträge zur Südasienforschung, Südasien-Institut, Universität Heidelberg, Band 100.) Pp. 120-143.

Kulke, Hermann (1986): "The early and the imperial kingdom in Southeast Asian history." Southeast Asia in the 9th to 14th Centuries. Ed. David G. Marr and A. C. Milner. Singapore: Institute of Southeast Asian Studies / Canberra: Research School of Pacific Studies, Australian National University. Pp. 1-22. Reprint: Kulke, 1993: 262-293. (References to the reprint.)

Kulke, Hermann (1986a): "Max Weber's contribution to the study of 'Hinduization' in India and 'Indianization' in Southeast Asia." Recent Research on Max Weber's Studies on Hinduism. Ed. D. Kantowsky. Munich: Weltforum-Verlag. Pp. 97-116. Reprint: Kulke, 1993: 240-261. (References to the reprint.)

Kulke, Hermann (1990): "Indian colonies, Indianization or cultural convergence? Reflections on the changing image of India's role in South-East Asia." Semaian 3, 1990, pp. 8-32

Kulke, Hermann (1993): Kings and Cults. State formation and legitimation in India and Southeast Asia. Delhi: Manohar. Reprint 2001.

Kulke, Hermann (forthcoming): "From Ashoka to Jayavarman VII: some reflections on the relationship between Buddhism and the state in India and Southeast Asia."

Kulke, Hermann \& Rothermund, Dietmar (1998): A History of India. Third edition. London \& New York: Routledge.

Kumar, Pushpendra (1999): Descriptive Catalogue of Sanskrit Inscriptions (from 300 B.C. to $19^{\text {th }}$ century A.D.). Vol. 2: 100 B.C. to 300 A.D. Delhi: Nag Publishers.

Kuwayama, Shoshin (1976): “The Turki Sāhis and relevant Brahmanical sculptures in Afghanistan." East and West 26(1-2), 375-407.

Kuwayama, Shoshin (1999): "Historical notes on Kāpiśī and Kābul in the sixtheighth centuries.” Zinbun 34(1), 25-77.

Laidlaw, James (1995): Riches and Renunciation. Religion, economy, and society among the Jains. Oxford.

Lakoff, George (2004): Don't Think of an Elephant! Know your values and frame the debate. White River Junction, Vermont: Chelsea Green. 
Lamotte, Étienne (1938/1973): La Somme du Grand Véhicule d'Asanga (Mahāyānasamgraha). Tome II : Traduction et commentaire. Louvain-laNeuve: Université de Louvain, Institut Orientaliste.

Lamotte, Étienne (1949-80): Le traité de la grande vertu de sagesse. 5 tomes. Louvain: Institut Orientaliste.

Lamotte, Étienne (1958): Histoire du bouddhisme indien. Des origines à l'ère Śaka. Louvain: Institut Orientaliste. (Bibliothèque du Muséon, 43.)

Lancaster, Lewis R. (1974): "An early Mahayana sermon about the body of the Buddha and the making of images." Artibus Asiae 36, 287-291.

Landes, David S. (1998): The Wealth and Poverty of Nations. Why some are so rich and some so poor. New York - London: W. W. Norton.

Lang, Karen (ed., tr.)(1986): Arryadeva's Catuhśataka. On the Bodhisattva's cultivation of merit and knowledge. Copenhagen: Akademisk Forlag. (Indiske Studier, 7.)

Lang, Karen C. (1992): "Āryadeva and Candrakīrti on the dharma of kings." AS 46(1; Études bouddhiques offertes à Jacques May), 232-243.

Larson, Gerald James \& Bhattacharya, Ram Shankar (1987): Encyclopedia of Indian Philosophies, IV: Sāmkhya. A dualist tradition in Indian philosophy. Delhi etc.: Motilal Banarsidass.

La Vallée Poussin, Louis de (1925): "Notes bouddhiques, VI, §3: Les fidèles laïcs ou upāsakas." Bulletins de la classe des lettres et des sciences morales et politiques, Académie Royale de Belgique, 5e série, tome 11, pp. 15-34.

La Vallée Poussin, Louis de (1927): La morale bouddhique. Paris: La Nouvelle Imprimerie Nationale. Réimpresssion: Éditions Dharma, 2001.

La Vallée-Poussin (1930): L'Inde aux temps des Mauryas et des barbares, Grecs, Scythes, Parthes et Yue-tchi. Paris: E. de Boccard. (Histoire du Monde, 6.)

Legge, James (1886): A Record of Buddhistic Kingdoms. Being an account by the Chinese monk Fâ-hien of his travels in India and Ceylon (A.D. 399-414) in search of the Buddhist books of discipline, translated and annotated. Réimpression: Paragon Books, New York, 1965.

Leumann, Ernst (1883): Das Aupapātika Sūtra, I. Theil. Einleitung, Text und Glossar. Nachdruck: Klaus Reprint, Nendeln, Liechtenstein. $1966 .$. Leipzig.

Lévi, Sylvain (1896): “Notes sur les Indo-Scythes.” JA série 9, tome 8, pp. 444484.

Lévi, Sylvain (1902): "Sur quelques termes employés dans les inscriptions des Ksatrapas.” JA, neuvième série, 19, 95-125.

Lévi, Sylvain (1915): "Le catalogue géographique des Yakșa dans la Mahāmāyūrī." JA, onzième série, tome V, pp. 19-138.

Lévi, Sylvain (éd., tr.)(1932): Mahākarmavibhaìga et Karmavibhañgopadeśa. Paris: Ernest Leroux.

Lévi, Sylvain (1932a): "Note sur des manuscrits sanscrits provenant de Bamiyan (Afghanistan), et de Gilgit (Cachemire)." JA 220, 1-45.

Lewis, Todd T. (1994): “A modern guide for Mahāyāna Buddhist life-cycle rites: the Nepāl Jana Jīvan Kriyā Paddhati.” IIJ 37, 1-46.

Li, Rongxi (tr.)(1996): The Great Tang Dynasty Record of the Western Regions. Translated by the Tripitaka-Master Xuanzang under Imperial Order. Composed by Śramaṇa Bianji of the Great Zongchi Monastery. (Taishō, 
Volume 51, Number 2087. Berkeley: Numata Center for Buddhist Translation and Research. (BDK English Tripitaka 79.)

Li, Rongxi (tr.)(2000): Buddhist Monastic Traditions of Southern Asia. A Record of the Inner Law sent home from the South Seas by Śramana Yijing. Berkeley: Numata Center for Buddhist Translation and Research. (BDK English Tripitaka 93-I.)

Li, Rongxi (2002): "The Journey of the Eminent Monk Faxian (Taishō, volume 51, number 2085)." In: Lives of Great Monks and Nuns. Berkeley: Numata Center for Buddhist Translation and Research. (BDK English Tripitaka 76-III, IV, V, VI, VII.) Pp. 157-214.

Lincoln, Bruce (2007): Religion, Empire, and Torture. The case of Achaemenian Persia. Chicago \& London: The University of Chicago Press.

Lingat, Robert (1989): Royautés bouddhiques. Aśoka et La fonction royale à Ceylan. Ed. Gérard Fussman and Éric Meyer. Paris: École des Hautes Études en Sciences Sociales.

Lloyd, G. E. R. (2009): Disciplines in the Making. Cross-cultural perspectives on elites, learning, and innovation. Oxford University Press.

Lopez, Donald S. (1998): Prisoners of Shangri-La. Tibetan Buddhism and the West. Chicago \& London: The University of Chicago Press.

Lopez, Donald S. (2008): Buddhism \& Science. A guide for the perplexed. Chicago \& London: The University of Chicago Press.

Loucel, Henri (1963-64): "L’origine du langage d'après les grammairiens arabes, I-IV." Arabica 10, 1963, 188-208 \& 253-281; 11, 1964, 57-72 \& 151-187.

Lubin, Timothy (2005): "The transmission, patronage, and prestige of Brahmanical piety from the Mauryas to the Guptas." Boundaries, Dynamics and Construction of Traditions in South Asia. Ed. Federico Squarcini. Firenze University Press / Munshiram Manoharlal. Pp. 77-103.

Luce, Edward (2006): In Spite of the Gods. The strange rise of modern India. London: Little, Brown.

Lüders, H. (1912/1973): A List of Brahmi Inscriptions from the earliest times to about A.D. 400 with the exeception [sic] of those of Asoka. VaranasiDelhi: Indological Book House. 1973. (This appears to be a reprint of "A List of Brahmi Inscriptions" that came out in 1912 as an Appendix to EpInd 10.)

Lüders, Heinrich (1930): “Kātantra und Kaumāralāta." Sitzungsberichte der preussischen Akademie der Wissenschaften, Jahrgang 1930, Philosophischhistorische Klasse, pp. 482-538. (= Philologica Indica (Festgabe Lüders). Göttingen: Vandenhoeck \& Ruprecht. 1940. Pp. 659-721.)

Mabbett, I. W. (1977): "Varnas in Angkor and the Indian caste system." Journal of Asian Studies 36(3), 429-442.

Mabbett, I. W. (1977a): "The 'Indianization' of Southeast Asia: Reflections on the historical sources." Journal of Southeast Asian Studies 8(2), 143-161.

Mabbett, Ian (1986): "Buddhism in Champa." Southeast Asia in the 9th to 14th centuries. Ed. David G. Marr and A. C. Milner. Singapore: Institute of Southeast Asian Studies / Canberra: Research School of Pacific Studies, Australian National University. Pp. 289-313.

MacDonald, Anne (2007): "Revisiting the Mūlamadhyamakakārikā: text-critical proposals and problems." Studies in Indian Philosophy and Buddhism 14, 
25-55.

Macdonell, Arthur Anthony \& Keith, Arthur Berriedale (1912): Vedic Index of Names and Subjects. 2 vols. London. Reprint: Motilal Banarsidass, Delhi etc., 1982.

Mahadevan, Iravatham (2003): Early Tamil Epigraphy. From the earliest times to the sixth century A.D. Cambridge, Massachusetts \& London, England: Harvard University Press. (Harvard Oriental Series, 62.)

Majumdar, R. C. (ed.)(1951): The History and Culture of the Indian People, II: The Age of Imperial Unity. Bombay: Bharatiya Vidya Bhavan.

Malamoud, Charles (2005): Féminité de la parole. Études sur l'Inde ancienne. Paris: Albin Michel.

Malinar, Angelika (2007): The Bhagavadgītā. Doctrines and contexts. Cambridge University Press.

Manu: Laws of Manu. See Olivelle, 2005.

Martin, Dan (2007): "Devotional, covenantal and yogic: Three episodes in the religious use of alphabet and letter from a millennium of Great Vehicle Buddhism." The Poetics of Grammar and the Metaphysics of Sound and Sign. Ed. S. La Porta \& D. Shulman. Leiden - Boston: Brill. (Jerusalem Studies in Religion and Culture, 6.) Pp. 201-229.

McClish, Mark Richard (2009): Political Brahmanism and the State: A Compositional History of the Arthaśāstra. Unpublished doctoral dissertation, University of Texas, Austin.

Mears, Ray (2007): Wild Food. A DVD accompanying the BBC television series. Etchingham, East Sussex: Woodlore.

Meisig, Konrad (1988): Das Sūtra von den vier Ständen. Das Aggañña-Sutta im Licht seiner chinesischen Parallelen. Wiesbaden: Otto Harrassowitz. (Freiburger Beiträge zur Indologie, 20.)

Meister, Michael W. (2010): Temples of the Indus. Studies in the Hindu Architecture of Ancient Pakistan. Leiden etc.: Brill. (Brill's Indological Library, 35.)

Mertens, Annemarie (2000): "Beobachtungen zur Herrschaftslegimitation im Anjkor-Reich: die buddhistisch orientierte Vat-Sithor-Inschrift von Jayavarman V." Vividharatnakarandaka. Festschrift für Adelheid Mette. Ed. Christine Chojnacki, Jens-Uwe Hartmann \& Volker M. Tschannerl. Swisttal-Odendorf. (Indica et Tibetica, 37.) Pp. 395-411.

Mertens, Annemarie (2005): "varna - ein panindischer Identitätsbegriff? Zur Bedeutung des Vier-Stände-Modells für die indischen Religionen." Mitteilungen für Anthropologie und Religionsgeschichte (MARG) 17 (Religionskonflikte - Religiöse Identität), 237-270.

Meulenbeld, G. Jan (1999): A History of Indian Medical Literature. Volume I A. Groningen: Egbert Forsten.

Michaels, Axel (1998): Der Hinduismus. Geschichte und Gegenwart. München: C. H. Beck.

Misra, B. N. (1998): Nālandā: Sources and Background. Vol. 1. Delhi: B.R. Publishing Corporation.

Mohavicchedan̄ by Kassapatthera of Cola. Edited by A. P. Buddhadatta and A. K. Warder. London: Luzac \& Co. 1961. (Pali Text Society.)

Mookerji, Radha Kumud (1947): Ancient Indian Education (Brahmanical and 
Buddhist). London: MacMillan.

Mounin, Georges (1985): Histoire de la linguistique des origines au XXe siècle. 4 e édition corrigée. Paris: Presses Universitaires de France.

Mukhopadhyaya, Sujitkumar (ed.)(1954): The Sārdūlakarṇāvadāna. Santiniketan: Viśvabharati.

Mukhopadhyaya, Sujitkumar (1967): “A critical study of the Śārdūlakarnāvadāna: from the Brāhmaṇic literary sources." VishvaBharati Annals 12(1), 1-108.

Murr, Sylvia (1987): L'Inde philosophique entre Bossuet et Voltaire. I : Moeurs et coutumes des indiens (1777), un inédit du Père G.-L. Coeurdoux s.j. dans la version de N.-J. Desvaulx. II : L'indologie du Père Coeurdoux : stratégies, apologétique et scientificité. Paris: Adrien-Maisonneuve. (Publications de l'École Française d'Extrême-Orient, 146.)

Murthy, R. S. \& Nagarajan, M. S. (ed.)(1998): Buddhism in Tamil Nadu. Collected papers. Chemmancherry, Chennai: Institute of Asian Studies.

Mus, P. (1934): “Cultes indiens et indigènes au Champa.” BEFEO 33 (1933), 367-410.

Nāgārjuna: Letter to King Gautamīputra. See Jamspal et al., 1978.

Nāgārjuna: Ratnāval̄ / Precious Garland. See Hopkins, 1998.

Nakamura, Hajime (1980): Indian Buddhism. A survey with bibliographical notes. Japan: Kufs Publication.

Namisādhu. In: Kāvyālañkāra (A Treatise on Rhetoric) of Rudrața, with the Sanskrit commentary of Namisādhu, edited by Pt. Rāmadeva Śukla. Varanasi: Chowkhamba Vidyabhawan. (Vidyabhawan Rastrabhasha Granthamala, 136.)

Ñānamoli, Bhikkhu \& Bodhi, Bhikkhu (tr.)(1995): The Middle Length Discourses of the Buddha: a new translation of the Majjhima Nikāya. Boston: Wisdom Publications.

Nath, Vijay (2001): 'From 'Brahmanism' to 'Hinduism': negotiating the myth of the Great Tradition." Social Scientist 29(3/4), 19-50.

Nattier, Jan (2003): A Few Good Men. The Bodhisattva Path according to The Inquiry of Ugra (Ugrapariprcchā). A study and translation. Honolulu: University of Hawai'i Press.

Nemec, John (2007): Review of Pollock, 2006. Journal of the American Academy of Religion 75, 207-211.

Nicholson, Hugh (2010): "The shift from agonistic to non-agonistic debate in early Nyāya.” JIP 38(1), 75-95.

Nitti-Dolci, Luigia (1938): Les grammairiens prakrits. Paris: AdrienMaisonneuve.

Njammasch, Marlene (2001): Bauern, Buddhisten und Brahmanen. Das frühe Mittelalter in Gujarat. Wiesbaden: Harrassowitz.

Noble, David F. (1999): The Religion of Technology. The divinity of man and the spirit of invention. New York etc.: Penguin.

Norman, K. R. (1976): "The language in which the Buddha taught." Buddhism and Jainism. Ed. Harish Chandra Das et al. Institute of Oriental and Orissan Studies. Part I. Pp. 15-23. Reprint: Collected Papers, Volume II. Oxford: The Pali Text Society. 1991. Pp. 84-98. 
Norman, K. R. (1980): "The dialects in which the Buddha preached." Die Sprache der ältesten buddhistischen Überlieferung (Symposien zur

Buddhismusforschung, II.) Ed. Heinz Bechert. Göttingen: Vandenhoeck \& Ruprecht. Pp. 61-77. Reprint: Collected Papers, Volume II. Oxford: The Pali Text Society. 1991. Pp. 128-147.

Norman, K. R. (1991): "The role of the layman according to the Jain canon." The Assembly of Listeners: Jains in Society. Ed. Michael Carrithers \& Caroline Humphrey. Cambridge University Press. Pp. 31-39. Reprint: Collected Papers, Volume IV. Oxford: The Pali Text Society. 1993. Pp. 175-184.

Norman, K. R. (2006): A Philological Approach to Buddhism. The Bukkyō Dendō Kyōkai Lectures 1994. Lancaster: The Pali Text Society.

Oberlies, Thomas (1989): Studie zum Cāndravyākarana. Eine kritische Bearbeitung von Candra IV.4.52-148 und V.2. Stuttgart: Franz Steiner. (Alt- und Neu-Indische Studien, 38.)

Oberlies, Thomas (2001): Pāli. A grammar of the language of the Theravāda Tipitaka. With a concordance to Pischel's Grammatik der PrakritSprachen. Berlin - New York: Walter de Gruyter. (Indian Philology and South Asian Studies, 3.)

Ohira, Suzuko (1994): A Study of the Bhagavatīsūtra: a chronological analysis. Ahmedabad: Prakrit Text Society. (Prakrit Text Series, 28.)

Oldenberg, Hermann (tr.)(1886): The Grihya-Sutras. Rules of Vedic domestic ceremonies. Part I. Oxford University Press. Reprint: Motilal Banarsidass, Delhi, 1989.

Olender, Maurice (1989): Les langues du Paradis. Aryens et Sémites: un couple providentiel. Gallimard, Le Seuil.

Olivelle, Patrick (1993): The A'śrama System. The history and hermenteutics of a religious institution. New York - Oxford: Oxford University Press.

Olivelle, Patrick (1995): Rules and Regulations of Brahmanical Asceticism. Yatidharmasamuccaya of Yādava Prakāśa. Edited and translated. Albany: State University of New York Press.

Olivelle, Patrick (2000): Dharmasūtras. The Law Codes of Āpastamba, Gautama, Baudhāyana and Vasiștha. Annotated text and translation. Delhi: Motilal Banarsidass.

Olivelle, Patrick (2004): "The semantic history of dharma: the middle and late Vedic period." JIP 32, 491-511.

Olivelle, Patrick (2005): Manu's Code of Law. A critical edition and translation of the Mānava-Dharmaśāstra. Oxford University Press.

Olivelle, Patrick (ed.)(2006): Between the Empires. Society in India 300 BCE to 400 CE. Oxford University Press.

Olivelle, Patrick (tr.)(2008): Life of the Buddha by Aśvaghoṣa. New York University Press \& JJC Foundation.

Ostler, Nicholas (2005): Empires of the Word. A language history of the world. New York: HarperCollins.

Osto, Douglas (2008): Power, Wealth and Women in Indian Mahāyāna Buddhism: The Gandavyūha-sūtra. London \& New York: Routledge.

Pagel, Ulrich (2007): "Stūpa festivals in Buddhist narrative literature." Indica et Tibetica. Festschrift für Michael Hahn zum 65. Geburtstag von Freunden und Schülern überreicht. Ed. Konrad Klaus \& Jens-Uwe Hartmann. Wien: 
Arbeitskreis für Tibetische und Buddhistische Studien Universität Wien.

(Wiener Studien zur Tibetologie und Buddhismuskunde, 66.) Pp. 369-394.

Palaniappan, Sudalaimuthu (2008): "On the unintended influence of Jainism on the development of caste in post-classical Tamil society." International Journal of Jaina Studies (online) 4(2), 1-65.

Parasher, Aloka (1991): Mlecchas in Early India. A study in attitudes towards outsiders upto AD 600. New Delhi: Munshiram Manoharlal.

Parenti, Michael (2007): "Friendly Feudalism: The Tibet Myth." http://www.michaelparenti.org/Tibet.html\#notes

Pargiter, F. E. (1962): The Purāna Text of the Dynasties of the Kali Age. Second edition. Varanasi: The Chowkhamba Sanskrit Series Office.

Parpola, Asko (1988): "The coming of the Aryans to Iran and India and the cultural and ethnic identity of the Dāsas." Studia Orientalia 64, 195-302.

Parry, Jonathan P. (1994): Death in Banaras. Cambridge University Press.

Pāsādika, Bhikkhu (1996): "Universal responsibility according to Nāgārjuna's mDo kun las btus pa (Sūtrasamuccaya)." Universal Responsibility. A felicitation volume in honour of His Holiness the Fourteenth Dalai Lama, Tenzin Gyatso, on his sixtieth birthday. Ed. Ramesh Chandra Tewari \& Krishna Nath. New Delhi: A'N'B Publishers. Pp. 63-77.

Pāsādika, Bhikkhu (2001): "Grundvorstellungen zum Verhältnis zwischen Religion und weltlicher Macht im frühen Hīna- und Mahāyāna." Zwischen Säkularismus und Hierokratie. Ed. Peter Schalk. Uppsala. (Acta Universitatis Upsaliensis, Historia Religionum, 17.) Pp. 73-88.

Pāsādika, Bhikkhu (2006): “The development of Buddhist religion and literature in Cambodia and Vietnam." India's Interaction with Southeast Asia. Ed. G. C. Pande. New Delhi: Munshiram Manoharlal. (History of Science, Philosophy and Culture in Indian Civilization, I.3.) Pp. 463-488.

Pathak, Suniti Kumar (1974): The Indian Nìtiśāstras in Tibet. Delhi etc.: Motilal Banarsidass.

Pathak, S. K. (1997): "Nītiśāstra.” Glimpses of the Sanskrit Buddhist Literature (Vol. I). Ed. Kameshwar Nath Mishra. Sarnath, Varanasi: Central Institute of Higher Tibetan Studies. Pp. 74-87.

Pieruccini, Cinzia (2009): "Bharadvāja's hermitage and the paradise of the warrior (Rāmāyaṇa II 85." = Rossi \& Pieruccini, 2009: 25-41.

Pingree, David (1981): Jyotihśástra. Astral and mathematical literature. Wiesbaden: Otto Harrassowitz. (HIL vol. VI, fasc. 4.)

Pingree, David (2001): "Ravikās in Indian astronomy and the Kālacakra." Le Parole e i Marmi. Studi in onore di Raniero Gnoli nel suo $70^{\circ}$ compleanno. A cura di Raffaele Torella. Roma: Istituto Italiano per l'Africa e l'Oriente. 2001. (Serie Orientale Roma XCII, 2.) Pp. 655-664.

Plofker, Kim (2009): Mathematics in India. Princeton \& Oxford: Princeton University Press.

Pollock, Sheldon (1996): "The Sanskrit cosmopolis, 300-1300: Transculturation, vernacularization, and the question of ideology." Ideology and Status of Sanskrit. Contributions to the history of the Sanskrit language. Ed. Jan E. M. Houben. Leiden etc.: E. J. Brill. (Brill's Indological Library, 13.) Pp. 197-247.

Pollock, Sheldon (1998): “The cosmopolitan vernacular.” Journal of Asian 
Studies 57(1), 6-37.

Pollock, Sheldon (2001): "New intellectuals in seventeenth-century India." The Indian Economic and Social History Review 38(1), 3-31.

Pollock, Sheldon (2006): The Language of the Gods in the World of Men. Sanskrit, culture, and power in premodern India. Berkeley - Los Angeles London: University of California Press.

Pontillo, Tiziana (2009): "Where the ascetics lead their life of austerities, there peace and beauty are: what makes a place an āsrama in the Mahābhārata and in Kālidāsa's work." = Rossi \& Pieruccini, 2009: 43-57.

Prets, Ernst (2000): "Theories of debate, proof and counter-proof in the early Indian dialectical tradition." Studia Indologiczne 7 (On the Understanding of Other Cultures, ed. Piotr Balcerowicz \& Marek Mejor), 369-382.

Proferes, Theodore N. (2007): Vedic Ideals of Sovereignty and the Poetics of Power. New Haven, Connecticut: American Oriental Society. (American Oriental Series, 90.)

Quaritch Wales, H. G. (1931): Siamese State Ceremonies. Their history and function. London: Bernard Quaritch.

Quintanilla, Sonya Rhie (2000): “Āyāgapațas: characteristics, symbolism, and chronology." Artibus Asiae 60(1), 79-137.

Quintanilla, Sonya Rhie (2007): History of Early Stone Sculpture at Mathurā, ca. 150 BCE - 100 CE. Leiden - Boston: Brill. (Studies in Asian Art and Archaeology, 25.)

Qvarnström, Olle (2000): "Jain Tantra: divinatory and meditative practices in the twelfth-century Yogaśāstra of Hemacandra.” Tantra in Practice. Ed. David Gordon White. Princeton \& Oxford: Princeton University Press. Pp. 595604.

Qvarnström, Olle (tr.)(2002): The Yogaśāstra of Hemacandra. A twelfth century handbook on Śvetāmbara Jainism. Cambridge, Massachusetts \& London, England: Harvard University Press. (The title page erroneously spells the name of the author Quarnström)

Ramesh Chandra Babu, B. (2006): The Palaeography of Brāhmī Script in Āndhra (c. 300 B.C. - 300 A.D.). Delhi: Bharatiya Kala Prakashan.

Ranade, R. D. (1933): Mysticism in India: The poet-saints of Maharashtra. Poona. Reprint: State University of New York Press, Albany, 1983.

Rau, Wilhelm (1957): Staat und Gesellschaft im alten Indien nach den BrāhmanaTexten dargestellt. Wiesbaden: Otto Harrassowitz.

Ray, Himanshu Prabha (1986): Monastery and Guild. Commerce under the Sātavāhanas. Delhi etc.: Oxford University Press.

Ray, Himanshu Prabha (1989): "Early historical trade: an overview." The Indian Economic and Social History Review 26(4), 437-457.

Ray, Reginald A. (1994): Buddhist Saints in India. A study in Buddhist values and orientations. Oxford University Press.

Reischauer, Edwin O. (tr.)(1955): Ennin's Diary. The record of a pilgrimage to China in search of the Law. New York: Ronald Press.

Renondeau, G. \& Demiéville, Paul (1957): Histoire des moines guerriers du Japon par G. Renondeau; Le bouddhisme et la guerre par Paul Demiéville. Paris: Presses Universitaires de France. (Bibliothèque de l'Institut des Hautes Études Chinoises, 11.) 
Renou, L. (1942): Review of Philologica Indica by Heinrich Lüders. OLZ 45, 187-191.

Reynolds, Frank E. (1976): "The many lives of Buddha: A study of sacred biography and Theravāda tradition." The Biographical Process: Studies in the History and Psychology of Religion. Ed. Frank E. Reynolds \& Donald Capps. The Hague - Paris: Mouton. Pp. 37-61.

Rhys Davids, T. W. (tr.)(1878): Buddhist Birth-stories (Jataka Tales): The Commentarial Introduction Entitled Nidāna-kathā, the story of the lineage. Reprint: Indological Book House, Varanasi - Delhi, 1973.

Rhys Davids, T. W. (tr.)(1890): The Questions of King Milinda. Oxford University Press. Reprint: Motilal Banarsidass, Delhi, 1965.

Ritschl, Eva (1980): “Brahmanische Bauern.” Altorientalische Forschungen 7, 177-187.

Robinson, James B. (tr.)(1979): Buddha's Lions. The Lives of the Eighty-Four Siddhas. Caturaśîti-siddha-pravrtti by Abhayadatta. Berkeley: Dharma Publishing.

Rossi, Paola M. \& Pieruccini, Cinzia (ed.(2009): Kings and Ascetics in Indian Classical Literature. Milano: Cisalpino, Istituto Editoriale Universitario. (Università degli Studi di Milano, Facoltà di lettere e filosofia, Quaderni de Acme, 112.)

Roth, Gustav (1980): "Symbolism of the Buddhist stūpa according to the Tibetan version of the Caitya-vibhāga-vinayodbhāva-sūtra, the Sanskrit treatise Stūpa-lakṣana-kārikā-vivecana, and a corresponding passage in Kuladatta's Kriyāsamgraha." = Dallapiccola, 1980: 183-209.

Ruegg, D. Seyfort (1986): Review of Sanskrit-Wörterbuch der buddhistischen Texte aus den Turfan-Funden, 3. JAOS 106, 596-597.

Ruegg, David Seyfort (1995): Ordre spirituel et ordre temporel dans la pensée bouddhique de l'Inde et du Tibet. Quatre conférences au Collège de France. Paris: Collège de France. (Publications de l'Institut de Civilisation Indienne, 64.)

Ruegg, David Seyfort (2008): The Symbiosis of Buddhism with Brahmanism/Hinduism in South Asia and of Buddhism with 'Local Cults' in Tibet and the Himalayan Region. Wien: ÖAW. (SAWW 774; Beiträge zur Kultur- und Geistesgeschichte Asiens 58.)

Ryan, Bryce (1953): Caste in Modern Ceylon : The Sinhalese system in transition. New Brunswick, N. J.: Rutgers University Press.

Sachau, Edward C. (1888): Alberuni's India. An account of the religion, philosophy, literature, geography, chronology, astronomy, customs, laws and astrology of India about A. D. 1013. London: Routledge and Kegan Paul. Reprint: S Chand \& Co., New Delhi.

Saddanīti. La grammaire palie d'Aggavamsa. Texte établi par Helmer Smith. 6 vols. Lund: C.W.K. Gleerup. 1928-1966.

Sahgal, Smita (1994): "Spread of Jinism in North India between circa 200 B.C. and circa A.D. 300." Jainism and Prakrit in Ancient and Medieval India. Essays for Prof. Jagdish Chandra Jain. Ed. N. N. Bhattacharyya. New Delhi: Manohar. Pp. 205-232. 
Saito, Shigeru (2010): "The Gandhāran disturbance in the late $4^{\text {th }}$ century as a context: a new viewpoint of Gandhāran Buddhism." Indian Philosophy and Text Science. Ed. Toshihiro Wada. Delhi: Motilal Banarsidass. Pp. 59-73.

Salomon, Richard (1998): Indian Epigraphy. A guide to the study of inscriptions in Sanskrit, Prakrit, and the other Indo-Aryan languages. New York Oxford: Oxford University Press.

Salomon, Richard (1999): Ancient Buddhist Scrolls from Gandhāra. The British Library Kharoșthī fragments. Washington: University of Washington Press; London: British Library.

Salomon, Richard (2001): “'Gāndhārī hybrid Sanskrit': New sources for the study of the Sanskritization of Buddhist literature." IIJ 44, 241-252.

Salomon, Richard (2005): "The Indo-Greek era of 186/5 BC in a Buddhist reliquary inscription." Afghanistan: ancien carrefour entre l'est et l'ouest. Ed. Osmund Bopearachchi \& Marie-Françoise Boussac. Turnhout: Brepols. Pp. 359-401.

Salomon, Richard (2006): "Recent discoveries of early Buddhist manuscripts and their implications for the history of Buddhist texts and canons." = Olivelle, 2006: 349-382.

Salomon, Richard (2009): "The fine art of forgery in India." Écrire et transmettre en Inde classique. Ed. Gérard Colas \& Gerdi Gerschheimer. Paris: École française d'Extrême-Orient. (Études thématiques, 23.) Pp. 107-134.

Salomon, Richard (2009a): “Aśoka and the 'epigraphic habit' in India." Aśoka in History and Historical Memory. Ed. Patrick Olivelle. Delhi: Motilal Banarsidass. Pp. 45-52.

Samavāya Añga. In: Anga Suttāni I. Āyāro - Sūyagaḍo - Ṭhānạ̣ - Samavāo. Edited by Muni Nathamal. Ladnun (Rajasthan): Jain Viswa Bhārati. V. S. 2031. Pp. 827 ff.

Samuel, Geoffrey (1993): Civilized Shamans. Buddhism in Tibetan Society. Washington \& London: Smithsonian Institution Press.

Samuel, Geoffrey (2002): "Buddhism and the state in eighth century Tibet." Religion and Secular Culture in Tibet. Ed. Henk Blazer. Leiden etc.: Brill. (Brill's Tibetan Studies Library, 2/2.) Pp. 1-19. Reprint: Samuel, 2005: 94115.

Samuel, Geoffrey (2008): The Origins of Yoga and Tantra. Indic religions to the thirteenth century. Cambridge University Press.

Sanderson, Alexis (1988): "Śaivism and the Tantric traditions." The World's Religions. Ed. Stewart Sutherland, Leslie Houlden, Peter Clarke \& Friedhelm Hardy. London: Routledge. Pp. 660-704.

Sanderson, Alexis (1994): "Vajrayāna: origin and function." Buddhism into the Year 2000. International Conference Proceedings. Bangkok - Los Angeles: Dhammakaya Foundation. Pp. 87-102.

Sanderson, Alexis (1995): "Meaning in Tantric ritual." Essais sur le rituel III. Ed. Anne-Marie Blondeau \& Kristofer Schipper. Louvain - Paris: Peeters. (Biblithèque de l'École des Hautes Études, Section des sciences religieuses, 102.) Pp. 15-95.

Sanderson, Alexis (2004): “The Śaiva religion among the Khmers, part I." BEFEO 90/91 (2003-04), 349-462.

Sanderson, Alexis (2005): "Religion and the state: Śaiva officiants in the territory 
of the king's Brahmanical chaplain.” IIJ 47 (2004), 229-300.

Sanderson, Alexis (2007): "Atharvavedins in Tantric territory. The Āंngirasakalpa texts of the Oriya Paippalādins and their connection with the Trika and the Kālīkula. With critical editions of the Parājapavidhi, the Parāmantravidhi, and the Bhadrakālīmantravidhiprakarana." The Atharvaveda and its Paippalādaśākhā. Historical and philological papers on a Vedic tradition. Ed. Arlo Griffiths \& Annette Schmiedchen. Aachen: Shaker Verlag. (Geisteskultur Indiens. Texte und Studien, 11.) Pp. 195-311.

Sanderson, Alexis (2007a): "The Śaiva exegesis of Kashmir." Mélanges tantriques à la mémoire d'Hélène Brunner / Tantric Studies in Memory of Hélène Brunner. Ed. Dominic Goodall \& André Padoux. Institut Français de Pondichéry / École Française d'Extrême-Orient. (Collection Indologie, 106.) Pp. 231-442.

Sanderson, Alexis (2009): "The Śaiva Age: the rise and dominance of Śaivism during the early medieval period." Genesis and Development of Tantrism. Ed. Shingo Einoo. Tokyo: Institute of Oriental Culture, University of Tokyo. Pp. 41-349.

Sastri, Hiranand (1942): Nalanda and its Epigraphical Material. Reprint: Sri Satguru Publications, Delhi, 1986. (Asian Arts and Archaeology Series, 3.)

Schalk, Peter (ed.)(2002): Buddhism among Tamils in Pre-Colonial Tamilakam and Ilam. Part 1: Prologue. The Pre-Pallava and the Pallava Period. Uppsala: Uppsala Universitet.

Scharfe, Hartmut (1968): Untersuchungen zur Staatsrechtslehre des Kautalya. Wiesbaden: Otto Harrassowitz.

Scharfe, Hartmut (1977): Grammatical Literature. Wiesbaden: Otto Harrassowitz. (A History of Indian Literature, Vol. V, Fasc. 2.)

Scharfe, Hartmut (1989): The State in Indian Tradition. Leiden etc.: E. J. Brill. (Handbuch der Orientalistik 2/3/2.)

Scharfe, Hartmut (1993): Investigations in Kautalya's Manual of Political Science. Second, revised edition of Scharfe, 1968.

Scharfe, Hartmut (2002): Education in Ancient India. Leiden etc.: Brill. (Handbook of Oriental Studies, Sect. II: India, 16.)

Scherrer-Schaub, Cristina (2003): "Un traité de politique du bouddhisme indien: Lecture de la Ratnāvalī de Nāgārjuna (IIe-IIIe siècles de notre ère) [suite et fin]." Annuaire de l'École pratique des hautes études 111 (2002-2003), 131-136.

Scherrer-Schaub, Cristina (2007): "Immortality extolled with reason: Philosophy and politics in Nāgārjuna." Pramānakīrtih. Papers dedicated to Ernst Steinkellner on the occasion of his $70^{\text {th }}$ birthday. Ed. Birgit Kellner, Helmut Krasser, Horst Lasic, Michael Torsten Much \& Helmut Tauscher. Part 2. Wien: Arbeitskreis für Tibetische und Buddhistische Studien Universität Wien. Pp. 757-793.

Schlingloff, Dieter (1964/2006): Ein buddhistisches Yogalehrbuch. Unveränderter Nachdruck der Ausgabe von 1964 unter Beigabe aller seither bekannt gewordenen Fragmente. Herausgegeben von Jens-Uwe Hartmann und Hermann-Josef Röllicke. Düsseldorf: Haus der Japanischen Kultur (EK $\div)$. (Buddhismus-Studien / Buddhist Studies 5 / 2006.) 
Schlingloff, Dieter (1969): Die altindische Stadt. Eine vergleichende

Untersuchung. Mainz: Akademie der Wissenschaften und der Literatur /

Wiesbaden: Franz Steiner. (Akademie der Wissenschaften und der

Literatur; Abhandlungen der Geistes- und Sozialwissenschaftlichen

Klasse, Jahrgang 1969, Nr. 5.)

Schlingloff, Dieter (2006): "Das Schema der Stadt in den narrativen

Ajantamalereien.” Vanamālā. Festschrift A. J. Gail. Ed. Gerd J. R.

Mevissen \& Klaus Bruhn. Berlin: Weidler. Pp. 214-218.

Schmithausen, Lambert (1996): "Buddhismus und Glaubenskriege."

Glaubenskriege in Vergangenheit und Gegenwart. Ed. Peter Herrmann.

Göttingen: Vandenhoeck \& Ruprecht. Pp. 63-92.

Schmithausen, Lambert (1999): "Aspects of the Buddhist attitude towards war."

Violence Denied: Violence, Non-Violence and the Rationalization of

Violence in South Asian Cultural History. Ed. Jan E. M. Houben \& Karel

R. van Kooij. Leiden etc.: Brill. (Brill's Indological Library, 16.) Pp. 45-

67.

Schmithausen, Lambert (2003): "Einige besondere Aspekte der 'Bodhisattva-

Ethik' in Indien und ihre Hintergründe." Hōrin 10, 21-46.

Schmithausen, Lambert (2007): “Zur Frage, ob ein Bodhisattva unter bestimmten

Voraussetzungen in einer neutralen Geisteshaltung (avyākrta-citta) töten

darf." Indica et Tibetica. Festschrift für Michael Hahn. Zum 65.

Geburtstag von Freunden und Schülern überreicht. Ed. Konrad Klaus \&

Jens-Uwe Hartmann. Wien: Arbeitskreis für Tibetische und Buddhistische

Studien Universität Wien. (Wiener Studien zur Tibetologie und

Buddhismuskunde, 66.) Pp. 423-440.

Schneider, Johannes (1993): Der Lobpreis der Vorzüglichkeit des Buddha.

Udbhațasvāmins Viśeșastava mit Prajñāvarmans Kommentar. Nach dem

tibetischen Tanjur herausgegeben und übersetzt. Bonn: Indica et Tibetica.

(Indica et Tibetica, 23.)

Schneider, Johannes (1995): "Der Buddha als der wahre Śiva:

Udbhatasiddhasvāmins Sarvajñamaheśvarastotra." Berliner Indologische

Studien 8, 153-187.

Schneider, Ulrich (1978): Die grossen Felsen-Edikte Aśokas. Kritische Ausgabe, Übersetzung und Analyse der Texte. Wiesbaden: Otto Harrassowitz.

(Freiburger Beiträge zur Indologie, 11.)

Scholem, Gershom (1957): Die jüdische Mystik in ihren Hauptströmungen. Suhrkamp Taschenbuch. 1980.

Schopen, Gregory (1975): “The phrase 'sa prthivīpradeśaś caityabhūto bhavet' in the Vajracchedikā : Notes on the cult of the book in Mahāyāna.” IIJ 17, 147-181. Reprint with stylistic changes: Schopen, 2005: 25-62.

Schopen, Gregory (1985): "Two problems in the history of Indian Buddhism : the layman/monk distinction and the doctrines of the transference of merit." (StII 10, 9-47.) Reprint with stylistic changes: Schopen, 1997: 23-55.

Schopen, Gregory (1987): "Burial ad sanctos and the physical presence of the Buddha in early Indian Buddhism: a study in the archaeology of religions." (Religion 17, 193-225.) Reprint with stylistic changes:

Schopen, 1997: 114-147. 
Schopen, Gregory (1988-89): “On monks, nuns and 'vulgar' practices: the introduction of the image cult into Indian Buddhism." (Artibus Asiae 49(1/2), 153-168.) Reprint with stylistic changes: Schopen, 1997: 238-257.

Schopen, Gregory (1990): "The Buddha as an owner of property and permanent resident in medieval Indian monasteries." (JIP 18, 181-217.) Reprint with stylistic changes: Schopen, 1997: 258-289.

Schopen, Gregory (1991): "Monks and the relic cult in the Mahāparinibbānasutta. An old misunderstanding in regard to monastic Buddhism." From Benares to Beijing: Essays on Buddhism and Chinese religion. Ed. Koichi Shinohara \& Gregory Schopen. Oakville, Ontario: Mosaic Press. Pp. 187201. Reprint with stylistic changes: Schopen, 1997: 99-113.

Schopen, Gregory (1992): "On avoiding ghosts and social censure. Monastic funerals in the Mūlasarvāstivāda-vinaya." (JIP 20, 1-39.) Reprint with stylistic changes: Schopen, 1997: 204-237.

Schopen, Gregory (1992a): "The ritual obligations and donor roles of monks in the Pāli Vinaya.” (JPTS 16, 87-107.) Reprint with stylistic changes: Schopen, 1997: 72-85.

Schopen, Gregory (1995): "Deaths, funerals, and the division of property in a monastic code." Buddhism in Practice. Ed. Donald S. Lopez. Delhi: Munshiram Manoharlal. Pp. 473-502. Reprint with stylistic changes: Schopen, 2004: 91-121.

Schopen, Gregory (1996): "The suppression of nuns and the ritual murder of their special dead in two Buddhist monastic texts." JIP 24, 563-592. Reprint with stylistic changes: Schopen, 2004: 329-359.

Schopen, Gregory (1997): Bones, Stones, and Buddhist Monks. Collected papers on the archaeology, epigraphy, and texts of monastic Buddhism in India. Honolulu: University of Hawai'i Press.

Schopen, Gregory (1997a): "If you can't remember, how to make it up: Some monastic rules for redacting canonical texts." Bauddhavidyāsudhākarah. Studies in Honour of Heinz Bechert on the Occasion of His $65^{\text {th }}$ Birthday. Ed. Petra Kieffer-Pülz \& Jens-Uwe Hartmann. Swisttal-Odendorf. (Indica et Tibetica, 30.) Pp. 571-582. Reprint with stylistic changes: Schopen, 2004: 395-407.

Schopen, Gregory (1998): "Marking time in Buddhist monasteries. On calendars, clocks, and some liturgical practices." Sūryacandrāya: Essays in Honour of Akira Yuyama on the Occasion of his 65th Birthday. Ed. Paul Harrison and Gregory Schopen. Swisttal-Odendorf: Indica et Tibetica Verlag. Pp. 157-179. Reprint with stylistic changes: Schopen, 2004: 260-284.

Schopen, Gregory (2004): Buddhist Monks and Business Matters. Still more papers on monastic Buddhism in India. Honolulu: University of Hawai'i Press.

Schopen, Gregory (2005): Figments and Fragments of Mahāyāna Buddhism in India. More collected papers. Honolulu: University of Hawai'i Press.

Schopen, Gregory (2006): "A well-sanitized shroud. Asceticism and institutional values in the Middle Period of Buddhist monasticism." = Olivelle, 2006: 315-347.

Schopen, Gregory (2006a): “The Buddhist 'monastery' and the Indian garden: aesthetics, assimilations, and the siting of monastic establishments." JAOS 
126(4), 487-505.

Schopen, Gregory (2006b): "On monks and menial laborers: Some monastic accounts of building Buddhist monasteries." Architetti, Capomastri, Artigiani. L'organizzazione dei canieri e della produzione artistica nell'Asia ellenistica. Studi offerti a Domenico Faccenna nel suo ottantesimo compleanno. Ed. Pierfrancesco Callieri. Roma: Istituto Italiano per l'Africa e 1'Oriente. (Serie Orientale Roma, C.) Pp. 225-245.

Schopen, Gregory (2007): "Cross-dressing with the dead: asceticism, ambivalence, and institutional values in an Indian monastic code." The Buddhist Dead. Practices, Discourses, Representations. Ed. Bryan J. Cuevas \& Jacqueline I. Stone. Honolulu: University of Hawai'i Press. (Studies in East Asian Buddhism, 20.) Pp. 60-104.

Schopen, Gregory (2009): "On the absence of Urtexts and otiose ācāryas: buildings, books, and lay buddhist ritual at Gilgit." Écrire et transmettre en Inde classique. Ed. Gérard Colas \& Gerdi Gerschheimer. Paris: École française d'Extrême-Orient. (Études thématiques, 23.) Pp. 189-219.

Schopen, Gregory (2009a): "The urban Buddhist nun and a protective rite for children in early North India." Pāsādikadānaṃ. Festschrift für Bhikkhu Pāsādika. Ed. Martin Straube, Roland Steiner, Jayandra Soni, Michael Hahn \& Mitsuyo Demoto. Marburg: Indica et Tibetica Verlag. (Indica et Tibetica, 52.) Pp. 359-380.

Schubring, Walther (2000): The Doctrine of the Jainas Described after the Old Sources. Translated from the revised German edition by Wolfgang Beurlen. With three indices enlarged and added by Willem Bollée and Jayandra Soni. Delhi: Motilal Banarsidass. (Lala Sundarlal Jain Research Series, 15.)

Sen, Amartya (2005): The Argumentative Indian. Writings on Indian history, culture and identity. London etc.: Penguin Books.

Sen, Chitrabhanu (1978): A Dictionary of Vedic Rituals, based on the Śrauta and Gṛya Sūtras. Delhi: Concept Publishing.

Senart, Émile (1900): "Bouddhisme et Yoga." RHR 43(2), 345-364.

Senart, E. (1906): "The inscriptions in the caves at Nāsik." EpInd 8 (1905-1906), 59-96.

Seneviratne, H. L. (1963): “The Äsala Perahära in Kandy.” Ceylon Journal of Historical and Social Studies 6, 169-180.

Seneviratne, H. L. (1978): Rituals of the Kandyan State. Cambridge: Cambridge University Press.

Shah, Priyabala (1952): “Aiḍuka.” JOIB 1(3), 278-285.

Sharf, Robert H. (1992): "The idolization of enlightenment : on the mummification of Ch'an masters in medieval China." History of Religions 32(1), 1-31.

Sharma, V. K. (2001): History of Jainism, with special reference to Mathurā. New Delhi: D. K. Printworld. (Reconstructing Indian History \& Culture, 23.)

Shee, Monika (1986): Tapas und tapasvin in den erzählenden Partien des Mahābhārata. Reinbek: Inge Wezler. (Studien zur Indologie und Iranistik, Dissertationen Band 1.)

Shen, Weirong (2004): "Magic power, sorcery and evil spirit: the image of Tibetan monks in Chinese literature during the Yuan dynasty." The 
Relationship Between Religion and State (chos srid zung 'brel) In Traditional Tibet. Ed. Christoph Cüppers. Lumbini: Lumbini International Research Institute. Pp. 189-227.

Silk, Jonathan A. (1997): "Further remarks on the yogācāra bhikșu."

Dharmadhüta: Mélanges offerts au Vénérable Thích Huyên-Vi à l'occasion de son soixante-dixième anniversaire. Ed. Bhikkhu Pāsādika \& Bhikkhu Tampalawela Dhammaratana. Paris: Éditions You Feng. Pp. 233-250.

Silk, Jonathan A. (2000): "The yogācāra bhikṣu." Wisdom, Compassion, and the Search for Understanding. The Buddhist Studies Legacy of Gadjin M. Nagao. Ed. Johathan A. Silk. Honolulu: University of Hawai'i Press. Pp. 265-314.

Silk, Jonathan A. (2006): Body Language. Indic śarìra and Chinese shèlì in the Mahāparinirvāna-sūtra and Saddharmapuṇdarīka. Tokyo: The International Institute for Buddhist Studies. (Studia Philologica Buddhica, Monograph Series, 19.)

Simpson, William (1888): "Some suggestions of origin in Indian architecture." JRAS, New Series 20(4), 49-71.

Sircar, D. C. (1951): “The Sātavāhanas and the Chedis.” = Majumdar, 1951: 191216.

Sircar, Dines Chandra (1965): Select Inscriptions bearing on Indian History and Civilization. Volume I: From the sixth century B.C. to the sixth century A.D. University of Calcutta.

Sircar, Dines Chandra (1983): Select Inscriptions bearing on Indian History and Civilization. Volume II: From the sixth to the eighteenth century A.D. Delhi etc.: Motilal Banarsidass.

Skilling, Peter (1997): Mahāsūtras: Great Discourses of the Buddha. Volume II, Parts I \& II. Oxford: The Pali Text Society.

Skilling, Peter (2005): "Cutting across categories: the ideology of relics in Buddhism." Annual Report of The International Research Institute for Advanced Buddhology at Soka University for the Academic Year 2004. Tokyo: Soka University. Pp. 269-310.

Skilling, Peter (2007): "King, sangha and brahmans: Ideology, ritual and power in pre-modern Siam." Buddhism, Power and Political Order. Ed. Ian Harris. London \& New York: Routledge. Pp. 182-215.

Skilling, Peter (2007a): "Zombies and half-zombies: Mahāsūtras and other protective measures." JPTS 29 (Festschrift in honour of the $80^{\text {th }}$ birthday of K. R. Norman in 2005 and the $125^{\text {th }}$ anniversary in 2006 of the founding of the Pali Text Society; ed. O. von Hinüber, R. M. L. Gethin and Mark Allon), 313-330.

Skilling, Peter (2008): "Dharma, Dhāran̄i, Abhidharma, Avadāna: What was taught in Trayastrimśa?" Annual Report of The International Research Institute for Advanced Buddhology at Soka University for the Academic Year 2007, pp. 37-60.

Skilling, Peter (2009): Buddhism and Buddhist Literature of South-East Asia:

Selected Papers. Edited by Claudio Cicuzza. Bangkok and Lumbini:

Fragile Palm Leaves Foundation / Lumbini International Research Institute. 2009. (Materials for the Study of the Tripitaka, 5.)

Skorupski, Tadeusz (ed., tr.)(1983): The Sarvadurgatipariśodhana Tantra: 
Elimination of All Evil Destinies. Sanskrit and Tibetan texts with introduction, English translation and notes. Delhi etc.: Motilal Banarsidass.

Ślaczka, Anna A. (2007): Temple Consecraton Rituals in Ancient India. Text and archaeology. Leiden - Boston: Brill. (Brill's

Smith, Vincent A. (1900): The Jain stūpa and other Antiquities of Mathurā. Allahabad. (Archaeological Survey of India: New Imperial Series Vol. 20; North-Western Provinces and Oudh. Vol. 5. Muttra Antiquities.) Reprint: Indological Book House, Varanasi - Delhi, 1969.

Smith, Vincent A. (1958): The Oxford History of India. Third edition edited by Percival Spear. Oxford: Clarendon Press.

Snellgrove, David L. (1987): Indo-Tibetan Buddhism. Indian Buddhists and their Tibetan successors. London: Serindia Publications.

Snellgrove, David (2001): "The relationship of Buddhism to the royal Brahmanical cult in the Khmer empire." Le Parole e i Marmi. Studi in onore di Raniero Gnoli nel suo $70^{\circ}$ compleanno. Ed. Raffaele Torella. Roma: Istituto Italiano per l'Africa e 1'Oriente. (Serie Orientale Roma XCII,2.) Pp. 797-833.

Solomon, Esther A. (1976-1978): Indian dialectics. Methods of philosophical discussion. 2 vols. Ahmedabad: Gujarat Vidya sabha. (Research series, Sheth Bholabhai Jeshingbhai Institute of Learning and Research, 70 \& 74.)

Spellman, John W. (1964): Political Theory of Ancient India. A study of kingship from the earliest times to circa A.D. 300. Oxford: Clarendon Press.

Srinivasan, Doris Meth (ed.)(1989): Mathurā: the cultural heritage. New Delhi: American Institute of Indian Studies.

Staal, Frits (2008): Discovering the Vedas. Origins, mantras, rituals, insights. New Delhi: Penguin Books India.

Stahl, William Harris; Johnson, Richard; with Burge, E. L. (tr.)(1977): Martianus Capella and the Seven Liberal Arts. Volume II: The marriage of philology and mercury. New York: Columbia University Press.

Staviskij, B. Ja. (1986): La Bactriane sous les Kushans : Problèmes d'histoire et de culture. Édition revue et augmentée. Traduite du russe par P. Bernard, M. Burda, F. Grenet, P. Leriche. Paris: Librairie d'Amérique et d'Orient, Jean Maisonneuve.

Stein, Burton (1980): Peasant State and Society in Medieval South India. Delhi etc.: Oxford University Press.

Stein, M. A. (ed.)(1892): Kalhana's Rājataraingin̄i or Chronicle of the Kings of Kashmir. Vol. I: Sanskrit text with critical notes. Reprint: Munshi Ram Manohar Lal, Delhi, 1960.

Sternagel, Peter (1966): Die Artes Mechanicae im Mittelalter. Begriffs- und Bedeutungsgeschichte bis zum Ende des 13. Jahrhunderts. Kallmünz: Michael Lassleben. (Münchener historische Studien, Abteilung mittelalterliche Geschichte, Bd. 2.)

Stietencron, Heinrich von (1995): "Die mythischen Dimension von Kampf und Krieg.” Töten im Krieg. Ed. Heinrich von Stietencron \& Jörg Rüpke. Freiburg - München: Karl Alber. (Veröffentlichungen des "Instituts für historische Anthropologie E. V.”, 6.) 
Strickmann, Michel (1996): Mantras et mandarins. Le bouddhisme tantrique en Chine. Gallimard.

Strong, John S. (1983): The Legend of King Aśoka. A study and translation of the Aśokāvadāna. Princeton, New Jersey: Princeton University Press.

Strong, John S. (1992): The Legend and Cult of Upagupta. Sanskrit Buddhism in North India and Southeast Asia. Princeton, New Jersey: Princeton University Press.

Strong, John S. (2004): Relics of the Buddha. Princeton University Press.

Strong, John S. (2004a): "Buddhist relics in comparative perspective : beyond the parallels." = Germano \& Trainor, 2004: 27-49.

Strong, John S. (2007): “Two Buddha relic traditions." Religion Compass 1(3), 341-352.

Strong, John S. (2007a): “The Buddha's funeral." The Buddhist Dead. Practices, Discourses, Representations. Ed. Bryan J. Cuevas \& Jacqueline I. Stone. Honolulu: University of Hawai'i Press. (Studies in East Asian Buddhism, 20.) Pp. 32-59.

Strong, John S. \& Strong, Sarah M. (1995): "A tooth relic of the Buddha in Japan : an essay on the Sennyū-ji tradition and a translation of Zeami's Nō play 'Shari'.' Japanese Religions 20, 1-33.

Takakusu, J. (tr.)(1896): A Record of the Buddhist Religion and practised in India and the Malay Archipalago (A.D. 671-695). Reprint: Munshiram Manoharlal, Delhi, 1966.

Takakusu, J. (1904): "The Life of Vasu-bandhu, by Paramārtha (A.D. 499-569)." T'oung Pao, Série II, Vol. V, pp. 269-296 \& 620.

Tambiah, Stanley Jeyaraja (1984): The Buddhist Saints of the Forest and the Cult of Amulets. Cambridge: Cambridge University Press. (Cambridge Studies in Social Anthropology, 49.)

Thakur, Vijay Kumar (1981): Urbanisation in Ancient India. Delhi: Abhinav.

Thapar, Romila (1963): Aśoka and the Decline of the Mauryas. Delhi etc.: Oxford University Press.

Thapar, Romila (2002): The Penguin History of Early India, from the origins to $A D$ 1300. London: Penguin Books.

Thapar, Romila (2005): "Creating traditions through narration. The case of Śakuntalā." Boundaries, Dynamics and Construction of Traditions in South Asia. Ed. Federico Squarcini. Firenze University Press / Munshiram Manoharlal. Pp. 159-173.

Thaplyal, Kiran Kumar (2004): Village and Village Life in Ancient India. A study of village and village life in northern India from 6th century $B C$ to 1 st century AD. New Delhi: Aryan Books International.

Thapliyal, Uma Prasad (1979): Foreign Elements in Ancient Indian Society. New Delhi: Munshiram Manoharlal.

Tiefenauer, Marc (2001): Les enfers purāniques d'après des morceaux choisis. Unpublished "mémoire de licence". Lausanne: Université de Lausanne.

Tieken, H. (1992): "Style and structure of Rājaśekhara's Kāvyamīmāmsā with special reference to chapter X on the relation between king and poet." Ritual, State and History in South Asia. Essays in Honour of J. C. Heesterman. Ed. A. W. van den Hoek, D. H. A. Kolff, M. S. Oort. Leiden etc.: E. J. Brill. Pp. 366-374. 
Tillemans, Tom J. F. (1990): Materials for the Study of Āryadeva, Dharmapāla and Candrakìrti. The Catuhśataka of Āryadeva, chapters XII and XIII, with the commentaries of Dharmapāla and Candrakīrti: Introduction, translation, Sanskrit, Tibetan and Chinese texts, notes. 2 vols. Wien: Arbeitskreis für Tibetische und Buddhistische Studien, Universität Wien. (Wiener Studien zur Tibetologie und Buddhismuskunde 24, 1-2.)

Trainor, Kevin (1997): Relics, Ritual, and Representation in Buddhism. Rematerializing the Sri Lankan Theravāda tradition. Cambridge: Cambridge University Press. (Cambridge Studies in Religious Traditions, 10.)

Trautmann, Thomas R. (1971): Kauțilya and the Arthaśāstra. A statistical investigation of the authorship and evolution of the text. Leiden: E. J. Brill.

Trimondi, Victor \& Victoria (1999): Der Schatten des Dalai Lama. Sexualität, Magie und Politik im tibetischen Buddhismus. Düsseldorf: Patmos Verlag.

Tripathi, Dipti S. (1986): "Apabhramśa in Sanskrit grammar: an appraisal of Bhartrhari's view." Aligarh Journal of Oriental Studies 3(2), 81-92.

Tsuchida, Ryūtarō (1991): "Two categories of Brahmins in the early Buddhist period." Memoirs of the Research Department of the Toyo Bunko 49, 5195.

Tsuchida, Ryutaro (2009): "Some reflections on the chronological problems of the Mahābhārata." Studies in Indian Philosophy and Buddhism 16, 1-24.

Udayana: Ātmatattvaviveka. Ātmatattvaviveka by Udayanācārya, with Translation, Explanation and Analytical-Critical Survey, by N. S. Dravid. Shimla: Indian Institute of Advanced Study, Rashtrapati Nivas. 1995.

van Buitenen, J. A. B. (tr.)(1973, 1975, 1978): The Mahābhārata. 3 volumes, covering 5 books, have appeared. The University of Chicago Press.

van Kooij, Karel R. (1990): "Display of the relics in early Buddhist art." Ancient Ceylon: Journal of the Archaeological Survey Department of Sri Lanka 7, volume 1 (Papers submitted to the International Seminar - Towards the Second Century of Archaeology in Sri Lanka on 7th-13th July 1990 Colombo), pp. 125-146.

van Leur, Jacob Cornelis (1955): Indonesian Trade and Society. Essays in Asian social and economic history. The Hague. Reprint: Foris Publication Holland, Dordrecht / U.S.A., Cinnaminson, 1983.

van Naerssen, F. H. \& de Iongh, R. C. (1977): The Economic and Administrative History of Early Indonesia. Leiden/Köln: E. J. Brill. (Handbuch der Orientalistik 3.7.)

Verardi, Giovanni (1996): "Religions, rituals, and the heaviness of Indian history." Annali 56, 215-253.

Vergati, Anne (1994): "Bouddhisme et caste dans la vallée de Kathmandu." Bouddhisme et cultures locales. Quelques cas de réciproques adaptations. Ed. Fukui, Fumimasa \& Fussman, Gérard. Paris: École française d'Extrême-Orient. (Études thématiques, 2.) Pp. 53-68.

Verhagen, Pieter C. (1999): "Expressions of violence in Buddhist Tantric mantras." Violence Denied: Violence, Non-Violence and the Rationalization of Violence in South Asian Cultural History. Ed. Jan E. M. Houben \& Karel R. van Kooij. Leiden etc.: Brill. (Brill's Indological Library, 16.) Pp. 275-285. 
Virkus, Fred (2004): Politische Strukturen im Guptareich (300-550 n. Chr.).

Wiesbaden: Harrassowitz. (Asien- und Afrika-Studien der HumboldtUniversität zu Berlin, 18.)

Vogel, J. Ph. (1918): "The Yūpa inscriptions of King Mūlavarman, from Koetei (East Borneo)." Bijdragen tot de Taal-, Land-en Volkenkunde 79, 167232.

Wagle, Narendra (1966): Society at the Time of the Buddha. Bombay: Popular Prakashan.

Wagner, Andreas (ed.)(2006): Primäre und sekundäre Religion als Kategorie der Religionsgeschichte des Alten Testaments. Berlin - New York: Walter de Gruyter. (Beihefte zur Zeitschrift für die alttestamentliche Wissenschaft, 364.)

Waldschmidt, Ernst (1944-1948): Die Überlieferung vom Lebensende des Buddha. Eine vergleichende Analyse des Mahāparinirvānasūtra und seiner Textentsprechungen. Göttingen: Vandenhoeck \& Ruprecht. (Abhandlungen der Akademie der Wissenschaften in Göttingen, philologisch-historische Klasse, Dritte Folge, Nr. 29-30.)

Waldschmidt, Ernst (1950-1951): Das Mahāparinirvānasūtra. Text in Sanskrit und Tibetisch, verglichen mit dem Pāli nebst einer Übersetzung der chinesischen Entsprechung im Vinaya der Mūlasarvāstivādins. Auf Grund von Turfan-Handschriften herausgegeben und bearbeitet. 3 vols. Berlin: Akademie-Verlag. (Abhandlungen der Deutschen Akademie der Wissenschaften zu Berlin, Philosophisch-historische Klasse, Jahrgang 1949 Nr. 1, Jahrgang 1950 Nr. 2 \& 3.) Reprint in one volume: Rinsen Book Co., Kyoto 1986.

Wallace, Vesna A. (2010): Review of Divine Knowledge: Buddhist Mathematics According to the Anonymous Manual of Mongolian Astrology and Divination by Brian Baumann (Brill, Leiden 2008), Journal of Asian Studies 69(1), 244-245.

Walser, Joseph (2002): "Nāgārjuna and the Ratnāvalī: new ways to date an old philosopher.” JIABS 25(1-2), 209-262.

Walser, Joseph (2009): “The origin of the term 'Mahāyāna' (the great vehicle) and its relationship to the Āgamas." JIABS 30(1-2), 2007 [2009], 219-250.

Walshe, Maurice (1987): The Long Discourses of the Buddha. A translation of the Dīgha Nikāya. Boston: Wisdom Publications. 1995.

Walter, Michael L. (2009): Buddhism and Empire. The political and religious culture of early Tibet. Leiden - Boston: Brill. (Brill's Tibetan Studies Library, 22.)

Walters, Jonathan S. (1997): "Stūpa, story and empire: Constructions of the Buddha biography in early post-Aśokan India." Sacred Biography in the Buddhist Traditions of South and Southeast Asia. Ed. Juliane Schober. Honolulu: University of Hawai'i Press. Pp. 160-192. (magasins)

Wang, Yi-t'ung (tr.)(1984): A Record of Buddhist Monasteries in Lo-Yang, by Yang Hsüan-chich. Princeton: Princeton University Press.

Wangchuk, Dorji (2007): The Resolve to Become a Buddha. A study of the bodhicitta concept in Indo-Tibetan Buddham. Tokyo: The International Institute for Buddhist Studies. (Studia Philologica Buddhica, Monograph Series, 23.) 
Warder, A. K. (1980): Indian Buddhism. Second revised edition. Delhi etc.: Motilal Banarsidass.

Watters, Thomas (1904-05): On Yuan Chwang's Travels in India (A.D. 629-645). London: Royal Asiatic Society. Reprint : Munshiram Manoharlal, New Delhi, 1973.

White, David Gordon (1996): The Alchemical Body. Siddha traditions in medieval India. Chicago \& London: University of Chicago Press.

White, David Gordon (2005): Review of Davidson, 2002. Journal of the International Association of Tibetan Studies 1, 1-11.

White, David Gordon (2009): Sinister Yogis. Chicago \& London: The University of Chicago Press.

Whitney, Elspeth (1990): Paradise Restored: The Mechanical Arts from Antiquity through the Thirteenth Century. Philadelphia: American Philosophical Society. (Transactions of the American Philosophical Society, vol. 80 part 1.)

Widmer, Caroline (2008): "Reflexion religiöser Differenz und die Darstellung des 'anderen' im buddhistischen Lehrgespräch, ein Arbeitsbericht." AS 62(1), 425-446.

Wiles, Royce (2006): “The dating of the Jaina councils: do scholarly presentations reflect the traditional sources?" Studies in Jaina History and Culture: Diputes and dialogues. Ed. Peter Flügel. London \& New York: Routledge. Pp. 61-85.

Willemen, Charles; Dessein, Bart \& Cox, Collett (1998): Sarvāstivāda Buddhist Scholasticism. Leiden etc.: Brill. (Handbook of Oriental Studies, 2/11.)

Williams, R. (1963): Jaina Yoga. A survey of the mediaeval Śrāvakācāras. London etc.: Oxford University Press. (London Oriental Series, 14.)

Willis, Michael (2004): "The archaeology and politics of time." The Vākātaka Heritage. Indian culture at the crossroads. Ed. Hans T. Bakker. Groningen: Egbert Forsten. (Gonda Indological Studies, 13.)

Willis, Michael (2009): The Archaeology of Hindu Ritual. Temples and the Establishment of the Gods. Cambridge University Press.

Wirth, Gerhard \& Hinüber, Oskar von (1985): Arrian: Der Alexanderzug, Indische Geschichte. Griechisch und deutsch, herausgegeben und übersetzt. Munich - Zurich: Artemis. (Sammlung Tusculum.)

Witzel, Michael (1981 \& 1982): "Materialien zu den vedischen Schulen, 1 : Über die Caraka-Śākhā." StII 7, 109-132 \& 8/9, 171-240.

Witzel, Michael (1985): "Regionale und überregionale Faktoren in der Entwicklung vedischer Brahmanengruppen im Mittelalter (Materialien zu den vedischen Schulen, 5)." Regionale Tradition in Südasien. Hrsg. Hermann Kulke und Dietmar Rothermund. Wiesbaden: Franz Steiner. (Beiträge zur Südasienforschung, Südasien-Institut, Universität Heidelberg, 104.) Pp. 37-76.

Witzel, Michael (1987): "On the localisation of Vedic texts and schools (Materials on Vedic Śākhās, 7)." India and the Ancient World. History, trade and culture before A.D. 650. Ed. Gilbert Pollet. Leuven: Departement Oriëntalistiek. (Orientalia Lovanensia, Analecta, 25.) Pp. 173-213. 
Witzel, Michael (1989): “Tracing the Vedic dialects." Dialectes dans les littératures indo-aryennes. Ed. Colette Caillat. Paris: Édition-Diffusion de Boccard. (Publications de $1^{\prime}$ Institut de Civilisation Indienne, Série in- $8^{\circ}$, Fascicule 55.) Pp. 97-265.

Witzel, Michael (1990): "Notes on Vedic dialects (1)." Zinbun 25, 31-70.

Witzel, Michael (1994): “The Brahmins of Kashmir." In : A Study of the Nillamata. Aspects of Hinduism in ancient Kashmir. Ed. Yasuke Ikari. Kyoto: Institute for Research in Humanities, Kyoto University. Pp. 237294.

Witzel, Michael (1995): "Early Sanskritization: Origins and development of the Kuru state." Electronic Journal of Vedic Studies (EJVS) 1(4), 1-26. (http://www.ejvs.laurasianacademy.com/issues.html) (Cp. Witzel, 1997b.)

Witzel, Michael (1997): "The development of the Vedic canon and its schools: The social and political milieu. (Materials on Vedic Śākhās, 8)." = Witzel, 1997a: 257-345.

Witzel, Michael (ed.)(1997a): Inside the Texts, Beyond the Texts: New approaches to the study of the Vedas. Cambridge: Department of Sanskrit and Indian Studies, Harvard University. Distributed by South Asia Books, Columbia, Mo. (Harvard Oriental Series, Opera Minora, 2.)

Witzel, Michael (ed.)(1997b): "Early Sanskritization: origins and development of the Kuru state." Recht, Staat und Verwaltung im klassischen Indien / The State, the Law, and Administration in Classical India. Ed. Bernhard Kölver. München: R. Oldenbourg. (Schriften des Historischen Kollegs, Kolloquien 30.) Pp. 27-52.

Witzel, Michael (2003): Das alte Indien. München: C. H. Beck.

Witzel, Michael (2006): "Brahmanical reactions to foreign influences and to social and religious change." Between the Empires. Society in India 300 $B C E$ to 400 CE. Ed. Patrick Olivelle. Oxford University Press. Pp. 457499.

Wojtilla, Gyula (2000): “Did the Indo-Greeks occupy Pātaliputra?” Acta Antiqua Academiae Scientiarum Hungaricae 40, 495-504.

Wojtilla, Gyula (2006): History of Krșiśastra. Wiesbaden: Harrassowitz. (Beiträge zur Kenntnis südasiatischer Sprachen und Literaturen, 14.)

Wrangham, Richard (2009): Catching Fire. How Cooking Made Us Human. New York: Basic Books.

Wynne, Alexander (2007): The Origin of Buddhist Meditation. London \& New York: Routledge.

Xinru Liu (1988): Ancient India and Ancient China. Trade and religious exchanges $A D$ 1-600. Delhi etc.: Oxford University Press.

Yano, Michio (1987): "The Hsiu-yao Ching and its Sanskrit sources." History of Oriental Astronomy. Ed. G. Swarup, A. K. Bag, K. S. Shukla. Cambridge etc.: Cambridge University Press. Pp. 125-134.

Yano, Michio (2005): "Medicine and divination in India." East Asian Science, Technology, and Medicine 24, 44-61.

Zimmermann, Michael (2006): "Only a fool becomes a king: Buddhist stances on punishment." Buddhism and Violence. Ed. Michael Zimmermann. Lumbini: Lumbini International Research Institute. (LIRI Seminar Proceedings Series, 2.) Pp. 213-242. 
Zin, Monika (forthcoming): "Brahmanische Asketengräber.” Festschrift Schlingloff.

Zin, Monika \& Schlingloff, Dieter (2007): Samsāracakra. Das Rad der Wiedergeburten in der indischen Überlieferung. Düsseldorf: EKO-Haus der Japanischen Kultur. (Buddhismus-Studien / Buddhist Studies, 6.) 
Abbreviations:

Abhidh-k-bh(P) Vasubandhu, Abhidharmakośabhāṣya, ed. P. Pradhan, rev. 2nd ed. Aruna Haldar, Patna 1975 (TSWS 8)

Abhidh-k(VP) Vasubandhu, Abhidharmakośa, traduit et annoté par Louis de La Vallée Poussin, 6 vols., Paris 1923-1931

ABORI

AN

Apte

AS

ASS

Āyār

BaudhŚS

BCE

BEFEO

BEI

BHSD

BORI

BSOAS

BSR

BST

Buddhac

CE

ChānUp

CII

$\operatorname{Divy}(\mathrm{V})$

DN

EĀc

EDS

EpInd

ER

GobhGS

HBI

HIL

HistDh

Hôbôgirin

HOS
Annals of the Bhandarkar Oriental Research Institute Anguttara Nikāya

V. S. Apte, Sanskrit-English Dictionary, 3 vols., Poona 1957-1959

Asiatische Studien, Études Asiatiques, Bern

Ānandāśrama Sanskrit Series, Poona

Āyāraṃga

Baudhāyana Śrautasūtra

before the Common Era

Bulletin de l'École Française d'Extrême-Orient, Paris

Bulletin d'Études Indiennes, Paris

Franklin Edgerton, Buddhist Hybrid Sanskrit Grammar and

Dictionary, vol. 2: Dictionary, New Haven 1953

Bhandarkar Oriental Research Institute, Poona

Bulletin of the School of Oriental and African Studies

Buddhist Studies Review

Buddhist Sanskrit Texts, Darbhanga

Aśvaghoșa, Buddhacarita, ed. and transl. E. H. Johnston,

Calcutta 1935

Common Era

Chāndogya Upanișad

Corpus Inscriptionum Indicarum

Divyāvadāna, ed. P. L. Vaidya, Darbhanga 1959 (BST 20)

Dīghanikāya, ed. T. W. Rhys Davids, J. E. Carpenter, 3 vols. 1890-1911 (PTS)

Ekottara Āgama (TI 125)

An Encyclopaedic Dictionary of Sanskrit on Historical

Principles, ed. A. M. Ghatage etc., vol. 1 ff., Poona, 1976 ff.

Epigraphia Indica

The Encyclopedia of Religion, éd. Mircea Eliade, New

York: Macmillan; London: Collier Macmillan, 1987, 16 vols.

Gobhila Grhyasūtra

Étienne Lamotte, Histoire du bouddhisme indien, des origines à l'ère Śaka, Louvain 1958

A History of Indian Literature, ed. J. Gonda, Wiesbaden $1973 \mathrm{ff}$.

See Kane, HistDh

Hôbôgirin, Dictionaire encyclopédique du bouddhisme

d'après les sources chinoises et japonaises, éd. S. Lévi, J.

Takakusu, P. Demiéville, Fasc. 1ff., Tôkyô, Paris 1929 ff.

Harvard Oriental Series, Cambridge Mass. 
IIJ

IndTib

JA

Jā

JAOS

JIABS

JIP

$\mathrm{Jm}$

$\operatorname{Jm}(\mathrm{H})$

$\operatorname{Jm}(\mathrm{V})$

JOIB

JPTS

JRAS

Kane, HistDh

KāthS

K1Schr

Lal

$\mathrm{Lal}(\mathrm{V})$

$M \bar{A}^{c}$

Mahā-bh

MaitS

Manu

Mhbh

MīS

MMK

$\mathrm{MN}$

Mvu

MW

NDPS

Nir
Indo-Iranian Journal

Indica et Tibetica, Bonn, Marburg

Journal Asiatique

Jātaka, together with its Commentary, ed. V. Fausbøll, 6

vols., London 1877-1896; vol. 7 (Index, D. Andersen), 1897

Journal of the American Oriental Society

Journal of the International Association of Buddhist Studies

Journal of Indian Philosophy

Āryaśūra, The Jātaka-Mālā or Bodhisattvāvadāna-Mālā, ed. Hendrik Kern, Boston 1891 (HOS 1)

Āryaśūra, Jātakamālā, ed. A. Hanisch, Marburg 2005 (IndTib 43/1)

Āryaśūra, Jātakamālā, ed. P. L. Vaidya, Darbhanga 1959 (BST 21)

Journal of the Oriental Institute, Baroda

Journal of the Pali Text Society

Journal of the Royal Asiatic Society of Great Britain and Ireland, London

Pandurang Vaman Kane, History of Dharmaśāstra, second edition, Poona: Bhandarkar Oriental Research Institute, 5 vols., 1968-1977

Kāthaka Samhitā

Kleine Schriften [in the series of the Glasenapp-Stiftung],

Wiesbaden, Stuttgart

Lalitavistara, ed. S. Lefmann, 2 vols., Halle 1902-1908

Lalitavistara, ed. P. L. Vaidya, Darbhanga 1958 (BST 1)

Madhyama Āgama (TI 26)

Patañjali, (Vyākaraṇa-)Mahābhāṣya, ed. F. Kielhorn, Bombay 1880-1885

Maitrāyan̄i Samhitā

Mānava Dharmaśāstra, ed. Olivelle, 2005

Mahābhārata, crit. ed. V. S. Sukthankar u.a., Poona 1933-66 (BORI)

1) Mīmāmsā Sūtra. Edited, with Kumārila Bhatta's

Tantravārttika and Śabara's Bhāṣya, by Pt. Ganeśsasāstrī

Joś1. Pādas 1.2 - 2.1. Poona: Ānandāśrama. 1981. 2) Sāarara-

Bhāṣya. Translated into English by Ganganatha Jha. Vol. I.

Baroda: Oriental Institute. 1973.

Mūlamadhyamakakārikā

Majjhima-Nikāya, ed. V. Trenckner, R. Chalmers, 3 vols., London 1888-1899 (PTS)

Mahāvastu-Avadāna, ed. Émile Senart, 3 vols., Paris 18821897

Monier Monier-Williams, A Sanskrit-English Dictionary, Oxford 1899

Nālandā Devanāgarī Pāli Series, Nālandā

1) Jāska's Nirukta sammt den Nighaṇtavas, herausgegeben und erläutert von Rudolph Roth. Göttingen 1852. Reprint 
ÖAW

OLZ

$\mathrm{P}$.

Pațis-a

PTS

PTSD

Rām

RHR

RV

SĀ

Saddharmap(V)

Saund

SAWW

SBB

ŚIV

SN

ŚPaBr

StII

Sūtrāl(B)

Sūy

TaitS

TI

TSWS

Utt

Vibh-a
Darmstadt: Wissenschaftliche Buchgesellschaft. 1976. 2)

The Nighantu and the Nirukta. Edited and translated by

Lakshman Sarup. Reprint Delhi: Motilal Banarsidass. 1967.

Österreichische Akademie der Wissenschaften, Wien

Orientalistische Literaturzeitung

Pāninian sūtra

Saddhammappakāsinī, commentary on the

Pațisambhidāmagga. Edited by C. V. Joshi. London:

Routledge \& Kegan Paul. 1979. 3 vols. (Pali Text Society

Text Series, 103-105.)

Pali Text Society, London

The Pali Text Society's Pali-English Dictionary, ed. T.W.

Rhys Davids, W. Stede, London 1921

Rāmāyaṇa, crit. ed. G. H. Bhatt a.o., Baroda 1960-75

Revue de l'Histoire des Religions, Paris

Rgveda-samhitā

Samyuktāgama (= TI 99)

Saddharmapuṇụarīka Sūtra, ed. P. L. Vaidya, Darbhanga 1960 (BST 6)

Aśvaghoșa, Saundarananda, ed. and transl. E. H. Johnston, Oxford 1928-32

Sitzungsberichte der Akademie der Wissenschaften in Wien, Phil.-hist. Kl., Wien

Sacred Books of the Buddhists Series, London

1) Ślokavārttika of Śrī Kumārila Bhatta, with the

commentary Nyāyaratnākara of Śrī Pằrthsārthi Miśra.

Edited and revised by Swāmī Dvārikādāsa Śāstrī. Varanasi:

Ratna Publications. 1978. (Ratnabharati Series, 3.) 2)

Slokavartika, translated ... with extracts from the

commentaries 'Kasika' of Sucarita Misra and

'Nyayaratnakara' of Partha Sarthi Misra, by Ganga Nath

Jha. Second edition. Delhi: Sri Satguru Publications. 1983.

(Sri Garib Das Oriental Series, 8.)

Samyutta-Nikāya, ed. L. Feer, 5 vols., London 1884-1898

(PTS), vol. 6 (Indexes by C.A.F. Rhys Davids), London

1904 (PTS)

Śatapatha Brāhmana

Studien zur Indologie und Iranistik

Asañga, Mahāyānasūtrālañkāra, ed. S. Bagchi, Darbhanga 1970 (BST 13)

Sūyagaḍamgasutta $=$ Sūtrakṛtānga Sūtra

Taittirīya Saṃitā

Taishō Shinshū Daizōkyō or Taishō Issaikyō, 100 vols., Tōkyō 1924 ff.

Tibetan Sanskrit Works Series, Patna

Uttarajjhayaṇa / Uttarajjhāyā

Buddhaghosa, Sammohavinodanī, Vibhangga-ațthakathā, ed.

A. P. Buddhadatta, London 1923 (PTS) 
Vin Vinayapitaka, ed. H. Oldenberg, 5 vols., London 1879-1883 (PTS)

Vism Buddhaghosa, Visuddhimagga, ed. H. C. Warren, revised by armananda Kosambi, Cambridge, Mass. 1950 (HOS 41) Viyāhapaṇnatisuttam. Edited by Pt. Bechardas J. Doshi (for part II assisted by Pt. Amritlal Mohanlal Bhojak). Bombay: Shrī Mahāvīra Jaina Vidyālaya. 1974-78. 2 parts. (JainaĀgama-Series No. 4.)

Viy (ed. Nathamal) Anga Suttāni, II: Bhagawai Viāhapannatti. Ed. Muni Nathamal. Ladnun: Jain Viswa Bhārati. V.S. 2031

Vkp

VWC Bhartrhari, Vākyapadīya, ed. W. Rau, Wiesbaden 1977

WZKS A Vedic Word Concordance, by Vishva Bandhu, 5 vols., Hoshiarpur: V.V.R. Institute, 1955-1965

WZKSO Wiener Zeitschrift für die Kunde Südasiens ZDMG Wiener Zeitschrift für die Kunde Süd- und Ostasiens Zeitschrift der Deutschen Morgenländischen Gesellschaft 
$\underline{\text { Index }}$

Abhayadatta

Abhayakīrti

Abhidharma

Abhidharmakośa Bhāṣya

Abhidharma-vibhāṣā-śāstra

Abhijñānaśākuntala

abhișeka

Achaemenid empire

Ādi Purāṇa

Advaita

Afghanistan

Aggañ̃a Sutta

Aghori

Agnihotra / agnihotra

agrahāra / agrahāras

āhitāgni

Ahorātravrata

Aitareya Brāhmaṇa

Ajātaśatru

Ājīvika / ājīvika

$\bar{A}$ jīvikism

Akbar

Alandi

Alexander

$\bar{A} \mathrm{ma}$

Ambașṭhas

Ambattha

Ambattha Sutta

Amoghavajra

Ānanda

Ānandacandra

Anāthapiṇ̣ika

Āndhra

anekāntavāda

Angavijjā

Angkor / Anjkor / Ankor

Anguttara Nikāya

Añkor Thom

Ańkor Vat

Annambhatṭa

antyești

Anuśāsanaparvan

Apaṇnaka Sutta

Āpastamba Dharmasūtra

Aramaic 
Āratța / Araț̣a / Arātṭa

archaeological evidence

Ardha-Māgadhī

Ardhaphālaka

Arrian

ärșa

artha

Arthaśāstra

Āryadeva

Āryaśūra

Āryāvarta

Asanga

asceticism

Asita

Aśoka

āśrama / āśramas

āśrama-vihāra

Assalāyana Sutta

Aștāadhyāȳ

astrology

astronomy

Aśvaghoṣa

Āśvalāyana

Atharvaveda

Atharvavedaparisisista

Ātmatattvaviveka

Aupamanyava

Aupapātika Sūtra

Avalokiteśvara

Āvassaya Nijjutti / Āvaśyakaniryukti

Avidūrenidāna

āyāgapața

Ayodhyā

ayurveda

Bactria

bāhīka

bāhlikka

Baktra

bālhikka

Bali

bali

Bamiyan / Bāmiyāna

Bāṇa

Baudhāyana Dharmasūtra

Baudhāyana-pitrmedha-sūtra

Baudhāyana Śrautasūtra

Bhagavadgìtā

Bhāgavata Purāna 
Bharadvāja

Bhāradvāja-pitrmedha-sūtra

Bharata

Bhartrhari

bhattāàraka

Bhāviveka

Bhavya

Bhūmicchidrāpidhāna

bhūmidāna

Bijjana

Bimbisāra

Bindusāra

Black Yajurveda

bodhicitta

Bodhisattva

Bodhisattvabhūmi

Bodhisattva-yāna

Borneo

brahmadeya

brahmadeyāgrahāra

brahmadeyya

Brahmajāla Sutta

brāhmaṇa-gahapati

brāhmaña-gāma

brāhmaṇaśramaṇanyāya

Brāhmī

Buddha

Buddhacarita

Buddhaghosa

Burma

$\mathrm{Bu}$ ston

caitya

Cakkavatti-Sīhanāda Sutta

cakravartin

Cambodia

Cānakya

candūala

Candragomin

Candragupta

Candragupta II

Candrakīrti

Candraprabha Jātaka

Cāndra Vyākaraña

Capella

Caraka-samhitā

caru / caruka

caste-classes

Catuhśataka 
Caturasititisiddhapravrtti

Caulukya

Chāndogya Upaniṣad

Ch'ang-an

Cheya Suttas

China

Chinese

Coda

Cola

correspondence principle

court

Damila

daṇ̂añiti

Daśabala

Daśaratha

Devadaha Sutta

Devanandin

Devapāla

Devapāladeva

Devatāvimarśastuti

Dharma / dharma

dharmakāya

Dharma-king

Dharmakīrti

Dharmapāla

Dharmarāja I

dharmaśarīra

dharmaskandha

Dharmaśokarāja

Dharmasūtra / Dharmasūtras

Dharwar

Dhvanyālokalocana

dhyāna

dhyānayoga

Digambara

Dīgha Nikāya

Dignāga

Digvarman

Dīpikā

Divākarabhatṭa

Divākaramitra

Dīvasāgarapannatti

Divyāvadāna

Dravidas

Dravidian

Dusyanta

Duț̣̂hagāman̄ī / Duțthagāmaṇi

dvija 
edūka

ekaghana

Elāra

Ennin

Erigena

Faxian

framing

Fūdō

funerary practices

gahapati

ganadhara

Gandatindu Jātaka

Gạ̣davyūha

Gandhāra

Gāndhāra

Gāndhārī

gāndhārī vidyā

Gañgā

Gautama Dharmasūtra

Ghotamukha Sutta

Girnār

Gobhila Gṛhyasūtra

Gopathabrāhmaṇa

grāmakāma

Greater Gandhāra

Greater Magadha

Greece

Greek / Greeks

grhapati

Gṛhyasūtra / Gṛhyasūtras

Gujarat

Gunamati

Gupta

Haribhadra

Harinegamesi

Harivamśa

Harșacarita

Harșavardhana

Harsavarman III

Hāthīgumphā Inscription

havana

Helārāja

Hemacandra

hermitage / hermitages

hetu

hetuśāstra

Hetuvidyā

Hinayana Buddhism 
Hrdaya treatises

Hybrid Sanskrit

inactive self

Indica

Indo-Aryan

Indo-Greek / Indo-Greeks

Indo-Scythians

Indravarman I

Iran

Áśānavarman I

Islam

Jaiminīya Brāhmana

Jaina / Jainas

Jainism

Jalalabad

Jāliya Sutta

Jamāli

Jambuddīvapannatti

Jānaśruti Pautrāyaṇa

Japan

Jātaka

Jātakamālā

Java

Jayavarman

Jayavarman II

Jayavarman V

Jayavarman VII

Jayavarman VIII

Jetavana

Jina

Jinadāsa

Jinasena

Jīvājīvābhigama

Jñānadeva

Junāgaḍh / Junagadh

jyotih

jyotihśāstra

Kālacakra Tantra

Kalhana

Kālidāsa

Kalinga

Kaliyugaparikathā

Kalpanāmaṇuitikā Drṣṭ̂̄ntapañkti

kāma

Kāmandaki

Kāmasūtra

Kāmbojas

Kanauj 
Kandahar

Kandaraka Sutta

Kandy

Kanișka

Kanva

Kanyākubja

Kappa Sutta

Karle

karma

Karmavibhañgopadeśa

karmic retribution

Karnataka

Kashmir

Kāśikā

Kassapa Sìhanāda Sutta

Kaśyapa

Kāśyapaśilpa

Katha Upaniṣad

Kaumāralāta

Kauśika

Kaușitaka Gṛhyasūtra

Kautilya

Kautsa

Kāvyālaṃkāra

Kāvyamìmāmsā

Keniya

Kevaddha Sutta

Khadgodyama

Khandila

Khāravela

Kharoșthī

Khmer

king / King

Kīrtipaṇuita

Korea

Kosala

Krsna

Krtanagara

Ksatrapa

Kṣatriya

Kukkuṭapāda

Kumāralāta

Kumārapāla

Kumārapālapratibodha

Kumārila

Kumudacandra

Kuru state

Kuṣāna 
Kuśinagara

Kütadanta Sutta

Lakṣmaṇa

Lalitavistara

Làikāvatāra Sūtra

Laws of Manu

legitimate / legitimation

Letter to King Gautamīputra

Life of the Buddha

Life of Vasubandhu

Lokaneyyapakarana

Lumbin̄̄ / Lummini

Madhyamakahṛdayakārikā

Mādhyamika

Madhyāntavibhāga-kārikā Bhāṣya

Madhyāntavibhāga Śāstra

Madhyāntavibhāga-sūtra Bhāṣya

Madhya Pradesh

Madra

Magadha

Māgadhī

Mahābhārata

Mahābhāṣya

Mahābhāṣadīpikā

Mahābodhi

Mahāgovinda Sutta

Mahākāśyapa

Mahāksatrapa

Mahāli Sutta

Mahāpadāna Sutta

Mahāparinibbāna Sutta

Mahāparinirvāna Sūtra

Mahāprajñāpāramitā Śāstra

Mahāsāmghika

Mahāsudarśana

Mahāvamsa

Mahāvastu

Mahāvīra

mahāyajña

Mahāyāna / Mahāyānism

Mahāyānasañgraha

Mahāyānasūtrālaṃkāra

Maitrāyaṇ̄

Maitreya

Maitreya samiti

Majjhima Nikāya

Mallas

Mallișena-Maladhārideva 
Mānava Dharmaśāstra

Mañjuśrī

mantra

Mantramārga

Manusmrti

Māra

Mātañga

Mātaìgī Sūtra

mathematics

Mathurā / Mathura

Mātṛceța

Maurya

Mazdeism

medicine

Megasthenes

Menander

Merutunga

Middle Indic

Milinda

Milinda-pañha

Mīmāmsā

Mīmāmsakas

Mìmāmsā Sūtra

Mohavicchedan̄̄

monasteries

Mūgapakkha Jātaka

Mughal

Mūlācāra

Mūlamadhyamakakārikā

Mūlasarvāstivāda Vinaya

Mūlasarvāstivādin

Mūlavarman

Munda

Mundy

muni

Muslim

Nagarahāra

Nāgārjuna

Nāgasena

Nahapāna

Nālandā

Namisādhu

Nānāghāt

Nanda

Nandī-cūrṇi

Nāropa

Nāsatyas

Nāsik 
Nātaputta

Nepal

Newar Buddhism

Nidānakathā

Nigantha

Nīlamatapurāna

Nimi

Nirukta

nìti

Nìtisāra

Nītivākyāmṛtam

numismatic evidence

Nyāya

Nyāyakusumacandra

Nyāyavārttika

Orissa

Ostler

Padmanābha

Pagan

Pahlava

Paiśācī

Pakistan

Pāla

Pallava

Pañcatantra

Pañcavimiśa Brāhmaṇa

Pāṇ̣̂ya

Pānini

Paramārtha

Pāraskara Gṛhyasūtra

parihāra

parinirvāna

parivrājaka

Parthians

Pasenadi

Paspaśāhnika

Pātaliputra

Patañjali

Persepoles

Persians

philosopher

philosophy

physician

Pollock

Prabandhacintāmaṇi

Prabandhakośa

Prabhācandra

Prajñāsataka 
Prajñāśataka-nāma-prakarana prākrta / Prakrit

Prasannapadā

pratītyasamutpāda

pratyekabuddha

Precious Garland

primary religions

pudgala

Punjab

Purāna

Pūrana

Purohita / purohita

Pusyagupta

Puṣkarasārin

Questions of King Milinda

Rādhāsvāmin

Raikva

rājadāya

Rājadharma-nyāya-śāstra

Rājādhirāja II

Rājagrha

rājaguru

rājanīti

Rājanya

Rājaśekhara

Rājasūya

Rājatarañin̄ī

Rāma

Rāmāyaṇa

Rāṣtrakūṭa

Ratnadeva

ratna-traya

Ratnāvalī

rebirth

relic

ritual

Rsabha

Rudradāman

Rudrata

rūpakāya

Śābara Bhāsya

sacrifice / sacrifices

Saddanīti

Saddharmapundarīka Sūtra

Sagāthaka

Śaiva / Śaivism

Śakas

Śakuntalā 
sallekhanā

samādhi

Samādhirāja Sūtra

Sāmañ̃naphala Sutta

Samantabhadra

sāṃrahaṇ̄

Sāṃhya

Sammohavinodin̄̄

saṃnyāsin

Śankara

Śaṅkaranandana

Śankkarasvāmin

Śāikhāyana Gṛhyasūtra

Sanskrit

Sanskrit cosmopolis

Śātiparvan

Sarasvatī

Śārdūlakarṇāvadāna

Sāriputra

Sarvadurgatipariśodhana Tantra

Sarvajñamaheśvarastotra

Sarvārthasiddhi

Sarvāstivāda

Sarvāstivādin

Śatadru

Sātakarni

Sātakarṇi Gautamīputra

Śatapatha Brāhmaṇa

Sātavāhana

Satyāṣāệha Śrautasūtra

Saundarananda

Sautrāntika

Scythian

secondary religions

Sela-sutta

Seleucid

Seleucus

Siam

siddha

Śikhālaka Sūtra

Śīlabhadra

Singālovāda Sutta

Sìtā

Śiva

Śivakaivalya

Śivasoma

Skandagupta

Ślokavārttika 
Smrtyarthasāra

Somadeva Sūri

Somaprabhasūri

Sonadanda Sutta

Southeast Asia

spells

Śramanas

Śramanas and Brahmins

śrāvakācāra

Śrāvakayāna

Sravana Belgola

Śrāvastī

Śrenika Bimbisāra

Śrenya

Śrīcandra

Sri Lanka / Śrī Lankā

Sthiramati

stūpa

Śuddhodana

Śūdra

Sukothai

Śungas

Sūryavarman I

Sutasoma Jātaka

Sūtrālamkāra

Suvarnabhāsottama

Suvarnaprabhāsa Sūtra

Suviśākha

Sūyagada

svadharma

Śvetāmbara

tailadroṇi

Taittirīya Saṃhitā

Tamil

Tamil Nadu

Tang

Tantra

Tantrākhyāyika

Tantravārttika

Tāranātha

Tathāgata

Tattvārthādhigama Bhāṣya

Tattvārtha Sūtra

Taxila

Temīya

Thailand

Thânaniga

Thar desert 
Theragāth $\bar{a}$

Theravāda

Tibet

tìrthankara

Tissadatta

Triśankku

Trișaștiśalākāpuruṣacaritra

trivarga

Tuṣāspha

Udayana

Udbhatasiddhasvāmin

Uddyotana

Udyogaparvan

Ugrapariprcchā

Universal Monarch

Upāṅga

upāsaka

upāsikā

Upaveda

urbanization

Vaidalyaprakaraṇa

Vaikhānasa Gṛhyasūtra

Vaikhānasa Śrautasūtra

Vaiśeșika

Vaiṣnava / Vaiṣnavism

vaiśvadeva

Vaiśya

Vajrasūci

Vakkali Sutta

Vākyapadīya

Valabhī

Varāhamihira

varna

Varnārhavarnastotra

Varșākāra

Vasiștha Dharmasūtra

Vassakāra

Vasubandhu

Vat-Sithor

Vatțagāman̄ī Abhaya

Vattakera

Vavahāra Sutta

Vedānga

Vedānta

Veda-study / vedic study

Vedic

Venuvana

Vibhanga 
Vibhāsā

Vigrahapāla III

vihāra

Vijayavarman

Vikramāditya

Vikramaśîla

Vikramendravarman

Vinaya

Vinaya-pitaka

Vindhya

Vindhyavāsa

Viśeșastava

Viṣnu

Viṣnugupta

Viṣnu Purāna

Visuddhimagga

Viyāhapannati / Viyāhapannatti

Vrtti

Vrttikāragrantha

Vyākaraṇa-Mahābhāṣya

Vyavahārasūtra

Wheel

Wheel-Treasure

Xuanzang

Yādava Prakāśa

Yamunā

Yāpanīya

Yaśastilaka

Yāska

Yaśobhadrasūri

Yaśovarman

Yatidharmasamuccaya

Yavana

Yavanism

Yijing

Yoga

Yoga Bhāṣya

Yogācāra

yogācāra

Yogācārabhūmi / Yogācārabhūmiśāstra

Yogaśāstra

Yogasūtra

yogāvacara

yogin

Yuga

Yuktidīpikā

yūpa 